\title{
OLHARES DE EDUCADORES AMBIENTAIS PARA ESTUDOS DO MEIO E PERTENCIMENTO
}

\author{
SANDRA REGINA LESTINGE
}

Tese apresentada à Escola Superior de Agricultura "Luiz de Queiroz", Universidade de São Paulo, para obtenção do título de Doutor em Recursos Florestais, com opção em Conservação de Ecossistemas Florestais.

\author{
PIRA CICAB A \\ Estado de São Paulo - Brasil \\ Setembro - 2004
}




\title{
OLHARES DE EDUCADORES AMBIENTAIS PARA ESTUDOS DO MEIO E PERTENCIMENTO
}

\author{
SANDRA REGINA LESTINGE
}

Zootecnista

Orientador: Prof. Dr. MARCOS SORRENTINO

\begin{abstract}
Tese apresentada à Escola Superior de Agricultura "Luiz de Queiroz", Universidade de São Paulo, para obtenção do título de Doutor em Recursos Florestais, Área de Concentração com opção em Conservação de Ecossistemas Florestais.
\end{abstract}

PIRACICABA

Estado de São Paulo - Brasil

Setembro - 2004 
Dados Internacionais de Catalogação na Publicação (CIP)
DIVISÃO DE BIBLIOTECA E DOCUMENTAÇÃO - ESALQ/USP

Lestinge, Sandra Regina

Olhares de educadores ambientais para estudos do meio e pertencimento /

Sandra Regina Lestinge. - - Piracicaba, 2004.

247 p. : il.

Tese (Doutorado) - - Escola Superior de Agricultura Luiz de Queiroz, 2004.

Bibliografia.

1. Educação ambiental 2. Educação para cidadania 3. Ensino e aprendizagem 4. Meio ambiente - Educação 5. Percepção I. Título

CDD 333.707

"Permitida a cópia total ou parcial deste documento, desde que citada a fonte - O autor" 


\section{Montanhas e Vales}

No Amado acho as montanhas, os vales solitários, nemorosos.

As montanhas têm altura, são fartas, largas e formosas, cheias de encantos, com flores perfumadas.

O Amado é para mim essas montanhas.

Os vales solitários são quietos, amenos, frescos; dão sombra, e estão cheios de doces águas; com a variedade de seus arvoredos e o suave canto das aves, proporcionam alegria e deleite ao sentido; com a sua solidão e silêncio, oferecem refrigério e descanso.

Esses vales, eis o que é o meu Amado para mim.

\section{Diálogo}

Amada às criaturas:

ó bosques e espessuras, Plantadas pela mão do meu Amado!

Ó prado de verduras, De flores esmaltado, Dizei-me se por vós ele há passado!

Criaturas à Amada: Mil graças derramando, Passou por estes soutos com presteza, $E$, enquanto os ia olhando, Só com sua figura A todos revestiu de formosura.

San Juan de la Cruz (in: Sciadini, P.,1989) 


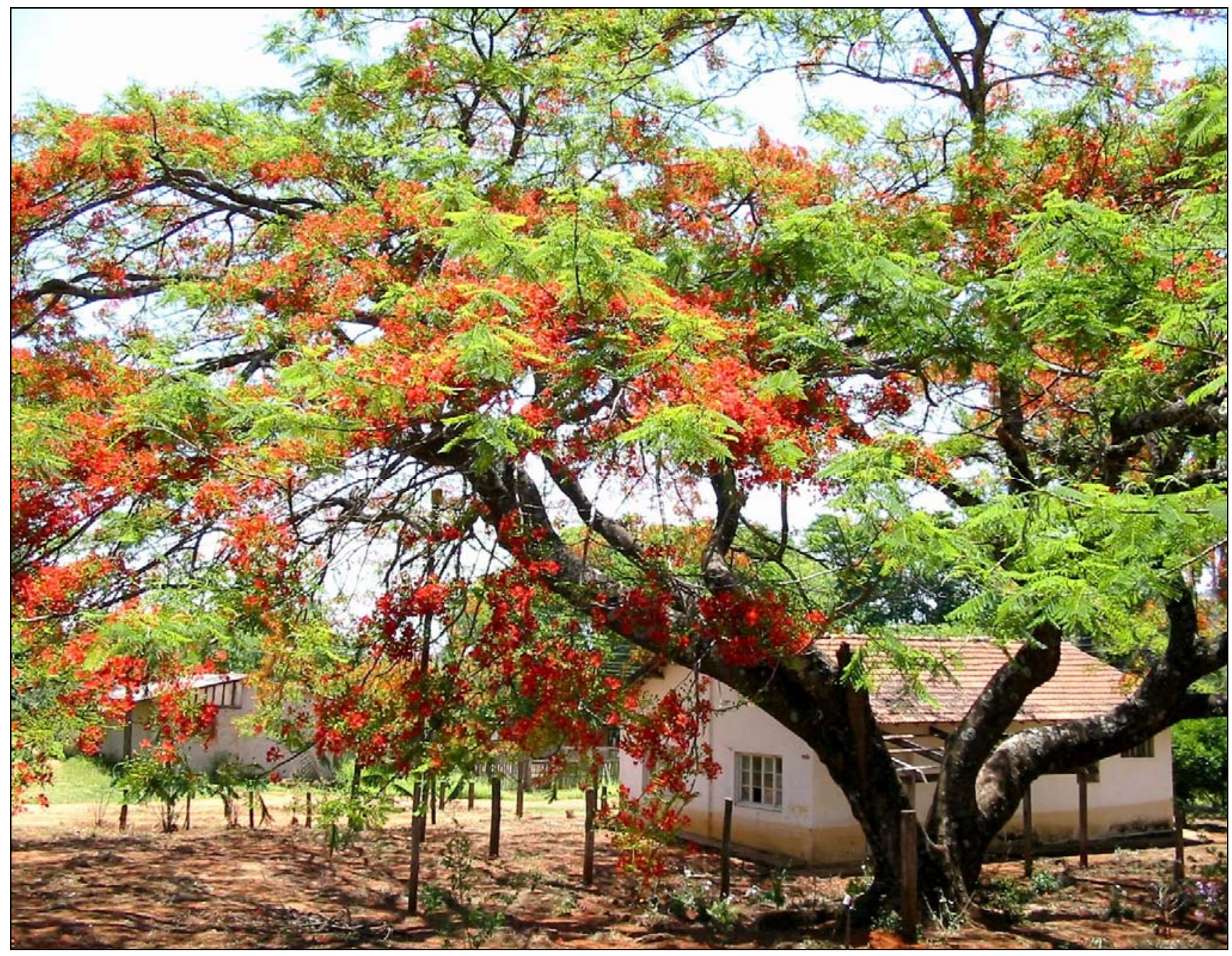

Flamboyant majestoso 


\section{AGRADECIMENTOS}

Agradecer, para mim, é dar graças, louvar o que me foi concedido, celebrando minha fé.

Assim, dou graças a tudo e a todos. Primeiramente, à minha mãe Odette e a meu pai, João, que deram luz à minha vida; e depois ao meu Daniel que, mesmo antes de nascer do meu ventre ou de aprender a caminhar, me impulsionou para frente, para outros aprendizados.

Agradeço aos meus queridos e fiéis amigos do Colégio Emilie de Villeneuve, Loly, Wilson, Patrizia, Hanny e Maísa, que acreditaram em mim e viajaram junto comigo nas idéias e também nos estudos do meio.

Agradeço a acolhida que tive na ESALQ, que desde o primeiro contato, através de um "sinal verde" do prof. Natal, conheci o prof. Marcos Sorrentino. Piracicaba também me acolheu, ingressei no mestrado e termino agora um doutorado. Aqui sempre tive as portas abertas e muitas oportunidades para crescer.

A todas as amigas da OCA, de todas as horas: Ana, Flávia e Cláudia. E aos estimados Cecéu e Alexandre. Ao Mário, em especial, pelo artigo do botânico Hoehne, e à Rita, pelo empréstimo do manual dos escoteiros do Velho Lobo.

Aos queridos amigos: João Hoeffel, Vânia, Gica e a meu irmão Roberto, obrigada pelo apoio constante e carinho.

Agradeço também a Silvia e Roberto que me ajudaram nos caminhos do "ser" e do "sentir" na dinâmica da vida.

Um agradecimento muito especial fica para todos os participantes do curso de especialização, com suas contribuições especialíssimas para este trabalho, principalmente aos que foram até o final da pesquisa: Costa, Fabíola e, à Eliane, obrigada também, por puxar a quadrilha, momento mágico de Itatinga. Agradeço ainda aos que cederam as fotos para este trabalho, lamento por omitir os créditos. 
Agradeço a CAPES, pela bolsa empréstimo de doutorado direto e a FAPESP, pelo auxílio à pesquisa.

Finalizando, agradeço aos professores que tenho como mestres - Eda Tassara, Carlos Rodrigues Brandão e Marcos Sorrentino - provas que são de coerência profícua entre falar, pensar e agir, trabalhando como cidadãos do mundo, para construção de sociedades mais justas e solidárias. 


\section{SUMÁRIO}

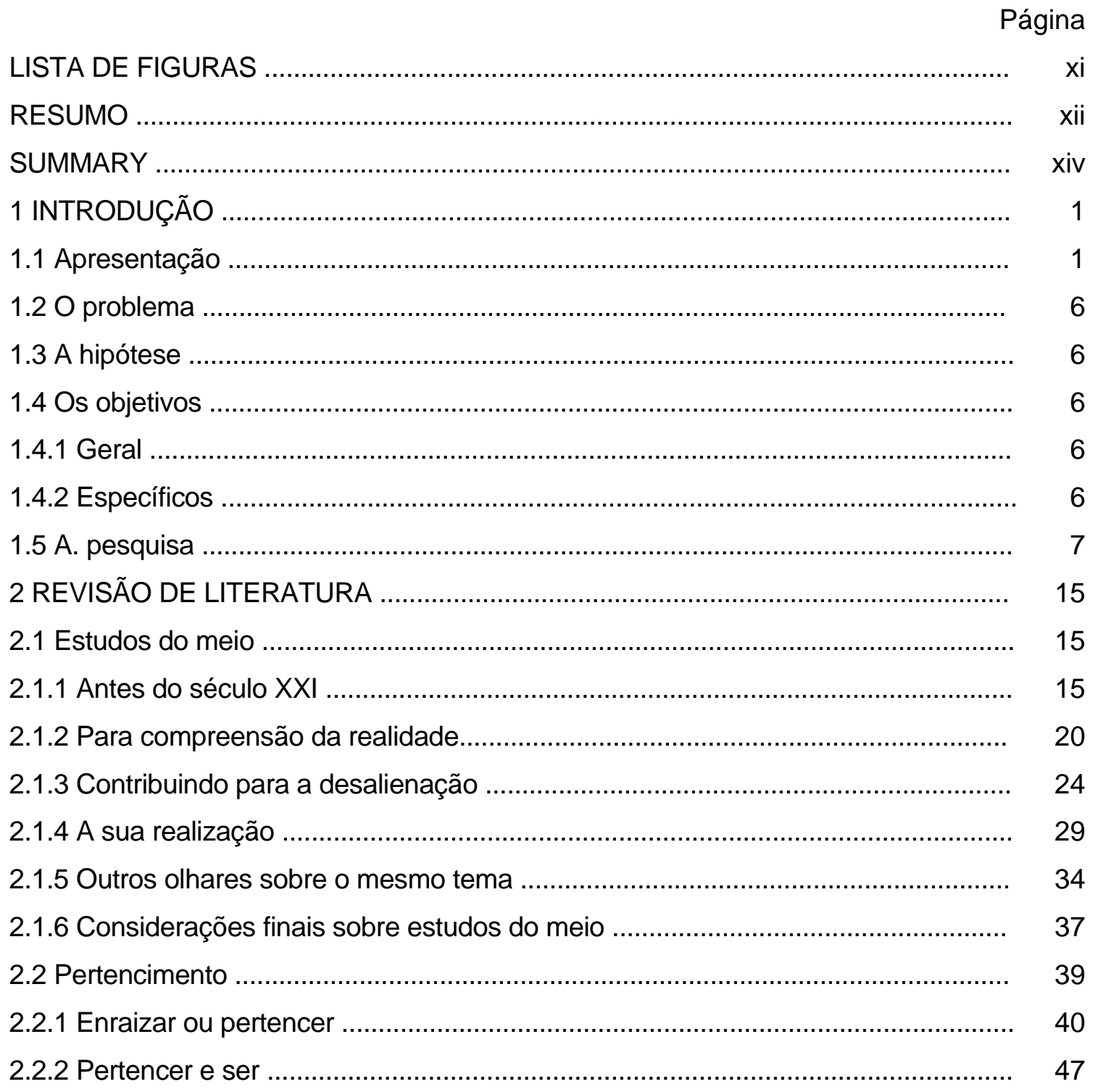


2.3 Olhares para a pesquisa qualitatitva

2.3.1 Pesquisa quantitativa ou pesquisa qualitativa 53

2.3.2 Pesquisa participante 55

2.3.3 Pesquisa-ação

2.3.4 Pesquisa etnográfica

2.3.5 Estudo de caso 59

3 METODOLOGIA

3.1 Breve memória de um curso piloto

3.1.1 O cenário

3.1.2 A proposta pedagógica

3.1.3 A estrutura

3.1.4 Perfil dos atores discentes

3.1.5 O primeiro encontro concentrado

3.1.6 Os outros encontros concentrados

3.1.7 Educação a distância

3.1.8 Aprendizagem na monitoria dos minicursos

3.1.9 O curso em cena

3.2 Ensinando a estudar o ambiente

3.2.1 "Re-conhecendo o meio ambiente" - uma retrospectiva

3.2.2 "Re-conhecendo o meio ambiente" - as decorrências

3.3 O trabalho de campo - coleta de dados

3.3.1 O trabalho de campo no $1^{\underline{0}}$ tempo

3.3.2 O trabalho de campo no $2^{\circ}$ tempo

3.3.3 O trabalho de campo no $3^{\circ}$ tempo

3.3.4 Os 3 olhares

4 RESULTADOS E DISCUSSÃO

4.1 Olhar vertical

4.1.1 "Ponto zero"

4.1.1.1 Estudo do meio 


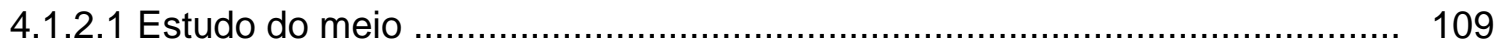

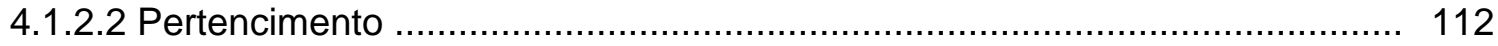

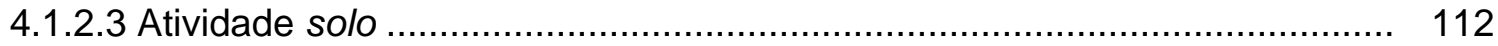

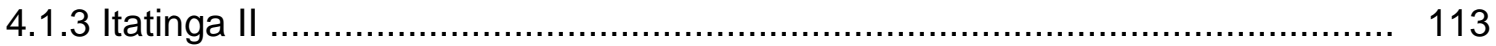

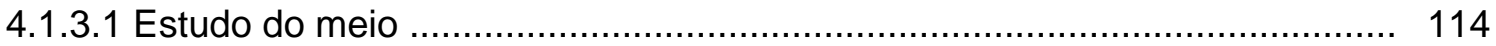

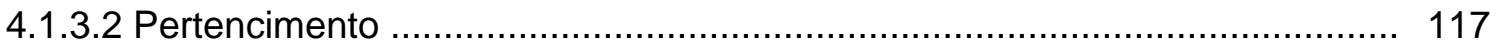

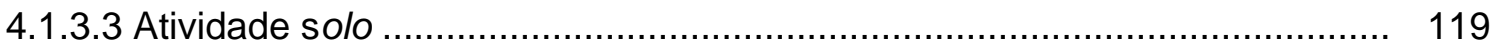

4.1.4 Projetos de intervenção ................................................................... 122

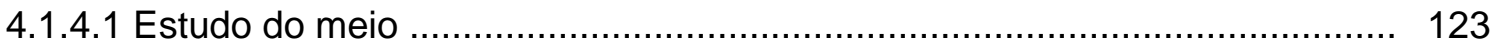

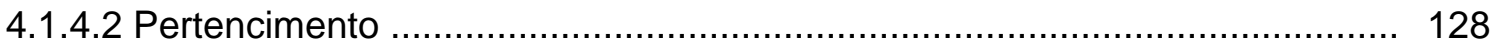

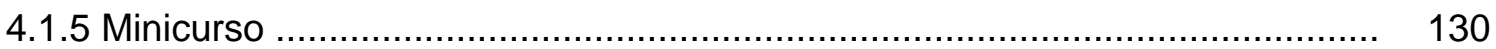

4.1.5.1 Estudo do meio ........................................................................... 130

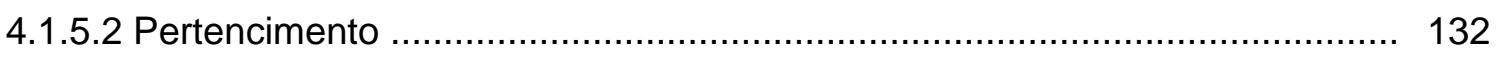

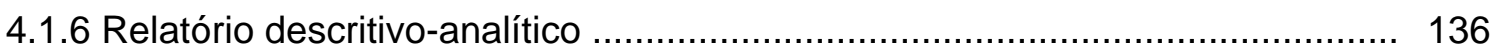

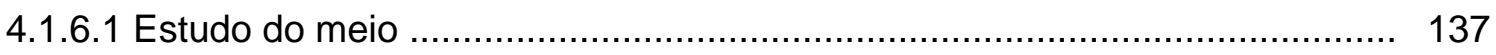

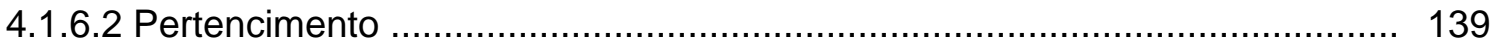

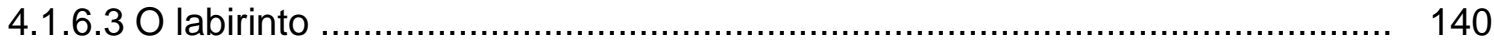

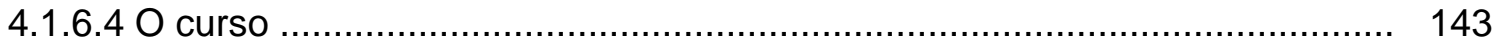

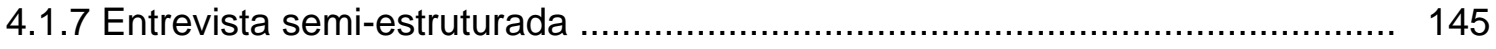

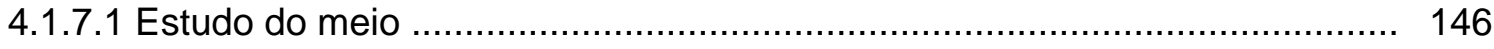

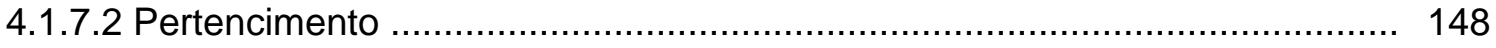

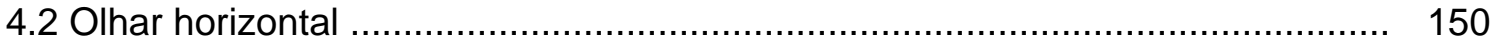

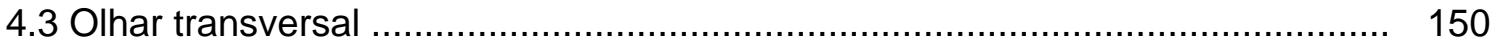

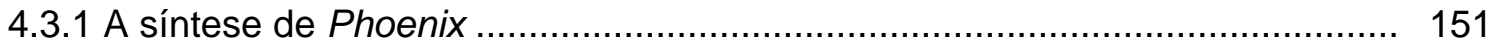

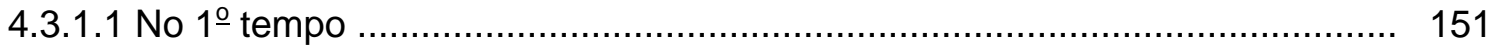

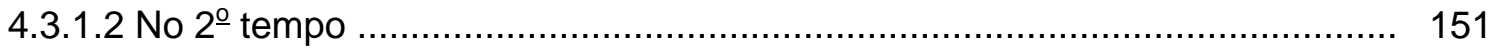

4.3.2 A síntese de Hercules ................................................................... 165

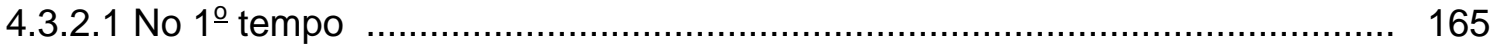

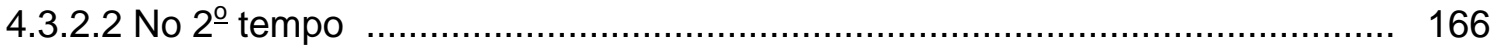

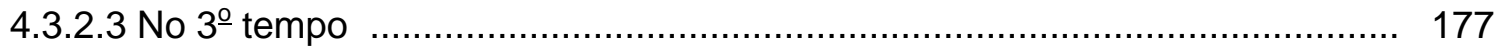

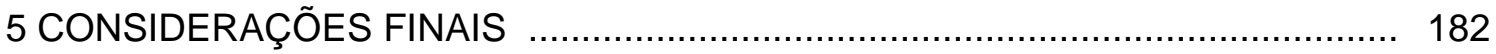

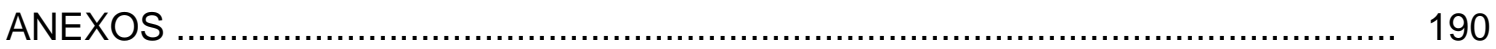




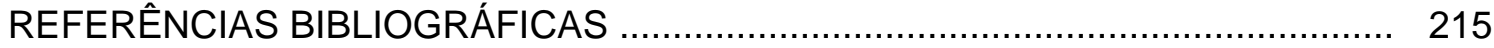

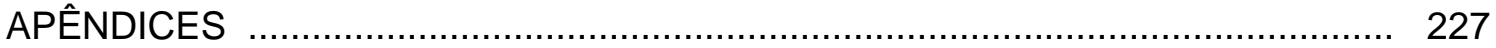




\section{LISTA DE FIGURAS}

Página

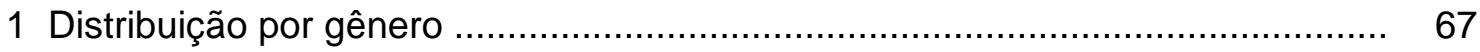

2 Distribuição por faixa etária ................................................................. 69

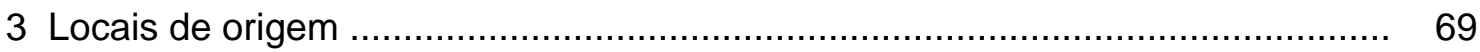

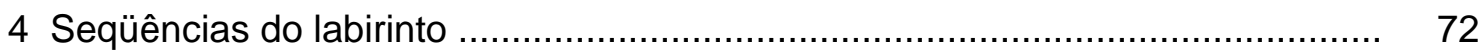

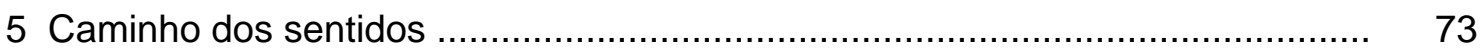

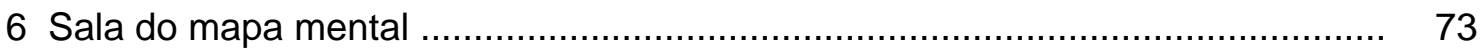

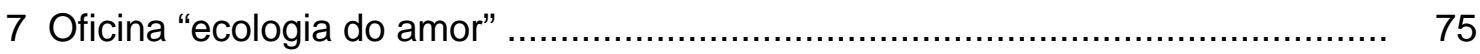

8 Oficina de educação a distância ........................................................ 76

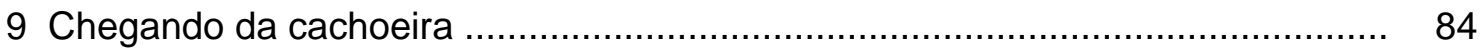

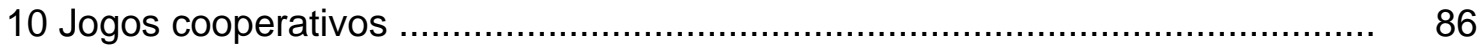

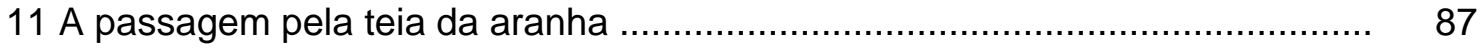

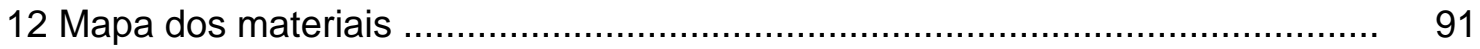

13 Seqüência acompanhamento in loco ...................................................... 96

14 Labirinto de Chartres ...................................................................... 142 


\title{
OLHARES DE EDUCADORES AMBIENTAIS PARA ESTUDOS DO MEIO E PERTENCIMENTO
}

\author{
Autora: SANDRA REGINA LESTINGE \\ Orientador: Prof. Dr. MARCOS SORRENTINO
}

\section{RESUMO}

Este estudo de caso desenvolveu-se junto a um curso de especialização em Educação Ambiental, que teve como eixos metodológicos a realização de um projeto de intervenção e a construção de comunidades de aprendizagem. Entre as disciplinas ministradas, uma foi analisada pela especificidade de utilizar os estudos do meio para valorizar a percepção e o contato dos estudantes com os ambientes fora de sala de aula e, a utilização do entorno - natural e construído - como recurso didático. Houve evidências de contribuições das atividades de ensino realizadas no curso e na disciplina, para as relações interpessoais e intrapessoais dos participantes e, também, para a discussão de conceitos presentes no ideário ambientalista, destacando-se entre eles o de pertencimento. Para obtenção dos dados primários, foram utilizadas diversas técnicas, iniciadas durante as atividades do curso, por meio de questionários com perguntas abertas, semi-abertas e depoimentos, até a coleta com os egressos, para a qual foram utilizadas entrevistas semi-estruturadas, acompanhamentos in loco, e de um laboratório conceitual. Os chamados dados secundários foram obtidos dos trabalhos produzidos pelos estudantes para finalização do curso: os projetos de intervenção educacional, as propostas de minicursos e os relatórios descritivoanalíticos. Esse rol de documentos, indicados para uma pesquisa qualitativa, forneceu 
um conjunto de dados que foram triangulados, visando responder se o estudo do meio pode ser um espaço de vivência que possibilita às pessoas compreenderem que a realidade é uma dimensão complexa e, que estimula o sentido de pertencimento, a ponto de agirem para a construção de sociedades mais justas, dentro de uma perspectiva emancipatória. Assim, foram apresentados, por meio de um "olhar vertical", os resultados sobre estudos do meio e pertencimento nas diferentes técnicas e, no "olhar transversal", elegeram-se dois sujeitos, mostrando-se sua caminhada dentro da pesquisa. O "olhar horizontal" trouxe nas considerações finais uma síntese do que foi discutido, permitindo afirmar que o conjunto de atividades desenvolvidas na disciplina contribuiu com o referido programa de formação, na medida em que houve associação entre elas e a contribuição para a consolidação dessa comunidade de aprendizagem. Houve confirmação entre os sujeitos da intenção de utilizar estudos do meio na sua prática profissional, que foi detectada e explicitada em vários momentos, evidenciandose no acompanhamento in loco. O sentido de pertencimento foi destacado de colocações, explícitas ou não, por meio do pensamento complexo. O referencial teórico utilizado para discussão caracterizou-se pelo compromisso de contribuir para a construção de sociedades mais justas e igualitárias e, também, para uma educação voltada à compreensão da realidade, numa perspectiva de emancipação social e política frente à problemática ambiental da contemporaneidade. 


\section{ATTENTION OF ENVIRONMENTAL EDUCATORS TO THE STUDIES OF THE ENVIRONMENT AND THE SENSE OF BELONGING}

Author: Sandra Regina Lestinge

Adviser: Prof. Dr. Marcos Sorrentino

\section{SUMMARY}

This study case developed together with a specialization course in Environmental Education that had the performance of an intervention project and the construction of training communities as methodological basis. Among the disciplines taught, one was analyzed according to the specificity in using field studies for valuing the students' perception and the contact with the environment out of the classroom, and the use of the framework - natural and built - as didactic resource. There were evidences on the contributions of teaching activities performed on the course and on the discipline, either for interpersonal and intrapersonal relations or also for the discussion of concepts present on the environmentalists' ideals, highlighting the belonging among them. In order to obtain the collection of the primary data, several techniques started along the activities of the course by means of questionnaires with open, semi-open questions, and personal accounts, including the collecting with the graduated students in which semi-structured interviews, follow-up in loco, and a conceptual laboratory were used. The so-called secondary data were obtained from the works produced by the students in order to finish the course: the educational 
intervention projects, the mini-courses proposals, and the analytical-descriptive reports. This group of documents, indicated to a qualitative research, supplied a set of data which were crossed aiming answering if the field study can be a live space which enables the people to understand that the reality is a complex dimension and that estimulates the belonging feeling up to acting for a construction of more fair societies inside an emancipatory perspective. Thus, through a "vertical perspective", the results of these field and belonging studies on different techniques were presented, and, through a "transversal perspective", two subjects, which showed their ways inside the research, were elected. The "horizontal perspective" brought, in the final considerations, a summary about what was discussed, allowing to affirm that the set of activities developed over the discipline contributed to the referred formation program as there was an association between them and the contribution for the consolidation of this training community. There was a confirmation among the subjects of the intention of using the field studies on their professional practices, which were detected and explicit in several moments, highlighting the follow-up in loco. The meaning of belonging was highlighted, explicitly or not, through a complex thought. The theoretical referential used for discussing was characterized by the commitment of contributing for the construction of more fair and equal societies, and also, for an education viewing the comprehension of reality, in a perspective of social and political emancipation facing the environmental problem nowadays. 


\section{INTRODUÇÃo}

"É que hoje nossa filosofia esterilizou o espanto do qual ela nasceu. É que nossa educação nos ensinou a separar, compartimentar, isolar, e não a ligar os conhecimentos, e portanto nos faz conceber nossa humanidade de forma insular, fora do cosmos que nos cerca e da matéria física com que somos constituídos" (Morin, 2000, p.48).

\subsection{Apresentação}

Quando ingressei na universidade, em 1979, tinha como ideal compreender os procedimentos e conhecimentos sobre produção animal, para, depois, atuar no campo, contribuindo com os pequenos e médios produtores rurais. A partir do terceiro ano do curso de Zootecnia na UNESP de Jaboticabal/SP, percebi que as disciplinas até então ministradas - mais voltadas para a pesquisa e produção em larga escala do que às necessidades e realidades cotidianas do meio rural brasileiro - eram insuficientes para responder às minhas expectativas iniciais. Passei, então, a pesquisar outras formas de produção, menos impactantes e que, basicamente, se contrapunham ao modelo visto nas salas de aula.

Dessa forma, junto com alguns colegas de república que também partilhavam dessa busca, iniciávamos estudos despretensiosos sobre diversos assuntos e nos exercitávamos, imaginando, a partir de um referencial geográfico, quais as possibilidades de se empreender uma propriedade agrícola alternativa, produzindo animais de pequeno e médio porte.

A cada novo encontro escolhíamos um local diferente e detalhávamos o que e como produzir. Abríamos um grande mapa do Brasil no chão da sala e as idéias surgiam: criar galinhas caipiras em sistema extensivo, cabras leiteiras para produção de queijo, peixes e processos de defumação, etc. Elocubrávamos também sobre 
detalhes da produção: ciclagem dos resíduos, embalagem e escoamento dos produtos, possibilidades de exportação, etc. Chegamos ao ponto de, no final do curso, pensarmos em comprar uma propriedade e pôr em prática nossas idéias e ideais. Foi também com essa "missão" que viajei para o Amazonas, em 1982, pelo projeto Rondon, buscando conhecer a região e encontrar um local para a empreitada.

Desci no aeroporto de Porto Velho, em Rondônia, e fui invadida por várias sensações, que me impregnaram. Poderia falar do calor, da umidade, da presença punjante da floresta. Hoje, porém, ao iniciar algumas leituras sobre percepção ( RIO, V.Del \& OLIVEIRA, L., 1999; Merleau-Ponty, 1999), compreendo que, o conjunto daqueles estímulos marcou-me tão profundamente, que foi capaz de mudar o rumo da minha vida. Era mais do que a simples realização de um sonho de uma universitária recém-formada.

Com um espírito de "investigadora", iniciei, então, uma série de viagens pela região amazônica. Percebia que a cada local a que chegava, vegetação, solo e clima apresentavam diferenças, às vezes mais sutis, outras bem marcadas. Diferentes também eram as relações que se estabeleciam a partir de determinado meio natural (a floresta) e os moradores/agricultores que eram produtores de gado nelore "derrubadores de mata", a seringueiros ou conservadores da floresta.

Fiquei encantada com aquele mosaico de possibilidades, texturas e cores que ia descobrindo. Aprendi, assim, vivendo, que a floresta é dinâmica, diversa, complexa. São muitas as florestas que formam a Amazônia. Percebi também a ingenuidade do nosso grupo, discutindo em cima de um mapa aberto na sala de uma cidade do interior de São Paulo, supor que poderíamos "enfrentar" aquela realidade do Norte do País, há mais de 22 anos.

Sem políticas públicas adequadas, o que se via eram ações predatórias e inadequadas, como por exemplo, as estradas construídas, mal conservadas e os inúmeros tratores abandonados pela rodovia transamazônica, camuflados pela vegetação, como que engolidos pelo "inferno verde"1 ou pela fumaça das queimadas, anunciando o deserto vermelho.

Dessas experiências, surgiu pelo menos um conflito - conviver com a diferença entre as realidades/necessidades da vida no campo e as teorias de sala de aula.

${ }^{1}$ Alusão ao livro "A selva amazônica: do inferno verde ao deserto vermelho" (Goodland, R.J.A.; Irwin, H.S.; 1975). 
Buscar elos que diminuíssem esse "abismo" passou a ser uma necessidade, com a qual convivi nos anos seguintes, nos projetos em que trabalhei no Amazonas e Pará. Ali aprendi muito. Aprendi a refletir, correlacionar e olhar com mais atenção e cuidado para o ser humano e a floresta.

Sabia que as concepções socioeconômicas que levaram à implantação do assentamento de colonos na Vila Apuy, no Amazonas, à construção da rodovia Transamazônica ou da barragem da usina hidrelétrica de Tucuruí, por exemplo, estavam equivocadas, fora de compasso, de tempo; incoerentes com aquela realidade, com aquele ritmo vivido e proporcionado pela floresta.

$\mathrm{Na}$ época, entre 1982 e 86, o termo ecologia começava a ser mais divulgado e conhecido, numa transição entre ciência e movimento social, mas pouco se discutia sobre as questões ambientais emergentes. Iniciativas e denúncias com um sentido conservacionista eram mais pontuais e pouca repercussão tinham nos veículos de comunicação. Cabe lembrar que, nessa época, algumas personalidades de reconhecimento mundial faziam campanhas isoladas em prol da preservação de algumas espécies animais ou ecossistemas. Enquanto isso, a floresta era devastada, queimada, ignorada.

Sem uma fonte de interlocução, eu fazia um diálogo surdo entre as minhas vivências até que li Capra (1982), em 1986. Foi então que percebi, fortemente, que minhas impressões e sensações poderiam ter eco. Havia nesse livro explicações sobre o modelo de vida econômico e social a que estamos sujeitos: modelo ultrapassado, passado do tempo.

Seguiram-se mais alguns anos de leituras e buscas, até que, em 1992, fui trabalhar em um colégio da rede privada confessional de São Paulo, onde participei de alguns projetos de estudos do meio, amplamente incentivados pela coordenadora pedagógica, durante os oito anos em que lá trabalhei: cidades históricas de Minas Gerais, Campos do Jordão, trilha do rio Itapanhaú, cidade de Santos, Serra de Paranapiacaba, estudos de Física e Biologia no Play Center em São Paulo, entre outros. Nessas oportunidades, procurei estimular nos alunos, durante a realização das atividades, os sentidos, o respeito à diversidade cultural, a interpretação da paisagem e do seu entorno, de maneira a despertar neles uma reflexão mais aprofundada sobre os conteúdos tratados em sala de aula e nos laboratórios, onde eu atuava mais diretamente. 
"As observações sensíveis permitem uma aproximação concreta com problemas ambientais e sensibilizam as pessoas não só para a sua compreensão como despertam a consciência e, em certos casos, até o compromisso para a busca de solução. O meio é um laboratório vivo: a escola, o córrego próximo, a população de um bairro, o distrito industrial, um parque, uma reserva florestal, uma chácara vizinha são elementos integrantes de um espaço, que podem ser pontos de partida para uma reflexão sobre o ambiente" (Pontuschka, 1998, p.9).

A idéia de utilizar o meio como recurso didático era latente em mim. Talvez, o primeiro estudo do meio que propus, mesmo sem saber o que era, foi em 1982 ao estagiar no zoológico de Belo Horizonte. Nessa oportunidade, convidei um grupo de colegas veterinários, que também estagiavam, para ao cair da tarde, irmos ao zôo e lá permanecermos até a noite. O sucesso dessa nossa visita foi absoluto. Lembro que meu maior prazer foi a empolgação deles ao se depararem com as diferenças de comportamento dos animais naquele horário.

As experiências vividas mostravam-se como uma "chave" importante, levandome a ousar mais. A cada estudo do meio em que estive envolvida no colégio ${ }^{2}$, obtinha respostas de que esse era um bom caminho para fortalecer relacionamentos mais amigáveis e compromissados entre os alunos e, também, entre eles e os professores. Além das contribuições advindas do estudo do meio para o relacionamento da turma, era notável a disposição geral para a aprendizagem. A percepção de que se tratava de um recurso em potencial era compartilhado entre alguns professores, mas nem todos. Seria muito trabalhoso, sendo apenas mais uma "tarefa" a cumprir pelos docentes?

Em 1995, quando iniciei o curso de especialização lato senso em Turismo Ambiental pelo SENAC/SP, encontrei uma comunidade (coordenadores, professores e colegas) que dialogava com seriedade sobre a problemática ambiental e a qualidade de vida. Certamente, o evento denominado "Rio 92" contribuiu para que a temática aparecesse cada vez com mais intensidade e insistência na mídia (jornais, revistas,

${ }^{2}$ Deve-se ressaltar que as atividades de estudo do meio nessa escola eram muito bem organizadas, com projetos pedagógicos interdisciplinares ou multidisciplinares. $\mathrm{Na}$ época, todas as séries faziam, via de regra, cinco saídas durante o ano. 
rádio, TV). A questão ambiental estava sendo revista e debatida com mais ênfase. Eu encontrava, enfim, os espaços de interlocução e reflexão que tanto procurara.

Ao final do primeiro semestre do curso, o SENAC abriu um concurso oferecendo bolsas de estudo para quem desenvolvesse um projeto de pesquisa. Elaborei então, sob o título "A agricultura orgânica abre as portas para o turismo ambiental", um projeto que me fez ganhar o primeiro lugar no concurso, além de favorecer o aprofundamento teórico nos dois temas propostos (agricultura alternativa e ecoturismo).

Passei a oferecer junto com outra educadora ambiental, a bióloga Rita Mendonça, vivências em uma horta de agricultura orgânica de Vargem Grande Paulista/SP, o sítio dos irmãos Nakashima. Com o trabalho da própria família buscavam recuperar o solo degradado pelo cultivo de batata. Utilizávamos, então, o nome fantasia "Caminhos do campo" (Anexo A).

Eu iniciava uma busca por referenciais teóricos que fundamentassem os conhecimentos empíricos adquiridos. Sabia que os estudos do meio contribuíam para a aprendizagem e os relacionamentos interpessoais, porém, nessa época, nunca havia lido nenhum filósofo, nem sabia da existência de "O caminho do campo" (Heidegger, 1969), texto no qual o autor se expressa, a partir de sua imersão na vida campesina.

Ao final desse percurso de experiências, viagens e reflexões, percebi que as minhas vivências fora da sala de aula tinham consistência e permitiam afirmar também que essas atividades foram importantes para melhorar a compreensão dos estudantes sobre o meio que os cercava, podendo contribuir também para uma melhoria na conscientização a respeito das questões ambientais na contemporaneidade.

Foi necessário desenraizar da família, dos amigos, da vida urbana, para enraizar no interior e, com os pés na terra, aprender a voar, a ser.

Refletindo sobre a importância e o potencial dos estudos do meio para aprofundar conhecimentos e se rever atitudes, conceitos, valores éticos e estéticos, percebo que há coerência em se pesquisar a utilização do entorno em processos de ensino-aprendizagem diversos (e mais especificamente naqueles voltados à Educação Ambiental) e também na promoção do sentimento de pertença. Sendo esse o assunto que me fez dar início ao trabalho que ora apresento. 


\subsection{0 problema}

O estudo do meio pode ser um espaço de vivência que possibilita as pessoas compreenderem que a realidade é uma dimensão complexa, e, que estimula o sentido de pertencimento, a ponto delas agirem para a construção de sociedades mais justas, dentro de uma perspectiva emancipatória? Como?

\subsection{A hipótese}

Os estudos do meio podem contribuir para a formação de educadores ambientais, capazes de utilizá-los como caminho para se atingir objetivos educacionais e do ambientalismo relacionados ao conceito de pertencimento.

\subsection{Os objetivos}

\subsubsection{Geral}

Contribuir para o fomento e o aprimoramento de programas educacionais que se fundamentem em conceitos chave do ambientalismo, como participação, emancipação, pertencimento e sobrevivência, e que utilizem estudos do meio para promover a melhoria das relações de ensino-aprendizagem, a percepção e compreensão do entorno na perspectiva da construção de sociedades sustentáveis.

\subsubsection{Específicos}

1. Descrever, avaliar e analisar a disciplina "Re-conhecendo o meio ambiente" e suas contribuições para o curso piloto de especialização "Formação de educadores ambientais para sociedades sustentáveis";

2. investigar, avaliar e analisar quais são as concepções que os egressos têm sobre pertencimento e estudo do meio, bem como as relações existentes entre esses conceitos;

3. analisar as propostas de estudos do meio presentes nos projetos de intervenção educacional e nos mini-cursos que os estudantes propuseram ao final do curso;

4. descrever e analisar alguns impactos epistemológicos e metodológicos de um curso de especialização. 


\subsection{A pesquisa}

A presente tese pretende analisar as decorrências e limitações do estudo do meio para a emergência e aprofundamento de conceitos estruturantes do ideário ambientalista. Fundamenta-se na exposição da proposta pedagógica e na interpretação dos impactos de um curso de especialização e de uma disciplina ministrada dentro dele, principalmente, sob a ótica dos egressos.

O curso piloto foi planejado e realizado na ESALQ/USP em Piracicaba/SP, e implementado entre setembro de 2000 e julho de 2001, sob a denominação de "Formação de educadores ambientais para sociedades sustentáveis" (APÊNDICE 1).

Os dez encontros presenciais e o cardápio de disciplinas oferecidas, bem como a comunicação eletrônica, foram concebidos e desenvolvidos para estimular relações que favorecessem o ensino-aprendizagem entre toda a comunidade envolvida: estudantes, docentes e a coordenação colegiada.

A diversidade na oferta de atividades didáticas foi um dos eixos articuladores do projeto pedagógico do curso, que visou contribuir para a constituição e consolidação de comunidades de aprendizagem; isto é, proporcionou-se espaços de interlocução para que os estudantes se organizassem, individual e coletivamente, em prol de ações que respondessem a algumas das questões ambientais emergentes.

Nesse sentido, um outro eixo articulador foi o projeto de intervenção educacional que os estudantes desenvolveram e implementaram ao longo do processo. Para isso, contaram com disciplinas específicas, o diálogo com a coordenação, tutores e pareceres dos colegas.

Deve-se destacar que foram promovidos diversos momentos para reflexão sobre a qualidade e responsabilidade no processo de ensino-aprendizagem nesse curso, pois considera-se que, tanto em Educação Ambiental quanto em outra área, deveriam ser continuamente propostas ações que formassem pessoas, visando melhorar as condições e a qualidade de ensino no Brasil.

Assim, faz-se mister analisar algumas atividades desenvolvidas em um programa de formação que teve a premissa de ser participativo, pois, ao envolver a comunidade, pode promover a sua emancipação, em busca de melhoria da qualidade de vida.

"Alguns programas procuram estimular os participantes a distinguir causas e conseqüências dos processos predatórios e 
degradadores da qualidade de vida, procurando identificar responsáveis e responsabilidades de cada um na preservação/conservação, recuperação e melhoria da qualidade de vida de todos. Porém, é bastante comum enfrentarem dificuldades para extrapolar o discurso crítico e provocar atitudes" (Sorrentino, 1995, p.8).

Essas e outras reflexões reafirmam a demanda para realização de cursos que desenvolvam uma didática participativa e que tenham uma opção política clara. Demo (2002), ao tratar de participação, comenta que é o processo histórico de conquista de autopromoção, sendo a melhor obra de arte do homem em sua história,

"Porque a história que vale a pena é a participativa, ou seja, com o teor menor possível de desigualdade, de exploração, de mercantilização, de opressão. No cerne dos desejos políticos do homem está a participação, que sedimenta suas metas eternas de autogestão, de democracia, de liberdade, de convivência" (Demo, 2002, p.12).

Nessa mesma perspectiva apontada por Demo e num escopo mais amplo, pode-se afirmar que, durante a Rio 92, ficou evidente a importância das contribuições vindas de várias partes do mundo para a produção de um documento em que a Educação Ambiental fosse tratada de maneira holística, e também como um exercício de participação, emancipação, autonomia e cidadania.

Nessa oportunidade, foram consultados diferentes setores das sociedades que, durante o "Fórum Internacional de Organizações não Governamentais e Movimentos Sociais" compilaram e redigiram um documento, que, até hoje, é utilizado como norteador da área: o "Tratado de educação ambiental (...)" (1992). Este documento será denominado neste trabalho apenas como "Tratado (1992)".

O referido evento contribuiu para desencadear iniciativas nas políticas públicas de meio ambiente e educação no Brasil, como se pode verificar na Política Nacional de Educação Ambiental - PNEA (1999), Lei $N^{0}$ 9.795, e a sua regulamentação pelo Decreto 4281 (2002), e no Programa Nacional de Educação Ambiental - ProNEA 
(2003), em que inclusive o Tratado $(1992)^{3}$ consta como anexo e é assumido como principal referência deste programa. Na Lei de Diretrizes e Bases - LDB (1996), de número 9.394, destacam-se os princípios de "liberdade de aprender, ensinar, pesquisar e divulgar a cultura, o pensamento, a arte e o saber"; de "pluralismo de idéias e de concepções pedagógicas"; e de "respeito à liberdade e apreço à tolerância".

Um outro documento importante, os "Parâmetros Curriculares Nacionais" PCN (1997), traz em seus objetivos, por exemplo, a necessidade de se conhecer o Brasil nas dimensões sociais e culturais para promover a noção de identidade nacional e o sentimento de pertença ao país, conceitos que são aprofundados neste trabalho, na revisão de literatura.

Além disso, consta como bloco temático de Ciências Naturais que:

"O tema transversal Meio Ambiente traz a discussão a respeito da relação entre os problemas ambientais e fatores econômicos, políticos, sociais e históricos. São problemas que acarretam discussões sobre responsabilidades humanas voltadas ao bemestar comum e ao desenvolvimento sustentado, na perspectiva da reversão da crise sócio-ambiental planetária" (PCN, 1997, p. 45).

Concebido para o ensino fundamental e médio, explicita o propósito do Ministério da Educação de contribuir para que o estudante enfrente o mundo como cidadão participativo, reflexivo e autônomo, conhecendo seus direitos e deveres.

Em contrapartida, em novembro de 2002, na cidade de Johannesburg, África, discutiram-se políticas para a sustentabilidade na reunião da Rio +10 , passados dez anos da Rio 92 e a impressão geral desse evento, divulgada na mídia, é de que houve pouco incremento nos compromissos ambientais, já que as perspectivas de melhorias sócio-ambientais do planeta permanecem inalteradas, pois não foram definidos prazos e metas para implementação do acordo sobre vários problemas, entre eles o energético, que deveria tratar, entre outras coisas, da produção de novas fontes de energia.

\footnotetext{
${ }^{3}$ Cabe destacar que, entre os seus princípios, consta que "a educação ambiental deve ter como base o pensamento crítico e inovador, em qualquer tempo ou lugar (...) promovendo a transformação e a construção da sociedade"; e o de "estimular a solidariedade, a igualdade e o respeito aos direitos humanos, valendo-se de estratégias democráticas e interação entre as culturas".
} 
Os problemas ambientais da atualidade possuem raízes no modelo de civilização branca européia ocidental, os valores da "modernidade" formam um "tripé" a partir das idéias de três grandes pensadores contemporâneos, conforme é compreendido por Santos (2001):

"Mas a extensão e a complexidade da construção político-jurídica da modernidade e, em especial, a tensão, a ela inerente, entre regulação e emancipação, são ainda mais evidentes quando Hobbes, Locke e Rousseau são considerados, no seu conjunto, como partes distintas de uma mesma e única constelação intelectual. Na verdade, cada um deles simboliza uma dimensão arquetípica de um projeto revolucionário global. O princípio do Estado (Hobbes), o princípio do mercado (Locke) e o princípio da comunidade (Rousseau) são constitutivos, em pé de igualdade, de um novo paradigma social que, para estar à altura das suas promessas, tem de assegurar o desenvolvimento equilibrado dos três princípios" (Santos, 2001, p. 137).

Reflexões como essa têm contribuído para a compreensão aprofundada da questão ambiental em toda a sua complexidade, repensando-a em suas múltiplas dimensões. Conforme a pergunta: "perante a individualidade da escolha humana, como é possível criar, a partir dela, uma vida colectiva?" (Santos 2001, p.130), como construir uma utopia de cooperação pelo bem comum? Pois, segundo Unger (2001):

"O que caracteriza uma postura utilitarista não é o fato de o ser humano utilizar os seres e as coisas. O que a caracteriza é a pretensão de reduzir os seres e as coisas à única dimensão da funcionalidade, como se sua existência não pudesse revelar outros múltiplos sentidos" (Unger 2001, p.112).

Assim, em consonância com esses pensamentos, surgiram perguntas, no decorrer da pesquisa, tais como: será que os estudos do meio contribuem para a compreensão de que a vida é formada por um sistema complexo e para a consolidação do sentimento de pertença nas pessoas? O recurso, natural ou construído, de um determinado entorno está lá, as pessoas estão lá. O que falta ou poderia ser feito 
nessas vivências, para que contribuíssem, de maneira efetiva, tanto para a aprendizagem de conteúdos escolares quanto para as reflexões do estudante sobre si mesmo, mudando a realidade do ensino - basicamente conteudista - no Brasil? Pois, via de regra:

"A escola, igualmente fragmentada em disciplinas, reproduz essa forma de entender o mundo e se transforma na instituição responsável pela divulgação e perpetuação dos conhecimentos acumulados pelas ciências ocidentais, cuja epistemologia nunca é questionada" (Mendonça, 2003, p. 27).

Os estudos do meio são oportunidades importantes para ampliar a percepção que se tem das coisas, pois não é óbvia ou pacífica a relação que o ser humano tem com o ambiente; seriam uma reação ao fato de que "diante da atitude objetivante, os seres e as coisas nada revelam; recolhem sua luminosidade e o seu mistério. No lugar de um cosmo translúcido que se oferece como epifania, o mundo se torna tão opaco quanto o olhar daquele que o vê" Unger (2001, p.112).

$\mathrm{Na}$ apresentação da pesquisa ilustrou-se de onde surgiram as inquietações que motivaram e mobilizaram a pesquisadora, influenciada há mais de 22 anos pelas perspectivas de utilização do entorno para aprendizagem formal ou não; manifestandose contrária à atitude objetivante perante os seres e as coisas.

Buscando-se responder às questões, objetivos e hipóteses desta pesquisa, fezse uma revisão de literatura, no capítulo 2, em três partes: estudos do meio, pertencimento e pesquisa qualitativa. Na primeira parte apresentam-se alguns autores que preconizavam sua utilização; destaca-se sua importância para a compreensão da realidade e também da sociedade contemporânea. Levantaram-se, ainda, algumas necessidades acerca de sua realização. As contribuições mais recentes de alguns autores e as considerações dão fechamento ao tema estudo do meio.

Pertencimento foi o conceito do ideário ambientalista utilizado para discutir e elucidar os dados obtidos. Considera-se a reflexão sobre pertencimento, a partir de um cenário social e político de modernidade que, sistematicamente distancia o ser humano da sua realidade, do seu lugar, como compreendido por Tuan (1983). Dessa maneira, o ser humano pode perder seu referencial de espaço e tempo, perder sua noção de escala e, conseqüentemente, sua potencialidade para agir. A frase "o ser que se 
coloca em estado de afinidade e de consonância com os demais seres pode ouvir a sua voz e conhecer os seus mistérios" (Unger, 2001, p. 71), traz à tona a premência de um pensamento complexo, numa intenção de se respeitar/considerar os seres que vivem ao redor.

"Precisamos compreender e assimilar em nossas atitudes que não é só poeticamente que habitamos o mundo, quer dizer, com enlevo, transfiguração e alegria, mas também habitamos o mundo prosaicamente, vale dizer, com sua opacidade, com seus limites e seu enraizamento inevitável. Dessa situação objetiva nenhuma droga nos liberta, só uma existência que saiba equilibrar transcendência e imanência como dimensões de toda a existência humana" (Boff, 2000, p.56).

A terceira parte da revisão de literatura trouxe alguns olhares sobre metodologia qualitativa, com uma breve descrição de quatro tipos de pesquisa possíveis de serem realizadas em Educação, conforme recomenda Lüdke e André (1986). São elas: a pesquisa participante, descrita por Brandão (1999a, 1999b) e por Demo (1984); a pesquisa-ação discutida por Thiollent (1985) e Barbier (1985); a pesquisa de abordagem etnográfica e o estudo de caso, que foram apresentados em alguns artigos de André $(1978,1984)$ e Stake (1982), entre outros. Este trabalho parece corresponder à perspectiva que Yin (2003) tem sobre um estudo de caso, na medida em que o autor afirma que é uma pesquisa empírica que investiga um fenômeno contemporâneo dentro de um contexto real, que nasce pelo desejo de se compreender um fenômeno social complexo.

O capítulo 3 detalha o curso de especialização, a disciplina e a metodologia do trabalho de campo. Relatando os caminhos trilhados no curso, fez-se uma breve memória desse piloto, contando-se o cenário onde foi planejada e implementada sua proposta pedagógica: como foi concebida, sua estrutura, o perfil do corpo discente, comentaram-se os encontros concentrados, a educação a distância e algumas oportunidades de aprendizagem.

Para descrever a disciplina, detalhou-se o planejamento que antecedeu sua realização e, depois, a viagem propriamente dita, com as atividades realizadas e organizadas pela pesquisadora. Essa disciplina diferenciou-se das outras, por ser um 
momento dentro do curso destinado à promoção de experiências na natureza, que se coadunavam com a proposta do curso de firmar compromissos com o coletivo, no sentido de contribuir para a construção de uma comunidade de aprendizagem, estimulando confiança, cooperação, responsabilidade, reflexão, etc, entre eles.

"Quando o campo é ampliado para a vivência e a experimentação, abre-se espaço para a manifestação de sentimentos, para estimular as percepções, para brincar com a afetividade. Essa experiência pode conduzir a reflexões profundas sobre diversos aspectos de nossa vida, comumente negligenciados pela proposta usual dos estudos do meio, baseada estritamente em conteúdos curriculares, praticada pelas agências especializadas e escolas" (Mendonça, 2003, p. 80).

Para isso, foram desenvolvidas no Horto da ESALQ, localizado em Itatinga, SP, atividades de campo, com dificuldades crescentes, apresentadas numa seqüência de desafios que foram enfrentados individualmente e com o grupo, com um feed-back bastante positivo, frente ao que foi proposto na ocasião. Buscou-se então analisar, discutir e compreender o que aconteceu com os participantes, através dos documentos recolhidos ao longo da pesquisa, tendo em vista que "nenhum comportamento de grupo, como, aliás, nenhum comportamento humano poderia se explicar unicamente em termos de causalidade histórica" (Mailhiot, 1991, p.50).

Conforme consta na introdução do Tratado (1992) e nessa mesma perspectiva, considera-se que a Educação Ambiental para a sustentabilidade, além de ser um processo de aprendizagem permanente, deve basear-se em valores e ações que contribuam para a transformação humana e social, estimulando "a formação de sociedades socialmente justas e ecologicamente equilibradas, que conservam entre si relação de interdependência e diversidade". Isso requer, então, valorizar processos em que a responsabilidade individual e coletiva, em âmbito local, nacional e planetário sejam elementos centrais.

Finalizando esse capítulo, há a descrição detalhada da coleta de dados, que iniciou no primeiro dia do curso de especialização, com o "ponto zero" no chamado "1o tempo"; em continuidade, no "2ํㅡ tempo", agruparam-se dados da disciplina e de 
entrevistas com os egressos; e, o "3ํㅡㄹ tempo" que se refere às últimas coletas, como por exemplo, a realização de um laboratório conceitual.

Assim, ao tratar-se de processos de formação de educadores, deve-se ressaltar que tanto a oferta quanto a demanda por cursos de especialização na área ambiental têm crescido nos últimos anos, especificamente em Educação Ambiental. Portanto, após o resgate da memória do curso, da disciplina em foco e, de explicitar a metodologia utilizada na pesquisa, no capítulo 4 expõem-se os resultados e discussão da pesquisa, através de três olhares, no sentido de contemplar os objetivos propostos, triangulando-se os sujeitos, de maneira a destacar-se a presença e pertinência dos estudos do meio apresentados, bem como do conceito de pertencimento em função dos ideários do ambientalismo e da Educação Ambiental.

As considerações finais conjuminam no capítulo 5 , com as reflexões e contribuições desse trabalho a partir dos resultados e da literatura.

Ressalta-se que, no decorrer da pesquisa, os sujeitos foram denominados de maneira diferenciada em função da sua condição de "estudantes" - durante o curso ou depois, "egressos" quando já especialistas. Algumas vezes, os "egressos" foram chamados "participantes" pelo caráter intrínseco que tiveram na pesquisa. 


\section{REVISÃO DE LITERATURA}

\subsection{Estudos do meio}

\subsubsection{Antes do século XXI}

"É alegre e instrutivo passear por entre uma vegetação que nos é estranha. Em meio às plantas habituais ou a objetos que conhecemos de longa data, não pensamos coisa alguma e, de que vale a contemplação sem a reflexão?" (Goethe, 1999, p.71).

É difícil precisar quando as excursões com caráter didático começaram a surgir. Talvez tenham se forjado como espaço de aprendizagem em viagens de naturalistas e exploradores ${ }^{4}$ atentos que, percebendo a riqueza e diversidade de sistemas naturais como fonte de conhecimento, tinham nos auxiliares dos trabalhos de campo, os seus aprendizes.

Na Europa, Goethe, que viveu entre 1749 e1832, contratou um jovem artista para retratar tudo o que lhe interessava, das paisagens às expressões humanas, como relata na sua obra "Viagem à Itália" (Goethe, 1999). Faz crer que aprimorou seus conhecimentos em diferentes áreas do conhecimento: Geologia, Botânica, Zoologia e Antropologia, no percurso que fez desde a Alemanha, entre 1786 e 1788, pois descreve lugares, solos, rochas, construções, costumes e culturas que encontrou pelo caminho. Pela sua narrativa, fica nítido o seu interesse científico pelas coisas, mas, principalmente, deixa transparecer a emoção e percepção aguçada que tinha dos lugares, das pessoas e cenários pelos quais passava.

\footnotetext{
${ }^{4}$ Entre alguns dos que vieram ao Brasil no século XIX, para ver e experienciar paisagens, estão: Alexander von Humboldt (1769-1859), Auguste de Saint-Hilaire (1779-1853) e Carl Philipp von Martius (1794-1868).
} 
Alguns textos da literatura brasileira, apesar de menos conhecidos, indicam uma "concepção ideológica" que ressalta a importância de atividades educativas utilizando o espaço natural. Considerando-os, portanto, bastante apropriados para esta discussão, alguns trechos serão destacados, comentados e apresentados a seguir, ipsis litteris.

Num artigo da revista editada pelo Instituto de Botânica de São Paulo, "Resenha Historica", o botânico alemão Hoehne (1937) expressa suas idéias, indicando a necessidade de propostas de programas instrutivos - com participação popular - que valorizem o interesse, o entusiasmo e o gosto pela flora brasileira nas "escolas primárias e superiores (...) onde o povo pode buscar conhecimentos e receber emulações para o estudo da botânica" (Hoehne, 1937, p.66). O cientista e pesquisador comenta sobre a necessidade de se cultivar o senso "esthético", promover o amor ao estudo da flora e da natureza e "instruir o homem no caminho da verdade" (Hoehne, 1937, p.66). Vai além, quando afirma que "já é tempo de se modificar a velha rotina do ensino da botânica" (Hoehne, 1937, p.66), que precisa ser apresentada como ciência recreativa, útil e atraente, pois só a teoria cansa e desanima o estudante.

Ao descrever a coleção do Museu Paulista, Hoehne faz sugestões ousadas para a época como de se produzir um "desenho animado" sobre orquídeas. Organizou programas de rádio com "conferências sobre a natureza brasílica", incentivou e promoveu a realização de cursos de aprendizagem para coleta e preparo de materiais para o herbário, entre outras ações.

Sua preocupação e crítica ao modelo de educação praticado na época destacam-se também neste trecho:

"O Brasil, que ainda póde se ufanar da sua bella natureza, deveria abrir esta nova picada de progresso da cultura e reforma no ensino de botanica. Se tem tão poucos cultores e estudiosos da scientia amabilis ${ }^{5}$, isto é devido, principalmente, não à carência de interesse do brasileiro pela natureza, mas ao defeituoso processo de ensino" (Hoehne, 1937, p.71).

${ }^{5}$ Esse termo significa "ciência amável", pois desperta o interesse e paixão aos que se dedicam à Botânica. 
Ele faz uma reflexão sobre a necessidade de mudança de hábitos e convenções sociais do povo, da necessidade de persistência e não violência para se alcançar as reformas de costumes, assim, dá ênfase ao "amor para tudo que é natural do paiz". Valoriza a emoção, ao se ter contato com a natureza, pois muitos "podiam passar por uma floresta sem sentir qualquer emulação para amar a terra". Cabe, ainda, destacar do texto um trecho que fala por si:

"'"Zurek zur Natur" (volta para a natureza) exclama o allemão e procura, no torrão transformado pela agricultura e industria, aquillo que a sua alma deseja. Contacto com aquillo que o Creador fez e em cujo meio o lançou é a felicidade do ser humano, porque a natureza é um lenitivo e estimulo ao mesmo tempo. Nas urbs, onde a vida se consome como o lubrificante e vapor de uma machina com os attrictos e o extinguir do fogo, o homem estiola-se como a flor sem orvalho e sem chuva. Os povos mais cultos compreendem a necessidade do contacto com a natureza" (Hoehne, 1937, p.74).

O cientista destaca a importância da Estação Biológica do Alto da Serra de Paranapiacaba, que pertencia então ao governo do Estado, tanto no que se refere a figuras ilustres que a visitavam, como as trilhas que davam condições para longas caminhadas na mata. "Têm acesso os verdadeiros amigos da natureza, os que se deleitam em estudar a oecologia e mutua dependencia dos seres, os que apreciam a natureza assim como ella é sem a intromissão do homem" (Hoehne, 1937, p.82).

O contato e a apreciação da natureza também motivou os trabalhos de outros grupos, como o dos escoteiros, por exemplo. No Brasil, desde o início do século XX, eles foram incentivados a realizar suas atividades num contato íntimo com o meio natural, caminhando alertas e cautelosos, observando pegadas, se orientando com facilidade através do sol, das estrelas ou com o auxílio de bússolas.

"A floresta é a escola da vida selvagem, escola que desenvolve no escoteiro a coragem, a tenacidade, o sangue frio, o espírito de observação, habituando-o a estar sempre alerta aos perigos que o 
podem rodear. É uma escola completa e encantadora" (Lobo, 1932, p.23).

A compreensão de que através de um contato com a natureza podem-se desenvolver habilidades e virtudes é destacada no trecho em que Lobo (1932) comenta:

"O mais interessante não é a observação de animaes prisioneiros

ou da natureza morta, mas a observação dos animaes e da propria natureza, em toda a sua plenitude de liberdade e vida. Ahi

é que as qualidades de coragem, paciencia, intelligencia e sagacidade do bom escoteiro se manifestam" (Lobo 1932, p.165).

O relato sobre estar ao ar livre continua com dicas para se seguir um animal, sem ser pressentido, como estudar seus hábitos alimentares, onde e como se abrigam, como criam os filhotes, entre muitas outras. A obra não se restringe só à vida no campo: o treinamento do escoteiro passa também pela vida nas cidades, observação de pessoas, ruas, casas.

É incrível a diversidade de jogos descritos no manual do escoteiro do "Velho Lobo" (1932), podendo, pelo seu conteúdo, ser considerado também como precursor do movimento ambientalista; com nomes como "jogos de observação e memória", "estudo da natureza", "ao ar livre" e "educação dos sentidos" as atividades explicitam uma intenção de contato direto, de apenas estar, compartilhar e aprender com a natureza.

Segundo Pontuschka (1994), os estudo do meio (será adotado EM na revisão) no Brasil começaram a ser utilizados nas escolas anarquistas que seguiam a pedagogia de Francisco Ferrer, e tinham a intenção de "fundar escolas livres, independentes do Estado, alfabetizando adultos e crianças num espaço de debate e diálogo, levando-os 'a pensar com suas próprias cabeças"' Pontuschka (1994 p.165). Para a autora, essa concepção contrapunha-se aos ideais dos empresários que, no início do século XX portanto, da industrialização no Brasil - não sentiam necessidade de alfabetizar o trabalhador. Os filhos das classes mais abastadas iam às escolas, enquanto que os filhos dos operários trabalhavam para ajudar os pais. Faziam parte dessas escolas não só os imigrantes italianos, mas também os espanhóis, portugueses e brasileiros. 
"O estudo do meio feito por tais escolas objetivava que os estudantes observando, descrevendo o meio do qual eram parte integrante poderiam refletir sobre as desigualdades, injustiças e promover mudanças na sociedade no sentido de saná-las. A escola livre estava muito vinculada ao conjunto dos movimentos sociais, políticos e culturais dos anarquistas, sempre no sentido de denúncia contra as arbitrariedades do Estado e da Igreja contra os trabalhadores adultos e crianças" (Pontuschka, 1994, p.168).

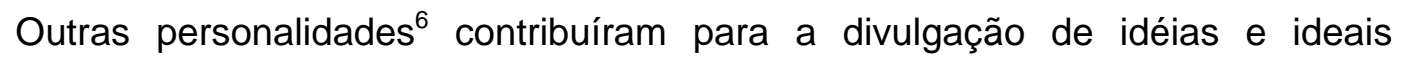
visando a uma educação popular fundamentada no respeito individual e coletivo, na promoção da autonomia, na liberdade de expressão:

"Os estudos do meio realizados pelas escolas tradicionais, com exceção, talvez, daquelas que adotam a metodologia Waldorf, infelizmente, têm uma preocupação longínqua com 0 desenvolvimento do espírito, abordagem tida como esotérica e, portanto, desprovida de validade científica. No entanto é de seres humanos que estamos falando quando elaboramos essas atividades e, nessa perspectiva, que perda para 0 desenvolvimento de nossos alunos significa essa visão materialista do mundo!" (Mendonça, 2003, p.48).

Mendonça (2003) afirma que os EM surgiram como atividade organizada em algumas escolas nas décadas de 50 e 60, ganhando força em várias instituições de ensino, a partir da década de 70.

Parece ser possível afirmar que os autores apresentados, ou pelo menos algumas das suas idéias, tenham também a sua contribuição no sentido de fomentar o movimento ambientalista, pois além de estimularem a aproximação à natureza de maneira cordial, amistosa, como a de um aprendiz - categoria a que todos os seres

${ }^{6}$ O brasileiro Paulo Freire (1921-1997), o francês Celestin Freinet (1896-1966), o ucraniano Anton Makarenko (1888-1939); e, o croata Rudolf Steiner (1861-1925) com a pedagogia Waldorf entre outros. 
humanos pertencem -, suas propostas embutem, no processo educativo, uma ação político-libertadora.

\subsubsection{Para compreensão da realidade}

"La vida urbana, e incluso la vida en el campo, cada vez más mecanizada, nos alejan del mundo físico y vivo; nos sumergem en el medio artificial de nuestras creaciones. Pronto seremos incapaces de imaginar las noches sin luz, el aire sin ruido y olor a petróleo, el espacios sin cubos de geometría cuyos únicos vacíos los llena una humanidad aglomerada. El tiempo sometido a la velocidad ya no tiene duración...toda interrupción de las leyes naturales en este mundo artificial, que el hombre cree falsamente dominar con sus técnicas, sorprende y escandaliza" (DebesseArviset, 1985, p.170).

Presencia-se, no início do século XXI, uma relação desbalanceada entre ser humano e natureza, pois essa é vista basicamente como fonte inesgotável de recursos para produção crescente de energia e de bens de consumo. Há, ainda, uma pressão mercadológica que impulsiona a consumir muito mais a cada instante, sem responsabilidade social, contribuindo dessa forma para que se consolide o distanciamento que tem nos livrado da responsabilidade perante as problemáticas socioambientais da contemporaneidade. Há um despreparo para o enfrentamento de problemas cotidianos, agravado pelo fato de que o conhecimento científico sobre a natureza e suas inter-relações é tão fragmentado quanto o currículo escolar brasileiro.

Para Brandão (1997) o conhecimento é uma gama de diferentes formas e dimensões do saber humano. "De qualquer maneira e sempre é preciso conhecer. Será preciso, o tempo todo, estar realizando a ousadia e o esforço de adquirir mais e melhor conhecimento" (Brandão, 1997, p.18). Nesse sentido, o EM será tratado aqui numa perspectiva de contribuir para o reconhecimento da realidade ${ }^{7}$, pois propicia reflexões e

\footnotetext{
${ }^{7}$ Considera-se aqui, realidade, numa perspectiva de compreender, transformar, intervir para a emancipação social.
} 
conhecimentos, desperta sensações e sentimentos que poderão potencializar e alavancar ações humanas em prol da melhoria na qualidade de vida.

Os EM são, via de regra, conhecidos como uma técnica em que se faz uso de determinado local para aprofundar conceitos e/ou conteúdos relacionados geralmente ao currículo escolar. Para que a sua realização atinja as expectativas dos participantes e, conseqüentemente, para que haja êxito na proposta, o acompanhamento das etapas de planejamento deve ser meticuloso, pois são muitas as variáveis que interferem: o interesse e envolvimento das pessoas, as condições (climáticas, de segurança) do local escolhido, a duração e planejamento das atividades, o preparo (teórico e prático) dos condutores, entre outras.

A realização desse tipo de atividade vem de muito tempo e é praticada em algumas escolas, ainda hoje, mesmo que aquém do desejado pelos estudantes que, em geral, se interessam por aulas em espaços diferenciados.

São diversas as contribuições que podem advir da realização dos EM. Podemos citar o estreitamento das relações intra e interpessoais que, apesar de ser importante, é pouco valorizado e difícil de ser mensurado e as múltiplas possibilidades de ensinoaprendizagem através da observação, percepção, interpretação e análise dos dados coletados, em busca de conhecimento e compreensão do meio em que se vive.

Nesse capítulo, pretende-se, também, provocar algumas reflexões sobre o modo como nos relacionamos com o entorno, da epiderme ao cosmo. Como estamos olhando, ouvindo, cheirando, sentindo, percebendo, falando, calando? Será que a realização de EM pode ampliar nossos horizontes, fazendo-nos sentir (mais) pertencentes à vida, ao mundo? Houve momentos de ruptura que nos distanciaram dos rios, da terra, do prazer dos ventos, do medo dos furacões e avalanches, do aprendizado na e da natureza?

Busca-se conhecimento científico sobre o planeta Terra e o espaço, investindose quantidades expressivas de "tempo e dinheiro" na tentativa de se encontrar respostas também a outras questões primordiais, como por exemplo: qual a origem da vida no planeta? De onde viemos? Há um "elo perdido"? Há formas de vida em outros planetas? "Actualmente, la curiosidade despertada por los espacios ignorados abandona la tierra por los astros. Los héroes ya no son Cristóbal Cólon, Amundsen o 
Scott, sino los astronautas. Se ha trastornado un mundo" (Debesse-Arviset, 1985, p.155).

Sabe-se, por exemplo, que combinações de certos gases e partículas em suspensão na atmosfera são co-responsáveis pela manutenção das condições da vida humana, vegetal e animal no planeta. Os processos físicos, químicos, geológicos e biológicos que nos envolvem são bastante dinâmicos, porém, o que se quer destacar é que, praticamente, não se tem consciência e conhecimento das suas correlações, bem como das repercussões das ações antrópicas sobre os diferentes níveis de interação do ser humano com a natureza. Nessa situação, podem ser considerados ainda dois agravantes: o distanciamento cognitivo e sensorial do entorno, do cotidiano, do saber empírico e, as evidências das restrições de acesso ao conhecimento científico e as novas tecnologias para todos. Isso nos distancia da nossa própria vida, do mundo que nos cerca, das possibilidades de inferir e interferir nele.

Quanto conhecemos do ambiente natural? Quantos de nós (e quantas vezes) paramos para pensar que as condições aprazíveis (mesmo que aparentemente inóspitas de algumas regiões extremas) que há neste planeta são as bases para a magnífica diversidade de espécies vegetais e animais, muitas ainda desconhecidas? Apesar de, geralmente, dar-se ênfase à biodiversidade, sabe-se que há associações importantes também entre as grandes massas de água, os ventos e o clima. Deve-se ressaltar que todos esses sistemas estão interligados e são interdependentes.

Mas houve um tempo em que o conhecimento, mesmo que empírico, pertencia ao homem do campo. Sabia-se, por exemplo, as mudanças das estações ou o rigor de um inverno pelas formas e cores das nuvens, pela direção dos ventos ou migração de animais. Não se quer dizer com isso que esse "tempo pretérito" tenha se perdido totalmente, mas muitos conhecimentos tradicionais se perderam com o extermínio das nações indígenas do Brasil e de outros povos e culturas da América Latina. Apesar disso, extrapolando-se para a realidade escolar:

"O contato direto e reflexivo sobre o espaço de um local seja da realidade do aluno ou outras, permite que o estudante forme referenciais para entender que o meio é historicamente dinâmico; ele foi e será transformado: as próprias diferenças entre o tempo das construções documentam as mudanças". (Pontuschka, 1998). 
Numa reflexão abrangente, Santos (2002) faz uma crítica que pode convergir para essa problemática, quando afirma que "a ciência moderna desconfia sistematicamente das evidências da nossa experiência imediata" (Santos 2002, p.12), isto é, o conhecimento científico faz um desvendamento da natureza que não é contemplativo, e sim ativo, pois visa conhecer a natureza para subordiná-la às necessidades e vontades humanas.

O que se foi, ou parece que se perdeu em grande parte, é a capacidade de se perceber e desvendar os sinais. Perdeu-se o "tempo" necessário para a observação, leitura, reconhecimento e compreensão do entorno. Perdeu-se também o "tempo" da fruição, do devaneio, do deleite ou do contemplativo, pois visa-se "conhecer a natureza para a dominar e controlar" (Santos, 2002, p.13). É como se uma estrutura gigante, invisível, impusesse um novo continuum, uma nova velocidade e ritmo, gerando uma outra qualidade da relação, distanciando as impressões internas e externas da consciência reflexiva sobre elas, do corpóreo humano. "A cada dia se passam muitas coisas, porém, ao mesmo tempo, quase nada nos acontece" (Bondía 2001, p.2).

Os seres humanos já estiveram mais ligados à realidade (pelo menos local) pela própria necessidade de sobrevivência. Desde os primórdios, os habitantes das cavernas, como coletores e depois caçadores, tinham os sentidos aguçados; porém atualmente, parece haver um "sedentarismo intelectual" causado pelo modo de vida contemporâneo, anestesiando-nos no conforto proporcionado pela utilização de computadores, televisores, supermercados. Há poucas surpresas nos grandes centros urbanos, além do estresse causado pela violência, poluição, etc. Os sentidos embotamse, distanciando-nos da possibilidade de nos apropriarmos de algo que também nos pertence e da qual fazemos parte - a Terra ${ }^{8}$.

Os EM realizados em áreas naturais, numa perspectiva de compreender a complexidade humana (Morin, 2000), que explore e respeite as sensações e percepções (frio, calor, desconforto, cansaço, prazer etc) podem levar a modificações e autoconhecimento, revelando o sentimento de pertença; pois "ao ampliar a noção de si mesmo, o mundo também se amplia" (Mendonça, 2003, p.81).

\footnotetext{
${ }^{8}$ Referimo-nos aqui a duas idéias: da hipótese de Gaia, mais difundida por James Lovelock e Lynn Margulis como "um complexo entrelaçamento de sistemas vivos e não-vivos dentro de uma única teia" (Capra, 1996, p. 173-4); e também a de Serres (1994), na qual o homem deve buscar um estado de "paz e o amor", e para tal deve renunciar ao contrato social primitivo, firmando um novo pacto com o mundo: o contrato natural.
} 


\subsubsection{Contribuindo para a desalienação}

"Não estou fazendo esta maravilhosa viagem com o propósito de me iludir, mas sim de me conhecer melhor a partir dos objetos que vejo" (Goethe, 1999, p.53-54).

Pode-se afirmar que o distanciamento da "realidade vivida", imposto também pela velocidade do modo de vida contemporâneo diminui a compreensão e a "apropriação" do cotidiano nas diferentes instâncias sociais, principalmente nas escolas, onde deveria se dar o inverso, através de ações, discussões e reflexões.

Práticas que visem à resolução de problemas (Ott, 1989) e à compreensão da realidade (Nidelcoff, 1979), por exemplo, deveriam ser mais estimuladas no ensino formal e não formal. A atividade escolar, em geral, parece desconsiderar a perda paulatina da compreensão, do contato lúdico que se tem em relação ao ambiente mais próximo, o entorno ${ }^{9}$. Apesar disso, Carvalho (2002) afirma que:

“Outras correntes pedagógicas antes das 'Educações Ambientais' também se preocuparam em contextualizar os sujeitos no seu entorno histórico, social e natural. Trabalhos de campo, estudos do meio, temas geradores, aulas ao ar livre, não são atividades inéditas na Educação. Estes recursos educativos, tomados cada um por si, não são estranhos às metodologias consagradas na Educação como aquelas inspiradas em Paulo Freire e Piaget, entre outras" (Carvalho 2002, p.84).

Nesse sentido, Carvalho (2002) comenta que caberia à Educação Ambiental a revisita desse "conjunto de atividades pedagógicas, atualizando-as dentro de um novo horizonte epistemológico onde o ambiental é pensado como sistema complexo das relações e interações da base natural e social (...)" (Carvalho, 2002, p.84).

A escola, enquanto espaço de formação crítica, deveria promover constantemente práticas educativas voltadas à conscientização da problemática

\footnotetext{
${ }^{9}$ Segundo dicionário Aurélio (Aurélio Buarque de Holanda Ferreira, Novo Dicionário da Língua Portuguesa, 1986, $2^{\circ}$ ed.), ambas as expressões "em torno" e "entorno" caracterizam: região que se situa ao redor de um determinado ponto, circunvizinhança, conjunto de paisagens.
} 
socioambiental e conseqüente busca de soluções. Bondía (2001) comenta que o sujeito moderno,

“(..) além de ser um sujeito informado que opina, além de estar permanentemente agitado e em movimento, é um ser que trabalha, tanto o mundo "natural" quanto o mundo "social" e "humano", tanto a "natureza externa" quanto a "natureza interna", segundo o seu saber, seu poder e sua vontade" (Bondía 2001, p.5).

O autor faz uma crítica, comentando que "na escola o currículo se organiza em pacotes cada vez mais numerosos e cada vez mais curtos. Com isso, também em educação estamos sempre acelerados e nada nos acontece" (Bondía, 2001, p. 4). Essa crítica remete a uma problemática sobre o volume de informações e áreas de conhecimento a que se está exposto (nos bancos escolares e além deles) e que se tem à disposição permite uma experiência ${ }^{10}$ verdadeira dentro de um processo educativo.

"Cada vez estamos mais tempo na escola (...) mas cada vez temos menos tempo. Esse sujeito da formação permanente e acelerada, da constante atualização, da reciclagem sem fim, é um sujeito que usa o tempo como um valor ou uma mercadoria, um sujeito que não pode perder tempo" (Bondía, 2001, p.4).

Então, na busca de respostas às perguntas iniciais, mais abrangentes (e que remetem ao passado ou ao futuro), há também outros questionamentos primordiais, não menos importantes, como por exemplo: quem sou? Onde estou? Para onde quero prosseguir? Certamente, o corre-corre da "vida moderna" dos grandes centros urbanos tem contribuído para que não se pense nisso, para que não se busquem respostas ou, até, que não se façam tais perguntas.

Em uma comunicação oral proferida em novembro de 2003, na Universidade São Francisco, em Bragança Paulista/SP, Sorrentino afirmou que a alienação pode ser mantida e estimulada por um modo de vida consumista, "fast food", perdendo-se o olhar

${ }^{10}$ Experiência é, segundo o mesmo autor, "o que nos passa", "o que nos acontece", "o que nos toca". E não o que se passa, o que acontece ou o que toca. "Nunca se passaram tantas coisas, mas a experiência é cada vez mais rara" (Bondía, 2001, p.2). 
atencioso e reflexivo para si próprio e para o outro. Em contrapartida, poderia-se promover um modo de vida baseado no "slow food"11, um movimento internacional que nasceu na Itália e que promove uma educação do paladar, resgatando-se sabores e saberes, em contraposição ao modo de vida alienante que predomina em várias sociedades do mundo.

"Ragionare sul piacere che questo mondo ci può dare non può prescindere dal ragionare sulla necessità di mantenere un equilibrio di rispetto e di scambio con la natura, con l'ambiente. Ecco perché ci piace definirci "ecogastronomi". Siamo sicuri che il nostro piacere non può non essere legato al piacere degli altri, ma allo stesso modo è legato all'equilibrio che sapremo mantenere (e in molti casi ritrovare) con l'ambiente che ci ospita"12.

Nessa perspectiva que valoriza a alimentação "consciente", não só como uma necessidade básica de todo ser humano, mas também como um hábito cultural ou um modo de vida, cabe lembrar que o acesso à qualidade e à quantidade de alimentos saudáveis é bastante desigual entre os hemisférios norte e sul, refletindo diretamente nas condições de vida das populações.

Retomando a reflexão sobre processos desalienantes, para usufruir a vida em sociedade, deveria-se promover a aproximação do sujeito com as coisas e acontecimentos, não aleatoriamente, mas conjugadas com atenção, paciência e tolerância. Para isso, pressupõe-se a valorização de uma característica da pessoa humana: a de ser "um ente associativo, porque o ser humano não existe sozinho" (Dallari, 2001, p.86). Este autor afirma que é uma característica humana viver em associações na busca por modos de convivência e é na busca por regras de convivência que contribuam para uma harmonia social, e na fixação destas regras, que

${ }^{11}$ Conforme consta no site italiano http://slowfood.it/ita/sf_cose/sf_cose.lasso (10 maio 2004) sobre gastronomia, "slow food" se contrapõe à tendência de "estañarização/padronização" do gosto, defendendo a necessidade de informação por parte do consumidor do mundo.

${ }^{12}$ A tradução deste trecho é de Kátia Cristina Bortoletto: "Pensar sobre o prazer que este mundo pode nos dar não pode estar desvinculado do pensar sobre a necessidade de manter um equilíbrio de respeito e de troca com a natureza, com o ambiente. Eis porque gostamos de definirmos "ecogastrônomos". Temos certeza de que o nosso prazer não pode não estar unido ao prazer dos outros, mas, ao mesmo tempo, está unido/ligado ao equilíbrio que saberemos manter (e em muito casos reencontrar) com o meio que nos acolhe". 
a participação passa a ser não só um direito, mas um dever que não se pode deixar de cumprir.

É nesse cenário que dá ênfase à necessidade de uma participação dialógica e potencializadora de ações críticas e reflexivas, que se pretende incentivar propostas de realização de $\mathrm{EM}^{13}$, pois no cotidiano escolar há oportunidade, num ambiente profícuo, de se fomentar atividades que contribuam para a aprendizagem de crianças, adolescentes e adultos, pois:

"A escola tem que ajudar a criança para que, em seu processo de crescimento, ela vá compreendendo a realidade que a cerca e nela vá se localizando lúcida e criativamente. Este processo a inicia na realidade imediata com o meio: aprende a VER no mesmo, para em seguida estender seu olhar na direção de horizontes mais largos" (Nidelcoff, 1979, p.11).

Método, técnica, atividade de campo, aula prática, excursão, vivência ou outra nomenclatura que o identifique, destaca-se a importância de se criar "elos" ou "pontes" que instiguem a proposição e realização de EM numa perspectiva de contribuir para a construção de sociedades mais justas e igualitárias, ressaltando-se o "contexto político da relação educativa" (Demo, 2002, p.91).

A utilização do $E M^{14}$ pode contribuir para uma formação mais "integral" do indivíduo, quando se propõe um olhar cuidadoso e atento para o que está à volta, para a compreensão da realidade, do que acontece no entorno. A partir desse reconhecimento, acredita-se poder inferir que sujeitos sociais distintos se potencializem para ações que sejam mais responsáveis no tocante à questão ambiental. Pontuschka (1994) destaca a importância de se definir o que se entende por EM - uma "prática social" - a partir de trabalhos realizados "no passado até nossos dias".

\footnotetext{
${ }^{13}$ Nidelcoff (1979), ao explicar o que é EM, coloca que meio é a realidade física, biológica, humana que nos rodeia e que se liga de maneira direta através da experiência; e quanto ao estudo, comenta que este pode apresentar valores e gradações diferentes: aproximar-se afetivamente, descobrir coisas, exprimi-las, explicá-las, analisá-las.

14 Segundo Pontuschka (1994), um estudo do meio pode variar "desde uma saída de estudantes e professores" com o objetivo de entretenimento, até "trabalhos interdisciplinares que demandam pesquisas de campo, bibliográfica, iconográfica", levando a um investimento e necessidade de trabalho tanto individual quanto coletivo.
} 
Para que um EM seja caracterizado como atividade de Educação Ambiental, precisa estar em consonância com um pensamento mais complexo sobre "meio ambiente". Parece haver um consenso entre alguns autores de que a Educação Ambiental tenha um caráter não apenas político, mas uma intenção maior de politizar e capacitar cidadãos e cidadãs a tomarem posicionamentos, por exemplo, sobre os altos padrões de consumo de países industrializados do hemisfério norte e a sustentabilidade do planeta. Assim, Freire (2000), Sato (2001), Mendonça (2003), entre outros autores, apontam para a necessidade de que haja um comprometimento verdadeiro frente a essas discussões.

É nesse sentido que algumas atividades práticas de Educação Ambiental passam por críticas como as que Michele Sato aponta:

"Proliferam-se, assim, ações pontuais de abraçar árvores ou oficinas de reciclagem de papel, sem nenhuma postura crítica dos modelos de consumo vivenciados pelas sociedades, ou pela análise do modo de relação dominadora do ser humano sobre a natureza, com alto valor antropocêntrico" (Sato 2001, p.R-16).

Com um questionamento pertinente sobre outras práticas educacionais, Carvalho (2000) questiona a transmissão de informações por educadores que utilizam as trilhas de interpretação, em geral, com grande peso para os conhecimentos vindos da Biologia, como o funcionamento dos ecossistemas e as interações entre os elementos da natureza. Ressalta que a "tradição explicativa das ciências naturais" contrapõe-se a uma "ação interpretativa e via compreensiva de acesso ao meio ambiente" que indicariam um caminho para uma Educação Ambiental de perspectiva filosófica hermenêutica. "Educar, compreender, tornam-se desde uma perspectiva hermenêutica, uma aventura onde o sujeito e os sentidos do mundo vivido estão se constituindo mutuamente da dialética da compreensão/interpretação" (Carvalho, 2000, p.8).

Sendo assim, acredita-se no potencial do uso dos EM para a relação de ensinoaprendizagem visando criar e fortalecer vínculos - objetivos e subjetivos - que contribuam tanto para a compreensão da realidade, como para a consolidação do 
sentimento de pertença nos indivíduos, numa perspectiva de emancipação sociopolítica em prol de um projeto de felicidade.

\subsubsection{A sua realização}

Os EM, até hoje, foram mais utilizados no ensino da Geografia; mas outras disciplinas, como por exemplo Biologia, História, Ciências, Matemática, Literatura, utilizam-os como estratégia de ensino-aprendizagem (Nidelcoff, 1979; Debesse-Arviset, 1985; Pontuschka, 1994; Pegoraro, 2000).

Espacialmente, os EM podem acontecer desde o entorno mais próximo dos estudantes, pesquisando a partir do próprio corpo e, num caracol imaginário, ir se expandindo para a sala de aula, o prédio (ou local dos estudos), o jardim ou o espaço em volta, o quarteirão que abriga a escola e os adjacentes, o bairro e comunidades nele envolvidas e assim por diante, até onde o fôlego e entusiasmo ou a necessidade indiquem como adequados e oportunos. "Qualquer pessoa pode fazer uma expedição no quintal da própria casa ou no jardim mais próximo. O que distingue, porém, uma expedição de um simples passeio é o fato de termos, no primeiro caso, um objetivo: o de conhecer" (Branco, 1984, p.5).

Um EM pode ser caracterizado como um método na medida em que permite ao estudante observar, descobrir, documentar, utilizar diferentes meios de expressão, desenvolvendo assim, um espírito de síntese; ou como técnica, pelo seu valor informativo em diferentes áreas do conhecimento, de forma não "livresca", através da experiência vivida (Pontuschka 1994). No entanto é importante utilizar-se estratégias e vivências específicas que favoreçam as relações interpessoais e intrapessoais.

Nidelcoff (1979) considera que o EM pode ser "integral“ ou "parcial". No primeiro caso, exemplifica com "o estudo de uma população, de um bairro, de uma cidade, sob todos os seus aspectos" e ressalta que esse é um trabalho mais difícil, que requer "ação coordenada de várias equipes, durante bastante tempo" (Nidelcoff 1979, p.12-13); na outra possibilidade, de um estudo parcial, sugere um "recorte" ou apenas um aspecto de um tema, por exemplo, o estudo da localização e instalações de uma fábrica, os hábitos alimentares de uma população entre outros.

Para complementar a idéia de EM, acima citada, cabe mencionar que: 
"El estúdio de los médios geográficos, a través del análisis de las situaciones complejas ${ }^{15}$ a partir de todos los factores implicados: tiempo, espacio, fuerzas económicas y financieras, es una orientación intelectual, un verdadero estruturalismo. Obligando a pensar "juntas", causas múltiples y no siempre suficientes, ejerce una dialética que ya no puede confundirse con la demonstración matemática ni con la comprensión literaria" (Debesse-Arviset 1985, p.169-170).

Para Bondía (2001) é dar sentido à experiência, "sobretudo dar sentido ao que somos e ao que nos acontece" e discute os termos "informação", "conhecimento" e "aprendizagem", pois conhecimento e sabedoria passam pela quantidade de informação ou uma opinião que se tem sobre algo. A importância da experiência, na citação de Bondía, remete e reforça, além do modo de ser e viver experienciado, à necessidade do "momento de parada":

"A experiência, a possibilidade de que algo nos aconteça ou nos toque, requer um gesto de interrupção, um gesto que é quase impossível nos tempos que correm: requer parar para pensar, parar para olhar, parar para escutar, pensar mais devagar, olhar mais devagar, e escutar mais devagar; parar para sentir, sentir mais devagar, demorar-se nos detalhes, suspender a opinião, suspender o juízo, suspender a vontade, suspender 0 automatismo da ação, cultivar a atenção e a delicadeza, abrir os olhos e os ouvidos, falar sobre o que nos acontece, aprender a lentidão, escutar aos outros, cultivar a arte do encontro, calar muito, ter paciência e dar-se tempo e espaço (Bondía, 2001, p.5).

${ }^{15}$ É oportuno aproximar da complexidade proposta por Edgar Morin (1995, 2000). "O termo latino complexus significa 'o que é tecido junto'. É o cerne da epistemologia da complexidade" proposta por esse autor (Petraglia, 2000, p.9). Refere-se a uma contraposição ao pensamento reducionista e linear, e dá destaque à união, à dependência, à multidimensionalidade dos saberes, da vida. 
Para Tuan (1983), a experiência pode ter a conotação de passividade, pelo que uma pessoa suportou, tem sofrido ou aprendido com os acontecimentos. Mas experienciar é também aprender a partir da própria vivência, atuar e criar a partir de dados, apesar de não se poder conhecer sua essência, "o que pode ser conhecido é uma realidade que é um constructo da experiência, uma criação de sentimento e pensamento" (Tuan 1983, p.10). Então, pode-se depreender que, para experienciar, atuar e criar a partir de dados, como nos indica esse autor, é necessário o "gesto de interrupção", a que se refere Bondía (2001), para completar os processos cognitivos.

"Partir de la observación del entorno es un ejercicio de atención, de la aptitud para distinguir lo esencial de lo contingente; una incitación a imaginar comparaciones verificadores, esbozo de generalidad. Cada uno descubre los efectos de su propia acción en este medio físico, biológico, humano, y su poder a veces destructivo, así como la posibilidad de una belleza nueva" (Debesse-Arviset, 1985, p.161).

Nos EM, o exercício de observação e atenção deve ser adequado à faixa etária do grupo, bem como as atividades e temas coerentes com a proposta pedagógica da instituição. É importante o comprometimento, a responsabilidade e o envolvimento do coletivo no estudo. Sem, giz, quadro negro ou carteiras, o EM torna-se um momento especial, pela oportunidade de se inovar metodologias de ensino - aprendendo-se em outros ambientes, mas não só. Os estudantes, via de regra, sentem-se mais "soltos", ficam mais entusiasmados, participam com comentários e observações, despertando a atenção também do educador "aprendente". A paisagem - urbana ou rural - é mais que apenas um cenário. Os estudantes, educadores, cidadãos ou moradores são pessoas que se expõem ao compartilhar, socializar, indagar, pesquisar.

"O conhecimento se adquire através da observação prolongada de cada objeto: animal, vegetal ou mineral; da comparação com os demais objetos; do acompanhamento demorado e paciente do seu modo de ser, de viver, de relacionar-se com o meio, com os outros seres, com os elementos e fenômenos da natureza. É, realmente, enxergar o mundo que nos cerca" (Branco, 1984, p.6). 
É esperado e interessante de se observar a mudança de comportamento em relação àqueles que os estudantes normalmente têm em sala de aula. É possível que isso se deva a outras habilidades que são estimuladas nesses eventos. Assim, um estudante mais "inquieto e falante" pode ser um bom interlocutor, vindo a motivar e agregar a turma; uma estudante mais tímida pode revelar-se uma boa observadora de pássaros, contribuindo para um contato afetivo e efetivo com outras fronteiras do conhecimento.

Pensando-se em contribuir para a construção de sociedades com pessoas mais conscientes sobre a importância de se conhecer, respeitar e conservar a natureza, os EM, de forma geral, visam à aplicação de alguns recursos didáticos fora da sala de aula, utilizando a natureza ou o ambiente "extraclasse" como espaço pedagógico, mais do que um "laboratório vivo", de forma a contribuir, em última instância, para a discussão da problemática ambiental.

"As atividades de campo são os laboratórios onde se concretizam, emergem e interagem os conteúdos teóricos, elaborados em sala de aula, com a realidade concreta das transformações da natureza. É o local onde se confrontam os valores exibidos dentro de "quatro paredes" com os praticados nas atividades de campo" (Tamaio, 2002, p.93-4).

O propósito de um EM deve ser (e estar) bem claro, definido e detalhado, tanto para os proponentes (professores, direção, coordenadores, guias), quanto para os estudantes. Nesse sentido, algumas perguntas podem ajudar: qual (quais) o(s) objetivo(s) do estudo? A quem se destina? Qual a duração? Quais as maiores dificuldades ou limites?

Para os proponentes, há, no mínimo, dois caminhos que devem ser percorridos concomitantemente: o "pedagógico" e o "logístico".

A "logística" compreende tudo o que diz respeito ao planejamento e à realização da saída em si: transporte, trajeto, agendamento de horários, alimentação, primeiros socorros, entre outros. É importante fornecer algumas orientações sobre roupas e alimentos mais adequados, cuidados com objetos de uso pessoal (máquina fotográfica, medicamentos, etc), detalhar e verificar cada item e, por segurança, deve-se manter o que foi acordado, isto é, evitar mudar - aleatoriamente - um roteiro pré-estabelecido no 
"meio do caminho". As decisões tomadas no coletivo geralmente têm mais credibilidade e geram confiança para o desempenho dos trabalhos no campo.

A necessidade de realizar um EM pode surgir dos próprios estudantes, ou então ser prevista dentro do planejamento pedagógico da escola. Dependendo da complexidade da saída, o ideal é que a apresentação dos conteúdos curriculares comece com alguma antecedência, na sala de aula, para o envolvimento e motivação, visando estimular a noção de responsabilidade entre os estudantes.

O ideal é que, a partir de um projeto, se construa um roteiro que auxilie a sistematização das anotações e observações, dos comentários pessoais, dados históricos, geográficos, socioeconômicos, desenhos/croquis, pequenas entrevistas, horários previstos, etc. Esse guia, caderno ou diário de campo serve como orientação, "base de dados" tanto para o educador quanto para os estudantes utilizarem antes, durante e após o "evento", pois envolve pesquisa, organização, levantamento de questões a serem investigadas, e posterior seleção de informações, para facilitar a comparação entre os dados levantados e os conhecimentos já organizados por outros pesquisadores, até as interpretações pessoais e conclusões.

Uma saída pode ser utilizada para várias atividades diferenciadas. Dessa forma pode-se conjugar as "tarefas" que os estudantes deverão realizar com as atividades de socialização e/ou percepção. Ora eles podem estar todos juntos assistindo a uma palestra, e depois em grupos entrevistando com pessoas, e num outro momento (numa atividade solo, por exemplo), cada um fazendo sua "síntese histórica" ou memória do dia.

"A compreensão deste mundo passa, evidentemente, pela compreensão das relações que ligam o ser humano ao seu meio ambiente. Não se trata de acrescentar uma nova disciplina a programas escolares já sobrecarregados, mas de reorganizar os ensinamentos de acordo com uma visão de conjunto dos laços que unem homens e mulheres ao meio ambiente, recorrendo às ciências da natureza e às ciências sociais (...) numa perspectiva de uma educação que se estenda ao longo de toda a vida" (Delors, 2000, p.47). 
A idéia de se implementar EM parece estar sintonizada com os quatro pilares da educação ${ }^{16}$ que constituem uma via do saber, pelos "múltiplos pontos de contato, de relacionamento e de permuta" entre eles:

"Aprender a conhecer, isto é, adquirir os instrumentos da compreensão; aprender a fazer, para poder agir sobre o meio envolvente; aprender a viver juntos, a fim de participar e cooperar com os outros em todas as atividades humanas; finalmente aprender a ser, via essencial que integra as três precedentes" (Delors, 2000, p.90).

Cada EM deve, portanto, ser minuciosamente planejado, organizado, detalhado, aproveitado, pois é único, experiência única, que "requer um gesto de interrupção" impossível de ser repetido. É um tempo de disponibilidade e abertura para o aprender sobre si mesmo, o outro, o mundo.

\subsubsection{Outros olhares sobre o tema}

Numa pesquisa com professores do ensino fundamental e médio em 174 escolas da rede pública da região de Campinas/SP, foram enviados questionários direcionados para professores das disciplinas Geografia, Ciências e Biologia, por estarem "mais associadas aos trabalhos de campo" (Pegoraro, 2000). Com relação à freqüência com que realizavam atividades de campo, este autor constatou que $73 \%$ dos entrevistados não realizam ou o fazem raramente. Apenas 1\% afirmou realizar muitas vezes, porém, nenhum afirmou utilizar regularmente essas atividades em seu trabalho.

É importante ressaltar as dificuldades que os professores apontaram como justificativas para a não realização das saídas: as questões econômicas e operacionais (locomoção) predominam, as dificuldades estruturais, como sobrecarga de horas aula, grande número de salas ou séries com muitos estudantes também foram apontadas.

O autor conclui que "atividades educativas de campo, EM e congêneres, ainda não integram, de forma sistemática e freqüente, o cotidiano das escolas públicas nas cidades onde o levantamento foi realizado" (Pegoraro, 2000, p.9). Os professores que afirmaram utilizar essas atividades, o fazem no entorno da escola, em locais bastante

${ }^{16}$ Delors, J. (2000) Educação um tesouro a descobrir. É o relatório para a UNESCO, da Comissão Internacional sobre Educação para o século XXI 
antropizados, ou ainda em zoológicos ou parque públicos. A utilização de tais espaços nos processos educativos merece algumas críticas, como por exemplo, com relação às condições de manutenção de animais (geralmente exóticos) em cativeiros, oferecendo um campo para aprofundar uma reflexão.

Outros autores, partindo de referenciais teóricos no campo da Educação Ambiental, afirmam que hoje se ampliaram e se diversificaram os proponentes de iniciativas na área. Destacando o que foi discutido nos últimos fóruns de Educação Ambiental, Sorrentino (1997), a partir de suas observações e experiências, procura interpretar os diversos fazeres educacionais voltados à questão ambiental, classificando-os em quatro grandes correntes: "conservacionista", "gestão ambiental", "economia ecológica" e "educação ao ar livre".

Com a primeira corrente, o autor refere-se aos movimentos que denunciam os impactos sobre a natureza; a "gestão ambiental" está atrelada aos movimentos sociais da América Latina, em resistência aos regimes autoritários e embates diversos; e a "economia ecológica" ligada às propostas de "ecodesenvolvimento", enunciadas por Sachs (1986) e Schumacher (1983).

Sobre a última corrente - "educação ao ar livre", Sorrentino (1997b) comenta que nos países do Norte há um número expressivo de adeptos com maior "consistência filosófica", pois associam os desafios das atividades junto à natureza com dinâmicas de grupo, estimulando-se o autoconhecimento e o "aprimoramento do fazer cotidiano, individual e social".

Ainda segundo Sorrentino (1997b) esses adeptos, no Brasil, podem ser representados através de:

“(..) antigos naturalistas, escoteiros e participantes de grupos de espeleologia, caminhadas, montanhismo, acampamentos e outras modalidades de esportes e lazer junto à natureza, ganhando uma dimensão assumidamente de Educação Ambiental, mais recentemente, com alguns grupos de "caminhadas ecológicas", "trilhas de interpretação da natureza", "turismo ecológico" e outros nomes" (Sorrentino, 1997b, p.49). 
Já Tamaio (2002) faz uma investigação detalhada visando associar atividades de campo aos processos educacionais. Nesse sentido, ressalta a importância do professor/educador, pois o seu papel deve ser de poder atuar como um sujeito histórico no processo de aprendizagem, na construção e compreensão do conhecimento, deixando de ser um mero formulador de informações. Afirma ainda que "o campo é o local da busca de conhecimentos mediados, de onde se extraem as informações para os questionamentos teóricos e construção de conceitos", contribuindo assim, "para a elaboração de conteúdos críticos na construção dos conceitos-chave em Educação Ambiental". No que se refere à aprendizagem, a observação da natureza quando mediatizada (por palavras e signos), "pode contribuir para o desenvolvimento da capacidade cognitiva estimulando a compreensão das questões ambientais" (Tamaio, 2002, p.93).

Com o intuito de se verificar a qualidade de reportagens de um veículo de comunicação da mídia impressa, destacou-se da "Revista Nova Escola"17, matérias e artigos sobre EM que foram realizados em diferentes regiões do País. O incentivo à realização desse tipo de atividade configura-se na necessidade de um novo olhar e uma nova forma de agir e interagir no ambiente, pois "el estúdio del médio conduce a uma toma de conciencia de la fragilidade de la biosfera y puede dar lugar em lãs jóvenes generaciones a um nuevo sentimiento de la naturaleza" (Debesse-Arviset 1985, p.171). O mesmo autor faz críticas à mass media $^{18}$ pois o jornal, o rádio, a televisão (e mais recentemente, a Internet) roubaram o interesse pela vida escolar, de modo geral e de disciplinas como a Geografia, em particular, por trazer com muita rapidez imagens que hipnotizam, que causam atração ou repulsão ${ }^{19}$. Se essas imagens podem aparecer na

\footnotetext{
${ }^{17}$ Revista da Editora Abril, específica para a área de Educação, da Fundação Victor Civita (entidade sem fins lucrativos - dedicada a apoiar, valorizar e qualificar o professor do ensino básico do Brasil), com publicação que circula desde 1986, com 520.000 exemplares/edição, 240.000 assinantes, sendo que 197.000 escolas públicas recebem gratuitamente 10 edições por ano. Seus objetivos para fornecer ao professor informações necessárias a um melhor desempenho do seu trabalho; valorizá-lo, integrá-lo ao processo de mudança do País, proporcionando troca de experiências e conhecimentos.

${ }_{10}^{18}$ Mídia de massa

19 Há dois conceitos difundidos por Tuan (1980), pois explicam as sensações quando nos deparamos com uma paisagem. O sentimento de 'topofilia' viria pelos laços afetivos dos seres humanos com o seu meio ambiente material e, que transmitem prazer e deleite. Ao contrário, 'topofobia' quando a sensação causada é desagradável, de repulsão ou até medo.
} 
sala de estar, na tela da TV ou do monitor do computador, elas não permitem a mesma percepção, reflexão, análise ou um estudo crítico como se estivéssemos presentes.

Através dessa revista específica para educadores, a pesquisa quantificou e qualificou matérias e artigos, editadas num período de 18 meses, entre 2001 e 2002. O objetivo foi de selecionar, sistematizar e analisar como são retratados EM no ambiente escolar. Havia a hipótese de que o veículo de comunicação Nova Escola abordaria, em reportagens específicas, as atividades de EM com clareza e explicitação dos conceitos científicos, valorizando e incentivando essa prática.

Resumidamente, a análise revelou que as matérias e artigos correspondem aos princípios de apoiar, valorizar e qualificar as atividades do professor, propostos pela editora. A revista parece tratar os conteúdos e as palavras-chave relacionadas às atividades de EM com adequação, de modo a confirmar a hipótese proposta, fazendose ressalva apenas à palavra preservação ${ }^{20}$, utilizada significando conservação.

Cabe ainda comentar que a análise preliminar do material impresso indicou que a revista incentiva práticas pedagógicas fora de sala de aula, de forma a contribuir com a construção da relação ensino-aprendizagem. Essa tendência de linha editorial parece ficar evidente também na qualidade do material fotográfico e nas ilustrações em geral, ambos utilizados na diagramação de outras reportagens, onde há a valorização do uso de espaços diferenciados e da realização de atividades fora de sala de aula mesmo não se tratando especificamente de EM. Portanto, essa revista pode ser considerada como um veículo importante para a divulgação de atividades extraclasse.

\subsubsection{Considerações finais sobre estudos do meio}

A importância de se realizar EM parece ser evidente pelo que foi exposto, ficando clara a sua contribuição para a melhoria da relação de ensino-aprendizagem, entre outros ganhos - objetivos e subjetivos. Mesmo diante disso, deve-se lembrar das dificuldades operacionais e curriculares nas escolas em realizar tais atividades.

Quando inserido num projeto político-pedagógico, o EM, levado a sério e bem estruturado, pode promover um contato entre os participantes, a realidade e o entorno

${ }^{20} \mathrm{O}$ conceito de preservação pressupõe que o acesso do ser humano às áreas naturais e também em algumas categorias específicas de unidades de conservação deve ser bastante restrito, sendo vetada a exploração de qualquer recurso natural. Ele é confundido normalmente com o de conservação que significa o uso sustentável dos recursos naturais. 
com a devida qualidade, já que o modo de vida contemporâneo nos afasta de uma percepção crítica.

Utilizados em plena função, os órgãos sensórios captam estímulos e dão um alerta, ou, em caso contrário, podem metaforicamente estar envoltos de "nuvens escuras", que "embotando-os", imobiliza e aliena os seres humanos. Os sentidos - tato, olfato, audição, paladar e visão - poderiam (e deveriam) servir como proteção ou defesa às agressões externas, mas também como aprendizado, deleite, contemplação.

Podendo ser realizado em espaço urbano ou não, ressalta-se a importância de se incentivar, no EM, a aproximação a ambientes menos antropizados, buscando-se também contemplação e fruição, pois contatos superficiais com a natureza, pouco têm de autênticos. A necessidade de aproximação e contato físico direto é reforçada por Tuan:

"Na vida moderna, o contato físico com o próprio meio ambiente natural é cada vez mais indireto e limitado a ocasiões especiais. Fora da decrescente população rural, o envolvimento do homem tecnológico com a natureza é mais recreacional do que vocacional. O circuito turístico, atrás das janelas de vidro raiban, separa o homem da natureza" (Tuan, 1980, p.110).

É importante lembrar que o conceito de natureza modifica-se em função, pelo menos, da cultura e do tempo; sendo fruto de uma construção que ainda está se processando na cultura ocidental, que ora a distancia, ora a aproxima do ser humano. Mesmo assim, dela somos parte intrínseca.

A realização de EM precisa ser estimulada, apesar das dificuldades econômicas, pedagógicas e estruturais hoje enfrentadas pelas instituições de ensino. É uma técnica que deve ter como premissa ensinar com responsabilidade, dinamismo, entusiasmo, resgatando-se o maravilhamento pelo aprender, pela vida. Outros autores ${ }^{21}$ chamamnos a atenção para a necessidade de um novo olhar/pensar - com profundidade - para a questão ambiental. Nesse sentido, a promoção e realização de EM, prática difundida

${ }^{21}$ Desde os naturalistas, em geral botânicos, do final do século XIX e início do século $\mathrm{XX}$, aos cientistas mais contemporâneos, como Capra (1982) e Leff (2001). 
nas escolas e de reconhecida utilidade, pode corroborar e contribuir para a construção de sociedades futuras, nas quais os sujeitos sintam-se pertencentes, inseridos num contexto socioeconômico e cultural, de maneira a se recuperar a dignidade humana e a qualidade de vida.

\subsection{Pertencimento}

"No momento que vivemos, marcado que é pelo desenraizamento e pela errância, precisamos buscar outros múltiplos níveis de encontro com estas forças criadoras da origem. Nesta procura, precisamos de uma dimensão de pensamento que não se apresse em enquadrar a realidade em esquemas pré-fabricados; uma postura existencial que se ponha à escuta da vida e de seus sinais" (Unger, 2001, p.138).

Numa perspectiva histórica, pode-se dizer que a Educação Ambiental está definitivamente, neste início do século $\mathrm{XXI}$, somando e convidando diversos setores socioeconômicos a repensarem o modelo de desenvolvimento preponderantemente hegemônico em que vivemos. Mais do que repensar, buscar novos paradigmas e atitudes transforma-se numa necessidade urgente para a sobrevivência, inclusive, da espécie humana.

Se, por um lado, a imposição desse modelo vem comprometendo os ciclos físicos, químicos e biológicos do planeta, desde os incrementos tecnológicos da revolução industrial, estendendo-se até a recente apologia ao consumismo; por outro, pode-se afirmar que o ideário ambientalista - em graus qualitativos e quantitativos variáveis - percorre, atualmente, escolas, indústrias, empresas e instituições públicas de toda ordem e em diferentes categorias.

Há, no entanto, necessidade de se revisitar algumas ocorrências da última metade de século $X X$, como pontos de convergência para essa reflexão que tem no seu centro a questão do "pertencimento" ou do "sentimento de pertença".

A importância do conceito de pertencimento explica-se na frágil relação do ser humano com o seu entorno, a partir do agravamento da crise ambiental na 
contemporaneidade, um desenraizamento que, supostamente, leva à não responsabilidade.

Outrora, muitas civilizações tiveram atitudes predatórias em relação aos recursos da natureza; além disso, ela foi temida por se acreditar que era morada de seres sobrenaturais. Esse "trânsito" pela compreensão e inserção do ser humano no ambiente natural tem graus variados. Diariamente, cientistas alertam na mídia, que nunca foi presenciada uma devastação tão voraz e, numa extensão global como agora.

Nesse sentido, pode-se afirmar que há também uma grave crise de percepção, ou seja, vive-se num estado de desconexão com a realidade espaço-temporal, associada à dificuldade de articulação política e social na busca de soluções responsáveis (preventivas, mitigadoras e compensatórias) para os desastres socioambientais.

Compreender a complexidade dessa problemática pode contribuir com processos que busquem emancipação e autonomia das sociedades, pois "a tomada de consciência de nossas raízes terrestres e de nosso destino planetário é uma condição necessária para realizar a humanidade e civilizar a Terra" (Morin, 2000, p.105).

A priori, esse conceito - pertencimento - pode nos remeter a, pelo menos, duas possibilidades $^{22}$ : uma vinculada ao sentimento por um espaço territorial, ligada, portanto, a uma realidade política, étnica, social e econômica, também conhecida como enraizamento; e outra, compreendida a partir do sentimento de inserção do sujeito sentir-se integrado a um todo maior, numa dimensão não apenas concreta, mas também abstrata e subjetiva.

\subsubsection{Enraizar ou pertencer}

Buscando trazer alguns elementos para a elucidação da idéia do pertencer enraizado a um sítio, um território, agregaram-se contribuições de Weil (2001) e Morin (2000) entre outros.

${ }^{22}$ Essas duas possibilidades devem permitir apenas o trânsito e o aprofundamento teórico sobre as perspectivas apontadas, pois crê-se que são complementares e indissociáveis. A contribuição desse exercício reflexivo se dá pela oportunidade de tratar de autores/filósofos com quem, cotidianamente, se tem pouco contato, já que a Filosofia foi suprimida, apartada, via de regra, da vida escolar. 
Para Weil ${ }^{23}$, enraizamento é difícil de definir, porém é uma necessidade tão importante quanto desconhecida da alma humana.

"Um ser humano tem raiz por sua participação real, ativa e natural na existência de uma coletividade que conserva vivos certos tesouros do passado e certos pressentimentos de futuro. Participação natural, (...) ocasionada (...) pelo lugar, nascimento, profissão, meio. Cada ser humano precisa ter múltiplas raízes. Precisa receber a quase totalidade de sua vida moral, intelectual, espiritual, por intermédio dos meios dos quais faz parte naturalmente" (Weil, 2001, p.43).

Ao contrário, o desenraizamento após uma conquista militar, deportação, dominação econômica, sob condição social do salariado ou camponês, e até sob o desemprego pode ser "uma doença quase mortal" pois desloca o ser humano das suas referências culturais. "As populações infelizes do continente europeu precisam de grandeza ainda mais do que de pão, e não há senão duas ordens de grandeza, a grandeza autêntica, que é de ordem espiritual, e a velha mentira da conquista do mundo" (Weil, 2001, p.91).

Nessa situação perigosa de um ser desenraizado politicamente, pode haver dois comportamentos possíveis para Weil: cair numa inércia da alma, equivalente a morte, como num sistema de escravidão; ou, atrair com métodos violentos aqueles que ainda não estão, ou pelo menos estão em parte, nesse estado.

Parece haver uma associação, de simultaneidade temporal, entre o desenraizamento e o aumento da brutalidade e violência contra o ser humano. Também as diferentes manifestações de depressão e pânico, vividas nas últimas décadas, principalmente nas grandes cidades podem ser efeito desta desconexão.

"As doenças mentais, a drogadição, as sociopatias como a criminalidade e a violência, a competição, a inveja, a gula, estão presentes em todas as classes sociais. O mesmo podemos dizer do amor, da esperança, do altruísmo, da solidariedade.

\footnotetext{
${ }^{23}$ No livro "O enraizamento" a autora apóia-se principalmente na História da França.
} 


\begin{abstract}
Sentimentos considerados positivos ou negativos não são privilégios desta ou daquela classe social, porém possibilidades incondicionais de cada ser humano" (Zago, 2004).
\end{abstract}

O autor, com experiência em clínica para dependentes químicos, relaciona drogadição ao problema do consumismo, pois nele há tendência de obter-se tudo pronto, "no sentido de que todos pensem a mesma coisa. Todos pensarem a mesma coisa é igual à não-pensar. Esse é o outro significado de adoecido existencialmente" (Zago, 2004).

Esta reflexão se aproxima ao niilismo ${ }^{24}$, como Nietzsche o entendeu, enquanto "um movimento ou processo histórico que, de raízes mergulhadas nos séculos anteriores, deverá determinar os séculos futuros. Sua essência consiste na morte de Deus e nas conseqüências dessa morte" ${ }^{25}$. Consta na Enciclopédia de Filosofia ${ }^{26}$ que segundo Nietzsche, niilismo é "o advento da consciência de que todos os fins e todos os valores que até então davam sentido à vida humana se tornaram caducos".

Essa discussão parece apropriada à conjuntura mundial atual de busca de novos paradigmas, da virtualidade da economia globalizada através das bolsas de valores, da velocidade vertiginosa da informação proporcionada pelo avanço tecnológico na informática, mas principalmente, sobre a dúvida se haverá um futuro comum para a humanidade.

"Assim constitui-se a teleparticipação planetária: as catástrofes que atingem nossos antípodas suscitam impulsos de compaixão fugazes e o sentimento de pertença à mesma comunidade de destino, doravante a do planeta Terra. Sentimo-nos planetários por flashes" (Morin, 2000, p.42).

Uma das conseqüências do modelo econômico "mundializado" foi que, a partir dos anos 50, houve uma seqüência de desastres ambientais que tiveram conseqüências que repercutiram por todo o planeta, podendo-se citar: a poluição

\footnotetext{
${ }^{24}$ Niilismo (do latim nihil, "nada") é uma doutrina filosófica e política baseada na negação de toda ordem social estabelecida.

${ }^{25}$ Trecho extraído da home page geocities.yahoo.com.br/mcrost07/nietzsche.htm - 14k (10 maio 2004)

${ }^{26}$ Com textos bastante introdutórios.
} 
atmosférica que matou milhares de pessoas em Londres, denominada por "smog"; a poluição por despejos industriais contendo mercúrio em Minamata (Japão), causando disfunções neurológicas diversas; testes com bombas de hidrogênio no atol de Biquíni, nos EUA, contaminando com radiação animais e plantas marinhas e, também, marinheiros, entre os acontecimentos mais graves.

Nas décadas seguintes, as catástrofes continuam: navios petroleiros derramando óleo cru pelos oceanos; vazamento de gás em Bhopal na Índia; acidente nuclear em Chernobyl na Ucrânia; redução da bacia do mar de Aral na Ásia; poluição do lago Baikal na Rússia e muitas outras, que têm seus flagelos transpondo fronteiras territoriais, pois, além de degradar o entorno, os seus efeitos são disseminados de forma encadeada seja pela água, terra e/ou ar.

Se a idéia de desenvolvimento que partiu da Europa no pós-guerra foi preponderante, ela veio rompendo com uma relação com o passado. Diferentes etnias e sociedades pelo mundo inteiro foram arrancadas de suas tradições, pois se acreditava estar avançando em direção a um futuro promissor e prometido.

"O progresso era identificado com a própria marcha da história humana e impulsionado pelos desenvolvimentos da ciência, da técnica, da razão. A perda da relação com o passado era substituída, compensada pelo ganho da marcha para o futuro" (Morin, 2000, p.79).

Ao mesmo tempo em que sociedades que se constituíram entrelaçadas com outras, vão perdendo autonomia e identidade, um novo sentido voltado para o progresso vai se constituindo num enraizamento étnico-religioso sobre a pátria, que é "um termo masculino/feminino que unifica em si o paterno e o materno" (Morin, 2000, p. 76).

Assim, o Estado oferecendo armas, autoridade, defesa, passa a conferir poder, devendo-se então obediência a ele. Nesse sentido, o sentimento de pertença pode ser expresso pela comunhão fraterna entre os "filhos da pátria", congregando indivíduos sem vínculo consangüíneo, que, no entanto, parecem querer restaurar "mitologicamente" a relação perdida com o lar protetor, o vínculo familiar ou tribal (Morin, 2000). 
O que vai se consolidando é a idéia - pouco confortável - de que os Estados e os seus problemas econômicos, de poluição, de tráfico de drogas, dos subprodutos da civilização tecno-industrial são transnacionais.

Intercalados nessa seqüência de desastres e catástrofes, desde os anos 60, vários movimentos sócio-culturais contribuíram para o surgimento e consolidação do chamado movimento ambientalista. Os hyppies, as feministas, os pacifistas, o cinema novo compunham cenários de contraponto aos modelos políticos e econômicos de opressão à liberdade, à qualidade de vida, aos direitos humanos. Nos anos 70, a fé na "tríade ciência/técnica/indústria" (Morin, 2000, p. 81) está abalada, pois é paradoxal. Dominar a energia nuclear não determina progresso humano, a produção industrial faz acumular resíduos, subprodutos tóxicos, poluições de diversas ordens, no entanto à época, a modernidade ainda promete.

"A modernidade comportava em seu seio a emancipação individual, a secularização geral dos valores, a diferenciação do verdadeiro, do belo, do bom. Mas doravante o individualismo significa não mais apenas autonomia e emancipação, significa também atomização e anonimato" (Morin, 2000, p. 81).

A secularização embute tanto a perda da influência da religião na vida social quanto a "angústia, dúvida, nostalgia das grandes certezas" (Morin, 2000, p. 81). Para Morin, essa diferenciação de valores resulta não só na autonomia moral ou na exaltação estética e busca da verdade, mas inclui a desmoralização, o esteticismo frívolo e o niilismo.

Assim, assumindo-se a ambivalência dos processos manifestados na modernidade ocidental, a crítica pode estar na incapacidade de se conceber um futuro. Apesar disso, ambientes de discussão sobre o futuro comum ${ }^{27}$ começam a coexistir, porém, alguns conflitos éticos podem ser depreendidos, a partir do sentimento de que o presente (e o futuro) está escapando das nossas mãos, escorre das mãos pelo menos a opção de um futuro digno e justo para as gerações futuras.

27 Alusão ao relatório "Nosso Futuro Comum" (1987), conhecido também, por "relatório Brundtland", no qual é definido o conceito de desenvolvimento sustentável. 
“Há inúmeras maneiras de se compreender o viver. Uma delas, e que reputamos básica, é o compromisso como ser-ao-mundo, entendido como a realização de nossa intersubjetividade - como sujeito-concreto que se desenvolve para a vida plena à medida que participa construtivamente para a elaboração da sociedade, e esta retorna para o próprio sujeito os ganhos comunitários" (Zago, 2004).

A noção - pobre e abstrata - de desenvolvimento, agregada à de progresso, de conforto, de consumo, "ignora os problemas humanos da identidade, da comunidade, da solidariedade, da cultura" (Morin, 2000, p. 83), além de trazer uma noção de subdesenvolvimento que também é pobre e abstrata, agravando as desigualdades entre os hemisférios. Pois, "também habitamos o mundo prosaicamente" Boff (2000, p.56), a situação que se apresenta, portanto, é objetiva e clama pela sobrevivência. Nesse sentido, o sentimento de pertença pode ser compreendido num sentido mais estrito, de competição; quando se manifestam conflitos étnicos, culturais, religiosos e mesmo de exclusão social. A privatização do espaço pode ser ocasionada também pelas diferenças "entendidas como a imagem do 'outro', a paisagem indesejável, por exemplo, que incomoda o nosso olhar" (Okamura, 2004, p.284). O que se constata é que perdeuse um referencial ético. Retomar essa questão para "insuflar uma inspiração a um povo Weil (2001)".

Portanto, é necessária uma ética do desenvolvimento, que não se preocupe com um final feliz para alguns, com certezas; pois temos, como nos ensina Morin (1995; 2000; 2003), que aprender a viver na incerteza, resgatando-se do passado o seu sentido telúrico, hominizante, humano.

Constrói-se a Ética a partir do acúmulo de saberes, de olhares, aprendendo e respeitando o passado que, segundo Weil (2001), é uma "necessidade vital da alma humana", sem hipertrofiar o presente; mesmo que o pensamento sobre o futuro seja como ele, incerto, porém, respeitando-se o direito à vida de todas as culturas, mesmo sabendo que elas se encontram, se modificam, se integram, tornando-se por isso mesmo, complexas (Morin, 2000). Com relação ao futuro, Weil (2001) diz que ele não 
nos traz nada e não dá nada, nós que temos de possuí-lo - vida, seiva, tesouros do passado - para construí-lo.

"Os sentimentos pessoais desempenham nos grandes acontecimentos do mundo um papel que nunca se discerne em toda sua extensão. O fato de que haja ou não amizade entre dois homens, entre dois meios humanos, pode em certos casos ser decisivo para o destino do gênero humano". (Weil, 2001, p.187).

A autora atribui à Educação, o objetivo, a incumbência de indicar o que é vantajoso, o que é obrigatório, o que é bom, destacando a necessidade de se conhecer uma "solução geral". Para se ter "noção" ao tratar um caso particular, é preciso instalar essa noção "permanentemente na alma, de maneira que ela esteja presente mesmo quando a atenção se volta para outra coisa" (Weil, 2001, p. 171). Assim é preciso ter no espírito noção de política pública para a educação do País.

Nesse sentido, educar para o pertencer, então, pode tornar-se parte de uma relação necessária, viva e saudável onde ao se resgatar passado e futuro, individual e coletivo, haja identificação e contribuição à realidade do presente. Para Morin (2000), "a renovação e a complexificação da relação passado/presente/futuro deveriam assim se inscrever como uma das finalidades da política de hominização" (Morin, 2000, p.115).

Segundo Morin (2000), esse "retorno às fontes do passado" acontecerá à medida que houver respeito aos princípios de "reconhecimento ao direito à vida para todas as culturas", com suas especificidades e insuficiências; lembrando que elas se modificam e até se tornam mais complexas ao incorporarem aquilo que antes as ameaçava. Mas não só: ele coloca que "é exatamente no presente que se dão as manifestações do viver que transcendem o desenvolvimento" (Morin, 2000, p.116).

O autor nos convida, ainda, para uma restauração do futuro possível, em que possa haver projeção, sem garantias de satisfação dos desejos, da realização das utopias. Relacionar "presente e futuro em suas dimensões utópicas (...) para se fazer história" (Tassara, 1998, p.21). 


\subsubsection{Pertencer e ser}

Para a segunda possibilidade, enunciada no início deste capítulo, do sentimento de pertença do ser humano integrado à natureza, do sujeito sentindo-se inserido e integrado a um todo maior, numa dimensão não apenas concreta, mas também subjetiva buscar-se-á inspiração principalmente em Unger (2001), Heidegger (1969; 1981) e Guattari (2000).

Nessa perspectiva, parece haver certa sintonia e analogia entre pertencimento e o pensamento filosófico-ontológico advindo do romantismo, do homem ligado à natureza, da reverente volta ao passado e, da reação de oposição ao pensamento mecanicista.

Baptista (2004) faz uma associação interessante entre o ideal romântico de fidelidade, à identidade e à memória ao sentimento de pertença:

"Estamos perante uma conciliação entre o ideal do romantismo de fidelidade a uma tradição e o ideal iluminista de afirmação da autonomia racional do homem. O humano define-se tanto pela capacidade de enraizamento a um lugar e a uma cultura, como pela capacidade de distanciamento e de critica em relação à natureza e a tudo quanto a tradição Ihe apresenta como natural." (Baptista, 2004).

A autora atribui à educação a promoção e gestão de um equilíbrio entre a mensagem do romantismo e a da modernidade. Nesse sentido, um exemplo interessante, de resgate de memória, é de Lochaber, distrito localizado nas TerrasAltas da Escócia. Trata-se de uma região de tradição gaélica, língua em vias de extinção utilizada por apenas $11 \%$ da população, na sua maioria idosa, que, no entanto, é importante para a identidade daquele povo que a ela está muito ligado. A revitalização do gaélico conta com o apoio financeiro da comunidade européia ${ }^{28}$ e está sendo promovida por vários grupos de ação local que pretendem reforçar o sentimento de pertença à região, transmitindo uma forte imagem daquela comunidade.

Eles pretendem rotular os produtos locais em gaélico, valorizando a cultura regional no seu conjunto: língua, música, patrimônio cultural, qualidade de vida das

\footnotetext{
${ }^{28}$ Para desenvolvimento de projetos de desenvolvimento rural
} 
comunidades, até desenvolver o "turismo de descoberta". A geração de empregos, em função disso, tem sido crescente, principalmente na educação, por solicitação de pais que querem que seus filhos aprendam a língua tradicional escocesa, contribuindo também para o aumento da solidariedade entre gerações.

Certamente, outros exemplos poderiam ser destacados, mas o que se pretende enfatizar é o olhar holístico que abrange as diferentes dimensões dos projetos: o resgate cultural, o ambiente natural, a participação e integração entre diferentes setores da sociedade em busca de valorizar a memória e o pertencimento, como anteriormente colocado por Baptista (2004).

Sabe-se, no entanto, que nem sempre isso ocorre e uma explicação pode vir com o pensamento de Unger (2001) de que há correlação entre a prepotência humana sobre a natureza e a busca de mais poder. "O projeto moderno de dominação da natureza está intimamente vinculado aos ritmos da sociedade industrial" (Unger, 2001, p.28). Todos têm igual poder sobre ela, podem dominar, controlar, assim a sociedade se desenvolve sob a ideologia do individualismo, valorizando o antropocentrismo.

"O empenho em reduzir todos os seres - o próprio homem incluído - à condição de objetos, cujo único valor consiste no lucro que podem produzir, acaba por provocar uma desertificação do mundo, tanto no sentido físico como no sentido anímico, espiritual. Na medida em que não mais se experiencia como parte integrante do Cosmo, mas como seu "mestre e senhor", o homem contemporâneo vive um desenraizamento fundamental, uma espécie de auto-exílio" (Unger, 2001, p.28-29).

Porém, no desenvolvimento do percurso da nossa civilização, sempre houve os que tinham uma outra visão de mundo; muitos cuidaram da vida através da reverência ao sagrado, mantendo uma escuta poética, com sabedoria vinda, muitas vezes, à margem das instituições (Unger, 2001). O romance "As Brumas de Avalon" (Bradley, 1989) retrata muito bem, através do olhar feminino, essa outra forma de estar na Terra. No entanto, há um momento de ruptura da reverência que o homem faz à natureza, o no qual é delimitado filosófica e historicamente.

"A expulsão do sagrado do Cosmo traz como conseqüência a progressiva divisão entre ciência e sagrado, entre conhecimento e 
sabedoria. Ora, em mundo dessacralizado torna-se um mundo passível de cálculo e manipulação pelo sujeito humano, visto daí em diante como centro ontológico do universo" (Unger, 2001, p.23).

"A bem dizer, desde uma antigüidade indeterminada, muito anterior ao cristianismo, até a segunda metade do Renascimento, foi sempre universalmente reconhecido que há um método nas coisas espirituais e em tudo que tem relação com o bem da alma. O domínio cada vez mais metódico que os homens exercem sobre a matéria desde o século XVI fê-los crer, por contraste, que as coisas da alma ou são arbitrárias, ou entregues a uma magia, à eficácia imediata das intenções e das palavras" (Weil, 2001, p.170).

A concepção de natureza e da inserção responsável do ser humano nela é diferente nas religiões, culturas e filosofias. Assim, ela pode ser compreendida como uma extensão do corpo humano, como por exemplo no taoísmo; ou numa visão antropocêntrica que valoriza o ser humano e coloca-o no centro, com o dever de subjugá-la.

"O cristianismo lembra ao ser humano que a autoridade que ele possa ter é sempre subordinada a uma autoridade mais alta e que a liberdade do homem não consiste em ele fazer o que bem entender, mas em adequar o seu querer a uma ordem mais alta (...)" (Unger, 2001, p.25).

Já numa visão sobre a evolução histórica, filosófica e biológica da natureza, vários autores discutem essa questão com posicionamentos e interpretações bastante diferenciadas, como Darwin (1985); Thomas, (1988); Schama (1996), entre outros.

Contribuições para uma reflexão poética sobre a vida também vieram através dos sonhos, do ser, do tempo, com Bachelar (1988;1989); Merleau-Ponty (1999; 2000); Heidegger (1969; 1981), entre outros. 
Outra idéia que parece agregar os sentidos para a questão do pertencimento vem da morada, da ambiência na natureza. E não seria a poesia uma forma de expressão pura e, portanto, verdadeira do sentimento de pertença?

"Entrementes, a consistência e o odor do carvalho começavam a falar, (...), da lentidão e da constância com que a árvore cresce. 0 carvalho mesmo assegurava que só semelhante crescer pode fundar o que dura e frutifica; que crescer significa: abrir-se à amplidão dos céus, mas também deitar raízes na obscuridade da terra; que tudo o que é verdadeiro e autêntico somente chega à maturidade se o homem for simultaneamente ambas as coisas: disponível ao apelo do mais alto céu e abrigado pela proteção da terra que oculta e produz" (Heidegger, 1969, p.68-69).

Pelas palavras metafóricas do filósofo-poeta, pode-se apreender a importância do que ele denomina "caminho do campo": a conquista pelo "Simples" na tranqüilidade, mas não a uniformidade entediante. "Os entediados só vêem monotonia ao seu redor. O Simples desvaneceu-se. Sua força silenciosa esgotou-se" (Heidegger, 1981, p. 70). Para este autor, o "caminho do campo desperta um sentido que ama o espaço livre e que, em momento oportuno, transfigura a própria aflição na serenidade derradeira" (Heidegger, 1981, p. 70).

Para o autor, "o Simples torna-se ainda mais simples. O que é sempre o Mesmo desenraiza e liberta" (Heidegger, 1981, p. 70). Ora, não estará contido nesta última frase um paradoxo/uma antítese sobre a reflexão da necessidade do pertencer? Então, enraizar seria prender, fixar? O enraizar não inclui a mesmice, e pode transcender, ao desenraizar. Parece um movimento, uma práxis voltada para a identidade. Se sinto-me pertencente, me liberto. Se enraízo, nutro-me do que há ali, criando minha identidade; posso então me libertar, ir para onde for, que meus referenciais estão claros, arraigados.

Continuando o pensamento inicial, o autor supera o plano supostamente oposto: "O apelo do caminho do campo é agora bem claro. É a alma que fala? Fala o mundo? Ou fala Deus?" (Heidegger, 1981, p.32). 
O sentido/sentimento de pertencer é apresentado num gradiente de relações (cuidado, solicitude, indiferença, interesse), por exemplo, entre o ser com ele mesmo, com os entes e as coisas.

"O ser-com-os-outros que se abre a partir de se fazer a mesma coisa com-os-outros não apenas se mantém dentro de limites exteriores, mas introduz os modos do afastamento e da reserva. O ser-com-os-outros que estão empregados para a mesma tarefa freqüentemente faz surgir apenas a desconfiança. Em outras palavras, quando pessoas se devotam à mesma tarefa comum, seu fazer é determinado pela maneira na qual, cada um em seu próprio modo, tem sido apropriado. Elas, então, tornam-se autenticamente presas juntas, e isto torna possível o justo modo de objetividade, que desvela o outro em sua liberdade para si mesmo" (Heidegger, 1981, p.42).

Continuando, "o ser-com-os-outros cotidiano mantém-se entre os dois extremos de solicitude - aquele que salta sobre o outro e o domina, e aquele que salta diante do outro e o liberta" (Heidegger, 1981p.42). No prefácio de "Todos nós ninguém”, Critelli (1981) traz a seguinte reflexão: ao pensar o tema Educação, "nos defrontamos com a relação homem-homem. O que primeiro enxergamos na educação é o 'homem-sendocom-os-outros-homens' de uma maneira particular" (Critelli ,1981, p.62).

Pertencer, no sentido de identificar-se com um lugar ou um espaço, fixar raízes, pode ir em direção à liberdade, autonomia, a um sentido ontológico frente à vida, ao entorno, as pessoas. Mas pertencer pode, também, estabelecer conflitos ao desencadear um sentimento de territorialidade que repele o diferente, e portanto, a diversidade.

"A possibilidade de uma implosão bárbara não está de jeito nenhum excluída. E se não houver tal retomada ecosófica (...), se não houver uma rearticulação dos três registros fundamentais da ecologia, podemos infelizmente pressagiar a escalada de todos os perigos: os do racismo, do fanatismo religioso, dos cismas nacionalitários caindo em fechamentos reacionários, os da 
exploração do trabalho das crianças, da opressão das mulheres..." (Guattari, 2000, p.16-17).

Guatarri (2000) não faz referência direta ao termo pertencimento, mas entendese aqui que o sentimento de pertença pode propiciar o enfrentamento e gerenciamento de conflitos, coadunando-se à proposta do autor da necessidade de haver uma consciência reflexiva que gere mudanças nos três pontos de vista das ecologias - da subjetividade individual e coletiva das relações sociais e do meio ambiente.

"Novas práticas sociais, novas práticas estéticas, novas práticas de si na relação com o outro, com o estrangeiro, com o estranho: todo um programa que parecerá bem distante das urgências do momento! E, no entanto, é exatamente na articulação: da subjetividade em estado nascente, do socius em estado mutante, do meio ambiente no ponto em que pode ser reinventado, que estará em jogo a saída das crises maiores da nossa época" (Guatarri, 2000, p.55).

"A experiência de estar no mundo, de morar, é a experiência do entrar em relação com a alteridade, com o sagrado; é a relação com a terra, com os outros, consigo, com o todo (...) não se trata de um saber desvinculado e abstrato, mas de um saber da experiência que está articulado a uma ética" (Unger, 2001, p.140141).

Essas perspectivas apontadas coadunam-se com a de Educação Ambiental defendida aqui, de ser libertadora enquanto promotora, em diferentes instâncias, de diversidade. Mesmo sendo utópica, pressupõe-se que onde há tolerância, as identidades e alteridades se instalam. Se tolerância, identidade e alteridade estão expressas aqui como subjetividades, sua concretude pode ser fomentada com os EM; como laboratórios, museus vivos das expressões mais diversas que o ser humano pode vir a ser, a realizar. 


\subsection{Olhares para a pesquisa qualitativa}

\subsubsection{Pesquisa quantitativa ou pesquisa qualitativa}

A utilização de diferentes metodologias de pesquisa em algumas áreas do conhecimento, principalmente na pesquisa social, é motivo de estudos, discussões e controvérsias entre pesquisadores. No entanto, pode-se afirmar que há um ponto que parece claro, definido, porém não definitivo: há predominância de metodologias quantitativas nas chamadas ciências duras ${ }^{29} \mathrm{e}$, ao contrário, nas humanidades ${ }^{30}$, usamse metodologias qualitativas para compreensão e interpretação dos fatos, da realidade.

Há certo antagonismo entre os modos de fazer ciências, no entanto, o que se pretende trazer aqui é uma reflexão a respeito das conseqüências disso e a atual crise socioambiental - compreendida como aguda e anunciada.

A Ciência, de maneira geral, deveria evoluir pelo menos nos dois últimos séculos, com os cientistas pensando na promoção, em última instância, de saúde e conforto para a humanidade. Porém, estamos vivendo um tempo em que parece ter se rompido "uma ordem natural das coisas", há uma crise e uma revisão de valores, de idéias e ideais.

Apesar da evolução histórica, tecnológica e conceitual observada, é como se algo tivesse saído errado. O conhecimento baseado preponderantemente no método científico, descrito principalmente por dois filósofos que viveram no século XVII, René Descartes e Francis Bacon, valoriza a indução, o teste, a observação e interpretação a partir de dados específicos e objetivos.

Uma característica dessa maneira de pensar e agir - cientificamente - é ver e fazer uso das coisas e pessoas, descartando suas subjetividades, fragmentando, como se fosse possível ao estudar as partes, compreender, conhecer o todo.

"A tradição cartesiana habituou-nos a desprender-nos do objeto: a atitude reflexiva purifica simultaneamente a noção comum do corpo e da alma, definindo o corpo como uma soma de partes sem interior, e a alma como um ser inteiramente presente em si mesmo, sem distância" (Merleau-Ponty, 1999, p.268).

\footnotetext{
${ }^{29}$ Em que há não só o predomínio de cálculos como a Matemática, Física, Química e Biologia, mas também um modo de fazer ciência.

${ }^{30}$ Como a Filosofia, Ciências Sociais, História.
} 
Nessa forma de ver o mundo, a natureza era, e ainda é, vista apenas como provedora de bens, dentro de um sistema econômico capitalista ou de supremacia da vontade humana sobre os recursos naturais. Tem-se atribuído a muitos dos problemas ambientais, a predominância da visão positivista em detrimento da expressão da subjetividade, do sentimento, da percepção humana sobre as coisas e pessoas.

Sendo assim, concorda-se com a proposta de se utilizar métodos qualitativos de investigação, como sugere Santos (2002), pois a pesquisa científica, balizada apenas pelo método quantitativo, reduz-se a um conhecimento insuficiente e contempla sumariamente a diversidade do "mundo vivido". Essa oposição ao método apenas quantitativo talvez seja um paradoxo para Becker (1999, p.14), quando afirma que "métodos qualitativos não são tão diferentes dos métodos quantitativos", já que os princípios subjacentes se aplicam às duas maneiras de trabalhar, assim como os dois tipos de sociólogos "tentam descobrir algo que valha a pena saber", contribuindo para a formação de uma base sobre o objeto de estudo, vindo a agregar com esse.

Sob outro enfoque, mas que também contribui para elucidar e circunscrever a pesquisa qualitativa, Minayo (1998) afirma:

"A pesquisa qualitativa responde a questões muito particulares. Ela se preocupa, nas ciências sociais, com um nível de realidade que não pode ser quantificado. Ou seja, ela trabalha com 0 universo de significados, motivos, aspirações, crenças, valores e atitudes, o que corresponde a um espaço mais profundo das relações, dos processos e dos fenômenos que não podem ser reduzidos à operacionalização de variáveis" Minayo (1998, p.2122).

Há uma diversidade de métodos que são utilizados para tais fins. Entre eles, Lüdke (2001, p.7) destaca quatro: a pesquisa participante, a pesquisa-ação, a pesquisa etnográfica e o estudo de caso. De maneira geral, eles ainda são fomentadores de discussão enquanto método, o que, ao invés de invalidar sua utilização, contribui para um maior rigor nos procedimentos adotados. Um rigor científico que não deve ser como aquele "fundado no rigor matemático", pois "é um rigor que quantifica e que, ao quantificar, desqualifica (...)" (Santos, 2002, p.32), perdendo em riqueza e escondendo 
os limites da nossa compreensão do mundo. Brandão comenta que "é preciso reconhecer que há muito mais procuras, ensaios e perguntas, do que respostas. Muito mais em experiências do que teorias consagradas" (Brandão 1999a, p.9).

Segue-se uma breve descrição dessas quatro abordagens qualitativas constantemente utilizadas em Educação; que, segundo Lüdke (2001), a pesquisa participante, a pesquisa-ação, a pesquisa de abordagem etnográfica e o estudo de caso. Com base em autores indicados por Lüdke (2001) e também em outros, apresentam-se abaixo as quatro categorias de pesquisa, acreditando-se que a explicitação de alguns dos seus fundamentos teóricos possam vir a contribuir para uma caracterização e/ou distinção entre elas, pois visam atender à demanda de pesquisa voltada à solução de problemas do cotidiano da Educação.

"Esses problemas, pela sua natureza específica, requerem técnicas de estudo também especialmente adequadas. Em lugar dos questionários aplicados a grandes amostras, ou dos coeficientes de correlação, típicos das análises experimentais, são utilizadas mais freqüentemente neste novo tipo de estudo a observação participante, que cola o pesquisador à realidade estudada; a entrevista, que permite um maior aprofundamento das informações obtidas; e a análise documental, que complementa os dados obtidos através da observação e da entrevista e que aponta novos aspectos da realidade pesquisada" (Lüdke, 2001, p.9).

\subsubsection{Pesquisa participante}

Brandão (1999a; 1999b), organizador dos livros "Pesquisa participante" e "Repensando a pesquisa participante", comenta que o educador Paulo Freire sugere, em seus primeiros textos sobre pesquisa participante (ou pesquisa alternativa), "caminhos e direções de pensamento sobre questões de estratégia e prática de trabalhos de investigação da realidade social, como base para um trabalho imediato de educação" (Brandão, 1999a, p.12).

Borda (1999, p.42-62) destaca seis princípios metodológicos da pesquisa participante, bem descritos para "grupos de base" ou de culturas distintas da forma 
dominante, portadoras de conhecimento empírico e que serviriam de base para as investigações do pesquisador. Dos princípios apontados pelo autor, destacam-se apenas três, que para não se perder o foco deste capítulo, serão expostos de forma sucinta. O primeiro princípio é o compromisso com a causa popular, de forma que a pesquisa demonstre "respeito pela cultura e filosofia do homem comum". O segundo trata do "feedback dialético"31, isto é, quando o processo político e pedagógico não apenas é restituído às bases, mas vem das bases aos intelectuais engajados, formando "grupos de consulta ad hoc, constituídos de camponeses idôneos, trabalhadores e índios com vasta experiência", a fim de suplantar os grupos de consulta, formados por acadêmicos em geral (Borda, 1999, p.53). Por fim, o terceiro princípio destacado, no qual essa articulação entre conhecimentos - "concreto com o geral, regional com o nacional" etc, deva se dar num ritmo específico no espaço e no tempo "que vai da ação à reflexão, e da reflexão à ação, em um novo nível de prática" (Borda, 1999, p.55).

Gormley (2001, p.13) ${ }^{32}$ destaca que a pesquisa participante teve seu início em meados de 1970, porém foi construída numa tradição de ciência já existente, a qual adota questões que envolvem justiça social. Segundo o mesmo autor, ela foi definida por Peter Park, Budd Hall, e também, Orlando Fals Borda que a denomina de pesquisa ação participativa. Em continuidade, comenta que derivações dessa podem acontecer, causando complicações, quando alguns autores passam a tratar da mesma coisa com nomes distintos ou dando nomes parecidos a coisas distintas. Cria, então, uma lista de características que deverão estar incluídas numa pesquisa participante, que têm sua ênfase no trabalho com comunidades carentes visando `a superação de adversidades. Ressalta assim as características desse tipo de pesquisa: os participantes interagem no método adotado pelos pesquisadores que passam a revisitá-lo; os pesquisadores envolvem os participantes em reuniões de grupo, refletem sobre suas necessidades, e há implementação de esforços no sentido de se "transformar os sistemas existentes em sistemas que forneçam igual acesso ao poder e a outros recursos" (Gormley, 2001,

${ }^{31}$ Quando comenta, neste ponto - da necessidade do "feedback dialético" - o autor agrega um outro conceito importante, trazido por Gramsci, do "intelectual orgânico", assim definido quando um agente obtém estímulo e conhecimento tanto de uma base empírica, popular, quanto de uma base científica.

${ }_{32} \mathrm{O}$ autor traz uma formulação sobre pesquisa participante, afirmando que ela é parte de uma experiência educacional com todos os envolvidos. 
p.3). Há de se considerar ainda como pertinente a "taxonomia da participação"33 na qual, segundo ele, o processo pedagógico das investigações é pouco discutido, bem como são diferentes as capacidades dos participantes em participar.

\subsubsection{Pesquisa-ação}

A pesquisa-ação foi, muitas vezes, confundida com a pesquisa participante e, segundo Thiollent (1985), não são sinônimos, pois pesquisa-ação supõe além da participação, "uma forma de ação planejada de caráter social, educacional, técnico ou outro". Numa das possíveis definições, o autor destaca que a pesquisa-ação é uma pesquisa com base empírica de uma situação/problema real, que se constitui como "um instrumento de trabalho e de investigação com grupos, instituições, coletividades de pequeno ou médio porte" e tem como principal objetivo possibilitar que pesquisadores e grupos envolvidos respondam "com maior eficiência aos problemas da situação em que vivem, em particular sob a forma de diretrizes de ação transformadora". Nessas circunstâncias, ela se torna inadequada para um enfoque "macrossocial" e também individual (Thiollent, 1985, p.9).

Já Barbier (1985) remete-se a ela - consubstanciado por autores como Lewin, Gramsci e Rapoport, entre outros - como uma pesquisa que visa contribuir tanto para o "alívio das preocupações de ordem prática das pessoas que estão em situação problemática", quanto "para o desenvolvimento das ciências sociais". Sendo, então, uma pesquisa cuja "gênese social precede a gênese teórica e metodológica" (Barbier 1985, p.38). Historicamente, o autor dá exemplos de como a sociologia americana surgiu a partir de problemáticas da "questão social", após a Primeira Guerra Mundial. A pesquisa-ação também se orientou para a solução de problemas sociais, principalmente após a Segunda Guerra Mundial, que podiam vir desde a qualificação de mão-de-obra até estimular o consumo de alimentos (como por exemplo, coração, rim ou tripas de boi)

${ }^{33}$ As considerações desta taxionomia referem-se a meios mais eficientes e efetivos para encaminhar assuntos. Na pesquisa desenvolvida por Gormley, o próprio grupo se descreveu em cinco categorias, conforme o grau de participação: "descansados, arrastados, andarilhos, corredores e alpinistas". E destaca: a importância de se identificar um "intérprete cultural" que não apenas traduza palavras, mas que faça emergir seu significado local; que na tomada de decisão deve-se prevenir o problema de "pensamento de grupo - groupthink"; a necessidade de uma "participação equilibrada e cinética" que considere o tempo necessário para o grupo desenvolver idéias e tomadas de decisão, mantendo o interesse; e, a importância de facilitar as reuniões de grupo para que seja flexível. 
tradicionalmente rejeitados pela população. O autor distingue quatro tipos de pesquisaação: diagnóstica, participante, empírica e experimental, que não serão aprofundadas neste capítulo, porém, uma perspectiva apontada nessa obra e que deve ser considerada nas reflexões é da "filosofia da práxis". Barbier $(1985$,$) descreve filosofia$ como "uma concepção de mundo, pelo menos em parte", e a ação veiculada "por uma concepção implícita de mundo" (Barbier 1985, p.52-53). A filosofia da práxis surge de uma "'sistematização' da concepção de mundo contida na ação", devendo-se tomar o cuidado para não se confundir com uma filosofia do senso comum, em que as concepção do mundo são absorvidas de forma acrítica pelos diferentes meios sociais e culturais.

\subsubsection{Pesquisa etnográfica}

Segundo André (1997) e Lüdke (2001), a abordagem etnográfica foi mais utilizada por antropólogos e sociólogos, sendo que, mais recentemente, a partir da década de 70 , pesquisadores da área educacional começaram a fazer uso dessas técnicas.

Lüdke (2001) destaca três questões que devem ser consideradas: as hipóteses, o método e o papel do observador. Com relação à hipótese entende-se que a pesquisa deve focar o indivíduo dentro do seu ambiente natural pois é "quase impossível entender o comportamento humano sem tentar entender o quadro referencial dentro do qual os indivíduos interpretam seus pensamentos, sentimentos e ações" Lüdke (2001, p.15). Quanto ao método, não há um seja recomendado como o melhor ou efetivo. Porém sugere as três etapas que, geralmente, o pesquisador desenvolve: "exploração, decisão e descoberta". Segundo Lüdke a investigação passa inicialmente por uma fase de seleção e definição de problemas, da linha teórica, dos públicos, dos locais, etc. Prossegue a fase de sistematização dos dados selecionados, que devem auxiliar na busca da compreensão e interpretação dos fenômenos estudados, visando descobrir as estruturas de significado dos participantes nas diferentes formas de expressão. Por fim, há a fase de explicação da realidade, de testar as hipóteses, de refinar as explicações teóricas, confrontando-as com as evidências positivas e negativas, a fim de minimizar o grau de inferência. 


\subsubsection{Estudo de caso}

Aqui será mais aprofundada que as outras metodologias já citadas, visto que esta pesquisa nela melhor se enquadra. Porém, deve-se ressaltar que cada experiência $^{34}$ é única, e em termos de método, cada um tem sua singularidade e, nos referenciais teóricos há bases para sua enunciação e compreensão, no entanto não se deve perder as especificidades dos caminhos trilhados.

Uma perspectiva da pesquisa social é que ela valoriza a interação entre pesquisadora e "membros das situações investigadas" (Thiollent, 1985, p.7). A caracterização de um estudo de caso, conforme Lüdke (2001), ocorre pelo seu caráter único, particular, singular, com valor em si mesmo, sendo também rica em dados descritivos, focalizando a realidade de forma complexa e contextualizada, podendo ser muito útil para conhecer e compreender melhor os problemas da escola, bem como suas relações com outras instituições. Pode-se destacar a caracterização do desenvolvimento de estudo de caso em três fases, que poderão se sobrepor nos diferentes momentos da pesquisa: a primeira seria a exploratória e de definição do objeto de estudo; a segunda mais de coleta e sistematização dos dados e informações; e, uma terceira de interpretação, análise e elaboração do relatório ${ }^{35}$.

Becker (1999) afirma que o termo "estudo de caso" refere-se, tradicionalmente, às análises detalhadas de um caso individual, voltado para explicações das dinâmicas de patologias da pesquisa médica e psicológica. Já adaptado e aplicado às ciências sociais, tem como objeto de estudo uma organização ou comunidade, porém, pode acontecer um estudo de caso individual, como por exemplo, uma história de vida.

Pra Minayo (1998), a técnica de observação participante se realiza através do contato direto do pesquisador com o fenômeno a ser observado, obtendo-se informações sobre a realidade dos atores sociais inseridos em seu próprio contexto. Para Becker (1999), um pesquisador que irá realizar um estudo de caso numa comunidade faz uso da observação participante e também de outras técnicas mais

\footnotetext{
${ }^{34}$ Segundo Bondía (2001), "a experiência é o que nos passa, o que nos acontece, o que nos toca". Pode expressar um saber distinto do saber científico e da informação, e uma práxis diversa daquela da técnica e do trabalho. O saber da experiência, a sua "mediação" ocorre na relação entre o conhecimento e a vida humana.

35 "Após um determinado período, o pesquisador pode preparar um relatório curto trazendo a análise de um determinado fato, a transcrição de uma entrevista" ou uma sessão de slides, um mural de fotos "mostrando algum aspecto interessante do estudo" de forma que se possa captar o que foi apreendido" (Lüdke, 2001.p.23).
} 
estruturadas, como as entrevistas. Yin (2003) sugere a observação direta; a observação participante e também o uso de artefatos físicos, como gravadores ou arquivos/acervos. Com relação à entrevista, Yin (2003) descreve três possibilidades: as abertas - para extrair fatos; as opiniões ou "insights"; e a focada - com perguntas previamente formuladas.

Essas ações que visam construir a base de dados, segundo Becker (1999), podem desencadear num conjunto de informações que não eram previstos no início do estudo, mas que podem contribuir para se compreender o grupo em estudo, seus membros, suas interações e correlações. Além disso, a pergunta explicitada pelo autor "como o grupo está relacionado com o resto do mundo?" - parece convergir com o propósito maior deste estudo, já comentado na introdução, de se contribuir para estimular e aprimorar ações coerentes e transformadoras, como por exemplo, através de uma "pedagogia planetária"36 voltada à formação de cidadãos críticos e atuantes, numa perspectiva de compreender e respeitar as conexões (visíveis e invisíveis) das experiências cotidianas, dos seres que habitam o planeta.

Yin (2003) afirma que um estudo de caso é uma pesquisa empírica que investiga um fenômeno contemporâneo, dentro de um contexto real, e deve nascer pelo desejo de se compreender um fenômeno social complexo. Ele sugere alguns componentes que devem fazer parte do "design da pesquisa", como por exemplo: uma questão de estudo do tipo como e/ou por quê?; ter proposições orientadoras do estudo, enunciadas de questões secundárias; determinar qual é a unidade de análise (um indivíduo, uma organização etc) e estabelecer critérios para interpretar os dados a partir de referencial teórico e categorias. Ainda sobre design, o autor comenta alguns critérios para se julgar sua qualidade, como o de buscar múltiplas fontes de evidência para uma mesma variável; testar a coerência interna entre as proposições iniciais, o desenvolvimento e os resultados encontrados; estabelecer coerência entre os achados do estudo e outros

\footnotetext{
${ }^{36}$ Vários autores trazem contribuições para essa reflexão, entre eles, Francisco Gutiérrez, Edgar Morin e Fritjof Capra. "Educar para a cidadania planetária supõe o desenvolvimento de novas capacidades, tais como: sentir, intuir, vibrar emocionalmente; imaginar, inventar, criar e recriar; relacionar e inter-conectar-se, auto-organizar-se; informar-se, comunicar-se, expressar-se; localizar, processar e utilizar a imensa informação da aldeia global; buscar causas e prever conseqüências; criticar, avaliar, sistematizar e tomar decisões" (Carta da Terra, 1999).
} 
resultados de estudos semelhantes; e, indicar sua confiabilidade, isto é, que ele pode ser repetido, obtendo-se resultados semelhantes e a partir de uma base de dados.

Uma outra perspectiva do autor e que converge para o presente estudo é que a construção ou o uso de 'categorias' deve ser buscado, pois as "análises orientadas por categorias já testadas em outros estudos, ou teoricamente fundamentadas oferecem qualidade ao trabalho" Minayo (1998, p.70-71). A autora refere-se à categoria como um conceito que abrange elementos ou aspectos com características comuns ou que podem se relacionar entre si.

Finalizando, cabe comentar que compete, em grande parte, ao pesquisador o sucesso de um estudo de caso. Vale citar a sua criatividade na proposição inicial, aos insights necessários à percepção da necessidade de reorientação da pesquisa. Sua experiência, perseverança e raciocínio crítico de investigador são apontados por Yin (2003) como importantes para se construir descrições, análises e interpretações de forma cuidadosa. Segundo Minayo (1998), há autores que fazem distinção entre as denominações "análise e interpretação"; a autora, no entanto, refere-se a elas num sentido mais amplo, isto é, uma abrangendo a outra, pois "estão contidas num mesmo movimento: o de olhar atentamente para os dados da pesquisa".

Numa reflexão sobre o conhecimento pós-moderno, Santos (2002) afirma que é "um conhecimento sobre as condições de possibilidade. As condições de possibilidade da acção humana projectada no mundo a partir de um espaço-tempo local. Um conhecimento desse tipo é relativamente imetódico, constitui-se a partir de uma pluralidade metodológica" (Santos, 2002, p.49).

Ele prossegue com uma crítica bastante pertinente, que vem contribuir para a "evolução" de metodologias qualitativas em pesquisas sociais, ao afirmar que "a ciência pós-moderna não segue um estilo unidimensional, facilmente identificável: o seu estilo é uma configuração de estilos construída segundo o critério e a imaginação pessoal do cientista" (Santos, 2002, p. 49).

Nesse sentido, também o olhar da multirreferencialidade (Barbosa, 1998) considera a metodologia como sendo: 
"um conjunto de procedimentos necessários no fazer e criar ciência, no entanto ela só é definida (enquanto fazer ciência) a posteriori, jamais a priori, sob a pena de conformismo. E deve sofrer, assim, transformações constantes, dialéticas e paradoxais, como um ser híbrido ou uma hidra (...) virtual e real tal a sua 'plasticidade e complexidade'" (Barbosa, 1998a, p.17).

Nas suas duas obras, "Reflexões em torno da abordagem multirreferencial" e "Multirreferencialidade nas ciências e na educação", Joaquim Barbosa (1998a, 1998b) destaca a contribuição de autores que se destacam nesse campo, tais como Burnham, Ardoino, Maffesoli, Barbier e Coulon, entre outros, que via de regra, parece convergir para propalar as idéias e ideais da complexidade de se estimular uma leitura plural dos significados, das linguagens e dos objetos, no sentido de vir a contribuir para encontrar caminhos alternativos e diferenciados de compreensão e solução dos problemas da contemporaneidade.

Para finalizar esse conjunto de conceitos e considerações acerca do método qualitativo na pesquisa científica em Educação, cabe ressaltar que os autores ora apresentados representam olhares e pensamentos críticos, em relação ao paradigma positivista, podendo gerar certo desconforto frente ao método tradicional de pesquisa quantitativa. Reafirma-se, então, a necessidade de investigações sobre o conhecimento e a pesquisa empírica, pois consideram as relações humanas em outras dimensões que a constituem, como a da subjetividade, de forma a contribuir com ações políticas voltadas à construção de sociedades mais justas e igualitárias, onde a ética possa percorrer fronteiras dessa construção maior que é o conhecimento sobre a humanidade.

A posição que se defende, portanto, é a de que a utilização do método qualitativo ou quantitativo pode e deve ser complementar, importando muito mais as análises e as evidências que venham a corroborar para a evolução do conhecimento científico, do que a restrição pela opção por um deles. 


\section{METODOLOGIA}

\subsection{Breve memória de um curso piloto}

\subsubsection{O cenário}

Ao iniciar no programa de mestrado em Recursos Florestais, a pesquisadora tinha a intenção de montar um curso a distância sobre estudo do meio para educadores que tivessem poucos recursos didáticos à disposição. Ao amadurecer a idéia junto ao orientador, concluiu-se que poderia ser oferecido um curso maior, não de extensão, mas sim de especialização. Esse primórdio fez ressurgir um ideal antigo desse professor de implementar um curso de Educação Ambiental diferenciado, com várias "portas de entrada"37e uma proposta pedagógica arrojada e desalienante, que pudesse contribuir com a formação continuada de educadores.

A partir de então, um grupo formado por seis pessoas - o professor, profissionais graduados e estudantes de pós-graduação - começou a se reunir freqüentemente para verificar o estado da arte dos cursos de Educação Ambiental. Chegou-se à conclusão de que a qualidade e a oferta de cursos de especialização nesta área era insatisfatória, tendo em vista a demanda de formação de educadores ambientais.

A equipe de coordenação colegiada consolidou-se, iniciando o trabalho de planejar um curso que atendesse à demanda de formação de formadores de agentes de Educação Ambiental, visando contemplar também algumas especificidades emergentes, em especial as intervenções educacionais nos espaços socioambientais.

Começou-se a pensar nos docentes que tivessem uma atuação destacada na área, oferecendo disciplinas, mas que também incorporassem a proposta pedagógica

${ }^{37}$ Respeitando os processos idiossincráticos, as trajetórias preliminares dos estudantes e oferecendo estudos dirigidos, propostas de projetos e de intervenções educacionais diversificadas que se coadunassem com os interesses de cada um. Cada estudante entraria no processo pelas portas que mais a motivasse. 
do curso, desempenhando ainda o papel de tutor/orientador dos projetos de intervenção educacional.

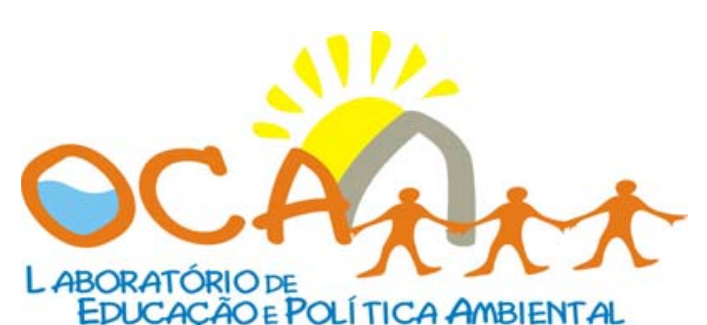

Assim, entre setembro de 2000 e julho de 2001, o Laboratório de Educação e Política Ambiental (OCA) do Departamento de Ciências Florestais /ESALQ /USP Piracicaba/SP, desenvolveu, realizou e implementou um programa de formação de especialistas ${ }^{38}$, comprometido com a construção de uma práxis de Educação Ambiental inserida na realidade brasileira.

Durante sua realização, promoveu-se um cardápio de disciplinas e atividades visando colocar em discussão a complexidade das problemáticas socioambientais da contemporaneidade.

Vale lembrar dois princípios do Tratado (1992) sistematizados na Rio 92 que nortearam o plano do curso: i) "A educação é um direito de todos; somos todos aprendizes e educadores" e, ii) "A Educação Ambiental deve integrar conhecimentos, aptidões, valores, atitudes e ações. Deve converter cada oportunidade em experiências educativas de sociedades sustentáveis".

Essa iniciativa (cópia do folder no Anexo B) denominada "Formação de educadores ambientais para sociedades CURSO DE ESPECIALIZAÇĀO sustentáveis" foi promovida pelo IPEF - Instituto de Pesquisa e Estudos Florestais, com o apoio da ESALQ - Escola Superior de Agricultura "Luiz de Queiroz", e com um pequeno apoio da VCP Votorantin Celulose e Papel, Secretaria de Estado PRESENCIAL E A DISTÂNCIA da Educação/CEl/Diretoria de Ensino, Região de Piracicaba e CEETPS - Centro estadual de educação tecnológica Paula Souza.

Pretendia-se encontrar um público-alvo de profissionais da Educação e/ou Meio Ambiente, interessado em se qualificar para a realização de projetos de Educação Ambiental voltados para a transformação sustentável da sociedade.

${ }^{38}$ Com a colaboração de: Mauríco Marcon, Luciana Jacob e Maria de Lourdes Spazziani. 


\subsubsection{A proposta pedagógica}

Inspirou-se, inicialmente, nas discussões e nos posicionamentos de autores como Freire (2000), principalmente na obra "Pedagogia da Autonomia", e em Morin (2000), com "Os 7 saberes necessários à Educação do Futuro" ao conceber um curso de especialização que pudesse contribuir para a: i) resolução de problemas socioambientais emergentes; ii) construção de Agendas XXI locais; iii) formação de grupos de cidadania ativa; iv) efetiva implantação de projetos de Educação Ambiental nas escolas (dialogando com os PCN), nos meios de comunicação e instâncias de educação cotidiana da população; e v) compreensão e aprofundamento nos conceitos e propostas do ambientalismo, enquanto ciência, movimento histórico-social e filosofia.

Essa abordagem contrapunha-se aos processos pedagógicos dominantes nas práticas educacionais encontradas nos vários níveis de ensino no Brasil. Práticas essas que, geralmente, se apresentam respaldadas numa concepção de construção de conhecimento que se caracteriza por ser asséptica, distanciada da experiência, da realidade, dos interesses e das capacidades dos estudantes em interagir positivamente em suas relações sociais.

Nesse sentido, buscou-se também respeitar e fomentar os posicionamentos individuais e coletivos, de modo a promover processos participativos para o desenvolvimento da autonomia e emancipação, contribuindo para a construção de comunidades de aprendizagem.

\subsubsection{A estrutura}

Durante os onze meses de duração, o curso teve carga horária total de 720 horas subdivididas da seguinte forma: i) 360 horas presenciais em dez encontros, sendo que três deles eram "concentrados" (duração média de 60 horas) e os sete outros eram menores, de 15 horas cada; além de algumas atividades extras como palestras e minicursos; e ii) 360 horas a distância (Belloni,2001): com atividades divididas entre estudo individual, em grupo, pesquisa, produção de trabalhos, chat (bate-papo), groupware (lista de dicussão) para a construção e realização do eixo articulador do curso - o projeto de intervenção educacional.

A comunicação eletrônica foi realizada com o apoio da CECAE/USP Coordenadoria Executiva de Cooperação Universitária e de Atividades Especiais e da RITS - Rede de informações do terceiro setor. 
O curso foi organizado em três módulos: estruturante, informativo e intervenção. O módulo estruturante constou de um conjunto de atividades que teve por objetivo estruturar o grupo como comunidade de aprendizagem; o módulo informativo foi desenvolvido através de um conjunto de disciplinas para fundamentar teórica e metodologicamente os projetos de intervenção educacional com as seguintes temáticas:

* Técnicas de elaboração de projetos (prof ${ }^{a}$. Gabriela Prioli);

* Ferramentas no uso do ensino à distância (prof ${ }^{\text {as }}$. Cristina Guarnieri e Sandra Lestinge);

* A formação de educadores (prof ${ }^{a}$. Margareth Brandini Park);

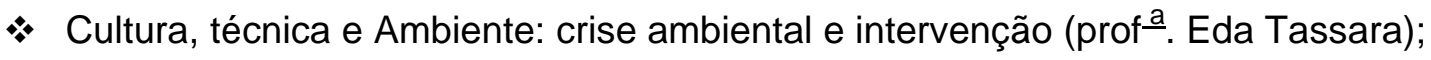

* Desenvolvimento humano e processos de conhecimento e de aprendizado (prof ${ }^{\text {a }}$. Maria de Lourdes Spazziani);

* Ambientalismo, contemporaneidade e Educação Ambiental (prof. Marcos Sorrentino);

* Re-conhecendo o meio ambiente (prof ${ }^{\mathrm{a}}$ Sandra Lestinge);

* Conflitos sócio-ambientais (prof ${ }^{\mathrm{a}}$ Lucia da Costa Ferreira);

* O olhar da cultura sobre a natureza" (prof. Carlos Rodrigues Brandão);

* O pensar, o sentir e o querer (prof ${ }^{\mathrm{a}}$ Ondalva Serrano).

Houve também outras participações e palestras com os seguintes educadores: Mirian Duailibi, Raquel Trajber, Luiz Ferraro, Fabio Cascino, Luis Afonso Vaz de Figueiredo, Samira Crespo e Moacir Gadotti.

O módulo de intervenção foi organizado de modo a propiciar ao aluno a realização e execução de um projeto nas suas diferentes etapas: diagnóstico, pesquisa de campo, a intervenção propriamente dita e a avaliação. Cada estudante teve um tutor que o acompanhou e orientou nas diferentes etapas. Buscou-se conciliar as áreas de atuação desses tutores com as problemáticas dos projetos de intervenção.

Com o curso já iniciado, os docentes foram convidados a integrar também um Conselho que foi constituído, a fim de que pudessem contribuir com discussões e reflexões que iluminassem a práxis da coordenação colegiada nesse projeto piloto. 
Cabe destacar que, nas comunicações entre coordenação e docente, que antecediam os encontros, eram enfatizados alguns diferenciais do curso: a comunicação eletrônica, a perspectiva de construção de comunidades de aprendizagem e a promoção de oportunidades de aprendizagem.

Pode-se afirmar que os docentes compreendiam e compactuavam com essas premissas, mesmo que alguns tivessem de enfrentar, na ocasião, os desafios da comunicação eletrônica e do ensino a distância, prática que vem se desenvolvendo nos diferentes níveis de ensino nos últimos anos (Neves, A. e Cunha Filho, 2000; Belloni, 2001).

\subsubsection{Perfil dos atores discentes}

No período de seleção dos interessados houve um total de 60 inscritos, dos quais, 36 selecionados e, finalmente, 33 matriculados que iniciaram o curso. Foram utilizados os dados de 29 deles, tanto para a apresentação do perfil, quanto dos resultados. Os dados dos outros foram desconsiderados por terem desistido logo no início do curso.

Entre os matriculados, 24 estudantes concluíram a especialização, os chamados egressos. Isso equivaleu a 72\%, aproximadamente.

A questão de gênero é representada por, aproximadamente, 27\% de homens, no início do curso, e $20 \%$ ao final. As mulheres representavam aproximadamente $73 \%$ do total, no início do curso, e $80 \%$ ao final.

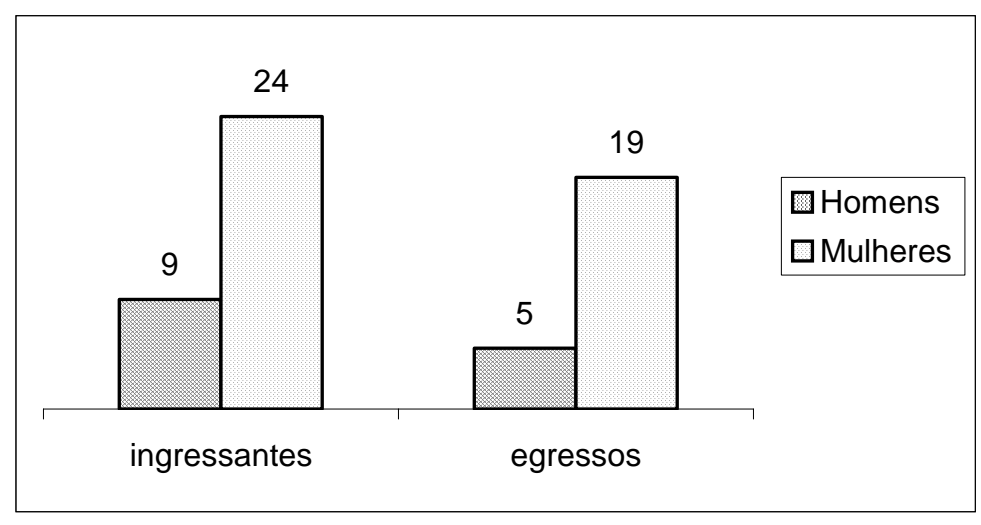

Figura 1 - Distribuição por gênero 
Para apresentar outras características dos ingressantes destacou-se, na Tabela 1, o local de origem, a idade, o gênero, a formação e a atuação profissional. Os dados referem-se aos declarados em setembro de 2000. A formação acadêmica entre eles era bastante diversificada, sendo que os dados apresentados na Tabela 1 permitem afirmar que há predominância de estudantes com formação em Ciências Biológicas, cerca de $34,5 \%$ do total. Entre as outras áreas de formação, destaca-se a presença de duas profissionais da saúde. Aproximadamente 50\% deles declararam exercer atividades formais ou não formais - em Educação.

Tabela 1. Perfil dos discentes

\begin{tabular}{|c|c|c|c|c|c|}
\hline & $\begin{array}{l}\text { Local de } \\
\text { Origem }\end{array}$ & Idade & Gênero & Formação & $\begin{array}{l}\text { Atuação } \\
\text { profissional }\end{array}$ \\
\hline Apus & Mogi-Guaçu/SP & - & $\mathrm{F}$ & Ciênc.Biológicas & Professora \\
\hline Aquila & São Paulo/SP & - & $\mathrm{M}$ & Eng. Civil & Eng. Civil \\
\hline Auriga & Hortolândia/SP & 30 & $\mathrm{~F}$ & Pedagogia & Pedagoga \\
\hline Capricornus & Piracicaba/SP & 36 & $\mathrm{~F}$ & Ciênc.Biológicas & Professora \\
\hline Carina & Vinhedo/SP & - & $\mathrm{F}$ & Arquitetura & Arquiteta \\
\hline Cassiopeia & São Paulo/SP & 23 & $\mathrm{~F}$ & Direito & Consultora jurídica \\
\hline Centaurus & Brasília/DF & 31 & $\mathrm{M}$ & Jornalismo & Repórter \\
\hline Cetus & São Paulo/SP & 27 & $\mathrm{M}$ & Ciênc.Biológicas & Diretor de projetos \\
\hline Chamaeleon & Piracicaba/SP & 40 & $\mathrm{~F}$ & Odontologia & Dentista \\
\hline Circinus & Piracicaba/SP & 27 & $\mathrm{~F}$ & Odontologia & Administração \\
\hline Columba & São Paulo/SP & 26 & $\mathrm{~F}$ & Eng. Florestal & Eng. Florestal \\
\hline Corona & S. André/SP & 21 & $\mathrm{~F}$ & Ciênc.Biológicas & Professora \\
\hline Corvus & Piracicaba/SP & 28 & M & Adm. Rural & - \\
\hline Crater & Piracicaba/SP & 23 & $\mathrm{~F}$ & Ciênc.Biológicas & - \\
\hline Crux & Piracicaba/SP & 39 & $\mathrm{~F}$ & Pedagogia & Supervisora escolar \\
\hline Cygnus & Hortolândia/SP & 27 & $\mathrm{~F}$ & Ciênc.Biológicas & Educ. ambiental \\
\hline Delphinus & Itaúnas/ES & 27 & $\mathrm{~F}$ & Eng.Agronômica & Diretora \\
\hline Draco & Piracicaba/SP & 28 & $\mathrm{M}$ & Eng. Agronômica & Eng. Agrônomo \\
\hline Equuleus & Piracicaba/SP & 28 & $\mathrm{~F}$ & Pedagogia & Pedagoga \\
\hline Fornax & Piracicaba/SP & 35 & $\mathrm{~F}$ & Pedagogia & Diretora de escola \\
\hline Gemini & Piracicaba/SP & 39 & $\mathrm{~F}$ & Tec. Química & Química \\
\hline Grus & Londrina/PR & 35 & M & Ciênc.Biológicas & Professor \\
\hline Hercules & São Paulo/SP & 36 & $\mathrm{M}$ & Ciênc.Biológicas & Professor \\
\hline Horologium & Piracicaba/SP & 36 & $\mathrm{~F}$ & Geografia & Professora \\
\hline Hydra & Campinas/SP & 25 & $\mathrm{~F}$ & Ciênc.Biológicas & Professora \\
\hline Indus & São Paulo/SP & 26 & $\mathrm{~F}$ & Ciênc.Biológicas & Autônoma \\
\hline Lyra & Piracicaba/SP & 27 & $\mathrm{~F}$ & Ciênc. Comput. & Professora \\
\hline Phoenix & São Paulo/SP & 32 & $\mathrm{~F}$ & História & Professora \\
\hline Taurus & Campinas/SP & 44 & $\mathrm{M}$ & História & Gerente comercial \\
\hline
\end{tabular}


A distribuição por faixa etária entre os ingressantes é uniforme entre os que têm até 30 anos e os que têm entre 30 e 40 anos, somando 84\% aproximadamente; os que têm mais de 40 anos perfazem 15\%.

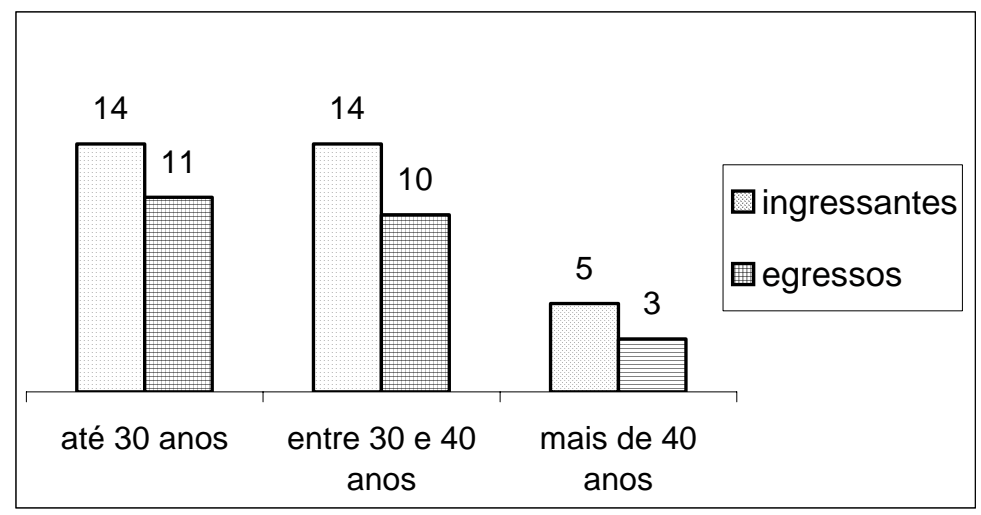

Figura 2 - Distribuição por faixa etária

Quanto à origem, pode-se afirmar que, aproximadamente, 48\% deles são de Piracicaba e região; 30\% provêm de São Paulo e do ABC; no entanto, destacam-se 12\% de outros Estados: Espírito Santo, Brasília (DF), Paraná e Minas Gerais.

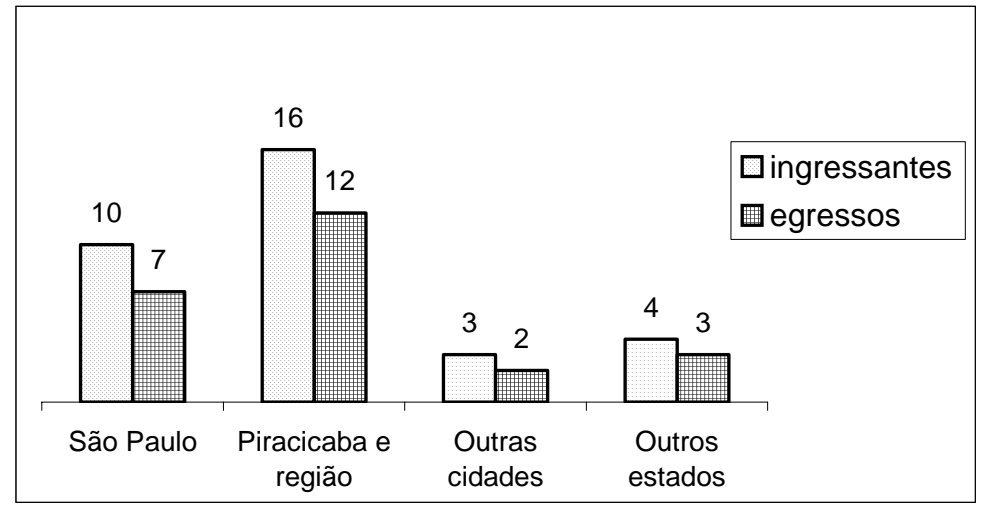

Figura 3 - Locais de origem

\subsubsection{O primeiro encontro concentrado}

Nas reuniões preparatórias, que antecederam ao início do curso, discutiu-se que, se ele começasse de forma tradicional (apresentação da turma, das disciplinas, dos conteúdos, do corpo docente, etc.) seria difícil depois, no seu decorrer, que eles 
encarnassem a proposta pedagógica diferenciada, isto é, de promover a mudança de olhar e de posicionamento frente às questões educacionais e ambientais e a responsabilidade pelo processo de aprendizagem individual e coletivo. Causar um impacto inicial, com uma dinâmica própria, era fundamental.

Sendo assim, várias atividades foram preparadas de forma a possibilitar a expressão de sentimentos, sensações, opiniões, linguagens que vieram alimentar muitas discussões que ocorreram durante todo o curso, conforme se constatou posteriormente.

Realizou-se o primeiro encontro, entre os dias 06 e 10 de setembro de 2000, com os 33 ingressantes matriculados. A programação desse encontro foi bastante intensa e teve mais de 40h de duração, com uma seqüência de atividades pedagógicas e culturais visando proporcionar aos estudantes, momentos para refletirem e se expressarem sobre as questões ambientais da atualidade.

$\mathrm{Na}$ seqüência de atividades realizadas no primeiro dia, os estudantes percorreram diferentes "salas de aula", representando afinal, um grande labirinto desde o ponto zero até a sala de mapa mental.

Selecionaram-se quatro atividades para discorrer: i) ponto zero, ii) sala do codinome, iii) labirinto da contemporaneidade e caminho dos sentidos e iv) sala do mapa mental, que caracterizavam a intenção desse primeiro encontro, além de contribuírem para a pesquisa.

i) Ponto zero: elaborou-se um questionário (Anexo C) para identificar quais eram as expectativas em relação ao curso e qual era o conhecimento e compreensão sobre estudo do meio. A necessidade desse momento era de obter os primeiros dados para esta pesquisa, coletados sem a interferência do curso. Os ingressantes, após chegarem ao Departamento de Ciências Florestais da ESALQ/USP e confirmarem sua matrícula, foram encaminhados diretamente ao auditório para responderem algumas questões. Por várias vezes durante e após o curso, esse momento foi lembrado por eles, pois imprimiu um caráter avaliativo, de ser uma "prova" sobre estudo do meio: "será que o curso é só sobre estudo do meio?"

Com relação às expectativas, em geral, pode-se afirmar que eram as de aprofundar conhecimentos teóricos e práticos, trocar informações e conhecimentos, capacitar-se e também a outras pessoas e, elaborar projetos. Traziam indagações, como por exemplo: "A cada ano que passa, percebo que o "bicho homem" só sabe 
retirar o que a natureza nos dá e oferece, mas infelizmente não a trata bem para preservá-la. O que será do futuro de seres que ainda estão por vir?"

ii) Sala do codinome: saindo do auditório, cada pessoa foi encaminhada individualmente para uma sala de aula com alguns materiais à disposição: canetas, etiquetas, uma cesta com frutas, peças de indumentária, etc. Havia ainda uma câmara de vídeo montada com fita SVHS, ligada e focalizada. Ao lado, foi colocado um cartaz que orientava alguns procedimentos: dar-se um codinome, escrevê-lo na etiqueta, colar na roupa e transmitir uma mensagem que estaria sendo gravada no vídeo. Posteriormente, editou-se uma fita de vídeo em VHS, que Ihes foi apresentada em outro encontro presencial.

Algumas das falas gravadas na "sala do codinome" que foram selecionadas e transcritas:

"Durante toda a minha vida eu sempre fiz coisas relacionadas à qualidade de vida, ao meio ambiente, sem saber que dos anos 90 para cá tivesse esse boom de preocupação".

"Gente! Vamos prestar atenção no planeta Terra, que a coisa está feia!"

"É engraçado a força que as coisas parecem ter quando elas precisam acontecer".

"Educação é a base de sustentação da humanidade. A Educação Ambiental é a base de sustentação do ecossistema".

"Eu sou professor (...) de certa maneira somos considerados operários de transmissão de conhecimento, né? Estou aqui para aprender a usar novas argamassas e tijolos para construir um conhecimento novo e mudar os conjuntos habitacionais, construindo algumas mansões de conhecimento".

Apesar da diversidade de expressões, pode-se perceber que há uma preocupação e uma vontade sincera de ir em busca de algo que aponte para um caminho novo. Seria uma saída para a crise da Educação?

iii) Labirinto da contemporaneidade e caminho dos sentidos: em uma sala de aula subdividida com plástico preto foram criados vários ambientes diferenciados, de modo a formar um labirinto (como se fossem "núcleos de tensão"). A utilização de 
labirintos, segundo Lee (1977), consiste em um campo de investigação na psicologia social de pesquisadores como, por exemplo, Lewin, Piaget, Gibson entre outros (Lee, 1977, p.135-139). A instalação iniciava por um corredor com muitas fotos coloridas (anúncios de revistas sobre moda e consumo) sobrecarregando o visual, no final do corredor, havia vários painéis com fotos em preto e branco do fotógrafo Sebastião Salgado. Ao fundo desse corredor, um vídeo passava sempre um mesmo clip da MTV. Desse ambiente saía outro, com um computador e um formulário contínuo enorme, aberto, com poesias escritas já meio apagadas no papel amarelado.
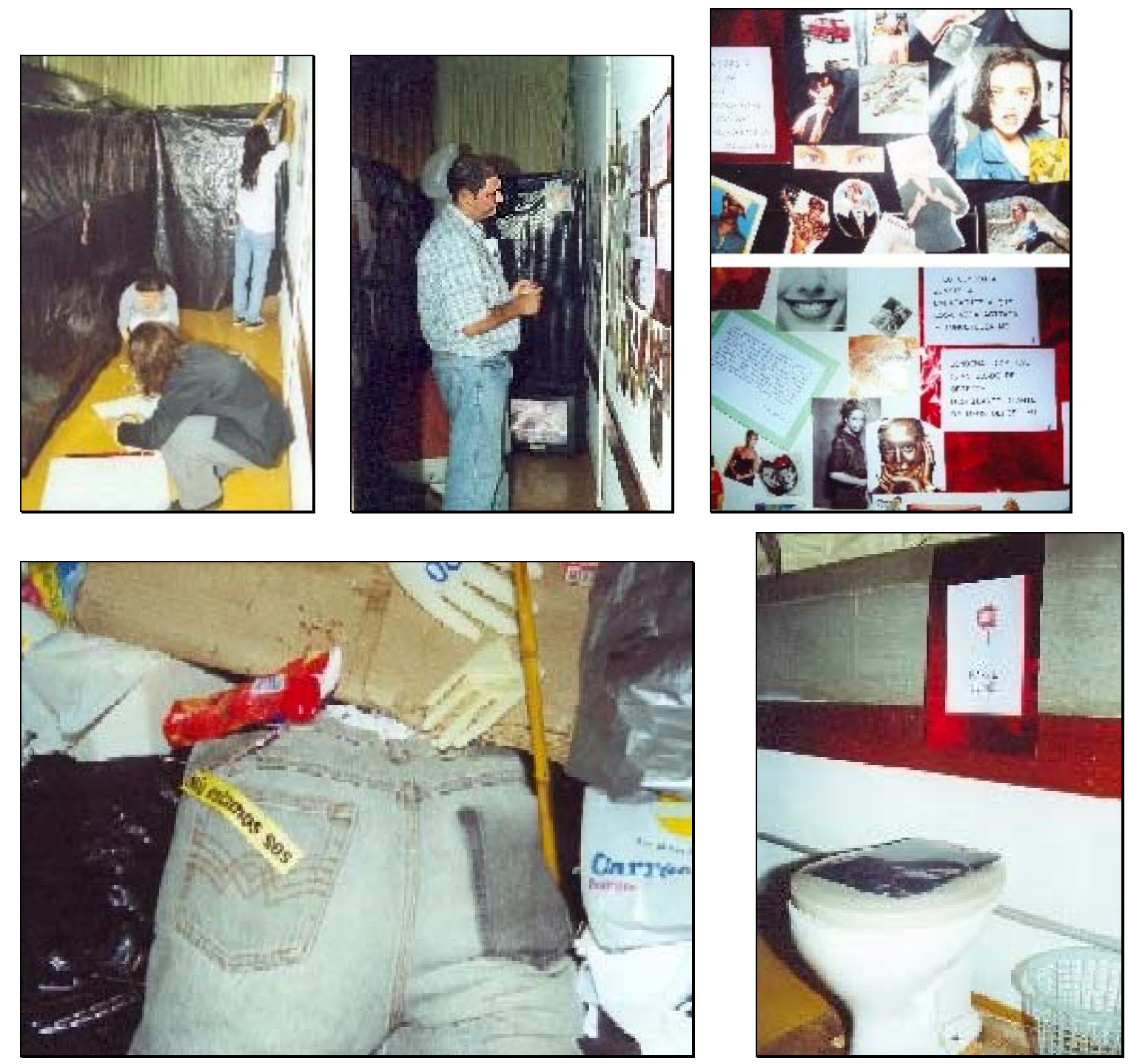

Figura 4 - Seqüências do labirinto 
A seguir, havia um local com um vaso sanitário fechado com tampa onde era possível sentar-se em frente a um armário. Na porta do armário estava escrito: "abra", e, ao se abrir a porta, havia um pequeno cartaz: "sorria, você está sendo filmado".

Ao sair do labirinto cada ingressante tinha os olhos vendados e era conduzido por um "caminho dos sentidos". A intenção de provocar "tensões" parece que surtiu efeito para eles, pois, foi relembrado muitas vezes durante o curso, também, como um momento "assustador".
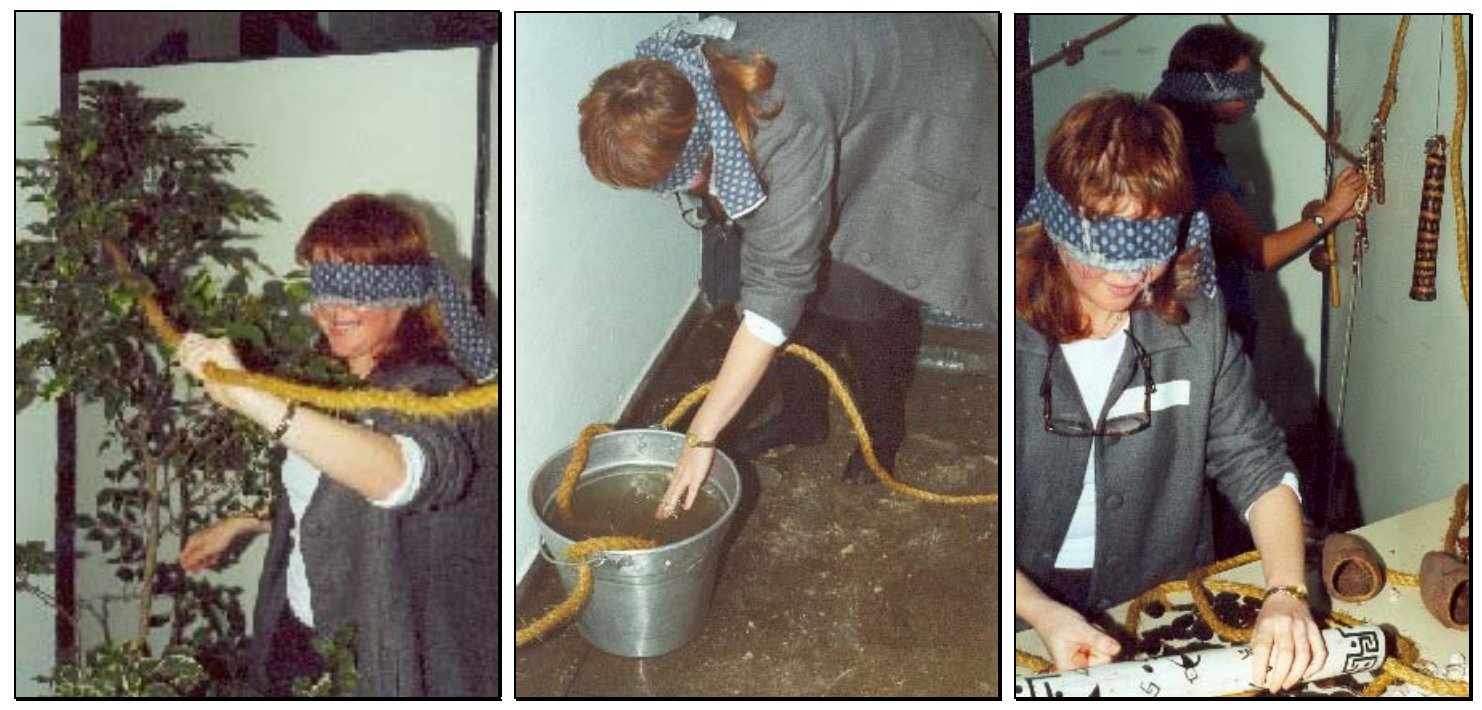

Figura 5 - Caminho dos sentidos
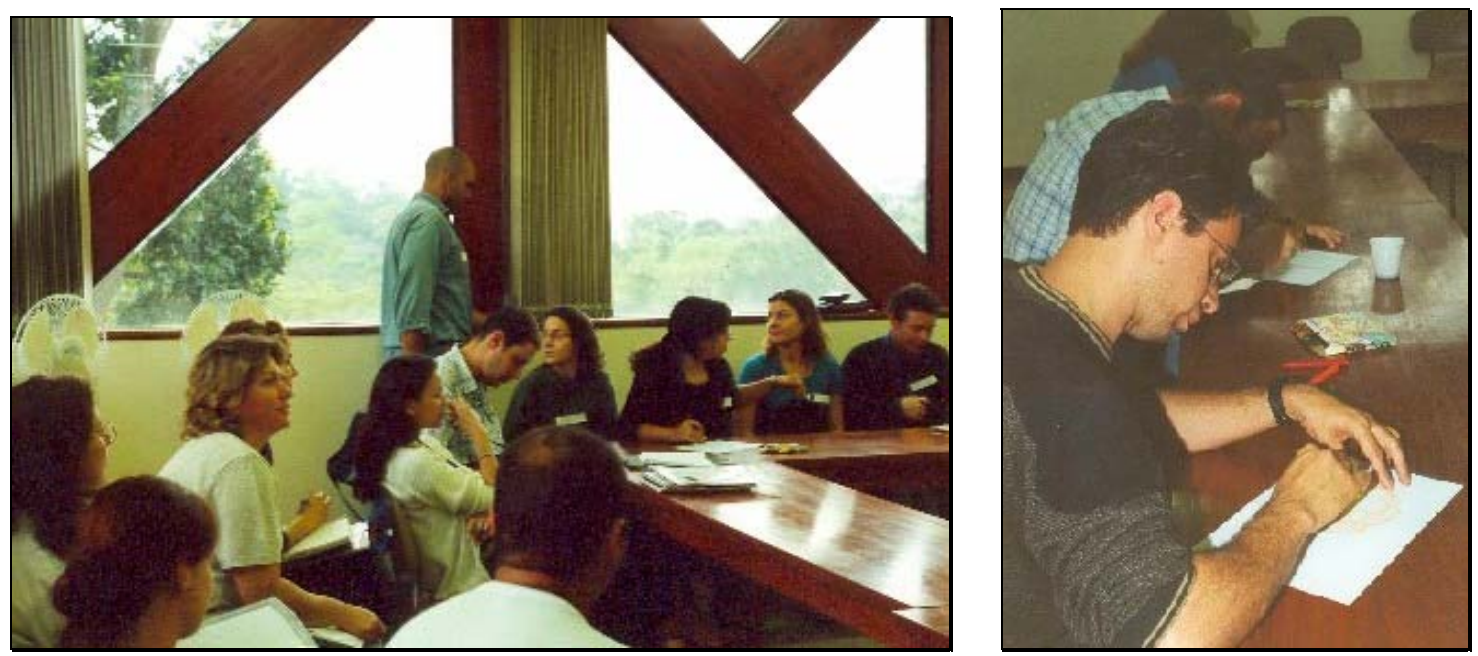

Figura 6 - Sala do mapa mental 
iv) Sala do mapa mental: no final dessa seqüência de atividades, os estudantes reuniram-se em uma sala de reuniões, com uma mesa ampla, e encontraram materiais (papel sulfite, canetas hidrocor coloridas e lápis de cera) para facilitar a construção de um mapa mental das sensações e sentimentos que afloraram no percurso do labirinto. Ali se apresentavam pelo codinome escolhido escrito na etiqueta, e socializavam as suas primeiras impressões sobre esse percurso.

Essas e outras vivências foram criadas para o primeiro encontro, com a intenção de proporcionar aos estudantes, diferentes sensações e situações, que contribuíssem para deixá-los mais abertos ao diálogo, que viessem a internalizar a proposta pedagógica de se trabalhar com outros paradigmas e linguagens e, ainda, que iniciassem o curso repensando a crise ambiental da contemporaneidade.

Para contribuir com a fundamentação teórica do encontro, organizou-se uma palestra de abertura com dois educadores ambientais: ministraram-se as disciplinas: "Técnica de Elaboração de Projetos"; "Escala, paisagens, sincronia e diacronia"; "Ferramentas no uso do ensino à distância"; "Projeto de Intervenção Educacional: Estratégias e táticas" e recomendou-se a leitura da seguinte bibliografia: Berman (1987); Calvino (1990); Ferry (1994), Garaudy (1981); Machado, J.N. (1997); Malta \& Conde (1995) e McCormick (1992).

\subsubsection{Os outros encontros concentrados}

O segundo encontro teve duração de dez dias (de 25 de janeiro a 03 de fevereiro) com 125 horas de trabalho no total, portanto bem mais longo que o primeiro.

Foram propostos para esse módulo três momentos distintos: o primeiro foi uma viagem de quatro dias à Estação Experimental de Itatinga, onde foi desenvolvida a disciplina "Re-conhecendo o meio ambiente", tratada adiante; o segundo momento foi um ciclo de minicursos organizado pelo OCA/LEPA, criado com o intuito de que os estudantes tivessem um leque de opções para aprofundar assuntos mais específicos, além das disciplinas oferecidas no cardápio do curso de especialização.

Nessa oportunidade, cada aluno fez dois cursos, sendo que de um participou normalmente como estudante e de outro como monitor. Os detalhes com as instruções para a monitoria são encontrados no Anexo D. 


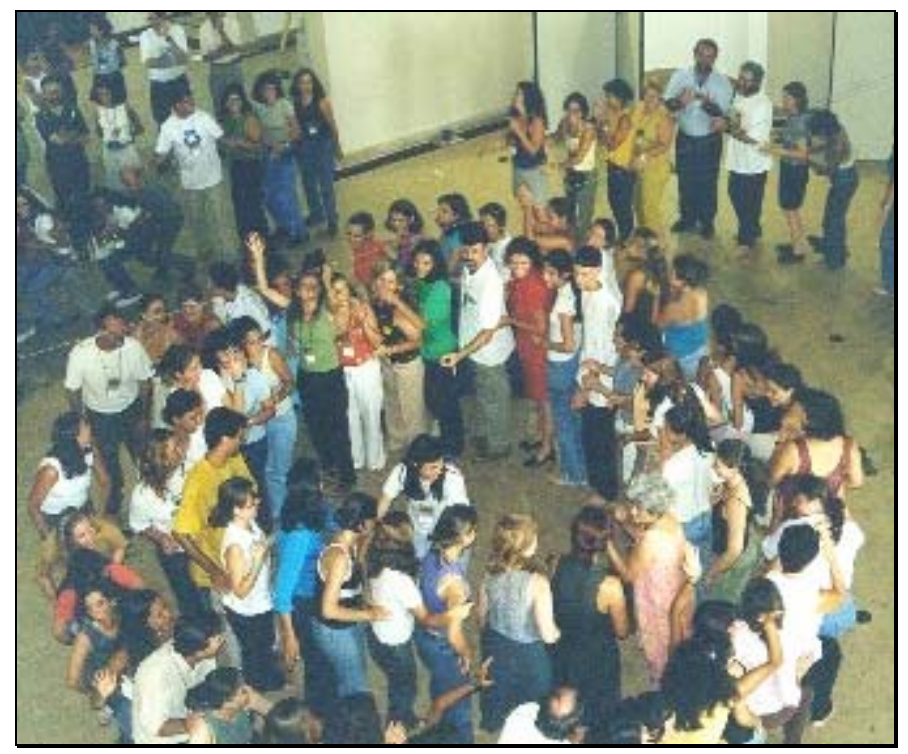

Figura 7 - Oficina "ecologia do amor"

O terceiro momento foi o encerramento no dia 03 de fevereiro, com uma avaliação sobre o curso de uma forma geral, pois já havia terminado praticamente a metade dele. Fez parte também desse encontro uma avaliação sobre o ciclo de minicursos.

O terceiro e último encontro presencial concentrado (o $10^{\circ}$ do curso) foi realizado entre 20 e 26 de julho de 2001, com um total de 60 horas de atividades de encerramento, propostas para que os estudantes se mostrassem e expressassem como educadores fazendo uso de diferentes linguagens. Os projetos de intervenção foram apresentados em forma de seminários e avaliados pela equipe de coordenação e também pelos estudantes.

$\mathrm{Na}$ mesma ocasião eles apresentaram uma proposta de mini curso em Educação Ambiental, numa perspectiva de também formar formadores. Em um dado momento, o grupo reuniu-se para definir o que era Educação Ambiental e educador ambiental para eles, produziram os "parâmetros de referência" (Anexo.E).

\subsubsection{Educação a distância}

Já no primeiro encontro foi promovida uma oficina no centro de processamento de dados do Depto. de Ciências Florestais da ESALQ, para que as informações básicas sobre a RITS e o Ciberfórum fossem socializadas. Nesse momento, contou-se com o 
apoio de uma profissional da CECAE/USP, quando foram dadas explicações básicas e distribuído um manual sobre o uso de Internet, e-mail, "spam", "netiqueta". Quatro conferências foram sugeridas para servirem de espaço virtual de socializações: "Textos", "Eventos", "Intervenção" e "Educação a distância". Pretendeu-se, desde esse primeiro encontro, estabelecer regras de funcionamento nas diferentes instâncias em que a comunicação eletrônica pudesse ocorrer: chat e conferências entre estudantes, coordenação e docentes.

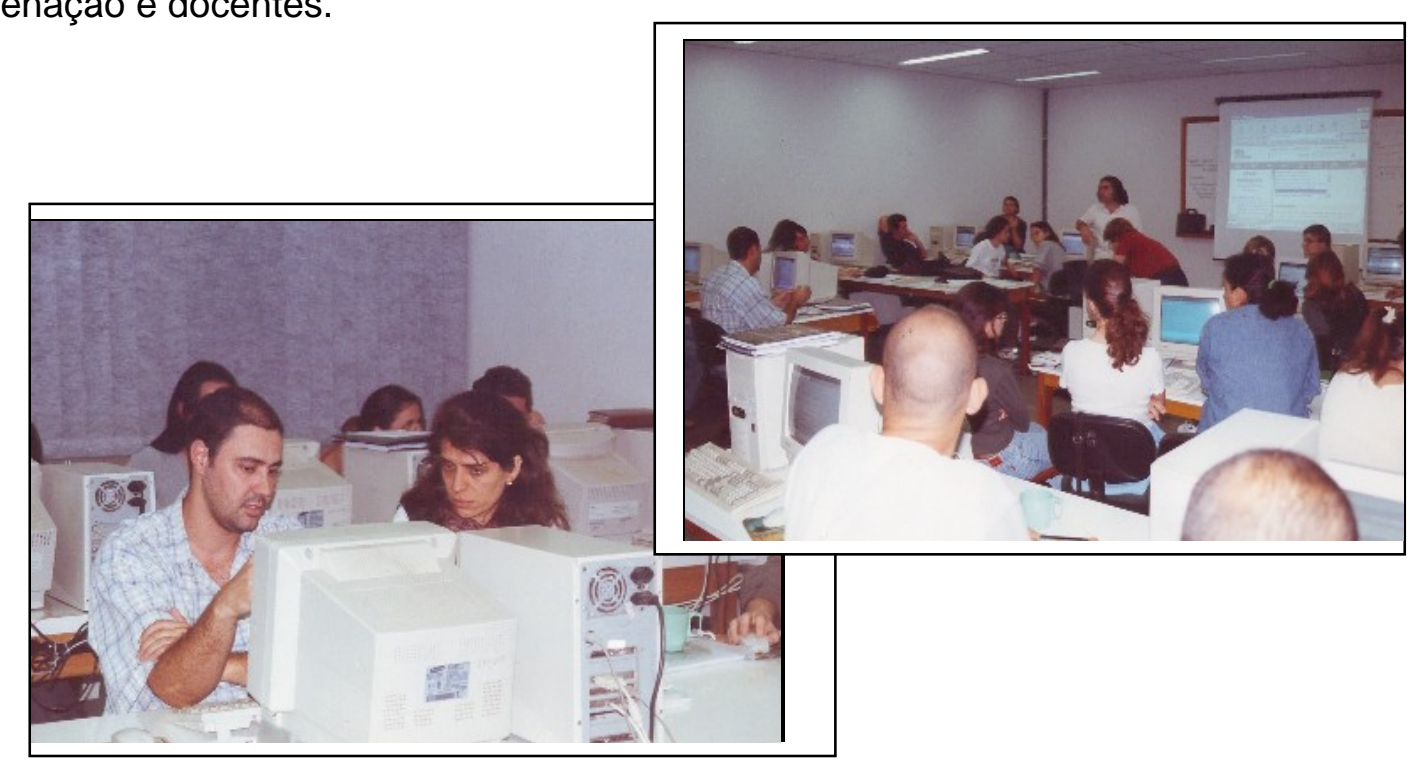

Figura 8 - Oficina de educação a distância

Apesar da dificuldade de se mensurar a qualidade de acesso à ferramenta eletrônica, pode-se afirmar que dos problemas que surgiram (avaliados pelo questionário no Anexo F), destacam-se, resumidamente:

1. A heterogeneidade da turma em relação aos conhecimentos de comunicação eletrônica: uns sabiam "muito", enquanto que, para outros, o acesso à Internet era novidade - e estes ou se desinibiram e aprenderam com rapidez, ou, em menor parte, continuaram tímidos com relação à utilização da ferramenta, ao longo do curso;

2. Problemas com a RITS - site fora do ar, lentidão, perda de documentos enviado, de arquivos e outros;

3. A falta de acesso a equipamentos de qualidade (velocidade e qualidade de conexão, provedor seguro, disponibilidade para navegar); 
4. Pouca organização dos estudantes para o tempo de estudos a distância assíncronos: abrir e ler as conferências, compreender as diferenças entre os conteúdos de cada uma, imprimir textos, responder as demandas dos docentes e disponibilizar;

5. As duas tentativas de comunicação síncrona foram consideradas aquém do esperado pela coordenação e estudantes. Foram feitos levantamentos dos problemas, exposição das dificuldades inerentes ao processo e tentativas de minimizá-las.

Uma estudante, Horologium, declara no "relatório descritivo analítico": "Infelizmente, os encontros a distância não tiveram os resultados esperados. Os motivos foram muitos: a resistência de alguns estudantes, a falta de compromisso e disciplina de outros, e problemas técnicos ligados ao RITS".

$\mathrm{Na}$ auto-avaliação, a mesma estudante reconhece-se também como aprendiz e coloca o seguinte sobre a comunicação eletrônica: "(...) deixei a desejar, mas tentei e continuo tentando, estou resistindo menos, foi um crescimento também".

Numa avaliação realizada nos primeiros 40 dias de funcionamento do Ciberfórum alguns dados foram obtidos:

- Quanto à comunicação: $42,8 \%$ dos estudantes afirmaram que ainda eram "tímidos"; $38 \%$ que eram melhores nos momentos assíncronos (que não se realizam ao mesmo tempo) e apenas 19\% afirmaram que, independentemente dos momentos, eram sempre boas.

- Quanto à facilidade de acesso: 76\% afirmaram que não tiveram problemas; 5\% não acessaram e 19\% tiveram dificuldades.

- Quanto às conferências: 52\% afirmaram que foram úteis para o aproveitamento teórico do curso, justificando que contribuíram para: troca de idéias e informações; contato com a coordenação e colegas; e enriquecimento teórico através dos textos. Os $24 \%$ que afirmaram que as conferências não foram úteis, justificaram pela falta de organização do grupo, dos assuntos e propostas.

Mesmo sabendo dos desafios que surgiriam com a utilização da Internet, a coordenação considerou-a importante como um estímulo, encarando-a também como uma forma de inclusão aos que tinham pouca familiaridade com a Internet ou comunicação eletrônica. Tendo em vista o avanço dessas ferramentas, pretendia-se 
que ajudassem a promover algumas habilidades importantes para o aproveitamento do curso como: disciplina para os estudos a distância, organização do material, participação, cumprimento de acordos e prazos com o coletivo.

\subsubsection{Aprendizagem na monitoria dos minicursos}

Em janeiro de 2001, foram oferecidos, num evento aberto após a disciplina "Reconhecendo o meio ambiente", quatro dias consecutivos de minicursos com temáticas variadas, visando ampliar a oferta de disciplinas até então ministradas. Cada minicurso foi ministrado durante dois dias, com duração de 16 horas. O estudante podia escolher e assistir a um mini-curso e participar como monitor em outro, utilizando como referencial um roteiro. Dessa forma, teria oportunidade de acompanhar os procedimentos que antecederam a preparação do curso junto ao docente, auxiliar o educador na realização em sala de aula e/ou no campo, e posteriormente, preparar e divulgar um relatório sobre os acontecimentos, eletronicamente, para que houvesse trocas entre todos os participantes.

\subsubsection{O curso em cena}

Criado o cenário e convocados os atores, promoveram-se, num processo "democrático circular"39, análises críticas sobre a crise socioambiental atual e as diversas respostas que vêm sendo dadas na contemporaneidade pelas ciências, pela política, pelas instituições educacionais e pelos movimentos sociais e religiosos, entre outros.

Essa proposta assemelha-se ao que Bavelas ${ }^{40}$, citado por Mailhiot (1991), denomina de "rede em círculo", em que coexistem estruturas de trabalho e de poder democráticas, na qual o líder democrático (no caso específico: a coordenação do curso), exerce a autoridade, tornando-se um catalizador e um coordenador para o grupo, "preocupado em abrir e manter abertas as comunicações entre todos os

\footnotetext{
${ }^{39}$ Terminologia criada por um dos estudantes para caracterizar o "espírito político" e a proposta pedagógica do curso.

40 Entre alguns dos que vieram ao Brasil no século XIX, para ver e experienciar paisagens, podemos citar Alexander von Humboldt (1769-1859), Auguste de Saint-Hilaire (1779-1853) e Carl Philipp von Martius (1794-1868).
} 
membros". Assim, "a integração dos membros pode realizar-se sobre uma base de complementariedade e não de subordinação" (Mailhiot, 1991, p.75-76).

Buscou-se diversificar a oferta de recursos didáticos de maneira a propiciar a construção de comunidades de aprendizagem: ofereceu-se um rico cardápio de disciplinas, ensino a distância, cursos e palestras de interesse do grupo; proposta de elaboração e realização de um projeto de intervenção educacional; participação no conselho do curso; confecção das atas dos encontros; avaliação dos projetos dos colegas e dos minicursos, auto-avaliação etc.

$\mathrm{Na}$ intenção de se formar formadores, buscou-se continuamente, como parte da proposta filosófica, tanto o cuidado com a linguagem quanto à elucidação dos caminhos e acontecimentos dos "bastidores" do curso. Sendo assim, mesmo os acontecimentos considerados como dificuldades eram problematizados no coletivo, como oportunidades de aprendizagem. Entre alguns dos problemas é possível citar: as mudanças ocorridas na equipe de coordenação, as dificuldades da comunicação eletrônica, bem como da compreensão da proposta do ensino a distância, mas, principalmente, a compreensão do plano do curso.

Tendo em vista as oportunidades de aprendizagem oferecidas no curso de especialização, que teve como princípio contribuir com a construção de sociedades sustentáveis, numa perspectiva de desenvolver um ensino-aprendizagem de forma dialógica, visando estimular a participação, a emancipação e a autonomia de uma comunidade de aprendizagem, considerou-se relevante seu ineditismo e ousadia nas propostas inovadoras e democráticas para esses fins.

No "relatório descritivo-analítico" de diversos estudantes, ficam explicitadas algumas dessas contribuições. Horologium, na sua auto-avaliação, declara o seguinte:

"A capacidade de perceber e valorizar a diversidade, para 0 crescimento do eu e do outro, considero como ponto-chave para formar-me como educadora ambiental, e permitir a formação dos outros também. Acredito que faltava no meu trabalho favorecer mais a participação dos alunos, não direcionar; favorecer a autonomia (...)". 
Em outro exemplo, as trocas de pareceres sobre os projetos de intervenção entre os colegas suscitou reflexões, dúvidas, aprendizagens como as declaradas por Horologium:

"Durante a trajetória do curso, coisas muito interessantes foram acontecendo (...). os textos, os filmes, as tarefas, foram sempre motivo de troca, de conhecimento e crescimento. Aí uma tarefa que gerou um pouco de insegurança foi sobre nosso "olhar" do educador, avaliando um outro aluno do curso (...) as trocas de experiências foram esclarecedoras e percebemos que todas tinham dificuldades".

Essa proposta de construção do conhecimento era difícil de ser compreendida. Muitas vezes, eles resistiam ou tiveram dificuldades de compreender, como exemplifica a fala de Draco, quando se refere ao sexto encontro:

"Nesta ocasião pudemos discutir um pouco mais sobre a importância da evolução do nosso grupo no sentido da construção de uma comunidade de aprendizagem onde todos aprendem, ensinam, trocam, têm responsabilidades e crescem juntos. Foi exatamente a partir dessa compreensão que percebi estar crescendo individualmente e profissionalmente. Entendo que todos os encontros apresentaram muitas oportunidades de aprendizagem, não só em relação às atividades, leituras e pessoas excepcionais que foram convidadas, mas também, em relação às situações de conflito que surgiram no percurso, principalmente àquelas referentes ao processo de construção da nossa comunidade de aprendizagem (relações intergrupais, relações grupo-coordenação, desistências de alguns companheiros etc)".

No último encontro, uma atividade proposta foi a construção da "árvore do tempo", sob coordenação da pesquisadora que, na ocasião se encontrava afastada da coordenação do curso. Sobre um tecido de juta de $3 \times 3 \mathrm{~m}$ foi desenhada uma árvore e os encontros eram os frutos. Algumas lembranças do período foram pintadas pelos 
estudantes que desenharam e escreveram com liberdade de expressão. Dessa vivência, Horologium coloca o seguinte:

"Durante a construção da árvore do tempo, ainda senti dúvidas sobre o grupo: será que realmente somos um grupo de aprendizagem? Só depois percebi que cada um com a poética, outros com a escrita, com a representação, com a forma (...) mas todos contribuíram".

Num balanço final quantitativo, pode-se afirmar que pelo menos 10, dos 24 estudantes egressos, tiveram iniciativas em organizar e ministrar - individual e coletivamente - cursos, palestras e oficinas para diferentes públicos como educadores ambientais.

Dois meses após o final do curso, os egressos organizaram o " $11^{\circ}$ encontro" em Piracicaba. Os mais engajados nessas propostas coletivas promoveram, ao longo desses dois anos após o término do curso, aproximadamente 10 reuniões e encontros para discutirem sobre a formação de um grupo de educadores ambientais, tendo como objetivo principal a elaboração de minicursos e oficinas de Educação Ambiental para públicos diversos. Até o momento ainda mantêm contato presencial ou virtual para troca de experiências e confraternização.

Nessa perspectiva, Shultz" ${ }^{41}$, comentado por Mailhiot (1991), coloca que "há uma equação entre a integração de um grupo, a solidariedade interpessoal de seus membros e a satisfação em grupo e pelo grupo das necessidades de inclusão, de controle e de afeição de seus membros" (Mailhiot 1991, p.69).

Apesar dessa sinergia envolvendo parte do grupo, pode-se dizer que cerca de seis deles, que também durante o curso pareciam "distantes" do coletivo, não participaram destas iniciativas, porém formando entre eles, subgrupos de trabalho para desenvolver outras atividades.

Vários egressos mantêm contato ainda hoje com o laboratório (OCA) e com os projetos nele desenvolvidos e/ou por ele apoiados. Outro ponto importante a ser destacado é o fato de que quatro egressos entraram em programas de mestrado da

${ }^{41}$ SCHUTZ, W.C. Firo, a three dimensional theory of interpersonal behavior. New York, Holt, Rinehart \& Co. 
USP (Cetus no PPGI/ESALQ e Cassiopéia no PROCAM/São Paulo); na UNICAMP (Draco); e, na UNIMEP (Crux).

\subsection{Ensinando a estudar o ambiente}

\subsection{1"Re-conhecendo o meio ambiente" - uma restrospectiva}

Programou-se uma disciplina sobre estudo do meio, ministrada em Itatinga/SP, município distante de Piracicaba cerca de $150 \mathrm{~km}$. Seis meses antes da viagem propriamente dita, iniciou-se uma série de atividades de planejamento, tanto da disciplina em si (conteúdos, materiais e equipamentos necessários), como também, da logística que seria necessária: deslocamento, seguro viagem, alojamento, infraestrutura disponível, etc ${ }^{42}$.

Como seria realizada 5 meses após o início do curso, haveria tempo para o envolvimento dos estudantes com a proposta. A expectativa em relação ao evento, entre coordenação e discentes, era grande. Algumas vivências, como por exemplo, pequenas caminhadas por uma mata ciliar da ESALQ e a experiência de "encontrar a sua árvore" foram realizadas pelo prof. Marcos Sorrentino, durante os encontros que antecederam a disciplina, para ir despertando nos estudantes atividades que estimulassem a atenção, a observação e a percepção.

Escolheu-se a Estação Experimental de Itatinga, mais conhecida como Horto Florestal da ESALQ/USP, em função: i) da proximidade de Piracicaba; ii) dos recursos materiais e naturais disponíveis; e iii) do baixo custo com despesas ${ }^{43}$ de transporte e hospedagem. A viagem ocorreu no mês de janeiro de 2001 que, por ser de férias escolares, contribuía para que todos pudessem participar da viagem.

Sem dúvida, esse período de planejamento demandou muitas horas de trabalho, organização e reflexão. Uma pergunta pairava no ar: como despertar e manter o interesse dos estudantes nos quatro dias de atividades? Essa preocupação com a programação devia-se a alguns fatores:

* A maioria deles já estava bastante habituada a caminhar em trilhas ou fazer turismo de aventura. Portanto, era necessário oferecer algo novo, interessante;

\footnotetext{
${ }^{42}$ No período que antecedeu a viagem e durante a disciplina foi valiosa a contribuição de duas profissionais: Isabel Barros, engenheira florestal e Isabel Cristina da Silva, engenheira agrônoma e educadora ambiental da estação experimental.

${ }^{43}$ Todas as despesas com transporte, alimentação, hospedagem, etc, foram pagas pelo curso.
} 
* alguns deles tinham pouca ou nenhuma experiência de campo, portanto, era preciso incluí-los para que não se sentissem "apartados" e todos pudessem se ajudar e socializar as experiências;

* havia a vantagem de que apenas uma estudante conhecia o horto. Podia-se, então, contar com o elemento surpresa em relação aos atrativos cênicos "modestos", se comparados aos de outras paisagens brasileiras freqüentadas e citadas pelos estudantes, como as da Ilha do Cardoso/SP, do Parque Nacional de Itatiaia/MG, Conceição da Barra/ES, entre outros locais.

Diante dessas perspectivas, prentendia-se ensinar a valorizar os recursos disponíveis, não se detendo ao ideal, e sim ao real. Era importante também dar continuidade à proposta do curso de contribuir para a construção de comunidades de aprendizagem, portanto, as atividades foram planejadas e realizadas numa "espiral ascendente", de maneira que o grau de dificuldade e desafio que tivessem que enfrentar fosse cada vez maior, visando fortalecer as relações de confiança individual e do grupo.

"Seria lícito esperar que o planejamento de escolas e salas de aula se baseasse numa análise do modo ótimo de executar tarefas de crescente dificuldade, isto é, tornando-se cada vez mais orientado para a espécie de resolução de problemas de cooperação grupal que caracteriza a vida real contemporânea em organizações de trabalho" (Lee, 1977,p.97.)

Elaborou-se um guia (Anexo G) para oferecer aos estudantes um exemplo de ferramenta considerada importante para as atividades de campo, isto é, não só como base para anotações de dados e observações, mas também como uma referência sobre as atividades propostas.

Com esse mosaico de possibilidades, programou-se a disciplina em dois grandes blocos de atividades: um "conceitual" (com vivências, aula prática, teórica e palestra), oferecido para contemplar os conteúdos propostos, e outro "social", em que os estudantes teriam oportunidade de lazer e interação em "espaços diferenciados".

Basicamente foram quatro atividades conceituais: "aprendizado na natureza", "estudo do meio", "jogos cooperativos" e, "educação ao ar livre" (ministrada por Isabel Barros). No último dia fez-se uma atividade solo, comum em atividades de outdoor education. 
A seguir, será tratado brevemente o desenvolvimento das atividades, que contou, no campo, com o apoio de uma pequena e eficiente equipe.

Ainda no campus da ESALQ, fez-se uma reunião no gramado, em frente à garagem, para os "combinados", sendo que a idéia central foi a importância da participação e do despojamento de todos para a realização das atividades propostas.

Ao chegarem ao horto, numa tarde de calor, foram deixados numa cachoeira e receberam a instrução de, após o banho, seguirem por uma trilha até encontrarem "algo". Para isso, precisavam se organizar para abrir e fechar a trilha, ajudar os que tinham mais dificuldades, etc. Apenas uma estudante conhecia o percurso, mas o grupo não tinha conhecimento do fato.

No fim da trilha havia uma fogueira ao redor da qual os membros da equipe estavam sentados, tocando instrumentos musicais artesanais. Eles foram se chegando, formando um círculo em silêncio e escolhendo um instrumento para tocar. Ninguém deu instruções ou explicações, eles foram apenas "pressentido" a intenção e entrando na proposta: "afagar", com o calor do fogo e da música, a apreensão em trilhar, sem guia, na mata, por um "caminho desconhecido". Eles haviam conseguido!

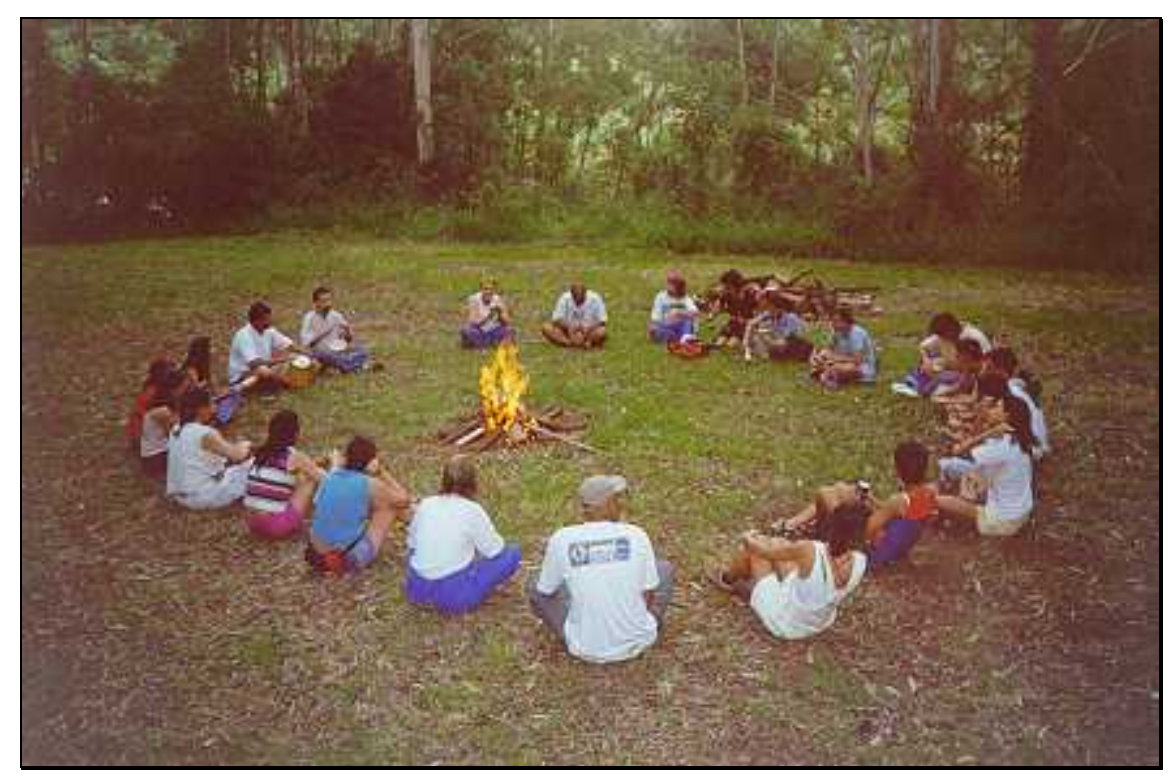

Figura 9 - Chegando da cachoeira

Ao final do dia, a distribuição nos alojamentos foi feita mostrando-se um croqui e deixando que escolhessem seus pares, elegessem um coordenador e partissem para 
encontrar o local escolhido. A função do coordenador era de reportar-se à professora para resolver problemas corriqueiros da casa.

Nessa noite, como nas outras, fez-se uma avaliação do dia. Ao comentarem sobre os acontecimentos na trilha, alguns se mostraram indignados com a trilha, com os riscos que poderiam estar correndo por estarem sem lanternas, caso escurecesse, etc. Explicou-se, então, que havia entre eles uma pessoa que conhecia o caminho e saberia nos encontrar em caso de emergência. Reconheceram que a trilha era de baixo grau de dificuldade e que o fato de lidar com o desconhecido causou um certo temor. Depois das explicações, todos se sentiram mais calmos e confiantes, ficando claro que conhecíamos os percursos e sabíamos o que estávamos fazendo.

No segundo dia, a primeira vivência foi baseada nas experiências de Cornell (1995; 1997), de aprendizado na natureza, quando foi desenvolvida a seqüência que o autor propõe:

i) despertar o entusiasmo ("corujas e corvos"). As regras dessa atividade são como as de um jogo de "pega-pega": são feitas afirmações para esses dois grupos, que estão frente a frente, separados por uma linha divisória. No caso de serem verdadeiras, as corujas correm em direção aos corvos, que se chegarem ao "pique" estão salvos. Reinicia-se com outra afirmação.

ii) Depois, para concentrar a atenção ("trilha de surpresas") os estudantes são colocados em fila indiana à margem de uma mata, onde estão escondidos muitos objetos industrializados, alguns bem à vista e outros não. Eles devem, em silêncio, observar e mentalmente contar cada um deles. Ao final da pequena trilha, devem dizer à professora o total de objetos encontrados. Recomenda-se retornar ao início e recontar, procurando por todos os itens.

iii) "Abraçando a árvore" e "máquina fotográfica" são atividades que devem ser realizadas em duplas, indicadas por Cornell para "dirigir a experiência". Um deles venda os olhos e é dirigido pelo outro para abraçar uma árvore aleatória, no arboreto de eucaliptos do horto. Ele deve depois ser afastado da árvore que abraçou e tentar encontrá-la com os olhos desvendados. Na "máquina fotográfica", o colega sem vendas escolhe uma paisagem, direciona a posição da cabeça do colega vendado que, ao desvendar os olhos, fixa a imagem escolhida pelo outro.

iv) Uma etapa muito importante é a de compartilhar a inspiração. Para isso, fizemos uma roda ao final de cada atividade e exploramos ao máximo os sentidos 
utilizados, as sensações, lembranças e atenção que foram bastante exigidas nestas vivências.

Uma estudante, Crux, relata: "A partir do momento que fizemos o arboreto, voltei a ser criança, voltei a prestar atenção em todos os locais. Cada "partezinha" me lembrava, trazia recordações, confirmando o que vim buscar".

À tarde, foram divididos em grupos e tinham como tarefa propor um estudo do meio a partir de alguns locais estratégicos do horto: viveiro de mudas, estufa de produção de shitake, centro de visitantes, etc. O importante era observar um determinado local, associá-lo a algum conteúdo curricular e apresentar para os colegas, após a confecção de um cartaz. Essa atividade causou muita polêmica, como será apresentado na avaliação da disciplina, porém, desencadeou uma inquietação que culminou numa discussão acerca do curso: seus propósitos, seus princípios, etc.

A seguir, assistiram a uma palestra sobre as atividades de pesquisa desenvolvidas no horto, ministrada pelo engenheiro florestal responsável pela estação experimental. À noite, todos foram para a cidade de Itatinga, jantar numa pizzaria.

$\mathrm{Na}$ manhã seguinte prepararam o café da manhã e realizaram os jogos cooperativos, contribuição do educador Brotto (1999). A "dança das cadeiras cooperativa" foi um ponto importante, talvez pelo fato de que nessa proposta ninguém sai da brincadeira, as cadeiras é que saem e os participantes vão sentando uns em cima dos outros, como for possível, até o limite máximo do grupo. É um momento que proporciona grande descontração, promove a aproximação e um maior contato físico entre eles, preparando-os para as atividades que viriam a seguir.
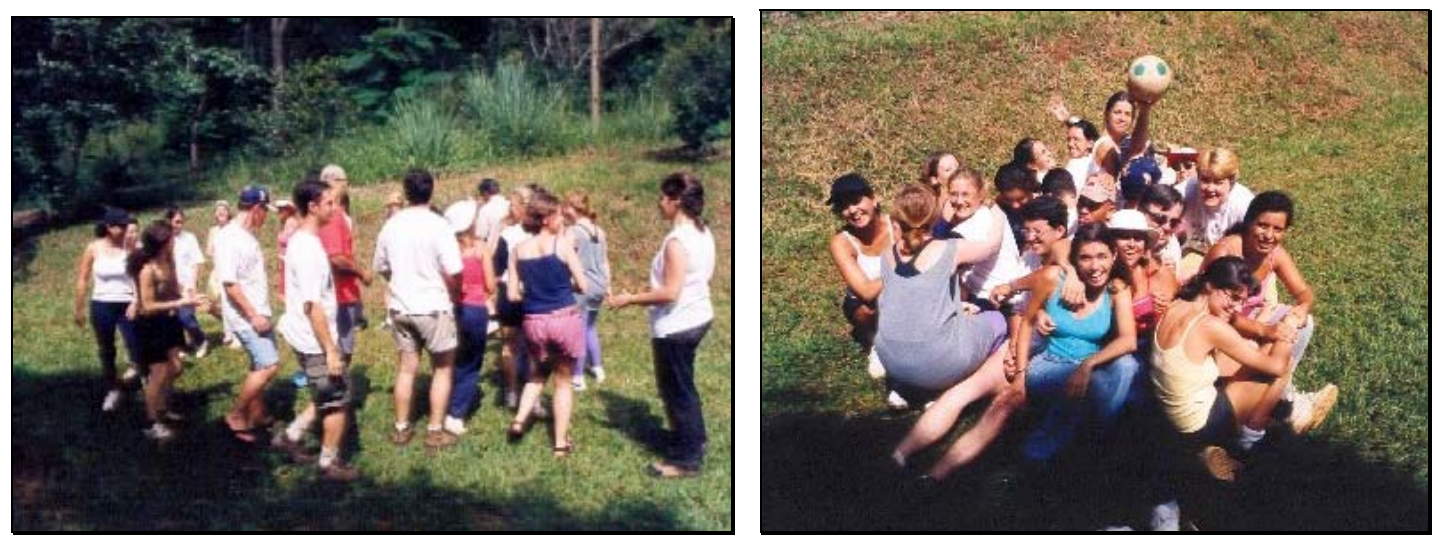

Figura 10 - Jogos cooperativos 
Em uma delas, no "futpar", formaram pares e só podiam jogar futebol abraçados, como se fossem um. Essa dinâmica foi a última da manhã antes do almoço, fazia muito calor e eles estavam exaustos. Os jogos cooperativos terminaram com a leitura de um pequeno texto sobre a cooperação que existe na formação do vôo dos gansos selvagens.

A tarde foi a vez da educação ao ar livre, mais diretamente a vertente "ropes course", bastante conhecida nos Estados Unidos e divulgada no Brasil pela Outward Bound Brasil. Foi proposta uma seqüência de atividades quebra gelo, de aquecimento, sobre confiança, resolução de problemas e responsabilidade.

Para quebrar o gelo, foram convidados a se posicionarem aleatoriamente sobre um tronco de eucalipto caído na mata, sem espaço entre eles. Foi pedido que se organizassem por ordem alfabética do nome e, depois, por data de nascimento (mês e ano). Assim teriam que se falar, se tocar e ajudar a transpor os colegas para ficarem na ordem solicitada.

A "teia de aranha" foi a última atividade coletiva e a de maior grau de dificuldade, pois, numa versão adaptada, cada um dos estudantes teria que passar por um dos vãos da "teia de aranha", formada por um fio de barbante tecido entre duas árvores. As regras eram bem claras e aparentemente simples: cada vão só poderia ser utilizado por duas pessoas, depois seria "inutilizado"; não poderiam esbarrar no barbante; todos teriam que passar para o outro lado.

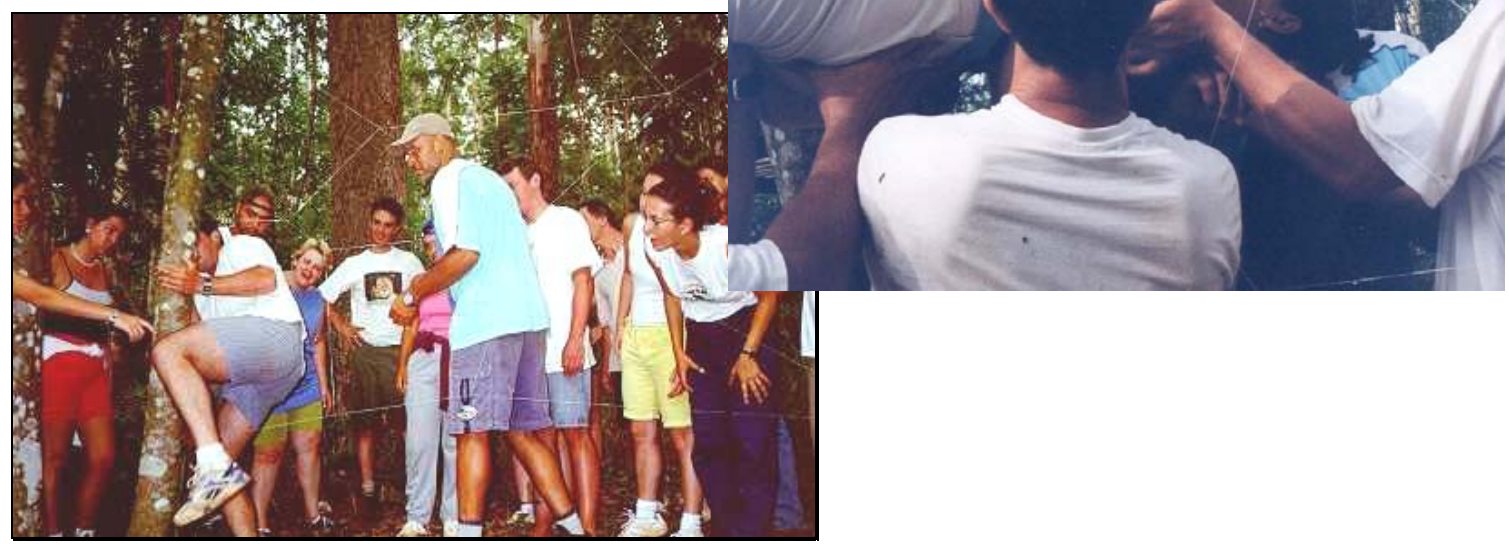

Figura 11- A passagem pela teia de aranha 
Portanto, a fim de realizarem a atividade com sucesso, era necessário o planejamento antecipado para avaliarem as dimensões tanto dos vãos quanto dos colegas, pois alguns teriam que ser carregados para passarem pelo alto.

A última noite foi celebrada com uma festa surpresa. Foram convidados músicos locais para tocarem "música de raiz". Todos dançaram muito e o momento da quadrilha (que não foi planejado) consagrou a coesão do grupo e fez emergir recordações da infância de muitos.

$\mathrm{Na}$ última manhã, fez-se o fechamento sobre estudos do meio e depois foi proposta a atividade solo, quando o estudante foi convidado a ficar sozinho e, na quietude, fazer um mergulho interior, resgatar o que foi visto, as sensações,as impressões; pensar no passado e projetar um futuro. Nesse momento, escreveram uma carta e endereçaram para si mesmos. A ministrante postou-as depois de 5 meses.

Fechou-se a disciplina com um roteiro (Anexo $\mathrm{H}$ ) para avaliar cada atividade social e conceitual - e com uma rodada final para compartilharem as impressões através da pergunta: "Nesses quatro dias de viagem, o que houve de contribuição para sua atuação profissional e sua trajetória pessoal?"44. Nesse momento, também foi proposta a atividade a distância: deveriam formular um estudo do meio utilizando o entorno em que estavam inseridos, como recurso pedagógico.

\subsection{2"Re-conhecendo o meio ambiente" - as decorrências}

Após os quatro dias de atividades no campo, quando se apresentou teoria e prática de diferentes técnicas que podem ser utilizadas com finalidade educativa, houve várias manifestações positivas dos estudantes, indicando que, além dos objetivos terem sido alcançados, algo mais ocorrera.

Os estudantes citaram, insistente e aleatoriamente, as atividades realizadas em Itatinga nos cinco encontros presenciais após essa viagem, e acredita-se que um dos motivos seja pelo fato de ter-se adotado a prática - que os envolveu e coresponsabilizou - de, ao final de cada atividade, fazer um fechamento, sem "quebrar o clima" sobre as percepções individuais e do coletivo, as variações e limitações de cada vivência, etc. E ainda, ao final do dia, desvelavam-se todos os detalhes precedentes dos trabalhos de campo: desde a etapa preparatória da viagem em si, os materiais

\footnotetext{
${ }^{44}$ A pergunta foi formulada para ampliar o leque de respostas, não que haja uma cisão entre "profissional" e "pessoal".
} 
necessários, a importância da seqüência das atividades, até o planejamento geral junto aos técnicos da estação experimental.

Nos trabalhos e apresentações finais dos alunos (o projeto de intervenção educacional, relatório analítico-descritivo e um minicurso), ficou explicitado o interesse deles em incorporar estudos do meio na sua prática profissional. As contribuições objetivas e subjetivas - advindas dos trabalhos em Itatinga foram inúmeras, mas, de forma geral, as mais citadas foram: a possibilidade de incorporação dessas atividades na atividade profissional; o fortalecimento e estreitamento das relações profissionais e pessoais do grupo; o aumento da autoconfiança, da autonomia e da responsabilidade individual e coletiva para realizar os trabalhos propostos no curso e além dele.

Com base nessas informações, a pesquisa, então de mestrado, ampliou-se através de uma proposta de doutorado direto, pois percebeu-se ser relevante relatar e aprofundar a análise sobre a importância das vivências no curso e na disciplina, para esse grupo; agregando dados provenientes das observações e acompanhamentos das atividades profissionais - correlatas à utilização de estudos do meio - dos egressos. Na perspectiva de compreender qual havia sido o diferencial dessa disciplina, buscou-se no conceito de "pertencimento", presente no ideário ambientalista, algumas respostas para expandir o entendimento sobre a complexidade das questões ambientais e da formação de pessoas.

\subsection{O trabalho de campo - coleta de dados}

"A finalidade real da pesquisa qualitativa não é contar opiniões ou pessoas, mas ao contrário, explorar o espectro de opiniões, as diferentes representações sobre o assunto em questão" (Bauer \& Gaskell, 2003, p.68).

Essa pesquisa trata de um estudo de caso inserido num contexto histórico, a partir de um grupo social determinado - estudantes ingressantes num curso e depois, já egressos - e com características próprias. Ela foi circunscrita com dados coletados, durante e após uma intervenção educacional complexa já descrita - um curso piloto e uma disciplina, utilizando-se os fundamentos e referenciais teóricos próprios da 
pesquisa social ${ }^{45}$. Os documentos foram tratados, principalmente, através de uma abordagem qualitativa, visando contribuir para confirmação da hipótese ${ }^{46}$.

Nesse sentido, buscou-se captar, através de técnicas distintas ${ }^{47}$, as contribuições para os estudantes, nesse conjunto de atividades que ocorreram no curso de especialização "Formação de educadores ambientais para sociedades sustentáveis", realizado na ESALQ/USP/Piracicaba (SP) entre setembro de 2000 e julho de 2001.

O detalhamento das técnicas que envolveram a coleta de dados, em diferentes momentos, será descrito a seguir. O trabalho de campo durou aproximadamente três anos e meio, entre setembro de 2000 e fevereiro de 2004, sendo que o número de participantes em cada etapa variou ao longo do período, em função das desistências tanto do curso quanto da participação na própria pesquisa.

Para facilitar a visualização das etapas da pesquisa de campo, foi construído um mapa com os materiais coletados, apresentado na Figura 12, nos diferentes momentos da pesquisa e as respectivas técnicas. Através dele, pretende-se destacar ainda, o volume de documentos coletados e os temas prioritários.

Esse conjunto de matérias referem-se ao que foi denominado de dados primários.

\footnotetext{
${ }^{45}$ Lüdke (2001, p.12) aponta cinco características básicas da pesquisa qualitativa descritas por Bogdan \& Biklen (1982): "a pesquisa qualitativa tem o ambiente natural como sua fonte direta de dados e o pesquisador como seu principal instrumento", "os dados coletados são predominantemente descritivos", a preocupação com o processo é muito maior do que com o produto", "o 'significado' que as pessoas dão às coisas e à sua vida são focos de atenção especial pelo pesquisador", "a análise de dados tende a seguir um processo indutivo".

${ }^{46}$ Os estudos do meio podem contribuir para a formação de educadores ambientais capazes de utilizá-los como caminho para se atingir objetivos educacionais e do ambientalismo relacionados ao conceito de pertencimento.

${ }^{47}$ Questionário, entrevista semi-estruturada, visita in loco com observação-participante.
} 

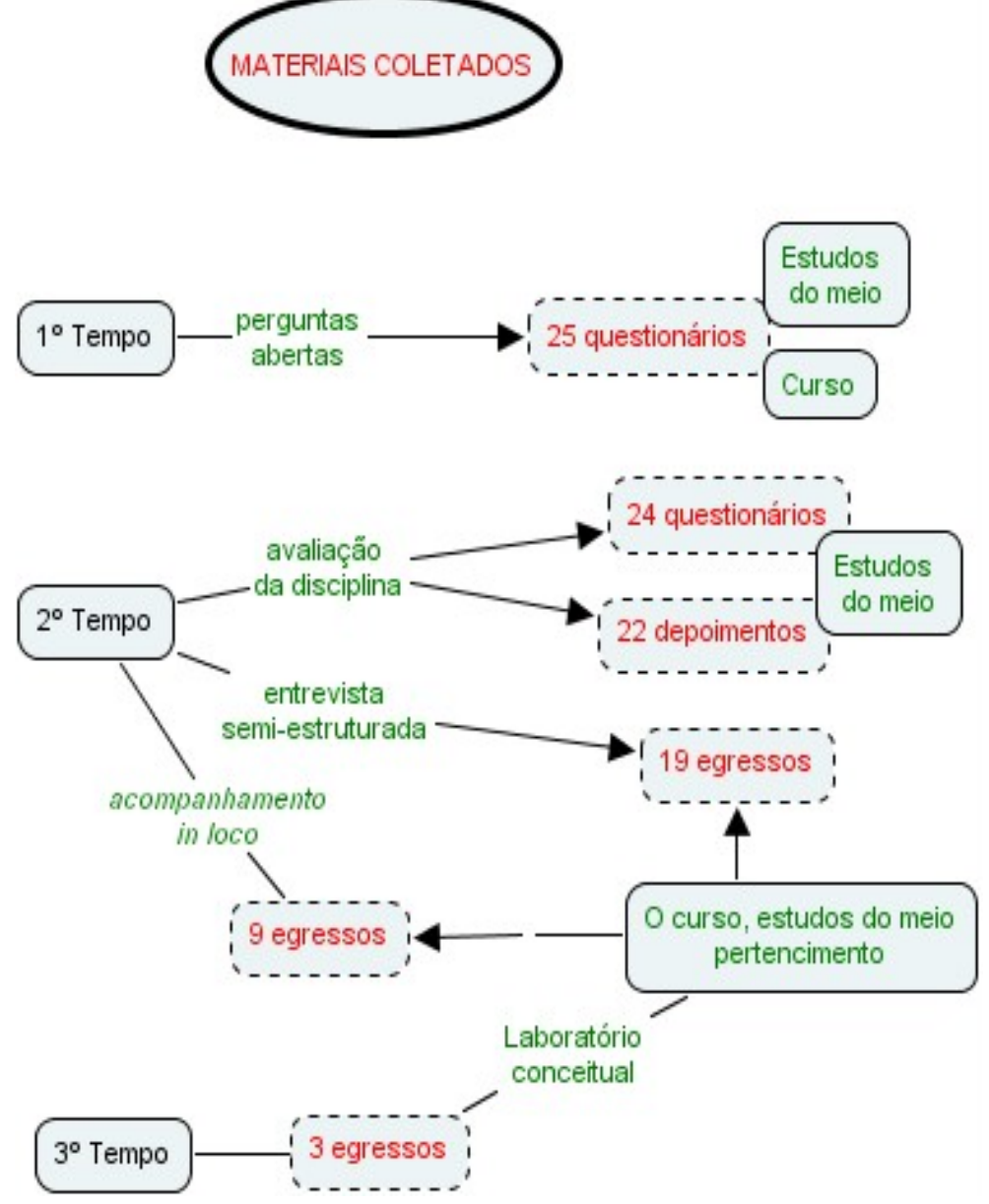

Figura 12 - Mapa dos materiais

\subsubsection{O trabalho de campo no $1^{\circ}$ tempo}

No 1ํㅡㄹ tempo, a técnica escolhida para coleta de dados foi o questionário com perguntas abertas, como primeira intervenção do primeiro dia do curso de especialização, de maneira que os ingressantes não tiveram a interferência deste. Tal momento foi denominado de "ponto zero" e todos os presentes àquele ocasião receberam e responderam as questões. Cabe destacar que oito questionários foram entregues em dias posteriores, por motivos diversos, e, portanto, foram desconsiderados.

O "ponto zero" foi realizado no auditório do Dept ${ }^{\circ}$. de Ciências Florestais da ESALQ/USP, onde cada participante, após passar pela recepção, recebeu uma folha com as questões, que deveriam ser respondidas individualmente. 
No questionário, destacaram-se dois temas de interesse: as expectativas em relação ao curso e o conhecimento a respeito de estudos do meio. Após esse evento, o momento do "ponto zero" foi relembrado e citado pelos estudantes por várias vezes durante o curso. Nessas oportunidades, alegaram que a estratégia utilizada causou desconforto, um impacto negativo por ter sido considerada, de caráter avaliativo, logo no início de um curso.

\subsubsection{O trabalho de campo no $2^{\circ}$ tempo}

As coletas descritas a seguir, realizadas no $2^{\circ}$ tempo, foram subdividas em duas fases. A primeira - "Itatinga I" e "Itatinga II" e, depois, a segunda, que ocorreu após o término do curso, com os egressos que aceitaram participar da: "entrevista semi-estruturada" (Anexo I) e/ou do "acompanhamento in loco".

A primeira fase, com características da pesquisa-ação, tinha como objetivos avaliar e finalizar a disciplina "Re-conhecendo o meio ambiente", realizada no Horto da ESALQ em Itatinga/SP, na metade do curso de especialização, em janeiro de 2001. Utilizou-se um questionário com perguntas semi-abertas e, depois, numa "rodada final" que foi gravada em fita $\mathrm{K} 7$ (com $1 \mathrm{~h}$ de gravação), responderam a seguinte pergunta aberta: "Quais foram as contribuições pessoais e profissionais da disciplina?".

Para a realização da entrevista semi-estruturada, já na segunda fase, inicialmente fez-se um contato via e-mail (Anexo J), a partir de uma lista de endereços de que a coordenação do curso dispunha. Durante toda essa etapa, teve-se o cuidado de usar a mesma linguagem e tratamento com os egressos, a fim de se minimizar 'controvérsias'.

Durante o $2^{\circ}$ semestre de 2001, alguns deles estavam cursando disciplinas ou fazendo outras atividades no campus da ESALQ/USP, então, aproveitou-se dessas oportunidades para a realização de oito entrevistas. Depois disso, buscou-se, por inúmeras vezes, comunicação com os outros 16 egressos por telefone e via e-mail, a fim de se detalhar a necessidade e o propósito do encontro e sua importância para a pesquisa. Nesse período, a pesquisadora empenhou-se firmemente em explicitar para os egressos o caráter da coleta de dados, que não tinha um fim avaliativo do sujeito em si, mas sim de compreender o estado da arte de alguns conceitos do ambientalismo e as contribuições do curso num âmbito mais amplo. 
Enfim, depois de muitos telefonemas, explicações e trocas de e-mail, durante o ano de 2002, outros 11 egressos dispuseram-se a agendar e realizar um encontro para a entrevista, a partir do roteiro semi-estruturado. O procedimento era: primeiro fazer os cumprimentos gerais e dar explicações sobre a entrevista gravada e atualização dos dados sobre as atividades do egresso; depois realizar a entrevista em si e finalizar falando sobre os próximos passos da pesquisa e do pesquisado.

Todas as entrevistas semi-estruturadas foram gravadas em fita $\mathrm{K} 7$, tiveram duração entre 20 e 40 minutos e depois foram transcritas. Entre os cinco egressos que não participaram dessa etapa, uma estava impossibilitada de responder a entrevista, alegando motivo de doença e os outros quatro, os mesmos já mencionados anteriormente como "distantes" do coletivo, não deram nenhum retorno às comunicações empreendidas. Visando abranger o maior número possível de egressos entrevistados, chegou-se a pensar no envio de telegrama e/ou carta registrada. Tal possibilidade foi descartada, ao ponderar-se que o grupo poderia ficar desconfortável tanto na entrevista quanto no futuro, no acompanhamento in loco, o que era indesejável para a pesquisa e pela pesquisadora.

Grande foi a dificuldade e a demora em realizar as 19 entrevistas, pelo fato de que a maioria deles estava morando distante de Piracicaba, sendo necessário conciliar o deslocamento da pesquisadora e/ou do entrevistado. Esses encontros, que ocorreram entre setembro de 2001 e setembro de 2002, representaram um momento importante na perspectiva da continuidade e conseqüente evolução da pesquisa, pela oportunidade e necessidade de se restabelecer um diálogo com os egressos, principalmente tendo-se em vista que, em caso de haver muitas recusas, o trabalho de campo não se realizaria, ficando a diversidade de coleta de dados aquém da expectativa.

Durante a entrevista, na medida em que se prosseguia a conversa com o sujeito, incorporavam-se perguntas encadeadas, no sentido de obter algum esclarecimento ou aprofundamento dos temas. Ao final de cada encontro, a pesquisadora explicitava a sua intenção de continuar com o trabalho de campo, e realizar, futuramente, o acompanhamento in loco. Todos os 19 entrevistados concordaram facilmente em continuar contribuindo com a pesquisa, mostrando interesse pelos resultados. 
O acompanhamento in loco foi realizado após diversos contatos telefônicos e também via e-mail, em que se comunicava ao egresso que participou da entrevista semi-estruturada, a firme intenção de acompanhar uma atividade profissional que estivesse desenvolvendo. A partir do momento que um egresso confirmava a realização de um estudo do meio ou de outra atividade como educador ambiental, iniciava-se uma série de procedimentos para a realização de cada acompanhamento, distintamente.

A pesquisadora dispunha de carro particular, o que facilitou o deslocamento, pois, na maioria dos casos, os acompanhamentos ocorreram em locais de difícil acesso, tendo como ponto referencial a partir da cidade de Piracicaba/SP, além da facilidade para se transportar alguns equipamentos. Para isso o apoio da FAPESP foi fundamental. Como exemplo de locais mais distantes, pode-se citar Cananéia, Ilha do Cardoso, Parque Estadual de Franco da Rocha, Parque Estadual da Cantareira e Agudos. A viagem para Vinhedo e as saídas em Piracicaba foram realizadas em ônibus fretado.

Os dois primeiros acompanhamentos foram realizados em maio de 2002, como "piloto", a fim de que a pesquisadora se familiarizasse com a utilização de diversos equipamentos disponíveis para coleta de dados: máquina fotográfica digital Cânon A40, filmadora Panasonic M9000, gravador AIWA de fita cassete e cadernetas de campo. Como o resultado final desses acompanhamentos foi considerado satisfatório, os dados coletados foram incorporados.

Seguem explicações adicionais sobre as técnicas: o caderno de campo foi utilizado para agrupar as anotações feitas antes, durante e depois do acompanhamento in loco, com dados objetivos e subjetivos observados e anotados pela pesquisadora; incluindo desde data, o percurso realizado, a duração da atividade e até as impressões pessoais sobre o evento e os participantes.

A documentação videográfica e gravação em fitas $K 7$ foram utilizadas sempre que possível.

Cabe comentar que apenas uma empresa proibiu a documentação com fotos e filmagem, portanto cada momento distinto de trabalho de campo foi filmado, fotografado e gravado, apenas com o assentimento dos presentes e/ou empresas a fim de se compor um rol de documentos que desse maior confiabilidade tanto para alimentar a pesquisa como para ilustrar a diversidade de ambientes percorridos, e facilitar posterior análise. 
Optou-se por apresentar algumas fotos destas etapas no corpo do trabalho apenas com finalidade ilustrativa, porém sem necessidade de identificação direta do egresso.

\begin{tabular}{|c|c|c|c|}
\hline Acompanhamento in loco & Mês/ano & $\begin{array}{l}\text { Atividade dos } \\
\text { egressos }\end{array}$ & Público-alvo \\
\hline $\begin{array}{l}\text { 1. Auriga e Hercules } \\
\text { Ilha do Cardoso/SP }\end{array}$ & Maio/2002 & $\begin{array}{l}\text { Curso de Educação } \\
\text { Ambiental* }\end{array}$ & $\begin{array}{l}\text { Estudantes de } \\
\text { Biologia }\end{array}$ \\
\hline $\begin{array}{l}\text { 2. } \quad \text { Crux } \\
\text { Piracicaba/SP }\end{array}$ & Maio/2002 & Estudo do meio & $\begin{array}{l}\text { Estudantes do Ens. } \\
\text { Fundamental }\end{array}$ \\
\hline $\begin{array}{l}\text { 3. Indus } \\
\text { Agudos/SP }\end{array}$ & Set/2002 & $\begin{array}{l}\text { Educadora ambiental } \\
\text { do centro de visitantes }\end{array}$ & $\begin{array}{l}\text { Pré-escola e } \\
\text { seminaristas }\end{array}$ \\
\hline $\begin{array}{l}\text { 4. Cassiopeia } \\
\text { São Paulo/SP }\end{array}$ & Set/2002 & $\begin{array}{l}\text { Curso sobre consumo } \\
\text { responsável }\end{array}$ & Educadores em gera \\
\hline $\begin{array}{l}\text { 5. Crux } \\
\text { Piracicaba/SP }\end{array}$ & Out/2002 & Estudo do meio & $\begin{array}{l}\text { Estudantes do Ens. } \\
\text { Fundamental }\end{array}$ \\
\hline $\begin{array}{l}\text { 6. Carina } \\
\text { Vinhedo/SP }\end{array}$ & Out/2002 & $\begin{array}{l}\text { Estudo do meio } \\
\text { HTPC }\end{array}$ & $\begin{array}{c}\text { Professoras da rede } \\
\text { pública }\end{array}$ \\
\hline $\begin{array}{l}\text { 7. Phoenix } \\
\text { Franco da Rocha e } \\
\text { Cantareira/SP }\end{array}$ & Nov/2002 & Estudo do meio & Monitores ambientais \\
\hline $\begin{array}{l}\text { 8. Cetus } \\
\text { Cananéia/SP }\end{array}$ & Nov/2002 & Curso sobre cetáceos & $\begin{array}{l}\text { Estudantes de } \\
\text { Biologia Marinha }\end{array}$ \\
\hline $\begin{array}{l}\text { 9. Chamaeleon } \\
\text { Piracicaba/SP }\end{array}$ & Jan/2003 & Intervenção social & Jornal de Piracicaba \\
\hline
\end{tabular}

Quadro 1 - Acompanhamento in loco

O último acompanhamento in loco foi registrado em janeiro de 2003, documentando uma denúncia que uma egressa estava fazendo para o jornal local sobre cortes de árvores no campus da universidade. 

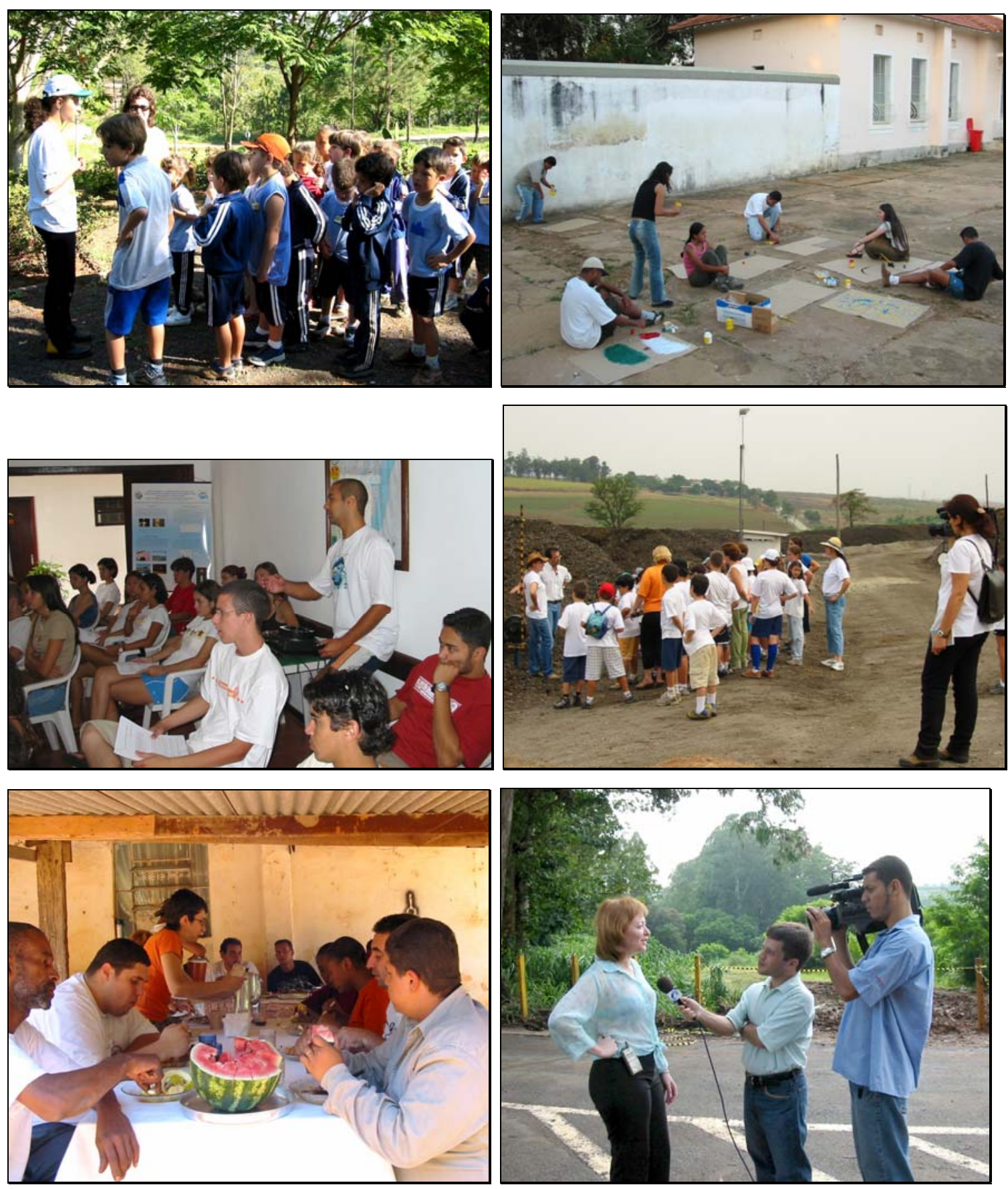

Figura 13 - Seqüência acompanhamento in loco 


\subsubsection{O trabalho de campo no $3^{\circ}$ tempo}

Teve início no final de 2003 com uma comunicação via email (Anexo K) para oito egressos, por terem o maior número de materiais coletados. Esta etapa, realizada entre janeiro e fevereiro de 2004, foi denominada "reta final" e teve como finalidade a produção de uma síntese.

Para isso, houve a "devolução" aos egressos dos documentos transcritos e digitados: o "ponto zero", Itatinga II, a entrevista semi-estruturada e o acompanhamento in loco.

Os documentos foram numerados (de um a quatro) e seguiram via correio; cada um deles tinha um título identificando-o e, uma folha a parte trazia instruções para leitura e correção das transcrições (Anexo L). Foi solicitado ainda que escrevessem uma síntese de uma página sobre a impressão global que tiveram, após as leituras e considerações.

Todo esse material deveria ser enviado para a pesquisadora via correio, antes do encontro para o laboratório conceitual. Nesse encontro, haveria a leitura das sínteses e a produção de uma síntese do grupo, entre outras atividades. Infelizmente, não houve a devolução desses documentos para a pesquisadora: não atenderam a demanda, justificando, na época, via de regra, o acúmulo de atividades. Mesmo assim, posteriormente, realizou-se um laboratório conceitual com três desses oito egressos.

No Quadro 2, apresentam-se os sujeitos com os totais de materiais coletados nas respectivas técnicas, fonte dos dados primários. Dos 9 estudantes que desistiram do curso no início ou ao logo dele, 4 foram suprimidos deste quadro pois não se fez uso dos dados coletados. 


\begin{tabular}{|c|c|c|c|c|c|c|}
\hline $\begin{array}{l}\text { Técnicas } \\
\text { Sujeitos }\end{array}$ & $\begin{array}{l}\text { "Ponto } \\
\text { zero" }\end{array}$ & Itatingal & $\begin{array}{l}\text { It } \\
\text { II }\end{array}$ & $\begin{array}{l}\text { Entrevista } \\
\text { semi- } \\
\text { estruturada }\end{array}$ & $\begin{array}{l}\text { Acomp. } \\
\text { in loco }\end{array}$ & $\begin{array}{c}\text { Laboratório } \\
\text { conceitual }\end{array}$ \\
\hline *Áquila & $x$ & - & - & - & - & - \\
\hline${ }^{*}$ Corvus & $x$ & $x$ & - & - & - & - \\
\hline${ }^{\star}$ Equuleus & $x$ & $x$ & $x$ & - & - & - \\
\hline *Grus & $x$ & - & - & - & - & - \\
\hline * Lyra & $x$ & $x$ & $x$ & - & - & - \\
\hline Apus & - & - & - & $x$ & - & - \\
\hline Auriga & $x$ & $x$ & $x$ & $x$ & $x$ & $x$ \\
\hline Capricornus & $x$ & $x$ & $x$ & - & - & - \\
\hline Carina & $x$ & - & - & $-* \star$ & $x$ & - \\
\hline Cassiopeia & - & $x$ & $x$ & $x$ & $x$ & $x$ \\
\hline Centaurus & $x$ & $x$ & $x$ & $x$ & - & - \\
\hline Cetus & - & $x$ & $x$ & $x$ & $x$ & - \\
\hline Chamaeleon & $x$ & $x$ & $x$ & - & $x$ & - \\
\hline Circinus & $x$ & $x$ & $x$ & $x$ & - & - \\
\hline Columba & - & $x$ & $x$ & $x$ & - & - \\
\hline Corona & $x$ & - & - & $x$ & - & - \\
\hline Crater & $x$ & $x$ & $x$ & $x$ & - & - \\
\hline Crux & $x$ & $x$ & $x$ & $x$ & $x$ & - \\
\hline Cygnus & $x$ & $x$ & $x$ & $x$ & - & - \\
\hline Delphinus & - & $x$ & $x$ & $x$ & - & - \\
\hline Draco & $x$ & $x$ & $x$ & $x$ & - & - \\
\hline Fornax & $x$ & $x$ & $x$ & - & - & - \\
\hline Gemini & $x$ & $x$ & - & - & - & - \\
\hline Hercules & $x$ & $x$ & $x$ & $x$ & $x$ & $x$ \\
\hline Horologium & $x$ & $x$ & $x$ & - & - & - \\
\hline Hydra & - & $x$ & $x$ & $x$ & - & - \\
\hline Indus & - & $x$ & $x$ & $x$ & $x$ & - \\
\hline Phoenix & $x$ & $x$ & $x$ & $x$ & $x$ & - \\
\hline Taurus & $x$ & $x$ & $x$ & $x$ & - & - \\
\hline Totais & 22 & 24 & 22 & 18 & 9 & 3 \\
\hline
\end{tabular}

Quadro 2 - Obtenção de dados primários

* Estudantes que desistiram do curso de especialização

${ }^{\star *}$ A entrevista semi-estruturada foi realizada, porém a fita foi extraviada antes da transcrição. 
No Quadro 3, estão os materiais que os estudantes produziram e que após leitura, forneceram os dados secundários para análise e discussão.

\begin{tabular}{|c|c|c|c|}
\hline Sujeitos & $\begin{array}{l}\text { Projeto de } \\
\text { intervençąo }\end{array}$ & Mini-curso & $\begin{array}{l}\text { Relatório descritivo- } \\
\text { analítico }\end{array}$ \\
\hline Apus & $\mathrm{X}$ & $\mathrm{X}$ & $x$ \\
\hline Auriga & $x$ & $x$ & $x$ \\
\hline Capricornus & $x$ & $x$ & $x$ \\
\hline Carina & $x$ & $x$ & $x$ \\
\hline Cassiopeia & $x$ & $x$ & $x$ \\
\hline Centaurus & $x$ & $x$ & $x$ \\
\hline Cetus & $x$ & $x$ & $x$ \\
\hline Chamaeleon & - & $x$ & $x$ \\
\hline Circinus & $x$ & $x$ & $x$ \\
\hline Columba & $x$ & $x$ & $x$ \\
\hline Corona & $x$ & $x$ & $x$ \\
\hline Crater & $x$ & $x$ & $x$ \\
\hline Crux & $x$ & $x$ & - \\
\hline Cygnus & $x$ & $x$ & $x$ \\
\hline Delphinus & $x$ & $x$ & $x$ \\
\hline Draco & $x$ & $x$ & $x$ \\
\hline Fornax & $x$ & $x$ & - \\
\hline Gemini & - & - & - \\
\hline Hercules & $x$ & $x$ & $x$ \\
\hline Horologium & $x$ & $x$ & $x$ \\
\hline Hydra & $x$ & $x$ & $x$ \\
\hline Indus & $x$ & $x$ & $x$ \\
\hline Phoenix & $x$ & - & - \\
\hline Taurus & $x$ & $x$ & $x$ \\
\hline Totais & 22 & 21 & 20 \\
\hline
\end{tabular}

Quadro 3 - Obtenção de dados secundários 


\subsection{Os três olhares}

As etapas descritas foram organizadas e aconteceram, a partir da observação participante ${ }^{46}$ para a coleta de dados, numa abordagem que dialoga com o campo da etnografia ${ }^{47}$ pela necessidade de adentrar no espaço de atuação dos participantes; da pesquisa-ação por avaliar e refletir a própria prática; e do estudo de caso, por ter características próprias, únicas.

Sendo assim, as diferentes técnicas utilizadas para compor o cardápio de documentos: questionários com perguntas abertas e semi-abertas, depoimentos, entrevistas semi-estruturadas, acompanhamento in loco, caderno de campo e laboratório conceitual, geraram dados em níveis de profundidade e especificidade distintos, conforme nos recomenda Becker:

"No processo de coleta de dados, o observador-participante se engaja em várias atividades diferentes. Pode-se distinguir diversas modalidades de procedimento, dependendo do grau no qual se é participante assim como observador (...). Ele tenta registrar este material tão completamente quanto possível por meio de relatos detalhados de ações, mapas de localização de pessoas enquanto atuam e, é claro, transcrição literal das conversações" (Becker, 1999, p.119-120).

Além desses materiais, que forneceram dados primários, outros produzidos pelos estudantes foram utilizados, tais como: os projetos de intervenção educacional, o relatório descritivo analítico e a proposta de minicurso, sendo aqui considerados como dados secundários. O que fomentou e corroborou a análise do curso, da disciplina e dos conceitos foi o impacto positivo que esses causaram ao contribuírem para a coesão e sinergia do grupo.

\footnotetext{
${ }^{46}$ Segundo Barbier (1985, p.97), "requer do pesquisador uma atitude de "simpatia", sensível à personalidade das pessoas".

${ }^{47}$ Segundo Spradley (1979), citado por Ludke (1986, p.14), etnografia é a descrição de um sistema de significados culturais. Na mesma obra, alguns critérios são apresentados por outros autores como necessários na pesquisa etnográfica e que nos parecem adequados aqui: "o pesquisador deve realizar a maior parte do trabalho de campo pessoalmente", "o trabalho de campo deve durar pelo menos um ano escolar", combinar vários métodos de coleta, apresentar grande quantidade de dados primários, entre outras.
} 
Para que as respostas possam dar indicativos da percepção desse público a respeito dessas questões, os trabalhos de campo alternaram-se com os de laboratório (organizar o material, tabular os questionários, transcrever as entrevistas, selecionar as fotos, enviar correspondências para os participantes, ler exaustivamente as transcrições e tabulações) contribuindo para organizar os resultados e a discussão em blocos, utilizando algumas opiniões dos participantes. 


\section{RESULTADOS E DISCUSSÃO}

"Se a síntese pudesse ser efetiva, se minha experiência formasse um sistema fechado, se a coisa e o mundo pudessem ser definidos de uma vez por todas, se os horizontes espaçotemporais pudessem, mesmo idealmente, ser explicitados e o mundo pudesse ser pensado sem ponto de vista, agora nada existiria, eu sobrevoaria o mundo e, longe de que todos os lugares e todos os tempos se tornassem reais ao mesmo tempo, todos eles deixariam de sê-lo porque eu não habitaria nenhum deles e não estaria engajado em parte alguma" (Merleau-Ponty, 1999, p. 445).

Para apresentação e discussão dos resultados serão utilizados os dados primários e secundários, que foram obtidos em circunstâncias já descritas anteriormente, e que tiveram como decorrência buscar indicativos sobre a utilização de estudos do meio e a sua contribuição para a formação de educadores ambientais, atingindo-se objetivos educacionais e do ambientalismo relacionado ao conceito de pertencimento.

Essa diversidade de técnicas ${ }^{48}$ e de documentos gerados, que caracteriza a pesquisa qualitativa, produziu uma grande quantidade de dados que, selecionados, foram triangulados entre si, como recomenda Minayo (1998), Ludke (2001), Thiollent (1985), Denzin (1977), entre outros.

"O observador não pretende comprovar teorias nem fazer generalizações estatísticas. O que busca, sim, é compreender e

\footnotetext{
${ }^{48}$ Compreende-se por técnica as diferentes formas de levantamento de dados, como por exemplo, questionários com perguntas semi-abertas, entrevistas semi-estruturadas, depoimentos que, posteriormente, foram tabulados, transcritos, selecionados.
} 
descrever a situação, revelar seus múltiplos significados, deixando que o leitor decida se as interpretações podem ou não ser generalizáveis, com base em sua sustentação teórica e em sua plausibilidade" (André, 1997, p.48).

De posse dos documentos colecionados durante e após o curso e a disciplina, e, através de uma leitura cuidadosa, surgiram algumas perguntas aparentemente simples, como por exemplo: quais foram as contribuições do curso? Quais compreensões eles têm sobre estudos do meio? E sobre o conceito de pertencimento? Há relações entre estudos do meio e pertencimento? Quais são elas?

Usou-se a triangulação para aproximar e comparar os depoimentos entre os sujeitos ao longo dos três tempos da pesquisa. Optou-se por transcrever as respostas escritas e gravadas tal qual foram elaboradas.

Diante desses materiais e dos questionamentos passou-se a olhar para as técnicas utilizadas, em dimensões denominadas "olhar vertical", "olhar horizontal" e "olhar transversal".

\subsection{Olhar vertical}

Os dados dos diferentes sujeitos foram triangulados, analisados, relacionados e apresentados, no mínimo, em dois itens: estudos do meio e pertencimento. No entanto, dentro de algumas técnicas, será apresentado ainda, em outros itens, alguns dados que foram considerados relevantes para a pesquisa e que não se enquadram diretamente em estudos do meio ou pertencimento.

Sendo assim, apresentam-se os resultados numa seqüência cronológica em relação à coleta: "ponto zero"; Itatinga I; Itatinga II; projetos de intervenção; minicursos; relatório descritivo-analítico; entrevista semi-estruturada; acompanhamento in loco e laboratório conceitual. Destaca-se o fato de que os projetos de intervenção, os minicursos e o relatório descritivo-analítico foram produzidos para o curso, sem a interferência direta da pesquisadora, como nas outras técnicas. 


\subsection{1 "Ponto zero"}

Aqui serão apresentadas algumas respostas dadas no "ponto zero", visando demonstrar a diversidade do conhecimento inicial dos estudantes sobre estudos do meio, bem como verificar a presença do conceito de pertencimento.

\subsubsection{Estudo do meio}

Quando Ihes foi perguntado se já haviam realizado algum estudo do meio, obteve-se um total de 14 respostas afirmativas (56\%) do total de 24 , sendo que trazem referências, via de regra, a realização do estudo do meio em áreas naturais protegidas do Brasil, com observação de flora e fauna, como pode-se observar em algumas respostas detalhadas:

Cygnus: "No Espírito Santo, tive a oportunidade de conhecer um pouco da biologia marinha e algumas atividades relacionadas com hortas, caminhadas na mata. No Pantanal, trabalhamos com levantamento de pegadas, alimentação, captura, flora e fauna local, predação. Na Reserva biológica de Una, trabalhei três meses com morcegos, e pude observar vários animais, plantas, o impacto do homem na natureza, entre outras experiências interessantes".

Corona: "Alguns, como em São Luis do Paraitinga, Parque Guapituba $(A B C)$, estudo de mananciais $(A B C)$ e estudo em Paranapiacaba na reserva biológica, junto aos alunos".

Há respostas mais sintéticas como:

Grus: "Projeto: aspectos da fauna e flora do rio Tibagi e ecologia de praias arenosas".

Há, também, ainda alguns relatos de estudos do meio em áreas urbanas e com populações humanas, como por exemplo:

Áries: "Em várias ocasiões no curso (praças, ambientes adjacentes, favelas, zona urbana). Na área Química, nos espaços industriais".

Horologium: "Na Universidade, com trabalhos realizados em Rio Claro sobre população, com coleta de dados, entrevistas e 
tabulações dos dados. Fiz alguns trabalhos com meus alunos a respeito dos bairros onde moravam".

Três estudantes (12\%) afirmaram que nunca realizaram um estudo do meio e oito estudantes (32\%) deram respostas evasivas, deixando dúvidas quanto à compreensão da pergunta, como pode ser verificado no seguinte exemplo:

Taurus: "Apenas em oportunidades de dinâmicas de grupo em atividades específicas".

Esse percentual de $44 \%$ de respostas negativas e evasivas pode demonstrar tanto uma "necessidade" desse grupo em responder a questão por estar ingressando no curso, quanto um problema de compreensão da questão.

Todavia, esse resultado aproxima-se dos percentuais verificados por Pegoraro (2000), quando pesquisou a prática de professores do ensino fundamental e médio de escolas da rede pública da região de Campinas, pois obteve que $48 \%$ dos entrevistados não realizam atividades de estudo do meio e $24 \%$ realizam algumas vezes.

Entre as 24 respostas obtidas sobre a compreensão de estudo do meio, apenas uma delas foi "nenhuma", dada por Crater. Pode-se afirmar que há uma certa diversidade de compreensões, sendo assim, aproximadamente 56\% das respostas foram consideradas mais complexas, de acordo com Pontuschka $(1994,1998)$ e Hoehne (1937), por apontarem como importantes a observação, a descrição, a compreensão da dependência dos seres, a necessidade de mudanças, entre outras afirmações.

O critério para seleção dos trechos foi exemplificar esse gradiente de compreensões, apresentando-se inicialmente os considerados mais significativos em relação a essa literatura, ou seja, mais complexos. Seguem-se algumas que foram destacadas após proceder-se à leitura e seleção de trechos mais significativos:

Horologium "É o reconhecimento de uma área ou lugar, que envolve estudos sobre suas características humanas, sociais e naturais. Depois de realizadas visitas, entrevistas, pesquisas, fotos, assuntos de jornais e revistas, a comparação entre 0 
passado e o presente, tirar conclusões, reflexões e definir ações para atuar ou melhorar nesse meio".

Grus "Significa conhecer com propriedade os mais variados aspectos da vida em dado local, sabendo detectar a natureza das relações e, principalmente, não se considerar como o observador desta trama. É necessária a clareza de admitir a dependência de todos os seres entre si, inclusive o homem, como um ser ativo ao processo, quer seja com ações positivas ou negativas".

Essas respostas estão em sintonia com a teoria: "não é mais possível olhar paisagens das cidades ou até mesmo do campo sem enxergar problemas ambientais que comprometam a qualidade de vida das populações" (Pontuschka, 1998, p. 7).

Em outras respostas, $24 \%$ delas, depreende-se uma visão mais biológica/técnica; e, em 20\%, elas foram consideradas evasivas, como as seguintes:

Capricornus: "Observar, entender e relacionar os fatores e os elementos que fazem parte do meio".

Fornax: "Fundamental para uma vida saudável".

Um explicação provável para esses valores pode vir do fato de a formação acadêmica e a experiência profissional ser bastante diferenciada entre eles. Outra possibilidade é o fato de o estudo do meio não ser uma prática constante na vida escolar, sendo confundido, muitas vezes, com as "viagens", "excursões" ou "passeios".

Ao buscar-se a diversidade de compreensões sobre a relação entre estudo do meio e aprendizagens, evidenciam-se, em 50\% das respostas, indicações para que a aprendizagem ocorra:

Fornax: "Através da sensibilização dos estudantes e da comunidade com pesquisas, trabalho de campo, oficinas, vídeos, debates (...)".

Auriga:"Muitas que propiciem o desenvolvimento social, afetivo, cognitivo e lógico matemático, contribuindo para a informação e formação integral do indivíduo, proporcionando ao sujeito condições de melhorar sua qualidade de vida". 
Cassiopeia: "Quando se vivencia uma situação (...), suas observações, sensações e percepções são muito mais concretas e próximas da realidade".

Hercules: "Uma aprendizagem de natureza interdisciplinar com a fusão das mais variadas áreas de produção do conhecimento humano, utilizando as capacidades sensitivas e as estruturas de cognição de maneira planejada".

Draco: "O aprendizado mais importante, acredito eu, é o respeito que por sua vez desenvolve uma sensibilidade e admiração fundamentais, para que possamos aprender cada vez mais e também ensinarmos com grande entusiasmo e prazer".

Phoenix: "O exercício da interpretação é um exercício de crítica. A percepção do mundo exterior e das necessidades anteriores é o ponto de partida para a elaboração de alternativas construtivas e a base para qualquer ação relativa ao meio ambiente".

Há dois processos relacionados à aprendizagem que merecem ser destacados a partir desses depoimentos: os cognitivos e os da percepção e emoção, que aparecem como complementares. Assim, os sentidos, as sensações, as experiências, o prazer e até a contemplação aparecem como elementos importantes, que contribuem para o ensino-aprendizagem num ensino não "bancário ${ }^{49 " . ~}$

“(...) toda prática educativa demanda a existência de sujeitos, um que, ensinando, aprende, outro que, aprendendo, ensina, daí o seu cunho gnosiológico; e existência de objetos, conteúdos a serem ensinados e aprendidos; envolve o uso de métodos, de técnicas, de materiais; implica, em função de seu caráter diretivo, objetivo, sonhos, utopias, ideais. Daí a sua politicidade, qualidade que tem a prática educativa se ser política, de não poder ser neutra" (Freire, 2000, p.77-78).

${ }^{49}$ Alusão feita ao termo "educação bancária" propalado por Freire (2000), em que o educador é um mero transmissor de informações e o estudante o receptáculo capazes de memorizar e reproduzir. 
Atentos à necessidade de uma educação libertadora e complexa, e ainda, do seu caráter gnosiológico, pois atribui valor ao conhecimento e às suas condições, é que devem ser organizados os estudos do meio. Essa concepção política, que busca autonomia, tem em seu objetivo a proposta de ser solidária; ou como Morin (2003) coloca: "Uma educação que tem por objetivo uma concepção complexa da realidade e que efetivamente conduzisse a ela, estaria colaborando com os esforços que visam atenuar a crueldade do mundo" (Morin, 2003, p. 59).

\subsubsection{Pertencimento}

Do total de questionários analisados, em nenhum deles há menção direta à palavra pertencimento nas respostas, no entanto, em cinco deles pode-se depreender esse conceito, através dos trechos selecionados para discussão. Ao responder a questão 3, sobre a trajetória profissional, Cygnus, que trabalha com adolescentes em liberdade assistida, coloca:

Cygnus: "Partindo das questões ambientais, para que o adolescente faça seu projeto de vida, perceba qual o seu papel com ele mesmo, com o outro, social e o biológico".

Draco: "Acho que minha trajetória profissional apenas se aproxima do meio ambiente na medida em que me sensibilizo a cada dia da necessidade premente de que as pessoas incorporem em seus valores pessoais o respeito e o entendimento a respeito do ambiente em que vivem".

Grus, ao responder a questão 7, sobre estudos do meio e aprendizagem:

"Talvez a coisa mais difícil na Educação Ambiental seja despertar nas pessoas a capacidade (quase morta) de olhar, sentir e desenvolver um forte elo com tudo que o rodeia".

Nessa mesma questão e aproximando-se da resposta de Grus, pois prevalece também a importância dos sentidos, Crux comenta o trabalho que vem fazendo em escolas rurais, inclusive junto às famílias e comunidade:

Crux: "Temos um compromisso em alfabetizá-los, mas um maior compromisso em saber fazer o uso adequado do meio em que vivem. Vivem no meio rural e desconhecem o próprio meio, estão 
aprendendo a parar para observar, sentir e sentir os efeitos das transformações".

Um dos aprendizados relevantes citado por Auriga, ao responder a questão oito, é o de "como o homem está inserido no ecossistema social e natural".

Nesses trechos, podem-se identificar as duas compreensões sobre pertencimento abordadas no capítulo teórico: a de Grus e Crux, aproximando-se de Unger (2001), numa visão mais integral da relação ser humano e ambiente; a de Cygnus apresenta conexão com a idéia de pertencimento expressada por Weil (2001): de busca por autonomia e emancipação.

Os estudos do meio, talvez, possam contribuir para criar e fortalecer os elos a que Grus se refere: de despertar a capacidade de olhar e sentir; à necessidade de que as pessoas incorporem o respeito ao ambiente, sugerida por Draco e Auriga; ou ainda, à importância da percepção dos papéis do ser humano como Cygnus coloca.

\subsubsection{Itatinga I}

Os dados utilizados referem-se ao resultado da avaliação da disciplina "Reconhecendo o meio ambiente", que abordou técnicas específicas de estudos do meio além de outras. As outras "correntes" teóricas: "aprendizado na natureza", "jogos cooperativos" e "educação ao ar livre" também podem ser compreendidas como estudos do meio, principalmente dentro da concepção pedagógica apontada. A tabulação dos 22 questionários, aplicados ao final da disciplina, encontra-se no APÊNDICE 2.

\subsubsection{Estudo do meio}

Pode-se afirmar que tanto as atividades "conceituais" quanto as "sociais" da disciplina foram consideradas como partes de um estudo do meio complexo, a fim de atingir seus objetivos. Foram 18 itens avaliados através dos conceitos "bom", "razoável" ou "ruim"; sendo que em 17 deles houve mais de 50\% de "bom". Não houve atividades conceituais avaliadas como "ruim". Para algumas delas foi atribuído, espontaneamente, o conceito de "ótima" ou "excelente". 
Conforme pode-se observar na Tabela 2, as atividades conceituais obtiveram "bom" na visão de 59\% dos estudantes, sendo que o "bom" para 95,5\% e 100\% deles foi o "aprendizado na natureza" e "educação ao ar livre", respectivamente.

A avaliação da atividade de "estudo do meio" ficou aquém da esperada, pois apenas 59\% dos estudantes avaliaram-na como "bom". A pressão e a expectativa por esse momento era grande, pois muitos deles tinham interesse profissional (professores, educadores e pedagogas) em aprender a técnica e os outros estavam bastante curiosos.

Tabela 2 - Avaliação das atividades "conceituais"

\begin{tabular}{llllll}
\hline & $\begin{array}{l}\text { Aprendizado na } \\
\text { natureza } \\
(\%)\end{array}$ & $\begin{array}{l}\text { Estudo } \\
\text { meio } \\
(\%)\end{array}$ & $\begin{array}{l}\text { do Jogos } \\
\text { cooperativos } \\
(\%)\end{array}$ & $\begin{array}{l}\text { Educação ar livre } \\
(\%)\end{array}$ & $\begin{array}{l}\text { Ativid. } \\
\text { Solo } \\
(\%)\end{array}$ \\
\hline \hline Bom & 95,5 & 59 & 86,5 & 100 & 68 \\
Razoável & - & 36,5 & 13,5 & - & 32 \\
Ruim & - & - & - & - & - \\
Não respondeu & 4,5 & 4,5 & - & - & - \\
\hline
\end{tabular}

Destacam-se algumas frases que justificaram esse resultado:

"Trabalhamos em grupo, montamos uma apresentação".

"(...) para conhecermos por nós mesmos o local onde estamos".

"Ampliou meus conhecimentos e percepção".

Os 36\% que avaliaram como razoável, justificaram pelo seguinte:

"Não entendi direito o que foi pedido".

"Falta de clareza na apresentação da proposta e falta de apoio do grupo".

"Faltou tempo, houve muita ansiedade". 
Numa reflexão posterior, considerou-se que alguns fatores também poderiam ter contribuído para esses resultados, tais como:

1. o horário escolhido para a atividade de "estudo do meio" foi após o almoço, o pessoal estava meio sonolento e cansado;

2. o local escolhido para a explicação da atividade foi no gramado em frente ao refeitório, facilitando a dispersão e interferências, pois cada um estava num "clima/tempo" diferente;

3. a estratégia utilizada para introdução da atividade foi de leitura individual (em silêncio) da parte teórica do guia de campo e depois em subgrupos; assume-se que, nessa circunstância, não foi adequada;

4. após definir-se o local onde iriam preparar um "mini" estudo do meio, seria importante discutirem qual a abordagem a ser adotada; dividir tarefas e responsabilidades nos subgrupos; no entanto, desconsideraram a importância dessa etapa preparatória, justificando-a também pela ansiedade do grupo.

As situações de conflito ou desentendimento não podem ser menosprezadas, pois quando são discutidas e enfrentadas, contribuem para a coesão do grupo. Raimo (2000), ao descrever uma viagem com um pequeno grupo de montanhistas, escalando o Blanca Peak, Colorado, Estados Unidos, comenta que há vários "obstáculos" a serem vencidos: o físico, o psicológico, o social. "Vivenciamos desafios, riscos, desentendimentos, limites, alegrias" (Raimo, 2000, p. 112). Mas o aprendizado que fica, de vencer-se os obstáculos, carrega-se para a vida toda:

"O aprendizado físico, social e pessoal propiciado pela educação experiencial ao ar livre é simplesmente fascinante: cada um é seu próprio objeto de estudo e as suas relações consigo, com os outros, com o ambiente e com as tarefas à mão são o professor" (Raimo, 2000, p.113).

Assim, compreende-se que está imbricada a relação da aprendizagem através de vivências, da superação de desafios e limites, com o fortalecimento das relações inter e intrapessoais, podendo ser uma explicação para o sucesso e repercussões positivas da disciplina ministrada. É provável que o "valor" dessa aprendizagem esteja na transformação que ela proporciona, na busca de conhecimento sobre si, os outros e, o mundo. 


\subsubsection{Pertencimento}

Após leitura exaustiva das respostas aos questionários, não se pode detectar alguma referência explícita ou implícita ao conceito de pertencimento. No entanto, deve-se considerar esse resultado com ressalvas, pois em Itatinga II, realizado logo após, o conceito está implícito assim como, nos projetos de intervenção e minicurso explícito, sendo associado, por diversas vezes, inclusive, à disciplina "Re-conhecendo o meio ambiente". O próprio fato de eles se referirem, doravante, a essa disciplina como "Itatinga" pode ser um indício de que contribuiu para o sentimento de pertença ao local, às técnicas e, principalmente, ao grupo, como se verá adiante.

\subsubsection{Atividade solo}

Com o intuito de obter mais confiabilidade nas respostas, não foi solicitado aos participantes que se identificassem ao responder o questionário. Aproximadamente $68 \%$ dos estudantes atribuíram "bom" à atividade solo. Entre os motivos apontados para este resultado, destacam-se:

"Consegui ficar sozinha, me observando, me sentindo, um desafio escrever a carta, estou ansiosa para lê-la daqui a 6 meses".

"É tão simples e tão difícil de se fazer".

"Profícuo e gostoso".

"Me encontrei, parei de fugir de alguém que precisava encontrar há 26 anos!".

"Para podermos entender melhor nosso papel neste meio da Educação Ambiental".

"Oportunidade de reflexão, exercício do olhar, pacificação e harmonização interior".

"Gosto de ficar sozinha de vez em quando, neste lugar fiquei só e não senti solidão".

"Encontrei com alguém que não via há um tempão".

A sugestão que apontaram para essa atividade foi de que houvesse mais tempo para sua realização. 
Entre os que consideraram "razoável", a maioria justificou na resposta pelo fato de chegarem atrasados à atividade (na noite anterior havia sido a "festa surpresa") e terem realizado a atividade em menos tempo. Apenas um apresentou outro motivo:

"Embora importante, não estava no clima de ficar sozinha".

Queria saber se houve alguma atividade em especial, em relação a todos os encontros presenciais do curso de especialização - e qual foi - que contribuiu para a percepção e aprendizagem sobre o meio ambiente. Dez estudantes responderam em geral: "As atividades se completaram, houve uma evolução, a viagem foi fundamental". Dois estudantes responderam que foi o "solo", entre outras seis atividades realizadas durante o curso e mencionada por eles, demonstrando que, mesmo dentre várias atividades realizadas, essa atividade também se destacou.

Dentre os fundamentos dos programas de educação ao ar livre (outdoor education) que Luckner \& $\operatorname{Nadler}^{50}$ (Barros, 2000) descrevem, há quatro estágios que a envolvem: vivendo a experiência, refletindo, generalizando, aplicando; e, entende-se que a atividade solo poderia integrar um deles, o de refletir sobre a experiência. De acordo com esses autores, para garantir o aprendizado, é necessário o processo de reflexão que pode ser solitário ou em grupo: o solo vem permitir às pessoas que pensem sozinhas a respeito do que foi visto e sentido, visando sedimentar a experiência e aprendizado.

\subsubsection{Itatinga II}

Os depoimentos gravados foram obtidos a partir da seguinte pergunta: "Nesses quatro dias de viagem, o que houve de contribuição para sua atuação profissional e sua trajetória pessoal?". Do total de 22 participantes da disciplina, Gemini pediu para desgravar sua declaração; Corvus não estava presente nesse momento, portanto, nessa análise foram considerados 20 depoimentos que foram gravados com todos envolvidos, num clima de grande emoção, de encerramento das atividades de campo.

\footnotetext{
${ }^{50}$ LUCKNER, J.L.; NADLER,R.S. Processing the experience: strategies to enhance and generalize learning. Dubuque: Kendall/Hunt, 1992.
} 


\subsubsection{Estudo do meio}

Dos trechos que se seguem, destacaram-se algumas referências diretas que foram feitas sobre aprendizagem, confirmando o potencial dessa atividade como contribuição na escola e, também, fora dela. Em 50\% dos depoimentos os estudantes afirmam isso. Apresenta-se ainda uma breve reflexão sobre o corpo e a sensorialidade, pois nessas situações a sua valorização é imprescindível para aprendizagem.

Hydra: "Estudo do meio a gente sempre acha que sabe um pouquinho, mas aprendi bastante, ainda mais com os erros. Com o erro a gente aprende muito mais".

Cassiopeia: "Esta foi a maior descoberta, pois posso incorporar ou reproduzir num contexto maior. Pensei que não tivesse noção de estudo do meio, mas tenho, mais do que imaginava".

Indus: "Neste encontro aprendi muito a observar as pessoas, a contribuição numa frase, num jeito de olhar. Quanta riqueza num ser humano quando se planeja alguma coisa...não sei se foi o caso de vocês...vocês sentaram e conseguiram friamente traçar isso. Eu, no lugar de vocês, estaria feliz, alegre por conseguir um grupo grande evoluir deste jeito. É o must do planejamento(...). Saio daqui como um ser humano melhor".

Quanto à dúvida suscitada por Indus, sobre o planejamento:

"A resposta está em como os instrutores planejam e manejam a progressão das atividades, rota e aulas que os alunos estão vivenciando, aprendendo, praticando e assim por diante. Resumidamente, a idéia é: conte, demonstre, supervisione, delegue - educação para autonomia" (Raimo 2000, p. 121).

Destaca-se que, para contribuir com essa intenção de uma educação para a autonomia, que Raimo (2000) aponta, houve uma série de atividades sociais, propositais, quando pequenas "tarefas" foram requeridas, como por exemplo: preparar 
coletivamente o café da manhã, aquecer os alimentos para o jantar e lavar a louça depois, e, até solicitadas por eles, como fazer um bolo de chocolate, etc.

Fica explicitado com os depoimentos de Indus, Chamaeleon e Cygnus que a aprendizagem não se restringe apenas aos conteúdos, mas também ao relacionamento e à convivência com a realidade: ${ }^{51}$.

Chamaeleon: "Todos nós temos um objetivo mais ou menos parecido de estar levando este carinho que a gente tem com o ambiente, para as sociedades. Se nós vamos trabalhar com as sociedades, temos que estar fazendo estudos de meio (...)".

Cygnus: "Cada vez que vou para o campo é uma experiência diferente: são pessoas diferentes. A experiência de campo foi 10 e clareou bastante coisa com os meninos (em liberdade assistida), que é um público difícil. Foi muito bom e quero aprender mais e poder estar compartilhando".

Cetus: "(...) aprendi muita coisa, pois tenho mais experiência em técnica. Tenho certeza de que valeu bastante a pena, principalmente trabalhar em grupo. Estou com várias idéias que posso estar aplicando".

Esse potencial dos estudos do meio virem a contribuir para a compreensão e a transformação da realidade é reafirmado por Mendonça (2003):

"Ao contrário da tentativa de isenção, os estudos do meio devem assumir que, além de um momento de conhecimento, podem se tornar um ato de inserção política. Se a realidade precisa ser transformada, é a partir de postura crítica, ações e engajamento que se caminha nessa direção. Se os alunos são transformados em pesquisadores críticos, eles podem vir a conduzir seu próprio processo de libertação da realidade opressiva, o objetivo da educação" (Mendonça, 2003, p. 45).

${ }^{51}$ Em consonância com os quatro pilares da educação, enunciados por Delors (2000): aprender a conhecer, a fazer, a viver juntos e a ser. 
Cabe lembrar que se perguntou a respeito das contribuições da disciplina, portanto há fortes indícios de que o objetivo geral da disciplina, de "contribuir para a formação de educadores ambientais através da vivência de campo e da construção coletiva de conhecimentos relacionados a utilização do entorno como recurso pedagógico" foi atingido, pelo menos com esse subgrupo, na medida em que os estudantes afirmaram que houve aprendizagem através dessa disciplina.

Para Mendonça (2003), um estudo do meio é considerado uma atividade de Educação Ambiental, sendo uma "oportunidade maravilhosa para que esses novos conceitos sejam vivenciados, trabalhados, digeridos e assimilados, uma vez que essa atividade implica em sair do cotidiano, caminhar, exercitar o corpo e expor-se ao novo" (Mendonça, 2003, p. 13).

Sobre essa reflexão a autora conclui que o "novo" pode referir-se aos espaços, horários, idéias e até formas de pensar.

Importante, também a questão do corpóreo que foi mencionada:

Chamaeleon: "O que aprendi aqui foi estar me entrosando melhor, participando dos jogos. Eu tenho dificuldades de participar de jogos, tenho medo de me machucar, eu caí duas vezes e achei muito bom, foi gostoso voltar com o corpo roxo".

Considera-se pertinente e oportuna a proposta de reflexão sobre o corpo no estudo do meio, pois é o deslocamento dele para situações diferenciadas e das suas apropriações que se está falando. Merleau-Ponty (1999) afirma que o seu corpo "não é apenas um objeto entre todos os outros objetos", ele é um complexo de qualidades entre outros corpos, é sensível, pois ressoa aos sons e vibra para as cores.

Para o filósofo francês, o "corpo próprio é ao mesmo tempo objeto constituído e constituinte em relação a outros objetos"; isto é, há duas possibilidades:

"ou eu me considero no meio do mundo, inserido nele por meu corpo, que se deixa investir por relações de causalidade, e então "os sentidos" e "o corpo" são aparelhos materiais e não conhecem absolutamente nada (...). Ou então (...) é preciso que eu saia do constituído, daquilo que é em si, e apreenda por reflexão um ser para quem o objeto possa existir. Ora para que o objeto possa existir em relação ao sujeito, não basta que este "sujeito" o 
envolva com o olhar ou o apreenda (...), é preciso ainda que ele saiba que o apreende ou o olha, que ele se conheça apreendendo ou olhando (...)" (Merleau-Ponty, 1999, p. 317- 318).

Merleau-Ponty (1999) exprime a necessidade de se ter consciência, pressupondo para isso que se deva perceber que se está percebendo e, ao fazer isso, atravessam certas "aparências subjetivas", interpretando sensações próprias na perspectiva da história individual. É possível que essa venha a ser uma das contribuições dos estudos do meio: auxiliar na construção da história não só individual, mas também coletiva, partindo-se das interpretações das próprias sensações.

\subsubsection{Pertencimento}

Depreendeu-se nos depoimentos alguns trechos que exprimem duas impressões relacionadas ao termo pertencimento: a primeira revela, em 15\%, o sentido de enraizamento político segundo Weil (2001) e Morin (2000):

Circinus: "Fiz um estudo do meio agora no fim do ano. Passei uns dias no campo fazendo levantamento, conhecendo o lugar do meu projeto. Foi numa cidade que me cativou muito. Estava tão corrido o trabalho (...) fui percebendo as características da cidade e aí que fui entrando no ritmo. E Canaã tem a peculiaridade que é uma região de assentamento, tem pessoas de vários lugares (...) O sentimento de raiz é quase nulo lá. As pessoas são muito distantes umas das outras, não só na zona rural, mas no núcleo urbano; tem as associações de grupo mas são muito fracas. As pessoas não tem sentimento de equipe, de crescer junto".

Há também uma outra impressão em que emerge um forte sentimento de identidade relacionada ao fato de "pertencer a um grupo ou coletivo", como colocada por Baptista (2004), e que foi citado em 55\% deles.

Crux: "Poderia ter sido em qualquer outro local, mas a partir do momento que fizemos o arboreto, naquela descidinha, até comentei com você, Sandra, me recordava a infância, e a partir daquele momento comecei a prestar atenção em todos os locais". 
Crux faz transparecer que houve um momento de insigth, depois da atividade de "abraçar a árvore", pois após algumas recordações da infância, sentiu-se inserida no horto de Itatinga.

Cassiopeia: "Saio daqui com um carinho grande, principalmente pelo meu cantinho, vou pôr uma placa lá".

Centaurus: "Cada vez vejo que mais legal é estar em contato com esse grupo. Tenho contato com diversos outros, mas por esse aqui tenho um carinho especial. Cada vez mais me identifico com as pessoas e quero estar perto delas".

Esses depoimentos, e também os que se seguem, parecem estar em sintonia com o pensamento de Baptista (2004) sobre a necessidade de um vínculo com uma memória comum, uma identidade universal, pois não se pode anular uma memória, elemento vital para a identidade dos homens e das comunidades.

"Falo da memória ligada aos espaços físicos de pertença, aos lugares onde se nasce, onde se dorme, onde se come, onde se ama e se sofre. Falo, pois, do tipo de memória que enraíza o homem numa determinada cultura e, deste modo, ajuda a estreitar os laços que tecem a identidade colectiva" (Baptista 2004).

O enraizamento de um grupo acontece a partir de situações específicas que podem ser favoráveis ou não, como em situações extremas de guerra e conflitos étnicos, por exemplo. Mas o que importa neste estudo é demonstrar a sua importância para os trabalhos de Educação Ambiental.

Draco: "Eu acho que o grande mérito deste curso, desde o início, está sendo não só a construção do conhecimento, mas o mais importante é a construção de uma identidade do grupo. O grupo toma corpo, ele tem personalidade. Quem trabalha com grupo sabe que esta é uma grande dificuldade: provocar harmonia, equilíbrio, onde o trabalho possa fluir (...) e atingir os objetivos. Uma coisa que eu fale ou faça está contribuindo para todos de uma forma geral. Eu fico feliz com isso. Essa construção do 
corpo, da personalidade do grupo atingiu um ponto muito interessante prá gente estar pensando (...). Temos uma cumplicidade muito grande".

Auriga: "A gente acabou se entrelaçando com todo o grupo (...)". Hercules: "Eu trabalho com grupos, há muito tempo, grupos que se formam, às vezes em uma semana, ficam juntos e depois vão embora no final de semana. Você vê isso de fora, você não se vê integrado a ele. Você está simplesmente coordenando, não faço parte deles. Sentia falta de estar vendo como é estar participando do grupo, da confiança do grupo, da relação das pessoas do grupo. Ela cresce. Acho interessante pois você pode lançar mão de alguma forma mais técnica de algumas atividades e dinâmicas onde vai trabalhar de uma forma crescente esta questão. Acredito que chegamos a um ápice, desse ótimo de formação de grupo, confiança, onde as pessoas têm a liberdade de estarem chegando, conversando, do ponto de vista da confiança mútua".

Circinus agrega as impressões do sentimento de pertença ao local, mas também o relaciona a um ato emancipatório da comunidade a qual se refere. Os outros reforçam a sentido de identidade do grupo, ou, segundo Auriga, de "entrelaçamento".

\subsubsection{Atividade solo}

Dentre todas as atividades desenvolvidas e já descritas anteriormente, chamou a atenção a repercussão positiva da última: a atividade solo. Para realizá-la, foi solicitado que escolhessem um local tranqüilo, agradável, mesmo sabendo que "a privacidade espacial naturalmente não garante a solidão; mas é uma condição necessária" (Tuan 1983, p. 74).

Foi proposto que ficassem em silêncio, onde se sentissem bem e pudessem refletir sobre os acontecimentos dos últimos dias. Depois, deveriam escrever uma carta para si mesmos. Receberam todos duas folhas de papel sulfite reciclado: uma para poderem redigir e a outra para confeccionarem um envelope que deveriam endereçar adequadamente, além de lápis e canetas coloridas para os que quisessem desenhar. 
Esse é o momento de "compartilhar a inspiração", conforme sugere Cornell $(1995,1997)$ nos seus livros, ou de estar "refletindo", segundo a vertente de "educação ao ar livre", conforme já foi abordado. Dos 20 depoimentos que foram gravados, a atividade solo foi citada em 10 deles, portanto em 50\%, justificando-se, assim, algumas reflexões sobre ela, mesmo que para alguns parecesse de início, estranho ou desconfortável "ficar sozinho":

Cygnus: "Detesto ficar sozinha. Minha casa estava vazia e eu estava sozinha e isso me incomodou muito. Como vou fazer a atividade solo? Sentei em um lugar quietinho, me senti super bem, aprendi muito, vencendo vários bloqueios".

Indus: "O solo. Falei com a Sandra: como vou conseguir ficar duas horas comigo no solo? E consegui. Foi gostoso. Num espaço "besta" de duas horas, consegui, aconteceu. Foi uma coisa de evolução...duas Indus se encontraram na hora certa".

Auriga: "Em Itatinga a atividade mais difícil de fazer foi a atividade solo. Ali tive condição de responder uma pergunta que muitos fizeram: o que você tem?"

Apesar de uma estudante ter dificuldades em compreender qual era a proposta, que solo era ficar só, destaca-se seu depoimento:

Delphinus: "Quando li solo, achei que fosse uma atividade sobre solo mesmo (...) (voltado para geografia). Adorei. Foi bem acima da minha expectativa, até porque senti muito a evolução. $O$ encontro todo teve uma evolução para chegar hoje no solo. As atividades foram muito bem colocadas, encaixadas, umas após as outras".

Os outros estudantes também deram depoimentos que deixam clara a necessidade de uma atividade mais introspectiva, pois "é o momento de sedimentação da experiência. Dá um fechamento para o dia favorecendo a sensação de totalidade" (Mendonça, 2000, 145). Destaca-se que "privacidade e solidão são necessárias para uma reflexão perseverante e uma introspecção rigorosa, e através da compreensão do 
próprio eu para que se atinja a plena apreciação de outras pessoas" (Tuan, 1983, p. 74).

Nesse momento, as pessoas sentem-se livres, pois a atividade remete a um conhecimento interior, fazendo emergir emoções e subjetividades:

Phoenix: "O que foi extremamente positivo foi a trilha de surpresas e o solo, pois já valeram o encontro todo. As respostas que estou esperando ter de fora, neste solo, descobri que é dentro, é aqui dentro que tenho que procurar resposta, dependendo menos de um diálogo vindo de cima. Isso foi muito bom".

Cassiopeia: "Neste contexto o exercício solo foi um momento mágico. Muito obrigada a vocês, a Itatinga. A hora dele foi perfeita, tinha imaginado que ia ser legal, mas não tão legal como foi. Não que mudou minha vida, mas eu parei e pensei um monte de coisas, mesmo dentro da idéia de sair da minha vida rotineira; isso clareou muito, muito".

Columba: "A coisa tocou muito pelo lado pessoal, mesmo tendo trabalhado a cooperação, de grupo, o (lado) pessoal de cada um cresceu bastante. Neste solo agora, ficou muito claro, foi muito legal ter fechado com o solo, pois cada um veio crescendo/buscando durante o encontro todo".

Um estudante faz um resgate da sua infância, a partir das atividades do dia anterior, que se consolidam no solo: a "quadrilha" na festa surpresa (ele ficou muito emocionado ao final da dança), e "guardar caixão" que se refere a um jogo cooperativo:

Centaurus "O fato de dançar quadrilha e guardar caixão foi um trabalho psicodramático. Vieram à tona elementos da infância que há muito tempo estavam apagados da minha cabeça e vieram à tona ontem, e no momento solo pude trabalhar isso".

Destaca-se ainda a importância dessa atividade, principalmente, depois de estar quatro dias imerso em atividades realizadas no coletivo, pois “(...) precisamos de 
uma dimensão de pensamento que não se apresse em enquadrar a realidade em esquemas pré-fabricados; uma postura existencial que se ponha à escuta da vida e de seus sinais" (Unger, 2001, p. 138).

Esse momento solo tem, então, o poder de contribuir para uma síntese pessoal, de encontro consigo, de resgate de subjetividades, sentimentos e emoções que, nesse caso, se consolidaram numa carta que escreveram para si, representando também um "presente" e o "estar presente".

Deve-se destacar a importância de momentos como este - de diálogos com sua própria individualidade, de "arqueologia virtual do presente" como nos fala Santos (2000), de introspecção - no desenvolvimento de estudos do meio comprometidos com uma educação emancipatória, empoderadora, mobilizadora do sujeito em toda a sua subjetividade, como nos fala Paulo Freire, ao longo de toda a sua obra; Edgar Morin, ao descrever os sete saberes necessários à educação do futuro, e Jacques Delors, em seu relatório para a UNESCO sobre a Educação para o séc.XXI.

\subsubsection{Projetos de intervenção}

A proposta de se elaborar e realizar um projeto de intervenção estava explícita para os ingressantes, desde o início do curso, como um dos seus eixos articuladores. Os itens solicitados para compor o projeto foram: justificativa, objetivos, local, público alvo, atividades, estratégias, cronograma, avaliação, atividades realizadas, resultados obtidos.

Foram consideradas, para análise, apenas as versões finais entregues no término do curso. A pesquisadora utilizou 18 documentos de 22 estudantes, pois dois deles foram feitos em grupo. Os projetos analisados foram os dos seguintes estudantes: Crux e Fornax e, Auriga, Circinus e Cygnus, que fizeram o projeto em grupo. E ainda os de Apus; Capricornus; Carina; Cassiopeia; Centaurus; Cetus; Columba; Corona; Crater; Delphinus; Draco; Hercules; Horologium; Taurus; Phoenix; sendo que Hydra e Indus fizeram-no individualmente, apesar de que versaram sobre atividades em zoológicos.

Durante a análise dos projetos, desprezaram-se as referências ao termo "pertencer", quando não tinham o sentido tratado na pesquisa, como por exemplo, "a escola foi inaugurada no ano passado e pertence ao sistema das Escolas 
Associadas". Mesmo assim, em oito projetos de intervenção, ele foi citado explicitamente, isto é em 45\%, aproximadamente.

Columba, Carina e Taurus utilizaram os dois termos nos projetos: estudo do meio e pertencimento.

\subsubsection{Estudo do meio}

Em dois documentos analisados, houve menção a essa técnica, sob outras denominações - "aulas passeio" e "atividade em áreas verdes" - que deixaram dúvidas quanto a estarem ou não se referindo a estudos do meio, por não ficar explícita a metodologia ou proposta pedagógica envolvida. No entanto, em um terceiro projeto, sobre "turismo de aventura", de Phoenix, um dos objetivos propostos foi "apresentar novas ferramentas que auxiliem o trabalho do guia ou monitor como educador ambiental". Afirmou a estudante que estaria utilizando atividades na natureza para promover reflexões e conscientização dos guias de turismo de aventura; valorizandose, então, a sua finalidade educativa dentro da proposta.

Considerando-se a dificuldade em se quantificar, nos projetos de intervenção, a utilização de estudos do meio, contabilizaram-se apenas as citações explícitas, que apontaram que $45 \%$ incorporam essa técnica na sua proposta. No entanto, esse percentual poderia chegar a $80 \%$, se acatasse as propostas afins que surgiram, como por exemplo, de implantar um viveiro de mudas de espécies da Mata Atlântica e utilizálo para atividades de Educação Ambiental; ou de trabalhar a questão do lixo com a vizinhança de uma escola rural; ou mesmo as atividades em áreas verdes, entre outras.

No projeto apresentado em conjunto por Crux e Fornax, denominado "Educação Ambiental nas escolas", fez-se um diagnóstico detalhado da realidade de uma determinada comunidade escolar, na perspectiva de se aplicar alguns dos procedimentos adotados com resultados bastante positivos para toda a comunidade de uma outra escola, ambas de periferia do município de Piracicaba/SP.

O diagnóstico revelou que a criatividade e o prazer em aprender estavam completamente ausentes da sala de aula: havia dificuldade na aprendizagem e um alto índice de alunos não alfabetizados; não havia vínculo entre escola e comunidade, entre outros problemas. 
Para enfrentar esses e outros problemas, escolheram o tema transversal "meio ambiente", proposto nos PCN (1997), isto é, Educação Ambiental como norteadora para as ações pedagógicas. Pode-se afirmar que Crux e Fornax não fazem referência direta à terminologia "estudos do meio", e sim "aulas-passeio", no entanto, é possível considerá-las sinônimos pois no documento colocam que há necessidade de se "articular as experiências de vida dos alunos ao conhecimento sistematizado, de modo que possam perceber o mundo de forma integrada (...)".

Draco, ao propor o seu projeto de intervenção "Estudo do meio rural: uma abordagem pedagógica", surpreendeu com a similaridade, não só das vivências pedagógicas, mas também dos conteúdos teóricos vistos no curso, como será demonstrado a seguir.

Ele descreveu, com detalhes, um curso de aperfeiçoamento concebido e implementado para educadores de escolas rurais do ensino fundamental de Piracicaba/SP, no qual, depois, incorporaram-se educadoras e diretoras também da zona urbana do município. Realizou o curso com 10 encontros e carga horária total de 31 horas, incluindo um estudo do meio pela região com quatro horas de duração.

Entre os objetivos de um dos encontros, o do "estudo do meio rural", destacamse: "perceber como os participantes estão se sentindo; preparar e instrumentalizar as participantes para o reconhecimento do meio rural; demonstrar o potencial e a abrangência do estudo do entorno no contexto de processos educacionais; e perceber se as participantes gostaram ou não das atividades". A pesquisadora foi convidada a participar dessa saída, trazer contribuições e fazer um fechamento no encontro seguinte (Anexo $M)$.

Ao relatar esses dois encontros, Draco afirma que:

"Este encontro e o próximo remetem à Itatinga, onde pudemos experienciar várias possibilidades de atividades em ambientes naturais, dentre elas, o estudo do meio que também foi utilizado no curso para as professoras e diretoras. Pude perceber melhor as potencialidades da atividade como recurso de aprofundamento dos conteúdos escolares que buscam uma maior integração de alunos e professores com esses locais de estudo". 
Essa consonância com as propostas pedagógicas e filosóficas do curso de especialização, como em qualquer processo educacional, não foi unânime entre os estudantes. Parece que, para alguns, haveria necessidade de um tempo maior de maturidade, discussão e reflexão sobre alguns conteúdos, mas principalmente, sobre a sua práxis.

O projeto apresentado por Hydra, "O zoológico de São Paulo como instrumento de Educação Ambiental" traz o relato de duas intervenções realizadas no local, com crianças e adolescentes.

"O que pretendemos fazer é mostrar a essas crianças, de forma leve e divertida, que é gostoso conviver com a natureza e que podemos fazer isso em paz, de forma tranqüila e segura, sem precisarmos destruí-la ou temê-la".

Essa concepção é, de certa forma ingênua, pois contribui para criar no imaginário uma natureza como o paraíso perdido, a Arcádia, onde não há perigo, temores ou desconforto. Vale lembrar que "nem todas as culturas abraçam natureza, e paisagem com igual ardor, e as que as abraçam conhecem fases de maior ou menor entusiasmo" (Schama, 1996, p.25).

Uma outra estudante, Indus, que também fez seu projeto de intervenção no zoológico de São Paulo, vê a possibilidade de conexão com a natureza a partir de uma visita ao zoológico, com a seguinte referência:

"pois para que a visita seja efetiva, agradando realmente os visitantes para que possa ser desencadeado um processo de religação com a natureza como um todo, tendo como base 0 conhecimento, é importante apresentar as principais classes de animais".

A possibilidade de conexão apontada é questionável num local tão antropizado, sendo reafirmada num dos objetivos do projeto de Indus: "aproveitar o espaço do zoológico de São Paulo de forma lúdico-educativa (...) contextualizando estas informações no dia-a-dia do visitante, de forma leve e envolvente, e promovendo o processo de re-ligação entre o ser humano e mundo natural". 
Tuan (1983) considera que há dois tipos de espaço mítico que florescem na ausência de um conhecimento preciso: um é o de uma área imprecisa de conhecimento, ainda deficiente, envolvendo o empiricamente conhecido, uma extensão conceitual/imaginária a partir do espaço conhecido, visível, familiar e cotidiano. O outro, funciona como um elemento de visão do mundo ou cosmologia, na tentativa de as pessoas compreenderem o meio ambiente. $O$ autor afirma que as pessoas requerem do seu ambiente uma sensação de ordem, e ainda, de boas condições. $O$ zoológico parece preencher essas duas formas de espaço mítico, pois uma visita possibilita imaginar o ambiente natural de origem dos animais ali expostos, e, também, oferece uma forma de sistematização e compreensão do meio ambiente, representando, portanto, no espaço construído, essa relação harmoniosa.

Capricornus fez o seu projeto de intervenção para atividades em sala de aula e também fora dela; sendo que um dos objetivos específicos citados é "sensibilizar os alunos para a percepção do ambiente que o rodeia, trabalhar o conceito de ambiente e a inter-relação entre os diversos elementos, usando para isso os órgãos dos sentidos: audição, visão, olfato, tato, paladar".

Ela propôs 18 atividades para serem desenvolvidas ao longo do ano, entre elas, "observando o ambiente" e "zoológico e parque ecológico". Com relação à visita ao zoológico, comenta que os alunos "ouviram muitas regras" do monitor "que deu as explicações em frente de cada jaula. Houve muito barulho, muita conversa, pouco interesse e muita brincadeira na hora da explicação".

A imposição de regras rígidas de comportamento são muito comuns em visitas aos zoológicos, onde as crianças são obrigadas a andar em fila indiana ou todas de mãos dadas. Indus afirma que utilizou um apito para auxiliar as atividades no zoológico, e relata o seguinte:

"O uso de um apito para chamar a atenção das crianças (...) se mostrou extremamente negativo. O apito além de remeter a uma idéia de arbitrariedade "militar", ainda pode ter causado estresse aos animais devido ao seu som extremamente estridente".

As atividades desenvolvidas em zoológicos são muito comuns, tanto no cotidiano escolar, quanto também no familiar, como forma de lazer. Nesses exemplos percebe-se que a qualidade do contato com o ambiente recreativo tem continuidade 
com o da sala de aula, pois é seguido de regras de conduta que limitam. Assim, a oportunidade, que seria também de um despertar para o conhecimento, é tolhida e até equivocada, quando se considera possível, a partir de uma visita nessas circunstâncias, uma re-ligação ao mundo "natural" .

Corona comenta em seu projeto que um dos desafios da escola é o de "proporcionar uma educação que leve em conta os fatos da realidade, tanto no que se refere à realidade global, quanto no que se refere à realidade local, promovendo a reflexão". Na introdução, ela diz que:

"Segundo Hutchison (2000), vivemos, do ponto de vista cultural, uma tensão entre as visões tecnozóica, segundo a qual a engenhosidade humana e as inovações tecnológicas seriam capazes de solucionar todos os problemas humanos e ambientais, e ecozóica, segundo a qual é necessário o reengajamento de nossa civilização com a comunidade da Terra e com o mundo natural, valorizando-se o bem-estar não apenas do ser-humano, mas de todo o planeta".

A seguir, ela insere a problemática no cotidiano escolar que vem trabalhando os conteúdos de maneira fragmentada e dissociada do cotidiano.

"A escola acaba, na maioria das vezes, contribuindo para a manutenção dos sistemas econômico, social, político e cultural vigentes, sem questioná-los quanto à sua inviabilidade e, o que é pior, sem convidar os estudantes a imaginarem ou pesquisarem soluções para os problemas ou até mesmo, uma nova interação entre sociedade, economia e meio ambiente".

E é convidando os estudantes a imaginarem e pesquisarem soluções para os problemas (Ott, 1989), que faz uma proposta que pode ser considerada como um estudo do meio parcial (Nidelcoff, 1979) e urbano, pois programou atividades e estudos de meio com a finalidade de diagnosticar os problemas ambientais no espaço escolar onde atua, pressupondo ainda que a escola é um reflexo do que ocorre no ambiente urbano, podendo-se discutir e envolver a comunidade escolar em mobilizações ambientais. 
Destacando-se um dos objetivos gerais apresentados por Corona, no qual pretende desenvolver a sensibilidade para a problemática ambiental e, em um dos objetivos específicos, de reconhecer o "meio ambiente urbano a fim de que se construa uma percepção mais atenta da realidade que circunda a escola"; ela expressa a intenção de promover atitudes emancipatórias através da percepção e compreensão do entorno.

Esse leque de discussões permite apresentar a diversidade com que os estudos do meio podem ser compreendidos, planejados e implementados - desde o que reproduz o ensino tradicional até o mais complexo - retomando, de certa forma, a realidade do ensino no Brasil. Portanto, compreende-se que depende do educador perceber as possibilidades da proposta, aproveitando essas oportunidades de convivência para desatar as amarras impostas pelo rigor da disciplina escolar e dos conteúdos. Nesse sentido, a necessidade de formar formadores, fica evidente.

\subsubsection{Pertencimento}

Entre os projetos de intervenção que explicitam o conceito de pertencimento (45\% deles), é interessante o relato de Hydra, após a visita ao zoológico, pois a estudante, num primeiro momento, pressupõe que a mudança de atitudes é inerente à conscientização:

"Pudemos perceber que, durante o percurso, a maior parte das crianças e dos adolescentes não jogaram lixo no chão e nem nos recintos dos animais, muitas vezes até pegaram o lixo que já estava no chão e jogaram nas lixeiras. Pensamos tê-los sensibilizado e, com isso, causado uma mudança de atitude".

Em seguida, porém, ao final da visita ao zôo, relata a atitude dos adolescentes e faz a seguinte reflexão:

“(..) mas com os adolescentes pudemos constatar que os mesmos ao retornarem à escola, chutaram o lixo que estava nos sacos na rua em frente. Durante o percurso no ônibus, não sujaram o mesmo, o que nos fez pensar e achar que só tinham essa atitude no passeio e que não conseguimos mudar a sua 
atitude em outros ambientes. Seria porque eles não sentem que a escola é deles, ou seja, não se sentem pertencentes à escola?".

Centaurus afirma que o intuito maior de seu projeto é "desencadear um processo de construção de uma comunidade sustentável, erguida por indivíduos cientes de seu papel de atores na mudança desejada". Ele traz o seguinte objetivo geral:

"Contribuir para despertar em professores e alunos a capacidade de empreendimento e mobilização social; assim como a autoestima de ambos - professores e alunos -, e o sentimento de pertencimento de todos eles à região em que estão inseridos, sem perder a perspectiva de busca de uma sobrevivência satisfatória e sustentável".

Em seu projeto, Columba afirma que a comunidade na qual irá trabalhar não tem despertado o sentido de pertencimento em relação à escola, ao bairro, etc. Cetus apresenta um trecho de Diegues $(1999)^{52}$ sobre a questão da identidade e pertencimento:

"Há uma reduzida divisão técnica e social do trabalho, sobressaindo o artesanal, cujo produtor (e sua família) domina o processo de trabalho até o produto final; fraco poder político, que em geral reside com os grupos de poder dos centros urbanos; e auto-identificação ou identificação pelos outros de se pertencer a uma cultura distinta das outras".

Apesar de ser possível afirmar que esse conceito está presente em parte dos projetos de intervenção, a complexidade da problemática que o envolve, bem como uma discussão que busque o enfrentamento dessas questões ainda requerem aprofundamentos.

52 DIEGUES, A. C.; NOGARA, P. J. O nosso lugar virou parque: estudo socioambiental do Saco do Mamanguá, Parati, Rio de Janeiro. NUPAUB/USP. São Paulo, 1999. 165p. 


\subsubsection{Minicurso}

Considerou-se para análise as propostas de minicursos em sua versão final, desprezando-se, portanto, as intermediárias que foram entregues. Foi solicitado para a apresentação (oral e escrita) da proposta: nome do minicurso, duração, período (dia/mês), público-alvo, número de participantes, justificativas, objetivos educacionais, metodologia, metas, conteúdos, cronograma, orçamento, materiais, forma de avaliação, sustentabilidade do curso, bibliografia, currículo do proponente.

Do total de 23 estudantes que se apresentaram no último encontro, a proposta de Gemini não foi localizada, assim utilizou-se um total de 22: 20 eletrônicas e 2 entregues em papel. Buscaram-se nos documentos as citações diretas ou implícitas à utilização de estudos do meio e ao conceito de pertencimento.

\subsubsection{Estudo do meio}

Desse total, pode-se afirmar que, aproximadamente $32 \%$ mencionam a intenção de utilizar estudos do meio, fazendo uso de alguma área em zona rural, zoológico ou área natural protegida.

Na proposta de Centaurus, há valorização do contato com o meio rural, explícita nos objetivos: "reconhecer a importância da produção rural para a sociedade; avaliar a relevância da preservação e conservação do ambiente, como forma de se ter qualidade de vida; construir formas harmônicas de relacionamento com a natureza".

Não há referência direta ao termo 'estudo do meio', no entanto, sugere alguns procedimentos considerados referência direta a essa técnica:

"Observar o meio em que vive e registrar suas características por meio de desenhos, listas e produções de textos coletivos; comparar o meio natural e o meio construído a partir de passeios, visitas e excursões; construir maquetes coletivas para caracterizar o meio natural e o meio construído, representando em ambos, os componentes naturais: ar, água, solo, seres vivos, luz e calor".

É nítida a importância que Centaurus atribui aos estudos do meio, como uma ponte para aprendizagem entre o modo de vida urbano e o rural, através da observação, documentação, pesquisa, etc. 
Indus apresenta uma proposta de valorizar a natureza por meio da monitoria ambiental: "o uso de áreas verdes urbanas", apontando em um objetivo educacional a intenção de "contribuir para o processo de sensibilização dos participantes, a fim de que eles possam vir a se tornar monitores ambientais que valorizem a natureza, de forma que sua função seja mais do que a de mero fornecedor de informações".

Ela prevê saídas para zoológico e jardim botânico e, na metodologia, cita a utilização de "jogos, dinâmicas e reflexões que proporcionem aos participantes um contato bastante dialógico com os temas abordados/levantados".

Já a proposta de Draco sugere o tema de plantas medicinais, indicando a utilização de espaços abertos ou aulas práticas, para um contato direto nas atividades mencionadas: "trilhas e visitas de estudo; classificação e utilização de plantas medicinais; cultivo, colheita e elaboração de produtos a partir de plantas medicinais".

Delphinus apresenta na sua proposta a utilização do "potencial educacional de Áreas Naturais Protegidas". Na metodologia, descreve alguns procedimentos considerados necessários para atividades desse tipo:

“(...) o monitor do curso visitará uma área que deverá ser utilizada para a prática do curso (...), levantar seu potencial educacional e elaborar as atividades que serão desenvolvidas; diagnóstico do que os alunos entendem por uma atividade de Educação Ambiental, qual a importância que eles vêem nessas atividades e se já desenvolveram alguma atividade semelhante; qual a sensação que se tem estando ali; vivenciarão atividades para o desenvolvimento da percepção da natureza, seguindo a metodologia de Joseph Cornell".

Conforme considerou-se na revisão de literatura sobre estudos do meio, a visita antecipada ao local da visita é bastante apropriada; bem como a realização de um diagnóstico prévio com os estudantes, a promoção de atividades de sensibilização e socialização das percepções são importantes e adequadas para a Educação Ambiental que busca desenvolver "atividades que aproximam o homem da natureza", como afirma Delphinus.

Bastante próxima à proposta de Delphinus, Hercules dimensiona seu minicurso para unidades de conservação, expressa através do objetivo de: 
"Contribuir para que os envolvidos possam desenvolver habilidades e construir ou ampliar, de forma crítica e reflexiva, conceitos básicos sobre Educação Ambiental; observando nas unidades de conservação potencialidades a serem exploradas com finalidades de ensino-aprendizagem em Educação Ambiental".

A proposta apresenta influência não só dos estudos do meio, mas também da disciplina "Re-conhecendo o meio ambiente", como pode-se verificar em três conteúdos citados: "teoria da aprendizagem seqüencial - (Cornell, 1995, 1997); jogos cooperativos (Brotto, 1999); educação ao ar livre - "Ropes Course'”".

Coloca como requisito básico a presença de "recursos naturais: bosque ou mata com vegetação exuberante e trilhas" e, sugere alguns locais para a realização do minicurso: "Parque Estadual de Campos do Jordão, Horto Florestal de Itatinga, Fazenda Vale Encantado (VUNA) em Atibaia, entre outros". O que demonstra uma atração desse estudante pelo local onde foi realizada a disciplina, indicando um sentimento de topofilia (Tuan, 1980) e identidade (Unger, 2001).

"A ameaça à vida do rio e do povo e a urgência de uma resposta não provocam uma atitude reativa ou meramente pragmática e instrumental: o modo de realizar o objetivo predomina, e seu traço essencial é a sociabilidade que se tece no próprio caminhar. Nessa sociabilidade do caminhar, a educação se faz como recordação de uma sensibilidade, um modo de experienciar a vida, uma identidade" (Unger, 2001, p.107).

Através da leitura dos segmentos das propostas de minicurso apontadas, podese perceber que há uma diversidade entre elas. Alguns estudantes detalham as propostas, orientados por autores que foram vistos na disciplina e outros apenas indicam um espaço ou lugar para realização de atividades.

\subsubsection{Pertencimento}

Dos minicursos analisados, o conceito foi citado explicitamente em duas propostas, destacando-se a profundidade com que foi abordado, inclusive por outros autores. 
A partir do título sintético de Auriga, "Con-vivendo", parece haver um convite a uma parada e reflexão, pois indica no subtítulo a necessidade de potencializar "reflexões e ações sobre o cotidiano, explorando habilidades através da comunicação e do uso de diferentes linguagens". Em dois objetivos gerais, esse "convite" parece se consolidar, pois propõe "refletir sobre as interdependências do meio natural com o social e as formas de desenvolvimento" e "provocar a construção de um novo olhar que possibilite ações mais conscientes e transformadoras, partindo de um repensar sobre o eu".

Nos objetivos, Auriga sugere "propiciar uma leitura sistêmica da realidade" e provoca para que o indivíduo reflita sobre a importância da formação diante da informação "nos processos de codificação e decodificação da realidade", influenciando a "construção histórico-cultural de uma comunidade". Propõe, ainda, "provocar reflexões que contribuam para a construção de atitudes que reflitam os sentimentos de "cuidado" e pertencimento".

Em uma das metas apresentadas, a de "contribuir para a transformação pessoal e social, através de um processo de reflexão para a construção de ações éticas e conscientes", parece haver coerência com as propostas na introdução do Tratado (1992), mas, principalmente, no que consta no plano de ação número 4 deste documento, de se trabalhar os seus princípios "a partir das realidades locais, estabelecendo as devidas conexões com a realidade planetária, objetivando a conscientização para a transformação".

Propõe uma atividade em grupo para:

"elencar possíveis estratégias de ação que promovam nos grupos sociais ao qual você está inserido, o sentido de pertencimento e de cuidado, tendo como ponto de reflexão o conceito de Leonardo Boff: 'o cuidado somente surge quando a existência de alguém tem importância para mim. Passo então a dedicar-me a ele; disponho-me a participar do seu destino, de suas buscas, de seus sofrimentos e de seus sucessos, enfim, de sua vida"'.

O conjunto de atividades individuais e coletivas apresentado, que explora as linguagens corporal, lúdica e artística nos processos de comunicação, é distribuído em 
momentos diversificados e expressado por imagem, mímica, escultura viva, cenário construído com argila e música.

Com relação à utilização de diferentes linguagens, Mendonça (2003) afirma que é preciso pensar em um sistema que não fragmente o saber, que seja diferente do que existe nas escolas, "mesmo diante do recente esforço interdisciplinar, de interdependência de conhecimentos". A temática ambiental, normalmente tratada numa perspectiva unidisciplinar, terá de ser tratada de outra forma. "A decodificação só se dará a partir de uma visão de educação na qual os protagonistas sejam pessoas que falem em uma outra linguagem" (Mendonça, 2003,p. 18).

Assim, essa proposta ganha também uma dimensão de enraizamento que, segundo Unger (2001), numa dimensão profunda, explora:

"O saber apenas abstrato não é estruturante da vivência social. Mesmo que estruturasse essa vivência em algum nível, ficaria desenraizado, perderia sua autenticidade. A experiência de estar no mundo, de morar, é a experiência do entrar em relação com a alteridade, com o sagrado; é a relação com a terra, com os outros, consigo, com o todo. Na medida em que traz em sua própria dinâmica a necessidade de ser comunicado, remete para a comunidade, para a socialização, para a integração das crianças, das mulheres, dos outros homens na comunidade" (Unger, 2001, p. 140).

O saber da experiência proposto por Unger (2001) e também por Bondía (2001) enraíza também, porque singulariza e promove identidade através de um olhar para a complexidade.

A outra proposta de minicurso de Corona, unindo Astronomia e Educação Ambiental, inicia com frases de Morin (2000) de "ensinar a identidade terrena"; e, com o artigo 8 da carta da transdisciplinaridade:

"A dignidade do ser humano é também de ordem cósmica e planetária. O surgimento do ser humano sobre a Terra é uma das etapas da história do Universo. O reconhecimento da Terra como pátria é um dos imperativos da transdisciplinaridade. Todo ser humano tem direito a uma nacionalidade, mas, a título de 
habitante da Terra, é ao mesmo tempo um ser transnacional. O reconhecimento pelo direito internacional de um pertencer duplo a uma nação e à Terra - constitui uma das metas da pesquisa transdisciplinar" (Freitas; Morin; Nicolescu ,1994).

Perante a aparente distância que há entre esses olhares: Astronomia e pertencimento, destaca-se uma reflexão de Unger (2001) sobre a influência do cálculo sobre o comportamento humano:

"O cálculo, que domina o modo de ser do homem planetário, não designa simplesmente a prática do saber matemático, mas "um modo de comportamento" que determina todo tipo de ação e atitude desse homem. Segundo Heidegger, sua exacerbação é a atitude que só reconhece como real a ação prevista, organizada, planificada. O cálculo enquanto tal, se opõe a todo movimento espontâneo daquilo que cresce a partir de si mesmo, daquilo que se move a partir de seu conhecimento intrínseco" (Unger, 2001, p. 127).

A Astronomia, conforme Corona sugere, é considerada uma ciência exata e abstrata; no entanto, pode ser um excelente exemplo, também com outras ciências nas quais o educador contribui, trazendo um olhar cuidadoso "com os entes e as coisas" sobre esses conteúdos considerados mais "duros", pois, geralmente, são envolvidos apenas de cálculos e abstrações distantes da realidade.

Essa aproximação entre um campo conceituado como hermético na atualidade, a Astronomia é, no entanto, a ciência considerada com a mais antiga, com registros em pinturas rupestres que datam de 50 mil anos, merece destaque pela pertinência dos objetivos apresentados na proposta do minicurso:

“(...) mostrar como a Astronomia vem alterando a visão do ser humano sobre sua posição no universo; apresentar a Astronomia como eixo transdisciplinar que auxilia na construção da consciência planetária e na percepção do ser humano como ser de identidade transnacional e cósmica, contribuindo para 0 sentimento de identidade terrena; demonstrar as contribuições das missões interplanetárias e da cosmologia para o 
reconhecimento da Terra como mundo vivo, como planeta singular e precioso em meio a uma infinidade de mundos estéreis; demonstrar como a planetologia comparada vem ajudando a humanidade a compreender a fragilidade de nosso planeta, sua ecologia e os perigos que o atual modelo de produção impõe à perpetuação da Terra e da humanidade".

Essa proposta faz emergir algumas reflexões, como por exemplo, a de confirmar a necessidade do enraizamento físico ou "espiritual" para o ser humano, mas que contribua para a compreensão da condição terrena, da fragilidade do modo de ser (contemporâneo) da humanidade neste planeta. O que merece ser destacado na proposta de Corona, e que ela deixa explícito, é que ao "humanizar ou traduzir" a Astronomia para leigos, o faz optando por valores e reflexões que, provavelmente, estiveram ou estão presentes também na origem do conhecimento científico, agregando então o "conhecimento intrínseco" expresso por Unger (2001).

O que chama a atenção nessas duas propostas é a compreensão do conceito de pertencimento que é mostrado com profundidade nas abordagens, mas, principalmente, a oportunidade que Auriga e Corona captam e trazem como exemplos de formas diferenciadas de realização para repensar a inserção do ser humano na problemática socioambiental, no enraizamento que vai, tanto na busca de soluções, quanto no resgate da sua identidade terrena.

\subsubsection{Relatório descritivo-analítico}

Foram localizados, lidos e analisados 20 relatórios descritivos-analíticos, produzidos ao final do curso, com as lembranças e anotações do ocorrido durante sua realização. Portanto, seis meses após a disciplina e 10 meses após o início do curso, como um dos produtos de finalização. Nas leituras, buscaram-se citações ao estudo do meio e pertencimento; no entanto, chamou a atenção as impressões sobre o curso e também sobre uma atividade específica que ocorreu no primeiro encontro: "o labirinto da contemporaneidade", interpretada como um estudo do meio "in door", contribuindo então, para a análise desses itens. 


\subsubsection{Estudo do meio}

A viagem a Itatinga foi citada em $55 \%$ dos relatórios apresentados, mesmo entre duas estudantes que não participaram da disciplina, houve manifestações com uma impressão positiva.

Apus: "Infelizmente, não pude estar em Itatinga. Sinto pelos comentários, que perdi um dos momentos de maior vivência e interação entre o grupo".

O depoimento de Apus comprova a repercussão positiva que houve entre os estudantes, após a viagem. Entre os relatórios dos que lá estiveram, podem ser depreendidos dois enfoques relacionados às contribuições do estudo do meio: um pedagógico e o outro para coesão ou sinergia do grupo.

Circinus: "O encontro em Itatinga veio no tempo certo (...). O grupo curtiu tanto aqueles momentos, participou tão intensamente de cada atividade, se entregou de alma àquilo que estava sendo proposto, saboreou tanto cada experiência, agiu com tamanha união, que, às vezes, eu tinha a sensação de fazer parte de um grande organismo vivo funcionando em equilíbrio (...). Comecei a pensar na natureza não só por sua importância na manutenção da vida ou como fonte de recursos, passei a relacionar o bem estar físico e psicológico do homem, através do contato com o meio natural. Ficou nítido o efeito benéfico que o contato em Itatinga teve sobre mim".

Hercules: "O ponto alto de fermentação do espírito de cooperação no grupo teve no encontro de Itatinga a sua melhor oficina".

Indus: "Itatinga tinha sido, na minha opinião, o máximo em questão de encontros presenciais. Todas as atividades envolvidas, inclusive o exercício solo, foram organizadas de uma forma tão coerente (até hoje tenho minhas dúvidas se isso foi intencional ou não), que me fez pensar em "bruxaria" (risos). De fato, o planejamento foi feito de forma tão minuciosa e carinhosa que o mais provável é que a Sandra tenha tido mesmo algum tipo de "luz" na hora de elaborar". 
Cassiopeia: "A idéia de aproveitar o meio como recurso pedagógico - conhecê-lo, diagnosticar as suas possibilidades e, aplicar conteúdos através do trabalho de campo, ou através do próprio diagnóstico - isto tudo foi novo... Até então, eu nunca tinha trabalhado com isso, com a idéia do trabalho fora de classe (...). $\mathrm{Na}$ verdade foi mais do que isso, foi um roteiro para a utilização dos ambientes (sejam naturais ou artificiais, ou ainda realidades sociais...), como ferramentas. E foi importante".

Draco: "Em Itatinga pudemos experienciar várias possibilidades de atividades em ambientes naturais, dentre elas, o estudo do meio (...). Pude perceber melhor as potencialidades dessa atividade como recurso de aprofundamento dos conteúdos escolares que busca uma maior integração de alunos e professores com esses locais de estudo".

Delphinus: "Este foi o que eu realmente esperava ansiosa, ele contribuiu demais (...) junto às escolas com que estou envolvida. Primeiramente foi nele que consegui, de fato, interagir com meus colegas de curso e nele pude perceber cada um deles, notando que todos de alguma forma eram pessoas interessantes de se conhecer e que havia algo fundamental a contribuir para 0 desenvolvimento do grupo. O que me ajudou muito a superar minhas dificuldades em conviver com os diferentes, como devemos saber em uma democracia.

Nesse último relato, de Delphinus, os dois enfoques estão explicitados, tanto as contribuições dos estudos do meio para se trabalhar os conteúdos, quanto para as relações interpessoais e até intrapessoais, pois ela afirma que a atividade contribuiu para que superasse dificuldades de conviver com o diferente.

Pelo que dizem Circinus e Hercules, não há dúvidas quanto às contribuições para a sinergia do grupo de estudantes.

Como que respondendo à dúvida de Indus sobre o fato de ter sido intencional a seqüência de atividades bem como todo o planejamento, cabe dizer que foi sim exaustivamente planejado: cada detalhe, cada trecho percorrido, a duração das 
atividades, os locais da realização, o período do dia, mas, principalmente, o cuidado com a seqüência visando contribuir com o envolvimento do grupo. Talvez esteja nesse ponto uma explicação para que a utilização de estudos do meio seja pouco freqüente no cotidiano escolar, pois exige tempo, envolvimento e dedicação do educador, além das atividades rotineiras de sala de aula.

\subsubsection{Pertencimento}

Houve citação direta ao termo pertencimento em 20\% dos relatórios; isto é, cinco estudantes fizeram reflexões sobre o termo, mas como se ele ainda estivesse "fermentando", como se a sua compreensão estivesse sendo elaborada internamente. Apesar de não se ter quantificado nessa pesquisa o número de vezes que os termos foram citados, chamou a atenção o fato de que, entre esses depoimentos, a palavra pertencimento ou pertencente foi citada, em média, mais de duas vezes por estudante, podendo ser um indicativo desse processo de "digestão". Uma estudante destacou-a, inclusive, com negrito.

Carina: "E para manter esse pessoal animado e participando? Pertencimento! Não conhecia essa palavra (...). Mas como fazer a pessoa se sentir pertencente? As resoluções devem partir do grupo e não serem impostas. Mas como as pessoas vão se sentir pertencentes se não partem delas as decisões?".

Circinus: “(...) a sensibilização, no entanto, não ocorre se não há sentimento de pertencimento, de que o ser humano faz parte da Terra e que interage com o seu ambiente, que é dele e vice-versa. Me questiono muito a esse respeito. Será que nós, como futuros educadores, temos vivo esse sentimento? Será que nossas atitudes cotidianas refletem esse comprometimento? Ou ainda muito do que sabemos é apenas retórica para nós? Aqui, em Canaã, pude perceber total falta de sentimento de pertencimento e todas as conseqüências desastrosas com as quais isso contribui, como desmatamentos, poluição de águas, solo, lixo, associações extremamente fracas, dependência total de um governo corrupto e manipulador, incentivo à prostituição, etc". 
Crater: "Durante o curso, senti que, para participar ativamente, o meu sentimento de pertencimento ao local (nosso curso), ao planeta e à humanidade (nosso sonho), não eram o bastante. Foi como o Marcos colocou: o sentimento de pertencimento é apenas uma das dimensões da participação (...), compreendi que a participação só poderia ocorrer a partir do sentimento de pertencimento à causa ou ao local em questão e que, com isso, estaria garantida a motivação para a mobilização em direção a determinado objetivo".

Delphinus: "Tudo isso confirma para mim que a sensibilização quanto ao pertencimento é o ponto de partida para esse processo, o que aplico mais tarde em meu projeto de intervenção quando uso as metodologias de Cornell para sensibilizar e utilizo o rio Itaúnas para simbolizar a ligação entre a região visitada e a região da moradia dos visitantes".

Entende-se que duas coisas merecem ser destacadas nesse conjunto de depoimentos: a primeira é a reflexão que as estudantes fazem, relacionando a sua prática ao pertencimento, isto é, fica nítido que foram para o campo, vivenciaram uma situação, e, ao refletirem sobre ela, na práxis, a questão do pertencimento ou da sua ausência emerge. $E$ a segunda é o fato de confirmarem, não apenas neste técnica mas também em outras, que o conceito surgiu e foi discutido a partir do curso, em sala de aula e das atividades propostas.

\subsubsection{O labirinto}

A montagem da atividade - o labirinto da contemporaneidade - e a sua realização já foram discutidas anteriormente; no entanto, o que se pretende destacar agora é o impacto causado pela proposta naquela oportunidade, pois 10 meses depois de realizada, ela foi citada em $60 \%$ dos relatórios descritivos. É possível fazer algumas inferências para explicar esse percentual, lembrando-se de que o curso ofereceu muitas outras atividades lúdicas, porém, essa foi a primeira (era um labirinto dentro de outro labirinto) e foi certamente a de maior impacto. 
Os relatos expressam, em minoria, desconforto/confusão ou uma sensação de surpresa e prazer, na maior parte deles.

Horologium: "O 'Labirinto' foi um momento de muita angústia e, ao mesmo tempo, o que ainda não havia percebido: tratar a questão da realidade atual, da contemporaneidade, e mostrar que podemos ter esperança, caminhos; senti meus pés no chão, ouvi sons agradáveis,vi um caminho, sem precisar estar de olhos abertos; preciso educar meus sentidos".

Capricornus: "depois veio o labirinto, muito assustador, como se estivesse tentando me acordar para o mundo, perceber a realidade, me deu medo, tristeza, sufocamento, sensações confusas. Foi bastante constrangedor!".

Cygnus: "No labirinto fiquei perdida com tanta informação, curiosa com os textos enormes que não consegui ler tudo, me emocionaram as fotos do Sebastião Salgado e fico sensibilizada com tantas pessoas com fome e sem conforto, o grandioso mundo da internet, (...) o pântano estava escuro e feio, com a psicóloga fiquei tímida, mas foi muito legal, na cozinha me senti em casa e acolhida, comi até um pedaço do pão, adorei a parte de vendar os olhos, trabalhar a percepção com diferentes formas nos grãos, sentindo a água, areia no chão, as cordas, etc.

Auriga: "A proposta do labirinto foi para mim, uma experiência fabulosa, caminhei por ele como educadora e educanda. Percebia que sua construção fora feita com muito cuidado e carinho, uma riqueza de detalhes que tornou a minha recepção agradabilíssima. Me senti realmente acolhida".

Crater: "Labirinto: achei o máximo! Uma super produção mas ficava o tempo todo me questionando o que aquilo queria dizer, qual era a conexão com Educação Ambiental e formação de educadores?" 
Como se observa nesse trechos, as colocações, via de regra, trazem percepções tanto sobre si mesmo quanto de uma situação externa. Esse jogo "interno/externo" tem grande sintonia com a proposta do curso, de ser "democrático circular", como foi concebida por Taurus durante o curso, ilustrada pelo labirinto e vivenciada por todos. Em apenas uma frase, "senti meus pés no chão", Horologium consegue resgatar um sentido praticamente ancestral do labirinto, de percorrer um caminho intuitivo, de seguir por ele através dos pés e, a partir do contato com o solo, atingir um outro nível de consciência, de diálogo interno; como buscam os visitantes da catedral de Chartres, quando o percorrem e, é ilustrado por este belo trecho de Unger:

"E, andando desta maneira, com o olhar voltado para o solo, vejo os nossos pés que caminham, dezenas, às vezes centenas de pés (...). Pés que levantam poeira em seu caminhar peregrino e que, neste momento, parecem simbolizar o caminhar de todo o povo nordestino, do povo brasileiro, do povo latino-americano, e o caminhar do próprio ser humano que, mesmo quando caminha só, inscreve seus passos no caminho de todos, que é o caminho do viver" (Unger, 2001, p. 65).

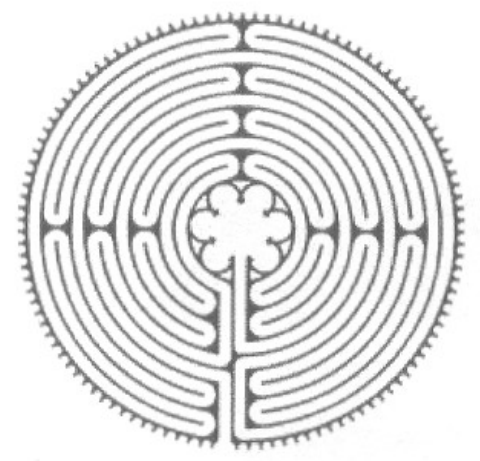

Figura 14 - Labirinto de Chartres

O caminho do labirinto - e que o conceito de pertencimento recende - é o de viver, do ser humano tornar-se no presente, o presente que pode ser. 


\subsubsection{O curso}

Surgiu a questão dos conflitos em relação à proposta inovadora do curso, em pelo menos $50 \%$ dos relatórios. Nesses documentos, a presença da construção e consolidação da comunidade de aprendizagem também foi marcante.

Taurus: "Problemas também aconteciam, tanto entre colegas como também entre os coordenadores, porém, a competência demonstrada pela coordenação do curso se revelou tanto na ordem da condução didático-pedagógica como na administração dos conflitos".

Corona: “ (...) não posso encerrar esse relatório sem mencionar a construção da comunidade de aprendizagem. Mesmo em meio a tantas angústias, creio que o último encontro foi uma demonstração de que nosso grupo alcançou, sem sombra de dúvidas, esses princípios e que, certamente, desenvolvemos nossa autonomia. Isso ficou bem claro quando, em nossa última reunião, discutimos o que o educador ambiental significa para nós e o que acreditamos serem os valores mais importantes da Educação Ambiental. E aí foi demais, porque construímos nossa identidade como grupo. E acredito que, a exemplo do próprio ser humano, somos e fazemos parte, como grupo, de um projeto infinito".

Apus: "Mas hoje posso dizer que as incertezas durante o curso me proporcionaram crescimento pessoal e profissional, talvez até mais pessoal. É impossível transcrever para esse papel a mudança do meu olhar sobre as pessoas, as relações e hábitos humanos".

No decorrer do curso as incertezas eram trazidas e discutidas no coletivo, como oportunidades de aprendizagem. Sendo assim, discutiu-se também a questão do conflito dentro do próprio conflito, em várias situações, inclusive em uma disciplina específica sobre o tema. Nesses depoimentos, pode-se perceber a compreensão que 
eles tiveram de que o conflito é inerente ao crescimento de um grupo, seja ele participativo ou em busca de emancipação.

Sobre isso, há um trecho do relatório de Carina bastante elucidativo:

"Acho que o conflito é uma oportunidade de crescimento. Pelo menos as pessoas reagem, comparecem, brigam, acontecem. Gostaria muito de aprender como trabalhar conflitos (...). Os conflitos fazem as pessoas pensarem. Como criticar, responder, debater sem pensar no caso? As audiências públicas podem ser muitas vezes frustrantes, mas mobilizam. É a verdadeira democracia. São os conflitos se cruzando e procurando a saída. É uma verdadeira aula de Educação Ambiental".

A construção da comunidade de aprendizagem esteve presente na maioria dos depoimentos:

Hercules: “(...) a construção de uma comunidade de aprendizagem seria necessária para fomentar os objetivos políticos e pedagógicos do curso de especialização. Sendo assim, por orientação e organização da coordenação do curso, a dinâmica empreendida desde o início foi muito acertada (...) É certo que, já no primeiro encontro, os processos desenvolvidos contribuíram decisivamente para integralizarem os atores do curso numa comunidade de aprendizagem. De forma que estava denunciado nesse momento o processo pedagógico alternativo pelo qual o curso transcorreria".

Horologium: "No início, não ficou muito claro e a idéia de grupo que o curso propunha; só depois entendi que era um grupo de aprendizagem".

Apus: "Acredito muito na comunidade de aprendizagem e no grande papel que todos os membros têm dentro dela (...) Saber ouvir e crescer com críticas, ah! Isso sem dúvida eu afirmo que o curso me ensinou, a importância de ouvir".

Draco: "Pudemos discutir um pouco mais sobre a importância da evolução do nosso grupo no sentido da construção de uma 
comunidade de aprendizagem em que todos aprendem, ensinam, trocam, têm responsabilidades e crescem juntos".

A proposta pedagógica do curso foi concebida e implementada, de forma que, através do diálogo e da explicitação de que a construção da comunidade de aprendizagem ocorreu a partir da disposição (do corpo docente e discente) em empreender e aprender por esse caminho. Foi um desafio constante trabalhar na incerteza, ou, como nos diz Morin, trazendo uma mensagem de Eurípedes, "de estarmos prontos para o inesperado" (Morin, 2000, p.79).

Morin (2000), no cap. V, "Enfrentar as incertezas", afirma ainda que a história avança através de inovações e criações internas, mas também de acontecimentos ou acidentes externos. Esse processo de mudança e transformação interna ocorre muitas vezes como "desvios" em relação à normalidade, que em condições favoráveis se proliferam, "produzindo uma nova normalidade". Porém, isso se dá através de organizações e desorganizações; isto é, de ordem e desordem dessa organização, de rearranjos como num estado de entropia.

Assumir o que ele propõe para enfrentar as incertezas: do real/realidade, do conhecimento/dogmas, e da ecologia da ação através da complexidade intrínseca a elas, foi a mola propulsora do curso.

\subsubsection{Entrevista semi-estruturada}

Através das respostas às perguntas iniciais da entrevista semi-estruturada (Anexo I), pretendia-se fazer um levantamento das atividades profissionais (atuais e/ou futuras) dos egressos, se estavam relacionadas à Educação Ambiental. Além disso, buscou-se verificar quais deles estariam realizando estudos do meio e as compreensões que tinham a respeito de diversos conceitos.

Dentre os 18 entrevistados, 11 afirmaram estar realizando atividades como educador ambiental, ao responderem a $1^{\text {a }}$ questão. São eles: Auriga; Cassiopeia; Cetus; Columba; Corona; Crux; Delphinus; Draco; Hercules; Indus; Phoenix. No entanto, não se pode afirmar que esses onze egressos passaram a praticar tais atividades - de educador ambiental - somente a partir do curso, apesar de ficar explícita, em algumas falas, a sua influência. 


\subsubsection{Estudo do meio}

Dentre os 11 , oito deles, portanto, aproximadamente $73 \%$, afirmaram utilizar atividades relacionadas a estudos do meio, como por exemplo, realizar vivências que envolvessem os sentidos e a percepção do entorno, como por exemplo:

Auriga: "A gente usa um pouco das propostas do Cornell e o princípio de cooperação; trabalha com vivência, com dinâmica e com leitura dos sentidos, o que se vê, o que se sente, o tato, o olfato, o paladar".

Cetus: "As atividades do final de semana são muito espelhadas em algumas dinâmicas que a gente fez durante o curso e em outras que o pessoal conhecia. Toda a atividade é o tempo todo participativa, em termos de dinâmicas. A gente vai mostrar para o pessoal e eles podem aplicar na escola onde trabalham".

Ao responderem a pergunta "O que você entende por estudo do meio?", destacam-se respostas que incluem a percepção do entorno, a compreensão da realidade, além de transmitirem uma sensação de "movimento", com as palavras como: "excita", "exercita", "interagir", ao definirem essa técnica.

Phoenix: "(..) seria uma atividade em que você prestaria mais atenção nas coisas que você percebe (...) você excita a percepção da pessoa, do indivíduo. Excita a percepção para determinadas coisas, pode ser a percepção de algo (...) você pode dirigir esta percepção ou não".

Taurus: "(...) é você ver aquilo que nunca viu e achava que não existia, né? Observar seu entorno, num ponto específico, e de repente isso vai ampliando e você acaba observando o entorno da sua vida, da sua história, e tudo mais. Não só naquilo que é matéria, que é físico, que você está vendo, mas de repente a coisa até se estende para um lado espiritual para uma série de coisas que está aí, que existe mas que de repente você não se tocou. Você passa a exercitar esse instinto de observação, e acaba formando conceitos diferentes e valorizando mais sua própria existência". 
Hercules: "Significa o indivíduo estar em contato com um determinado ambiente, que não precisa ser natural, fora da sala de aula, fora do local de estudo teórico, onde possa estar tentando interagir com esse ambiente, tocar, sentir esse ambiente e se colocar dentro de um contexto mais amplo de existência desse indivíduo. Dentro dessa questão da interação dele com todos ambientes possíveis da convivência dele".

Há também respostas mais sintéticas:

Apus: "È ter um contato, numa parte mais prática e desenvolver um olhar obre essa realidade".

No início da entrevista, Centaurus afirma que não tem trabalhado como educador ambiental, no entanto, há componentes apreendidos de seu depoimento, que permitem afirmar que ele tem uma visão complexa sobre o estudo do meio, não apenas por citar Morin, mas também, por sugerir uma reflexão filosófica, pois remete à existência do ser e que, talvez, tenha se perdido.

Centaurus: "Você poder pensar num método de estudo do meio que respeite essas novas visões que o Morin está propondo, acho bem legal. O estudo do meio, eu acho que é um modelo lúdico que você tem de botar o indivíduo para pensar onde ele está fazendo, olhar o que está fazendo, onde ele mora. É uma questão filosófica em essência, é você fazer a pessoa fazer uma reflexão filosófica dentro do que ela está fazendo, isso é fundamental, é uma coisa que se perdeu, eu acho".

Os entrevistados reconhecem a importância da técnica para a compreensão da realidade e mesmo de uma visão mais complexa sobre ambas. Sabem defini-la e afirmam que a utilizam, o que foi comprovado pelo acompanhamento in loco.

Compreende-se que educar, através ou não de estudos do meio, é mais que realizar a contento uma profissão, um trabalho ou atividade; pois traz embutida uma necessidade/intenção - a de se expor ao outro - idéias, conceitos, paisagens, sonhos - 
e compartilhar propostas na perspectiva de que aprender a incerteza da condição humana seja, talvez, uma necessidade para buscar melhores condições de vida.

\subsubsection{Pertencimento}

Entre todos os entrevistados nessa técnica, há apenas uma resposta considerada negativa, a de Apus, pois afirmou não saber o que é pertencimento; no entanto, há depoimentos - sintéticos ou complexos - bastante interessantes nas outras entrevistas semi-estruturadas.

Apesar da resposta inconclusiva e até indignada de Crater, quando se perguntou o que entendia por pertencimento: "Eu odeio essa palavra, eu li muito sobre isso, mas o que é?" Ela continua e complementa com a seguinte frase: "Acho que é você sentir que alguma coisa é importante pra você, é importante e faz diferença na sua vida“.

Novamente sintética, Auriga afirma que pertencimento é "cidadania planetária".

Parece nítida a dicotomia entre as compreensões de pertencimento, uma pelo menos na esfera da utilidade, da função, do papel das coisas num plano da razão:

Columba: "É se sentir pertencendo àquele ambiente, que aquela planta é sua e você também é dela, que todo mundo tem o seu papel dentro do ambiente. Você pertence àquele ambiente $\mathrm{e}$ aquele ambiente pertence a você também, pra você não se sentir algo de fora daquilo".

Cetus: "Eu também vejo um outro lado, uma outra interpretação que, por exemplo, na área da pesquisa científica em que eu atuo também, vejo algumas pessoas que talvez se utilizem disso para achar que (ao contrário) o ambiente, a natureza, os animais, pertencem a elas ou ao grupo delas. Eu me encaixo fazendo parte de uma coisa bastante complexa“.

Hydra: "Primeiro é eu sentir o meio, conhecer pra depois me sentir parte dele. Você só protege o que você conhece, o que você ama".

Outros depoimentos trazem claramente a questão sociopolítica preconizada nos ideais do ambientalismo: 
Centaurus: “(...) estou chegando à conclusão de que a gente só pode pensar numa construção social, se as pessoas estiverem colaborando e se sentindo donas daquilo de alguma forma. $\dot{E}$ isso que seria o sentimento de pertencimento. Eu acho que esse termo, que eu ouvi pela primeira vez lá no curso, é fundamental nisso que eu estou querendo trabalhar (...) a sensação de pertencimento que o cara vai ter, a postura vai ser outra (...) na hora de trabalhar com a lei, e a sociedade inteira como um todo...por mais que ela vai mexer...surge um produto que eles se mobilizaram para poder construir (...) tudo no Brasil é o estado que faz, ou o mercado, nada tem uma construção coletiva no Brasil. As coisas são feitas e entregues para cada um fazer a sua parte, esse é um erro crasso no nosso procedimento de construção, e isso é uma das coisas que eu quero estudar: como a gente pode pensar nestes modelos de participação das pessoas".

Delphinus: "De fazer parte, lembra uma coisa de participação, mas isso por que ficou na nossa cabeça aquela discussão de pertencimento, de que quando você pertence você passa a participar. Eu vejo como um monte de setinhas, uma coisa levando para outra. Principalmente com aquele filme que a gente viu, né? O "Bagdá Café", que mostra bem claro a mudança de postura que a pessoa tem quando ela sente que pertence àquele sistema todo, onde ela está, no espaço dela. Pertencimento eu vejo como uma grande arma da Educação Ambiental, a partir do momento em que ela se sente pertencer ela vai conseguir modificações".

Phoenix: "Nossa! Pertencimento é o que eu chamo de enraizamento. Sem pertencimento, você não tem vínculo.(...) Pertencimento é a tua orientação, é você saber não só de onde você veio, mas que você faz parte, que você pertence a alguma coisa maior e que você tem uma responsabilidade, que você não é simplesmente um indivíduo solto". 
Taurus: "Pertencimento significava e passou a significar muito mais depois do curso de especialização que a gente fez. A gente ouviu muito isso. Você olhar para a natureza, para o meio ambiente e se sentir parte dela? Assim como ela faz parte de você, você também pertence a esse contexto. O sentido desse pertencimento é exatamente a consciência de que você pertence a esse universo todo, a esse meio ambiente de que tanto falam e que nem tanto fazem por ele“.

Construir uma rede, enraizar, participar de uma malha, o entrelaçamento de Auriga, tecer, é quase uma experiência escatológica, ou segundo Unger (2001), mística, de "não pretender enfrentar a crise sozinho e somente por si mesmo"; pois esse é o pior perigo nesse tempo de caos. Então, com o exercício da humildade, do diálogo com outros irmãos e da fraternidade, podemos encontrar caminhos onde não há caminhos (Unger, 2001, p. 153).

\subsection{Olhar horizontal}

Esse olhar, denominado horizontal, percorre as técnicas apresentadas no olhar vertical, buscando-se, nas discussões sobre estudos do meio e pertencimento, uma síntese que retrate o que ocorreu ao longo do tempo da pesquisa. Pelo seu caráter conclusivo, considerou-se mais oportuna a sua apresentação como parte das considerações finais.

\subsection{Olhar transversal}

Apresenta-se aqui um continuun de dois sujeitos, ao longo do curso e após seu término, acrescentando-se o acompanhamento in loco de Phoenix e o laboratório conceitual de Hercules. Sendo assim, alguns trechos já citados anteriormente se repetem. A escolha por apenas dois deles foi ponderada pela extensão dos documentos, e por considerar-se que ilustram, pelo menos em parte, os trabalhos desenvolvidos. 
Neste item, estão entre aspas as transcrições literais das falas e textos de Phoenix e Hercules, entretanto, há outros que apresentam uma síntese através do relato da pesquisadora.

\subsubsection{A síntese de Phoenix}

\subsubsection{No 1으 tempo}

Partindo do "ponto zero", em setembro de 2000, ela revela que foi monitora ambiental e realizou estudos de meio urbano e natural (cerrado, mata atlântica, restinga). Compreende que estudo do meio é a leitura e interpretação do ambiente urbano e espaço natural, com sua dinâmica e interdependências.

Diz que é possível, a partir de um estudo de meio, haver aprendizagens com o exercício da interpretação, pois esse é um exercício de crítica. Acrescenta que a percepção do mundo exterior e das necessidades interiores é o ponto de partida para a elaboração de alternativas construtivas e a base para qualquer ação relativa ao meio ambiente.

\subsubsection{No $2^{\circ}$ tempo}

Em Itatinga, em janeiro de 2001:

"Inscrevi-me no curso de especialização pensando neste encontro. Eu vim com muita ansiedade e, meus objetivos foram parcialmente atingidos, porque aqui eu descobri que o que eu quero não é isso aqui que vai suprir. Então estava procurando alguma coisa aqui que não seria este encontro que iria suprir. $A$ importância desta atividade em Itatinga é que reforçou uma linha de trabalho que até então desenvolvo, questiono e venho trabalhando: será que isso é uma maneira legal trabalhar? Não é muito solta? Essa história de não trabalhar com ensino formal (...) estava ficando em dúvida pelo próprio perfil do nosso grupo que só fala em escola. O importante deste trabalho em Itatinga, é que serviu para reforçar o que venho fazendo. $O$ que foi extremamente positivo foi a trilha de surpresas e o solo, pois já valeram o encontro todo. As respostas que estou esperando ter de fora, neste solo descobri que é dentro, é aqui dentro que tenho 
que procurar resposta, dependendo menos de um diálogo vindo de cima. Isso foi muito bom".

Na transcrição da entrevista semi-estruturada, no dia 4 de janeiro de 2002, no restaurante do Hotel Eldorado - São Paulo/SP.

Você tem participado de alguma atividade: aulas, cursos, profissional dia-a-dia, etc como Educadora Ambiental?

"Tenho, tenho participado".

Pretende continuar a participar em 2002?

"Sim. Já tenho, inclusive, projeto formalizado no ano passado, a ser aplicado este ano".

Explique melhor. Quais são estas atividades?

"Eu trabalho basicamente com dois segmentos. O primeiro segmento é o de monitores ambientais que em outros estados brasileiros são conhecidos como condutores de visitantes. Ou seja, nós desenvolvemos junto com esses monitores ambientais uma série de práticas de interpretação ambiental. O outro segmento é um para o qual eu fui convidada o ano passado. É a implantação de uma trilha perceptiva no Parque Estadual do Jaraguá (...) no Núcleo de Educação Ambiental do Parque Estadual do Jaraguá, aqui em São Paulo. Uma trilha perceptiva destinada a deficientes visuais. Existe a tese de mestrado da Carla Senna que é o ensino da Geografia através da trilha perceptiva dentro do Parque Estadual e, a gente vai entrar, enriquecendo, trazendo outros elementos da Educação Ambiental numa perspectiva holística para enriquecer o trabalho".

Qual ou quais temas tem trabalhado nesses dois segmentos?

"Basicamente tem dois temas. Você tem os grupos que têm necessidade de conhecer o ambiente no senso comum. Ah! O que é isso? É mangue! Olha como é! E tem o outro grupo, que é bastante forte também, que quer o desenvolvimento da 
percepção. É um trabalho muito parecido com o Cornell, é adaptado".

Usando estudo do meio? Por que você acha que o estudo do meio está sendo utilizado?

"Estudo do meio pra mim, é o meio, desde a cidade onde você está até o ambiente natural. É a base para a gente perceber. Eu vejo que como professora, a minha experiência se iniciou numa empresa que realizava estudos do meio para escolas de classe média aqui em São Paulo. A própria prática de estudo do meio com aquela empresa e com as crianças e com adolescentes, eu percebia que, comparando com um trabalho que eu tinha em sala de aula, era muito mais rico. O estudo do meio permitia um entrosamento e uma liberação do indivíduo muito maior. Um grau de amizade, de calor humano de envolvimento com aquilo que as pessoas estavam pretendendo desenvolver. O desenvolvimento era muito maior e, os resultados advindos da percepção (...). Quando você vai para o estudo do meio e o objetivo é você perceber aquilo, perceber com o tato, perceber com o paladar, perceber com a visão, perceber com o olfato, a riqueza de aprendizado e na produção de conhecimento é infinitamente maior".

Descreva qual é o público nos dois segmentos que você vai trabalhar, tem faixa etária?

"Não existe uma faixa etária. Nos monitores ambientais eles atendem desde escolas até grupos de terceira idade. E no grupo de deficientes visuais, a mesma coisa, porque você tem deficiente de qualquer idade. O que vai variar no grupo de deficientes visuais é que tem deficientes que necessitam de uma adaptação. Você tem desde crianças que tem $0 \%$ da capacidade da visão até pessoas que vão perdendo gradativamente. Então, a gente fica muito atrelada com as escolas públicas que tem classes 
especiais. Por exemplo, no último grupo que eu acompanhei lá no Jaraguá, tinha uma garota de dez anos e um rapaz de trinta e três anos que tinha perdido a visão há dez anos atrás, em decorrência de um acidente. A experiência é muito rica, né? No caso do portador de necessidade especial é triplicada, sabe? Olha, triplica a emoção, a percepção, o resultado final. Nossa, é uma coisa muito legal!"

Desconsidero as perguntas de seis a 11 , pois estão respondidas e, vou direto para a de número 12.

Vou perguntar vários conceitos. Diga rapidamente o que significa para você: Estudo do Meio?

"(...) seria uma atividade em que você prestaria mais atenção nas coisas que você percebe. Estudo do meio é uma atividade que você excita a percepção da pessoa, do indivíduo. Excita a percepção para determinadas coisas, pode ser a percepção de algo. Você pode dirigir esta percepção ou não".

E o que é percepção? Percepção ambiental?

"Percepção é desligar um pouco as pessoas do piloto automático com o local em que elas vivem. Você passa 500 vezes na sua rua e não sabe que ali existe uma mangueira. Aí derrubam aquela mangueira e você continua sem saber que ali existia uma mangueira. A percepção ambiental para mim é uma maneira de você chamar a atenção do individuo sobre a maneira como ele se situa no mundo. Do lugar social neste mundo, no planeta. A partir da percepção, de como ele percebe o que o cerca, e como ele percebe a si mesmo, e daí gerar uma mudança de comportamento também. Percepção ambiental é fundamental para você pensar uma mudança de comportamento". 
Interpretação da paisagem, o que significa para você?

“Interpretação da paisagem pra mim é algo mais técnico. Eu não tenho uma discussão sobre o que seja uma interpretação da paisagem. Mas interpretação da paisagem é algo mais técnico, algo mais geográfico, mais racional. $E$ eu faço indiretamente interpretação da paisagem. Do que é transformado, do que chamar a atenção, do que é transformado, a leitura econômica, social e política que você tem da paisagem construída, aliás tudo é construído, né?".

Estímulo dos sentidos?

"Estímulo dos sentidos são técnicas, vamos dizer, pensadas, elaboradas, no sentido de permitir que as pessoas se liguem, se desliguem do piloto automático. São maneiras de se facilitar que as pessoas se desliguem do piloto automático. Que elas parem (...). Para que o lugar onde eu estou deixe de ser simplesmente um lugar construído, mais ou menos numa estética da década de $50^{53} \mathrm{e}$, eu começo a perceber outras coisas, que existe uma iluminação, que existe um ar condicionado, um ruído, é uma ampliação dos sentidos".

E meio ambiente?

"Meio ambiente? È uma palavra que eu procuro não usar mais, bem grosso modo é o lugar, o loco onde eu me insiro. É onde a gente está. Meio ambiente pra mim é onde estou".

Você procura não usar mais? Por que?

"Porque é um termo muito complicado. (...) A gente percebeu que aquelas pessoas que não tinham uma discussão avançada, aprofundada, achavam que meio ambiente era um matinho. Então defender o meio ambiente era defender o verde, era defender 0

${ }^{53}$ Ela está se referindo à decoração do hotel onde estamos, que data dessa época. 
pássaro, e não se preocupavam com as condições do seu bairro, com a carência do seu bairro. Trabalhar o movimento de valorização do Parque Estadual do Jaraguá perpassava pela valorização dos bairros adjacentes, perpassava pela valorização do ser humano. É um termo que lá no Jaraguá, por exemplo, a gente tem evitado usar porque está muito relacionado com essa visão compartimentada da natureza, visão muito biocêntrica, ser humano lá, natureza aqui".

Entorno, o que significa para você?

"Essa também é uma discussão que a gente faz. Eu utilizo entorno dependendo do que quero atingir. Então, por exemplo, as comunidades de entorno do Parque Estadual do Jaraguá. Quem são? São as comunidades do Jardim Sol Nascente, do Jardim Bonança, Jardim Felicidade, do próprio bairro do Jaraguá. Mas, dependendo do seu trabalho, se você utilizar entorno simplesmente como aquilo que está vizinho a você, empobrece. Agora, se você quer ter um alcance político, educacional, um alcance maior, aí você começa a estender o entorno para um outro conceito muito complicado que é o de região, quer dizer o entorno deixa de ser simplesmente aquilo que é limítrofe a você, e passa a ser aquilo que tem uma relação contigo. O bairro que tem a ver com você (...) Pirituba, Osasco. Aí, se o teu alcance transcender isso, você utiliza um entorno maior, mas, a priore, entorno é aquilo que está limítrofe, numa interferência incisiva, imediata".

Participação?

"Eu ainda discuto, brigo comigo mesma sobre o que seja participação. O que eu mais discuto são formas de participação. Eu confesso a você minha incapacidade de chegar a uma conclusão do que é participação. Acho que o que eu tenho 
discutido mais, me preocupado mais, são formas de participação. Participação infelizmente é um conceito que eu não tenho".

E pertencimento?

"Nossa! Pertencimento é o que eu chamo de enraizamento. Sem pertencimento, você não tem vínculo. É uma experiência individual. Sem ele eu não me sinto pertencente a um grupo, eu não tenho vínculo com ele, eu não me preocupo, minhas ações sempre são muito distanciadas daquilo. Eu não consigo ter uma visão global (...). Eu passei a me tornar uma pessoa muito mais preocupada, muito mais neurótica, muito mais ansiosa, na medida em que eu me senti pertencendo à raça humana, eu sou um ser vivo que faz parte do planeta Terra, que tem uma responsabilidade, né? Pertencimento pra mim é isso. Pertencimento é a tua orientação, é você saber não só de onde você veio, mas que você faz parte, que você pertence a alguma coisa maior e que você tem uma responsabilidade, que você não é simplesmente um indivíduo solto. Pertencimento pra mim (...) pertencimento é fundamental".

Tem mais algum conceito que tem utilizado?

"Os conceitos (...), por uma própria característica minha, de procurar o inesgotável, faz com que eu me fie apenas nestes conceitos apresentados, tá?".

Em que medida o curso de especialização e as atividades nele desenvolvidas, foram úteis para estas compressões?

"O curso me ajudou muito a organizar a cabeça. Eu não digo que eu saí de lá com a cabeça organizada, muito pelo contrário, no começo eu estava com a cabeça completamente desorganizada, aí eu fiz o curso, aí organizou, mas depois eu desorganizei de novo, que acabou numa crise epistemológica terrível". 
O que você acha da utilização do estudo do meio para a compreensão desses conceitos?

"Estudo do meio é fundamental para a compreensão desses conceitos. Eu não sei se é por um limite de criatividade, mas eu não vejo outra alternativa.

E para o ensino-aprendizagem, contribui?

"Contribui. Mas eu utilizo estudo do meio para uma compreensão social, uma sociopolítica do indivíduo. Por isso é difícil pra mim pensar em outro tipo de recurso".

\section{Segue a transcrição do meu caderno de campo e de gravações.}

Saída de campo - Phoenix

(Fotografo, filmo, gravo e anoto).

Dia nove de novembro de 2002, viajo de Piracicaba até o Parque Estadual do Piqueri, aproximadamente $170 \mathrm{~km}$ (Via D.Pedro e Fernão Dias até Mairiporã).

Público: 26 alunos do curso (para formação) de monitores ambientais que Phoenix coordena.

9h30 - Há 15 alunos presentes; pois os outros estão trabalhando e virão mais tarde. Phoenix está inquieta (como sempre), movimenta-se bastante, mas está atenta, participa, tirando fotos. Trouxe um bom equipamento fotográfico. A sala, ampla e arejada, também é bem equipada com som, TV, vídeo, retroprojetor.

Os alunos têm entre 16 a 40 anos. Marcos irá dar uma palestra e propõe uma dinâmica de ficar em pé, pensar numa paisagem de férias. Phoenix participa. Marcos pergunta como se pode atuar, contribuir para a construção de sociedades sustentáveis na região metropolitana da cidade de São Paulo. Pede para que escrevam no caderno. Phoenix faz anotações. Marcos propõe um trabalho em grupo. Phoenix conversa com ele, enquanto os integrantes dos grupos conversam entre si.

Aproveito para me aproximar de Phoenix, pois está sozinha, e pergunto porque chamou o prof. Marcos Sorrentino, lembrando que falara sobre a questão da solidariedade.

Phoenix: "A nossa proposta de trabalho é estar incentivando formas de organização solidária e cooperativas. Nosso grupo é 
composto, em quase sua totalidade, por jovens que já estiveram submetidos a condições sub humanas de vida. Já sofreram violência, agressão familiar, químico dependentes, prostituição. Quem vê agora, imagina que o grupo não tem problemas, mas quem vê aparência, não vê o que era no começo, em abril deste ano. Não digo que o curso foi o responsável por estar transformando, mas eu creio que a convivência e a expectativa de chegarem aqui, encontrarem outras pessoas e serem ouvidos e respeitadas suas vontades, fez com que eles procurassem outras atividades afins. Antes eles não viam perspectiva naquilo que estavam fazendo. Hoje conseguem ter uma perspectiva diferenciada. Dizem que isso vem ao encontro das coisas que tenho trabalhado no curso. E esses valores são os meus valores interiores, porque são valores que vão, inexoravelmente, me levar para uma condição melhor, de relação familiar, com o namorado, com o próprio mundo. Na verdade, acho que todos eles estão buscando sentido, como eu, enfim. E o Marcos foi chamado pois passamos por um problema muito sério, envolvendo 0 relacionamento deles. Viviam em panelinhas, brigas constantes. Nas avaliações escritas, eles pediam posição da coordenação sobre os colegas:sicrano é muito violento, não sabe trabalhar em grupo, etc. Essas habilidades sociais preocupavam muito. Convivendo com eles, a gente percebeu que não é só uma questão de habilidade social, é uma coisa de projeto de vida. Qual era o projeto de vida deles? Muitos não tinham projeto de vida: vou vivendo, deixa a vida me levar. Mas não é bem assim. Numa reunião com o grupo, buscamos justamente incentivar uma forma de organização em que a solidariedade e cooperação fossem fortes, por isso que chamamos o Marcos".

Peço para ela falar quais foram os módulos.

Phoenix: "O primeiro foi sobre a história da formação de São Paulo e ocupação da região norte-noroeste. Eu tive uma 
participação bastante ativa. A questão do homem e o espaço. Havia necessidade de um educador como facilitador da superação dos conflitos entre os meninos (...). Todo o tipo de problema o pessoal vem conversar contigo. Aí que exigiu mais da minha habilidade de educadora ambiental. A base da organização foi um curso do Vale do Ribeira de 180 horas. Eu participei em algumas etapas. Cada módulo era de cinco dias, aqui foram dois. Como eu sou monitora ambiental também, e tenho oportunidade de ter um trabalho (atuação) mais crítico, de reflexão com outras pessoas (...). Geralmente o pessoal de cada Unidade de Conservação trabalha lá e não tem mais nenhuma relação com monitor de nenhum outro lugar, então pelo fato de eu ter tido oportunidade de ir para a ESALQ, discutir com outras pessoas, outros lugares do Brasil também onde trabalhei, deu uma ampliada no horizonte. Baseada nisso, a gente propôs adaptações no programa do curso. Mas agora é lógico que o curso não saiu como a gente queria, muito longe do ideal Faço uma autocrítica pesada. Fico animada porque que a gente tem um grupo e essas pessoas estão interessadas em trabalhar de outra forma. Esse é o último dos módulos de capacitação, agora eles já são parceiros. Daqui já surgiram duas organizações independentes, mas solidárias e cooperativas entre si, que eu acho fundamental. Vamos procurar propor uma outra postura da gente, do mesmo modo de organização do capital. Nós não vamos trabalhar como uma empresa. Será que a gente precisa trabalhar numa empresa? Será que a gente precisa trabalhar com a ótica do capital? Se inserir na órbita do capital? Ou será que a gente pode trabalhar de uma outra maneira?".

Voltamos para a sala de aula. Phoenix faz o seguinte comentário com eles: "Antes eu achava que Educação Ambiental era um negócio completamente ( ... ) um trabalho feito num parque, num ambiente natural, numa floresta e tal. Não foi aqui que eu quebrei com essa 
noção, mas eu tive oportunidade de conhecer algumas pessoas que me ajudaram muito a compreender o significado do ambiente, o significado da vida: Marcos, Sandra. Hoje eu acho que Educação Ambiental não existe. Educação Ambiental é Educação. Não consigo fazer distinção entre Educação Ambiental e Educação. Educação pra mim é um processo difícil, muito duro de resgate da afetividade e da sensibilidade. Digo que eu não consigo ser uma boa educadora. É muita contradição no mundo e eu não consigo dar conta da contradição do mundo. Mas, por outro lado, se é um processo duro, difícil, você caminha contra a corrente. É difícil você lidar com cobranças dentro da sua casa. Mas eu insisto nisso: eu quero um mundo diferente, que respeite mais as individualidades, um lugar mais humano, de igualdade. Eu não consigo ficar aqui e me sentir bem pensando que os negros na África estão sendo massacrados. Pra mim é um negócio muito complexo. Educação pra mim é um instrumento de reversão deste estado de coisas".

11 horas - Os grupos começam a se apresentar. Após a apresentação, são aplaudidos. A entrada e saída (da sala) dos alunos é negociada (uma aluna está com a mãe doente, outras alunas vão fazer prova, etc). Phoenix participa com gestos, com o olhar, um sorriso e acenos às manifestações dos alunos diante da fala de Marcos.

Faço uma reflexão sobre a importância de eu estar atenta nas palestras, para tentar compreender o desenvolvimento das atividades que virão no final de semana: a avaliação no domingo, a participação de Phoenix. Aproveito também a presença de Marcos para, depois, poder comentar com ele sobre a minha atuação como pesquisadora.

13 horas - Finalização com avaliações individuais que eu estou gravando. Tive alguns pensamentos: a presença de Marcos é importante para eu rever a sua fala dentro do meu trabalho; e da subjetividade que posso incorrer neste trabalho, com a metodologia escolhida: o que, a que horas gravar, filmar, anotar?

Ao mesmo tempo que temos que nos manter "distantes", é necessário estarmos atentos para captar os momentos mais importantes. Dentro dos cursos de formação de 
educadores ambientais, poucos caminham nas perspectivas que Marcos trouxe, de olhar para dentro e para fora, o entorno e pensar a sustentabilidade.

Temos refletido muito (nesse grupo do qual eu faço parte) sobre as mudanças de paradigmas, de olhares, viver na tecnologia (desde quando?), mas valorizar também a compreensão da diversidade, da conscientização do que estamos vivendo e construindo (ou que queremos construir) para o planeta.

Quero tirar uma foto do flamboyant: ele é universal. Quem diria que está aqui no Juquery, casa de loucos, triste, abandonada. Ele, florido, não parece tão triste ou abandonado. Desde quando o Juquery recebe este grupo, para ensinar e aprender? Parece que o tempo parou, a hora do almoço passou, estão todos entretidos. É como se esse lugar fosse um local de resistência, de confronto, de energias renovadas, de possibilidade de expansão, criação.

Houve um momento com a água muito bom: alguns alunos que iam se apresentar pediam um copo de água (como os palestrantes), isto é, eles também tinham direito a isso. Após cada apresentação fazem uma "ola", batem palmas: ambiente alegre. As atividades foram bem programadas, divididas. Deixar para o final essa apresentação foi bem legal, pois os alunos se animaram.

23 horas - Eles estão apresentando os cartazes com história de vida: um aluno falou de uma experiência muito forte, do encontro que teve com Deus, a vida nas drogas.

Fazem uma confraternização, eu vou dormir.

Dia 10 de novembro. Passa das 9 horas - Estamos na sala de visitantes do Parque da Cantareira. Eles recebem uma ficha para preencher no percurso. São 12 alunos. Vamos para as trilhas da Bica e da Pedra Grande.

Passa das 14 horas - Depois das duas trilhas, uma professora convidada usa flipchart para resgatar as sensações: Mirante. Fauna que foi vista: bugio, esquilo, tucano, teiú, quati, cigarra. Vestígios: fezes, bituca (de cigarro), lixo, folha, comida.Textura. Sons: pássaros, grilos, estalidos das árvores, passos. Plantas: orquídeas, embaúba, ingá, araucária, samambaia-açu. Águas: bicas, água dentro do bambu, nas bromélias, a captação. Histórias: do parque, do palmito, museu, vacas, família de funcionário.

Ela pergunta sobre o pau com formigas, se é flora, fauna, etc. Aí o tema ecologia da floresta em unidades de conservação não se pode deixar de discutir: 
matas primárias e secundárias, fauna e flora, clima, solo, interações, interdependência e sensações. Conteúdos: campo das idéias, princípios e valores, procedimentos, atitudes. Ela diz:

"A gente precisa de pistas para aprender. Para que haja paisagem é preciso que se produza um encontro, no qual um sujeito disposto a observar se enfrenta com um objeto, com qualidades estéticas, culturais e afetivas".

Phoenix dá algumas dicas sobre como tratar um visitante:

"não se deve falar que a pessoa caminha mais devagar ou mais depressa, que tem dificuldade de caminhar em determinado tipo de terreno(...). Como monitores ambientais, com os nossos princípios, nós sempre vamos encontrar pessoas que tem uma opinião diversa da nossa e vão querer atrapalhar o nosso trabalho, ter tudo documentado é uma ferramenta, é um instrumento para você superar essa situação de conflito. Lembrem-se de documentar tudo o que estão fazendo".

Phoenix: "Pessoal do Jaraguá, Cantareira, Juqueri. Antes de formar, oficializar qualquer coisa, a gente precisa saber como funciona trabalhando junto. Então a gente fez um núcleo chamado Camarea, que é uma flor amarela, lindíssima, que foi encontrada no Parque do Juquery depois de 40 anos. O núcleo que é experimental, não a proposta: Núcleo Experimental de Educação e Monitoria Ambiental".

Tudo é feito de forma participativa. As formas de falar são para o aluno colocar sua opinião. Os alunos estão reagindo bem aos "combinados" para a formatura: churrasco, bebidas, quadra, piscina, etc. Phoenix tem bastante paciência para lidar com eles: faz comentários oportunos a cada fala, elogia, incentiva; toma cuidado com as palavras, propõem datas, não impõe prazos. Há força contida numa frase. 
Phoenix: Nós não somos do Juqueri, o Juqueri é que é nosso. Nós somos monitores do mundo. Nós estamos organizados ali, mas não é que nós somos daquele lugar".

Um aluno demonstra uma certa insegurança, pois é o final do curso. Phoenix coloca que o curso teve 104 horas teóricas.

Encerramento do curso: eles estão em círculo, embaixo de uma árvore, já é noite. Cada um fala uma palavra.

Phoenix: "Eu queria frisar o seguinte: nossa sociedade cultua muito a violência, então tudo que a gente faz é uma batalha, mas vamos tornar o nosso aprendizado menos sofrido, porque não é só com sofrimento que a gente aprende. Eu, graças a Deus, aprendi muita coisa com muito prazer, e vamos aprender a negociar; brigar menos e negociar mais".

19 horas Fizeram uma dança circular de vitória. Chove. Está escuro.

\section{Comentários sobre esta saída}

Sem dúvida, dois dias com esse grupo de monitores ambientais foi uma das experiências mais fortes que já tive dentro da perspectiva de trabalhar com formadores. Elaborar e apresentar algumas considerações, certamente, irão simplificar essa vivência, mas posso afirmar que: uma das palavras que melhor definem esse grupo, para mim, é resistência.

Várias vezes, durante os dois dias do acompanhamento in loco, essa palavra me veio à mente. Pela história de vida deles (que não foi gravada a pedidos), percebi que estão buscando uma brecha na sociedade para trabalharem, estudarem, enfim, exercerem seus direitos e deveres de cidadãos.

A experiência de fazer as duas trilhas com eles foi bastante positiva. Especialmente para realizar a trilha mais longa e de subida íngreme - a Pedra Grande. Talvez porque eu estivesse muito carregada de material (filmadora, máquina fotográfica, gravador, cantil e outros objetos pessoais) ou outro motivo que desconheça, alguns alunos mostraram-se bastante solidários, ora se oferecendo para ajudar a carregar algum material, ora pegando água fresca para reabastecer o cantil. Ensinei ao Maurício (um rapaz de aspecto "rebelde") a usar a filmadora. Aprendeu na 
hora! As imagens que tenho gravadas foram feitas por ele. Ensinei, também, a fotografar com a máquina digital. Ele se sentiu feliz (percebi pelo seu sorriso), não saiu do meu lado. Tomava água no meu cantil, carregando-o no seu cinto.

O Fusca, com quem fiz uma pequena entrevista na ida para o Parque da Cantareira, também se mostrou o tempo todo solidário e até preocupado comigo. Perguntou várias vezes se eu precisava de alguma coisa, por exemplo, de cobertor para dormir e outras coisas que não me lembro mais. No último instante do curso, depois da dança circular "para a vitória", quando fui me despedir, ele me pediu um abraço. Retribuí seu carinho e atenção daqueles dois dias com um abraço, mas também com meu olhar e votos de felicidades.

De maneira geral posso afirmar que o cansaço físico e o sono atrasado de todos os participantes e a intensidade das atividades dos últimos dias de um curso contribuíram para o "afloramento" das emoções. Eles ficaram meses se encontrando e, a partir de agora, estavam se colocando profissionalmente, enfrentando mais desafios.

\subsubsection{A síntese de Hercules}

\subsubsection{No $1^{\circ}$ tempo}

No ponto zero, em setembro de 2000, ele diz que ficou sabendo do curso por intermédio de um cartaz afixado no mural do PROCAM/USP, em São Paulo.

Procurava aperfeiçoamento profissional na área de Educação Ambiental, um desafio para desenvolver projetos de desenvolvimento sustentável, tendo como base a necessidade da mudança de comportamento da sociedade humana, em especial, setores responsáveis pela formação de opinião da população.

Diz que espera poder lapidar os conhecimentos nessa área em estudo e, adquirir novos conceitos e conhecimentos, que contribuam para uma capacitação profissional, de maneira a permitir-lhe elaborar projetos de Educação Ambiental e sustentabilidade. Atuou na área da saúde pública como biólogo, e atualmente é educador (PEBII). Participa de um grupo (Serelepe) que atua na educação aplicada às questões ambientais. Sua trajetória de vida converge para o ambientalismo, por uma questão de posicionamento político de questionamento sobre as bases de organização da sociedade humana moderna. O curso surge num momento em que procura se instrumentalizar para melhor entender e intervir nas questões referentes ao ambientalismo. 
Atualmente, o grupo ao qual pertence desenvolve vários projetos de estudo do meio em Campo do Jordão, serra do Japi e alguns bairros de São Paulo, buscando compreender o processo de ocupação do espaço e as relações socioambientais e suas perspectivas futuras.

Sua compreensão sobre estudos do meio não é cartesiana:

"Para compreender o meio no qual o homem está inserido é necessário um trabalho interdisciplinar, uma vez que a ciência é um elemento de leitura desse meio. E o agente criador da ciência é um só, o homem".

Hercules diz que pode haver aprendizagem com estudos do meio, utilizando as capacidades sensitivas e as estruturas de cognição de maneira planejada. Uma aprendizagem de natureza interdisciplinar com a fusão das mais variadas áreas de produção do conhecimento humano. Exemplo: estudo em áreas de desbarrancamento em encosta de morros, devido à construção de moradias em loteamento não planejado: desmatamento, esgotamento de recursos hídricos, não distribuição de renda e vários outros elementos.

\subsubsection{No $2^{\circ}$ tempo}

Em Itatinga, em janeiro de 2001:

"Vim com expectativa mais profissional do que pessoal, não sei se posso distinguir entre estas duas coisas, mas venho notando no curso como um todo é a construção das relações interpessoais. Construir um grupo. Eu trabalho com grupos há muito tempo. Grupos que se formam às vezes em uma semana, ficam juntos e depois vão embora no final de semana. Você vê isso de fora, não se vê integrado a ele. Está simplesmente coordenando, não faz parte deles. Sentia falta de estar vendo como é estar participando do grupo, da confiança do grupo, da relação das pessoas do grupo, ela cresce. Acho interessante pois você pode lançar mão de alguma forma mais técnica de algumas atividades e dinâmicas onde vai trabalhar de uma forma crescente esta questão. Acredito que chegamos a um ápice, desse ótimo de formação de grupo, 
confiança, onde as pessoas tem a liberdade de estarem chegando, conversando, do ponto de vista da confiança mútua. Esse laboratório é o que está valendo a pena. Observando as técnicas percebi que posso estar melhorando meu trabalho profissional, posso tirar alguns exemplos. De fato não gostei muito, não me sinto bem num local cheio de eucaliptos, prefiro mais natural, sem ação antrópica. Mas é necessário, e melhor ter eucalipto do que não ter".

\section{Entrevista semi-estruturada}

Dia 10 de outubro de 2001 - SESC Pompéia - São Paulo

Você tem participado de alguma atividade (aulas, cursos, profissional dia-a-dia etc) como Educador Ambiental?

"Eu julgo que sim. O tipo de trabalho que eu venho fazendo está de tal forma impregnado com a questão ambiental que acho que tenho feito Educação Ambiental quase que o tempo inteiro. Como professor de Biologia, também o trabalho com grupos, estudo do meio. O que eu faço é Educação Ambiental".

Pretender continuar com esse tipo de atividade?

"Pretendo. Tenho uma série da saídas marcadas com alunos para fazer estudo do meio na região de Bertioga, Parque Estadual da Serra do Mar e algumas outras saídas esporádicas para atividade vertical. Pretendo estar intensificando, fazendo minicursos para estar passando a experiência que eu tenho para as pessoas".

Pode explicar melhor essas atividades? Os alunos, os cursos?

"Eu tenho sete salas de $3^{0}$ colegial, nessa mesma escola trabalho com alunos de outros professores para levar tanto os professores como esses meninos fazer esse trabalho de estudo do meio. Fora isso as escolas da região me têm como uma referência para fazer essas atividades. Eu fundei uma ONG, através da ONG tenho feito trabalhos de Educação Ambiental, tem um site onde a gente 
oferece alguns trabalhos, mas estou afastado dessa organização. Tenho tocado meu trabalho normalmente. As pessoas me ligam, marcam e eu faço esse trabalho com alunos e professores. Essas atividades, geralmente, são trilhas onde passo para eles 0 aspecto biológico e ecológico, fisionomia da floresta, composição dos extratos florestais, tipos de interação que existem entre microorganismos, macroorganismos, clima, a questão ecológica mesmo. Sempre atrelando isso a um conceito da própria existência humana, da inserção do homem no planeta, do tipo de interação que ele tem, na sociedade humana e no planeta como um todo. A gente tenta fazer uma relação entre o equilíbrio existente na floresta, a dinâmica ecológica que existe e o desequilíbrio pelo qual a humanidade está passando e que tipo de ações seriam necessárias estar tomando pra melhorar o nível de coexistência entre as pessoas".

Quanto tempo dura essa atividade?

"Geralmente um dia ou final de semana, no Parque Estadual de Campos do Jordão ou Fazenda Vale encantado. Sempre reservas do Estado".

Você tem utilizado estudo do meio?

"Olha, isso é algo que eu gosto de fazer há muito tempo, desde o final da década de 80. Tenho um grupinho que a gente anda junto há muito tempo: tem um rapaz que é expert em esporte vertical, escalada, tem todo equipamento, ele dá cursos (...) eu faço trekking, caminhada de longa duração. Há muito tempo a gente faz isso, inicialmente, por diversão e depois cada um foi se profissionalizando. A gente fazia free lancer para a Folha de São Paulo. Fizemos reportagem fotográfica, os procedimentos que 0 visitante tem que ter para aproveitar a estadia. Fazia por gosto de estar levando as pessoas pra conhecer e passarem por situações de estarem num estudo do meio, em contato com a natureza, 
fazendo descobertas, conhecendo coisas, com um outro tipo de olhar. Uma coisa é você ir, fazer um passeio simples e outra é ir com uma proposta através da qual você tem condições de aprofundar um pouco seu olhar, sentir um pouco mais o local e ver a importância daquilo ali, para a existência da vida como um todo, sendo bastante generalista".

Como os estudos do meio puderam ajudá-lo a trabalhar estes conceitos? "Dentro da Biologia, você em contato direto com elementos vivos, seres vivos, tanto plantas quanto animais e microorganismos inclusive. Pode estar fazendo uma investigação a respeito da biologia, desses indivíduos no habitat natural. Se for imaginar que o indivíduo conhece isso basicamente através de um livro didático, de televisão, existe um distanciamento muito grande. A medida em que você coloca o indivíduo em contato com esses elementos, você tem condições de dar uma real dimensão para ele do que são esses elementos vivos, partindo para uma coisa mais complexa que são as interações ecológicas, compondo toda a questão do ecossistema. Na Biologia é muito fácil: geralmente, surgem muitas dúvidas em outras disciplinas por exemplo Matemática, Português, História e Geografia. Por exemplo Geografia: tem um trabalho que eu faço aqui no Vale do Paraíba que tem um contexto muito interessante para ser explorado de forma multidisciplinar, diria até transdisciplinar. É um local onde ocorreu o segundo ciclo do café: tinha uma cobertura vegetal de Mata Atlântica, a terra se esgotou, tem uma composição arquitetônica".

O que significa para você estudo do meio?

"Significa o indivíduo estar em contato com um determinado ambiente, que não precisa ser natural, fora da sala de aula, fora do local de estudo teórico. Onde possa estar tentando interagir com esse ambiente, tocar, sentir esse ambiente e se colocar 
dentro de um contexto mais amplo de existência desse indivíduo.

Dentro dessa questão da interação dele com todos ambientes possíveis da convivência dele".

Interpretação da paisagem?

"Para cada pessoa, para cada indivíduo a paisagem tem determinado apelo capaz de fazer suscitar dentro do indivíduo todas essas sensações, pensamentos, talvez um estado de espírito. Por exemplo, se estou diante de uma paisagem numa serra ou num vale, aquilo tem condições de me trazer lembranças, resgatar algumas coisas que inclusive podem estar me ajudando no meu dia a dia a enxergar as coisas dentro de outros contextos, é muito subjetivo".

Percepção ambiental?

"É você observar no ambiente e, conseguir extrair o maior número de informações que ele pode fornecer".

Estímulo dos sentidos?

"Isso é muito legal. Você aprender a usar olfato para perceber as diferentes fragrâncias, aprender a utilizar a visão para enxergar as diferentes formas das coisas, as nuanças, as particularidades, utilizar a audição, a perceber os sons, a textura das coisas. Utilizar os sentidos é uma ferramenta fundamental que nós temos, pra poder perceber com a maior profundidade possível as informações que o ambiente tem condições de te passar".

Meio ambiente?

"Eu entendo que tem três níveis, o 1, o 2, e o 3 . O interior, esse que está aqui dentro, eu, o meio ambiente interior, tem o que você convive com as pessoas mais próximas ou não; o convívio social e o maior: você, os outros, e o mundo todo, todos os aspectos 
naturais, subjetivos que nos cercam. Para mim meio ambiente tem extratos".

Pertencimento?

"Quando você pertence a alguma coisa significa você estar atrelado a algo que, se for tirado de você, vai te causar uma profunda dor, um profundo incômodo, e vou exagerar um pouco: vai te matar um pouquinho também. Pertencer significa fazer parte daquilo. Você mora numa cidade, num bairro, numa fazenda e aquilo ali faz parte, é uma expansão do seu próprio corpo. Acho que essa questão de sentir-se pertencente a alguma coisa, é mais ou menos sentir que o ambiente que te cerca é mais ou menos uma expansão de você, da sua vida".

Inserção do sujeito no meio ambiente?

"É uma preocupação muito grande, tenho uma forma de agir, de pensar. Até que ponto estou certo ou errado? Eu tenho um respeito tão grande pelas questões da natureza, do ambiente em si. Eu me vejo tão preso a essas coisas que isso me causa um profundo respeito em relação a elas. Uma simples folha que cai duma árvore pra mim tem um significado bastante grande e, as pessoas de uma forma geral passam desapercebidas, não conseguem perceber a importância de uma árvore, de um vaso, de uma determinada planta que está ali dentro, eles vêem com um distanciamento muito grande, como se aquilo estive lá e ele aqui. Eu acho que para o indivíduo estar inserido dentro do meio ambiente ele tem que entender, compreender, tem que se compreender. Tudo faz parte dele, moléculas estão girando e compondo o mesmo corpo, a pessoa precisa perceber que a vida é isso". 
Participação?

"Ela é fundamental. Hoje em dia tem uma tendência das pessoas para convergirem para o individualismo, cada qual a seu modo, no seu próprio mundo, sem levar em consideração que você interage com as pessoas e, com o mundo das pessoas. E a gente está num momento da sociedade onde impera um individualismo muito grande. Não existe uma preocupação real entre as pessoas, algo mais amplo que a solidariedade, a sensação de estar vivendo num mundo onde não está isolado, onde você depende profundamente de todos os outros elementos, os seres humanos, os elementos da natureza como um todo. As pessoas hoje em dia, talvez até pela lógica da sociedade de mercado neoliberal, são jogadas para uma situação, onde elas acabam achando que são indivíduos únicos. Que não depende das outras coisas e que tudo que ela precisa, ela precisa alcançar para ter para ela. A lógica que a gente vive de mercado é essa: a felicidade significa ter sim, e não, ser".

\section{Entorno}

"Seria o seguinte: $360^{\circ}$ que me cercam em cada momento da minha vida, onde eu estou. Em todas as dimensões possíveis: material concreta, espiritual. Quando eu penso em entorno me vem na cabeça a região que me cerca sob todos os aspectos: social, geográfico, histórico, espiritual".

Algum outro conceito? Veio alguma coisa na sua mente?

"Veio sim. A idéia de que eu tenha colocado as respostas muito fragmentadas. Eu tenho todo um pensamento que eu construí, em relação ao que eu faço, ao que eu optei por fazer, o que isso significa pra mim e da onde veio. Como essas coisas foram surgindo na minha cabeça, a idéia que me veio é que eu preciso amarrar mais essas questões". 
Em que medida o curso de especialização, e as atividades nele desenvolvidas, foram úteis para estas compressões?

"O curso veio num momento ótimo da minha vida. Essas coisas todas que eu faço ligadas geralmente à natureza, ao estudo do meio, ao esporte de aventura junto a natureza, que optei por fazer, tem um significado fantástico, que vem da minha infância de viver em Itatiaia. Sentia-me bastante incomodado com a agressão que eu via as pessoas fazendo: tiravam madeira da floresta e eu sempre tinha a idéia de que aquilo um dia iria acabar. Era um absurdo que aquilo acabasse, aquilo ia me matar e ia matar todo mundo: a falta de respeito, de consideração que as pessoas tinham com essas coisas da natureza. Isso sempre me incomodou e eu cresci com essa coisa na cabeça. Vim pra São Paulo, achava um nojo, por conta de toda essa coisa artificial que existe e, ao mesmo tempo, cheio de pessoas, seres humanos. Cresci, me formei e comecei a levar as pessoas de volta. Vamos levar as pessoas que não conhecem essas coisas, para conhecerem. As pessoas sempre se sentiram maravilhadas de descobrir um pouco mais e, tenho histórias de pessoas que foram uma vez comigo fazer uma trilha e nunca mais pararam, montaram grupos. Passei no concurso do "Adolfo Lutz", mas sempre quis fazer esse trabalho de criar grupos, levar as pessoas. Ecoturismo há dez anos atrás não existia no mercado. Sempre tive uma preocupação muito forte com a questão preservação, da harmonia das pessoas.Tenho uma inserção na questão política, militei em sindicatos, em partido político no PT, de estar buscando justiça nas pessoas. Eu tenho esse perfil, estavam espalhadas e eu precisava juntar. O que eu sou? Eu não sabia definir, quando fiquei sabendo do curso, vi naquele nome um pouco a síntese de tudo isso que eu devo ser. Fui pesquisar o que seria isso, Educação Ambiental, já tinha feito outros cursos, mas deixaram a desejar. O curso teve condições de estar me inserindo dentro de um caminho que, hoje posso dizer eu sei o que eu faço, eu sou 
um educador ambiental e sei o que significa ser um educador ambiental. Isso me deu essa segurança, essa referência muito forte. As leituras que foram feitas, a forma como pedagogicamente foi conduzido, muito coerente a prática pedagógica com o discurso que era colocado, toda literatura coerente dentro de uma linha, foi fantástico, e me deu esse alicerce, refinei aquela bagagem teórica que eu já tinha, deu uma lapidada boa, tem coisas que precisam ser construídas, mas é uma coisa muito nova que está sendo construída, trabalhada".

O que significa estudo do meio?

"Trabalhando com estudo do meio você tem uma ferramenta muito forte em suas mãos, pois não tem sentido você falar em Educação Ambiental, falar em preservação, na construção, na formação de um novo indivíduo capaz de conviver em harmonia na sociedade, no planeta Terra, se esse indivíduo não for buscar a experiência que a própria natureza tem para nos oferecer. Então, o contato do indivíduo com a questão da natureza é basicamente isso. A partir de uma leitura da natureza, de uma compreensão mais profunda de como é que se dão as relações na natureza e como nós nos inserimos, como compartilhamos com ela a existência aqui neste planeta, não tem sentido você não buscar e sair para dar uma real noção pra essa pessoa, bastante práticas e objetivas do está tentando passar para ela".

E estudo do meio pra relação ensino-aprendizagem?

"Fundamental, aí eu já trago essa questão do estudo do meio pra outros aspectos inclusive. Por exemplo, a escola por meio de resolução de problemas reais. Você está numa escola, numa comunidade, num bairro, numa cidade com algumas especificidades, alguns problemas específicos tanto na questão profissional, mercado profissional daquele setor, tanto na questão ambiental, na preservação dos aspectos culturais. Cada 
sociedade, cada comunidade tem seus problemas imediatos, e eu acredito que a escola, neste sentido, pode estar levando esse povo para o estudo desse meio, ensinar um indivíduo a fazer um estudo do meio de problemas reais do seu entorno, onde isso vai funcionar como um laboratório onde vai estar elaborando soluções para aqueles problemas e, estar fornecendo essas soluções para a sociedade onde ele pertence. Seria talvez uma forma de estudo do meio bastante refinado, objetivo".

\section{É a minha $1^{\circ}$ viagem para o acompanhamento in loco}

Dias 24, 25 e 26 de maio de 2002, em Cananéia/SP. Auriga e Hercules deram um curso de Educação Ambiental para 36 alunos de Biologia de duas universidades particulares de São Paulo/SP.

A saída foi às 8 horas (do sábado) de Cananéia, de barco, com destino à llha do Cardoso. Ao chegar na praia da ilha, Auriga iniciou as atividades, organizando um círculo para a apresentação das pessoas (nome, faculdade...). Em seguida os monitores do parque estadual chegam para acompanhar a visita.

Auriga coloca que irão falar sobre Educação Ambiental, fazer vivências, visita no manguezal e irão construir, juntos, os conceitos que serão vistos.

Fazem uma dinâmica de aquecimento com vários movimentos corporais. Ela lê um trecho do Joseph Cornell que fala da harmonia, da proximidade à natureza "infindavelmente magnífica". Depois disso dá alguns comunicados gerais.

Seguimos para o centro de visitantes para trocar a roupa e deixar bagagens, pois eles seguirão para o manguezal trabalhar a percepção. Hercules fala dos sentidos, eles saem do mangue (eu filmo) e vão para a praia tomar banho.

12h30 almoço. Meu trabalho é dividido entre filmagens (é a primeira vez que uso a câmara), olhar a paisagem, observar o trabalho dos dois egressos e também os estudantes. Sinto-me investigando. Perguntando por que a toda hora.

14 horas, depois do almoço. Colaram cartazes no vidro com os cinco sentidos trabalhados no mangue (tato, olfato...) e um cartaz com os "conceitos" envolvidos. Seria interessante se eles pudessem se expressar também de outras formas, e não apenas anotando numa cartolina quais as sensações percebidas na trilha do mangue 
Hercules comanda a próxima atividade: os estudantes fazem um círculo na areia, depois um buraco bem marcado. Para o "aquecimento de idéias", uma brincadeira chamada "quem já fez?". Penso que as perguntas deveriam estar mais associadas à Educação Ambiental.

14h45 fazem corujas e corvos (do Cornell) sobre algumas questões do mangue. Faltaram perguntas. Em Itatinga também faltaram perguntas.

15 horas - dança das cadeiras cooperativas. Auriga quem comanda. Ao final pergunta porque não foi divertido. Falam que competição existe em todo o lugar, que eles têm que ter mais comunicação. Eu acho que podiam ter amarrado com a questão da competição no ambiente natural, isto é, ela é para sobrevivência, faz parte do ritmo, não há competição por "ganância" ou coisas assim. Explicando melhor, eles queriam competir e não cooperar. Hercules fecha bem, falando de posturas, da competição cooperativa. Auriga fala das atitudes do almoço, de terem deixado o prato na mesa. Da postura diferenciada que se deve ter nas unidades de conservação. Um estudante fala do consumo, de uma proposta de se restabelecer conceitos. Hercules fala do lixo, do padrão de consumo dos Estados Unidos: "Temos que debater e converter o quadro atual".

Anoto as falas de alguns alunos: "Cada um fazer a sua parte", "parar de fumar no ônibus". Essa última frase, para mim teria um ponto muito forte para participação dos estudantes, de exporem as idéias para Hercules e Auriga explorarem o conflito, a diversidade, a tolerância etc, foi o único momento que a maioria se colocou, opinou sobre fumar ou não no ônibus em que eles viajaram. Foi um momento "quente", onde poderiam ter sido incentivados a fazer um plebiscito, por exemplo, formar um pacto entre eles, etc. Foi um problema real que emergiu do próprio grupo de alunos.

Meus comentários depois, por "traz dos bastidores":

Realizar o acompanhamento in loco, as observações dos egressos, principalmente as primeiras, é bastante complexo. O pesquisador tornar-se observador, não é assim tão óbvio. Ao mesmo tempo, tem que estar atento com os registros, o manuseio dos equipamentos. Se é importante captar e registrar o máximo possível, preocupando-se com o externo, com a logística; percebe-se que mergulhar, ser observador da experiência do outro pouco tem de prosaico.

A ida à Cananéia trouxe algumas reflexões sobre a prática do educador, no caso, educador ambiental. O educador ambiental para se comunicar, transmitir sua 
proposta precisa deixar claro seu posicionamento. Afinal de contas, para que estamos ali? Essa pergunta foi feita a alguns dos participantes desse curso, que responderam que foram se divertir, estavam na praia, o dia estava lindo, além da animação geral dos universitários: a "galera".

Esse conjunto de condições: pessoas, paisagem, intenção e disponibilidade é importante, e compreender tudo isso com um olhar de fora e de dentro, faz a diferença do educador. Captar os sinais e responder as demandas das condições apresentadas. O momento mais forte que ficou desta saída, foi quando o próprio grupo de estudantes "deslocou" a atenção do curso e focou num fato que ocorrera entre eles: sobre os fumantes no trajeto São Paulo-Cananéia.

\subsubsection{No $3^{\circ}$ tempo}

Estamos em São Paulo, dia 7 de março de 2004. Marcamos o encontro num apartamento de uma amiga. Estiveram presentes: Auriga, Cassiopeia e Hercules. Houve uma seqüência de pequenas atividades (Anexo L). Apenas as colocações de Hercules, relacionadas a pertencimento foram consideradas.

Num dado momento do laboratório conceitual, leio para eles alguns trechos dos depoimentos dos egressos, sobre o que seria pertencimento. Houve uma discussão muito interessante e, Hercules trouxe uma dimensão do homem na natureza, no "mundo natural" como um diferencial.

"Você já pensou que um átomo de carbono do seu corpo pode ter pertencido à cauda de um dinossauro no passado? E aonde este átomo vai estar daqui uns tantos milhões de anos?"

"Quando falo em pertencimento sempre vem à minha mente a figura de algumas pessoas tradicionais de alguns locais, ou um lenhador, ou um lavrador, ele tem a marca do ambiente onde que ele vive, a coisa cultural. O pertencimento necessariamente tem que ter o indivíduo atrelado de tal forma ao ambiente em que ele vive, ele tem no corpo a marca de onde ele vive, o ambiente é uma extensão do corpo do indivíduo, é incrível isso, o sentimento de pertencer, eu penso que ele aflora mais quanto mais próximo de ambientes naturais a pessoa está. Não que não ocorra a pessoa se sentir pertencente, por exemplo, num grande centro 
urbano, claro que ocorre, mas quanto mais próximo de um ambiente mais natural, mais próximo das forças que a natureza coloca, mais forte o sentimento de pertencimento".

Numa outra reflexão Hercules associa pertencimento e a aprendizagem ao contato com a natureza:

"O cara quanto mais próximo à natureza, aprende com a natureza. É um outro elemento que ele tem de ensinamento dentro do processo de educação global do indivíduo. Ele aprende com os ciclos, aprende com a terra, aprende com a chuva, aprende com tudo, e isso vai impregnando esse cara, culturalmente. Ele fica impregnado culturalmente, ele pertence a tudo".

Finalizando a discussão, Hercules afirma:

"A natureza tem essa capacidade de ensinar mesmo, o contato do indivíduo, ela mexe, ela transforma (...). Você se percebe um pouco mais como um elemento, como bicho".

Para o laboratório social foi solicitado que fizessem uma síntese a partir das leituras dos documentos enviados. Hercules apresentou a seguinte síntese, na íntegra:

"Eu fiquei sabendo do curso de especialização em Educação Ambiental no PROCAM, quando na verdade buscava informação sobre curso de pós-graduação (mestrado/doutorado) nessa área. O curso de especialização foi o espaço que eu encontrei na universidade para estudar esse tema. Em minha trajetória pessoal e profissional sempre teve espaço o trabalho com educação Ambiental e a minha postura como cidadão tem como orientação o Ambientalismo.

O curso de EA foi conduzido pedagogicamente de acordo com o discurso de EA o qual propõe uma leitura integral e sistêmica do mundo, rompendo assim com a prática de um ensino cartesiano e 
fragmentado nesse sentido tem valor tanto o conhecimento cientifico e racional quanto o que surge subjetivamente a partir da interação do homem com o mundo.

No curso do primeiro ao último momento o processo de ensinoaprendizagem ocorreu de forma dialética. A concordância e os choques de idéias foram conduzidos de forma que ao final de cada discussão ou apresentação os conceitos trabalhados ampliavam-se o espaço de desenvolvimento do curso foi a "comunidade de aprendizagem" que se pretendeu formar, para que isso fosse possível, a formação de um grupo com uma boa coesão entre os atores foi fundamental. Então durante o curso discutia-se e praticava-se EA, sendo o curso um laboratório onde se experimentava a aplicação dos conceitos e métodos aplicados. Nos trabalhos que eu faço como educador ambiental eu passei a aplicar os conhecimentos obtidos no curso inclusive o método utilizado no curso passou a ser o meu principal referencial. Após o término do curso juntamente com alguns alunos egressos formatamos mini cursos de EA e EM tendo como principal parâmetro para a aplicação pratica. O que nos foi apresentado em Itatinga aplicamos nesse curso para alunos universitários e professores da rede municipal de ensino de Mairiporã e Atibaia , bem como para membros do IpeC. A leitura que se pretende fazer do mundo é complexa e em um curso de EA os conceitos devem ser construídos democrática e coletivamente para isso é necessário conhecimento e habilidade para saber conduzir o processo. Essa habilidade é importante no momento em que surgem os debates entre contrários, pois é nesse momento em que é possível romper com verdades e conceitos préestabelecidos, para construção de novos conceitos que passam a ser compreendidos e aceitos por uma coletividade. Nesse processo é necessário que cada integrante de um grupo perceba que a busca pela participação é o instrumento adequado para que 
um grupo obtenha sucesso alcançando os objetivos preconizados pela Educação Ambiental.

A EA é um processo que tem como objetivo a reeducação do individuo, procura discutir o atual estágio de desenvolvimento da sociedade humana e detectar os elementos e processos que contribuem para o "caos" sócio-ambiental que estamos presenciando no momento. Nesse sentido a EA visa contribuir com a coletividade numa busca por um novo modelo sócio-ambiental baseado no paradigma da Sustentabilidade. Sendo assim, pequenas ações desde mini-cursos até cursos de pós-graduação podem contribuir para que se crie uma rede de EA na sociedade, visando tornar seus objetivos mais próximos".

Considerou-se esta síntese bastante objetiva e completa, pois traz comentários significativos sobre o curso, e também sobre a compreensão de Educação Ambiental que esse egresso tem. Destacam-se suas impressões positivas sobre a proposta pedagógica participativa e dialógica praticada, que valorizou o espaço de "sala de aula" com oportunidades de aprendizagem contribuindo com a estruturação de um coletivo que colaborasse entre si.

Isso fica explícito em, pelo menos, um dos objetivos do curso, o de "propiciar uma formação comprometida com a transformação e o desenvolvimento profissional dos sujeitos participantes com reflexo na sua prática social"; e, da disciplina, de "propiciar aos participantes a construção e a difusão de atividades que incorporem a utilização do entorno no cotidiano", pois possibilitou transpor o que foi aprendido para outras realidades.

Há ainda, na síntese de Hercules, a compreensão de que a aprendizagem e a própria Educação Ambiental são um processo em construção, em que é importante se promover o diálogo, a tolerância e a compreensão da diversidade em situações de conflito; além de ser importante para o enfrentamento, sob o paradigma da sustentabilidade e da complexidade, da crise socioeconômica e ambiental em que se vive atualmente.

Essa síntese reflete alguns dos pressupostos expressos no plano do curso de especialização (APÊNDICE 1, p. 6-7), tanto no que se refere ao projeto de intervenção 
educacional "de ser de caráter prático, útil para a comunidade na qual está inserido o profissional/aluno e que possa ser incorporado a curto ou médio prazo pela instituição", quanto nos pressupostos metodológicos de "priorizar o trabalho coletivo do grupo de alunos entre si, com os docentes e com a coordenação do curso para que a aprendizagem se realize num ambiente de construção coletiva do conhecimento; e desenvolver princípios de autonomia, criatividade e solidariedade". Em vista disso, curso e disciplina foram considerados coerentes com a vertente da Educação Ambiental preocupada com a formação de pessoas em prol de melhoria na qualidade de vida.

A opção por trazer Phoenix e Hercules foi subjetiva, movida pela presença marcante que seus trabalhos e depoimentos tiveram no decorrer de toda a pesquisa. Para a pesquisadora, esses dois representam uma síntese do potencial de ensinoaprendizagem existente em cursos como o analisado, quando se enfocam os estudos do meio e, suas possíveis relações com o ideário ambientalista.

$\mathrm{Na}$ mitologia grega, através da simbologia dos nomes, Phoenix representa a transformação, o renascimento e a esperança, pois acreditava-se que, enquanto Phoenix vivesse, haveria esperança no mundo. Quanto a Hercules, sua figura remete facilmente à força, mas também à sabedoria.

Além disso, Phoenix e Hercules trazem nos depoimentos uma vontade de mudar; considerando-se, portanto, que expressar essa intenção, tendo em vista uma transformação numa perspectiva de autonomia e emancipação, pode contribuir com a utopia, conforme compreendida por (Tassara, 1998), de construção de sociedades sustentáveis. 


\section{CONSIDERAÇÕES FINAIS}

Tendo em vista a finalização desse trabalho e, após a apresentação, discussão e análise dos dados primários e secundários, seguem as considerações finais, retomando-se o problema, a hipótese e os objetivos formulados. Os resultados foram apresentados através do "olhar vertical" e do "olhar transversal", fazendo emergir compreensões, interpretações, diferenças e até questionamentos que os diferentes sujeitos tiveram sobre estudos do meio e pertencimento, discutidos através do referencial teórico. O "olhar horizontal" foi formulado e apresentado nestas considerações finais, buscando-se uma síntese elucidativa. Algumas dificuldades encontradas no decorrer da pesquisa também são apontadas.

Destaca-se ainda que, em algumas técnicas utilizadas para apresentação dos resultados, compreendeu-se ser relevante apresentar outros itens que contribuíssem para as discussões e considerações finais, como por exemplo: o próprio curso, a atividade solo e o labirinto da contemporaneidade. Os resultados indicam que, nessas atividades, houve êxito ao deslocar o participante da posição passiva de mero expectador, de coadjuvante, para que passasse a autor, protagonista do seu processo de aprendizagem, na busca por autonomia e emancipação.

Com relação ao problema do trabalho, é possível afirmar-se que, os estudos do meio podem ser uma vivência na qual as pessoas compreendem que a realidade é complexa, tendo-se como base a discussão da literatura (Ott, 1989; Nidelcoff, 1979; Mendonça, 2003; Morin, 2003) e também dos depoimentos obtidos; pois, explicitam as contribuições que podem advir desta técnica, pelas suas características, intrínsecas, de promover um ensino-aprendizagem diferenciado ao propor relacionar, analisar e interpretar, juntamente ou através da imaginação, intuição e sensibilização das 
pessoas em relação ao entorno e suas problemáticas. Dessa maneira e numa perspectiva mais filosófica, supõe-se que a utilização de estudos do meio venha a contribuir para que as pessoas sintam-se pertencentes, a ponto de intervirem para a construção de sociedades mais justas, dentro de uma perspectiva emancipatória, mas também contemplativa, ou, conforme Unger (2001) enuncia, com "uma postura existencial que se ponha à escuta da vida e de seus sinais", de forma que as pessoas sintam-se inseridas, enraizadas e pertencentes.

"Os alunos que convivem em diversos contextos culturais e naturais, e que têm suas habilidades respeitadas, poderão se tornar indivíduos que atuarão diretamente nos processos de transformação social fundamentais para a busca de um mundo mais igualitário. Conhecer outros ambientes lhes dão bases informativas que os capacitarão a avaliar as melhores estratégias para construir uma sociedade mais democrática, participativa e interativa" (Mendonça, 2003, p. 53).

Entende-se que a hipótese enunciada, de que os estudos do meio podem contribuir para a formação de educadores ambientais capazes de utilizá-los como caminho para se atingir objetivos educacionais e do ambientalismo relacionados ao conceito de pertencimento, pode ser confirmada, pois houve indícios desde o início da pesquisa, apresentados agora através de um "olhar horizontal". Isto é, perpassando-se pelos dados analisados nas diferentes técnicas, destaca-se a importância do conceito de pertencimento presente, mesmo que implicitamente no "ponto zero", com as respostas de Draco, Cygnus e Grus ao expressarem, respectivamente, a necessidade de que as pessoas incorporem o respeito e o entendimento sobre o ambiente em que vivem; que percebam o seu papel mais que social e biológico consigo e com o outro, desenvolvendo um forte elo com tudo o que as rodeia. Em "Itatinga II" esse conceito também emerge, com Circinus chamando a atenção para os problemas de uma localidade, onde o sentimento de raiz é quase nulo, pois falta às pessoas um sentido de equipe, que possibilite-as crescerem juntas. Ainda nessa técnica, fica evidente a importância que as atividades desenvolvidas em Itatinga tiveram para o sentimento de pertença do próprio grupo de participantes: o entrelaçamento a que Auriga tão bem se refere. As propostas de minicursos apresentadas por Auriga e Corona são 
consideradas bem fundamentadas teoricamente (Freitas, Morin, Nicolescu, 2000; Boff, 1999), além de ilustrarem como o referido conceito pode estar presente e vir a ser discutido em atividades didáticas. Também nos relatórios descritivo-analíticos, o pertencimento emerge, mesmo que em estado ainda de discussão e apreensão pelos sujeitos, que o traz de forma explícita, incorporado-o à práxis (Gutiérrez, 1988). Depreende-se, portanto, ser possível e necessário estar utilizando e discutindo o pertencimento em processos de ensino-aprendizagem, como também, torna-se necessário para compreensão da condição humana frente às questões aflitivas da contemporaneidade.

Compreende-se que o primeiro objetivo de descrever, avaliar e analisar a disciplina "Re-conhecendo o meio ambiente" e suas contribuições para o curso piloto de especialização "Formação de educadores ambientais para sociedades sustentáveis" foi atingido na medida em que fez-se um detalhamento das atividades implementadas no curso e na disciplina de onde suscitaram as contribuições teóricas, as práticas e até os conflitos advindos desta vivência, pois houve evidências de que os estudantes, agora egressos, farão uso de estudos do meio nas suas práticas profissionais, confirmadas pelas propostas de minicursos e verificadas no acompanhamento in loco. No entanto, a importância da disciplina extrapolou o âmbito teórico de difundir a utilização de estudos do meio como facilitador do ensino-aprendizagem. Ficou evidente, na discussão apresentada em "Itatinga II" e também no relatório descritivoanalítico, que a intenção de contribuir para as relações interpessoais e intrapessoais do grupo configurou-se pela utilização de estratégias e vivências adequadas entre os participantes, tendo em vista que elas se aproximaram e responderam às necessidades e motivações do grupo, bem como, possibilitou o acesso aos sonhos e sentimentos individuais para que cada participante buscasse compreendê-los e solucioná-los.

“(...) a posição normal do homem no mundo, como um ser da ação e da reflexão, é a de "ad-mirador" do mundo. Como um ser da atividade que é capaz de refletir sobre si e sobre a própria atividade que dele se desliga, o homem é capaz de "afastar-se" do mundo para ficar nele e com ele. Somente o homem é capaz de realizar esta operação, de que resulta sua inserção crítica na realidade" (Freire, 1977, p.31). 
Nesse sentido, contribuíram também a atividade solo e o "labirinto da contemporaneidade" que simbolizaram um encontro consigo, numa atitude reflexiva diante de uma proposta de introspecção sobre si mesmo e sobre a problemática humana apresentada.

Quanto ao segundo objetivo, de investigar, avaliar e analisar quais são as concepções que os egressos têm sobre estudo do meio e pertencimento, bem como as relações existentes entre eles, buscou-se respostas através do "olhar horizontal". Encontrou-se uma situação na qual os estudos do meio, para uma parte dos estudantes, ainda são realizados nos moldes de uma educação compartimentada, onde o estudante é visto prioritariamente como um receptáculo de conteúdos. Para outra parte deste grupo, no entanto, são compreendidos numa perspectiva mais complexa, como uma técnica que aproxima as pessoas - através da percepção - a um ambiente, mesmo que tenha sofrido ação antrópica; como um centro urbano ou um meio rural; mas também, em áreas naturais protegidas. Os que compreendem o potencial de utilização desta técnica como recurso pedagógico afirmam que é possível que haja aprendizagem através da sua realização, pois mencionam os processos cognitivos que ocorrem ao disponibilizar, facilitar, aproximar a informação sobre a realidade durante as vivências, destacando-se ainda a sensibilização e a utilização dos sentidos. O sentimento de pertença também é despertado a partir desse conjunto de significados, que se codificam no sujeito, singularizando a sua identidade em relação ao local onde vive, à sua cultura.

A visita ao terceiro objetivo, de analisar as propostas de estudos do meio que estão presentes nos projetos de intervenção educacional e nas propostas de minicursos apresentadas, revela, conforme indica a literatura (Pontuschka, 1994; Mendonça, 2003), que elas surgiram também com outras denominações, o que de certa maneira dificulta a mensuração das intenções de utilização, pela ausência de um detalhamento de forma e conteúdo. No entanto, o mais relevante, refere-se ao potencial de utilização da técnica, numa visão transdisciplinar apontada em algumas propostas, pois, é por meio desta visão "que reconhecemos a existência de diferentes níveis de realidade, regidos por lógicas divergentes, e que possibilitamos formar, a partir de um novo olhar, uma racionalidade que questione a rigidez das definições, o absolutismo da objetividade e a exclusão do sujeito" (Mendonça 2003). Para esta autora: 
"Um bom estudo do meio (...), possibilita um trabalho que se situa exatamente nos limites entre as disciplinas conhecidas e onde elas não se entendem, pois pode ter um caráter holístico e contestador do reducionismo cientificista e do método analítico. Aproxima-se, assim, das possibilidades da transdisciplinaridade, pois pode revolucionar o atual modelo de ensino, pôr em prática novos princípios e realizar propostas que construam o meio como espaço de vivência para a cidadania" (Mendonça, 2003, p. 52).

Obteve-se indícios, exemplificados nos projetos de intervenção de Draco e Corona, que houve a utilização de estudos do meio numa perspectiva mais holística, tendo-se em vista também, a construção de sociedades mais justas e igualitárias. Entende-se que a enunciação do conceito de pertencimento, com possíveis relações com a técnica de estudo do meio, emergiu no exemplo de Hydra, quando ela retornou à escola após uma atividade num zoológico e, mesmo realizado numa concepção mais tradicional, apresentou reflexões sobre a atitude dos estudantes, que ora catavam, ora espalhavam o lixo. Centaurus apresenta, no objetivo geral - contribuir para despertar e mobilizar a comunidade - a preocupação com o sentimento de pertença em relação à região em que estão inseridos. Nas propostas de minicursos constatou-se as intenções de utilizar os estudos do meio em áreas naturais protegidas e também em locais antropizados. As considerações sobre o conceito de pertencimento já foram apresentadas na reflexão sobre a hipótese.

Quanto ao quarto objetivo, de descrever e analisar alguns impactos epistemológicos e metodológicos sobre os egressos de um curso de especialização, denota-se, principalmente, no relatório descritivo-analítico e na entrevista semiestruturada, que o curso contribuiu para que alguns estudantes compreendessem e incorporassem a proposta de construção das comunidades de aprendizagem e, conforme explicitado em diferentes momentos, a aprendizagem advinda do curso de alguns conceitos chave do ambientalismo, como a participação, o pertencimento, a emancipação; e ainda, a importância da dimensão "social" e do "conflito", presentes nos questionamentos do ideário ambientalista e compreendidos a partir do curso, tendo em vista as afirmações de Delphinus e Indus de que a estrutura curricular dos cursos universitários que fizeram (Engenharia Agronômica e Ciências Biológicas, 
respectivamente), não explora o potencial e a necessidade de se inserir a dimensão social e educacional; acrescentando-se aqui a necessidade de conhecimento e tratamento das diferenças de linguagens e de culturas tão presentes no exercício dos profissionais quando vão ao campo. Os cursos de ciências aplicadas restringem-se, em geral, aos conhecimentos técnicos fragmentados, sem se fazer a "ponte" para a realidade e para que haja transmissão de conhecimento numa perspectiva emancipatória, de "uma ação educativa de caráter libertador" (Freire, 1977, p.25). O conflito existente entre as atividades de um "agrônomo educador" e a sua ação enquanto extensionista deve ser compreendida na perspectiva de que:

“(...) a substituição do procedimento empírico dos camponeses por nossas técnicas 'elaboradas' é um problema antropológico, epistemológico e também estrutural. Não pode, por isso mesmo, ser resolvido através do equívoco gnosiológico a que conduz o conceito de 'extensão'” (Freire, 1977, p.33).

Finalizando as considerações, os esforços para uma Educação Ambiental parecem estar em sintonia com a "educação popular" apontada por este autor, pois afirma que esta deve ter um objetivo fundamental para que possa "através da problematização do homem-mundo ou homem em suas relações com o mundo e com os homens, possibilitar que estes aprofundem sua tomada de consciência da realidade na qual e com quem estão" (Freire, 1977, p.33).

Assim, com a expectativa de que este trabalho possa contribuir com outras pesquisas sobre programas de formação de educadores ambientais, e também com outros cursos que derivem do ideário ambientalista apresentado, há alguns pontos, em relação à pesquisa, que merecem atenção:

1. considera-se que foi relevante o período de contato, de quase um ano, com os estudantes durante o curso, para todas as etapas da pesquisa. $O$ despojamento, a confiança e o interesse deles em contribuir, foi fundamental. Os questionamentos e oposições também contribuíram para que a pesquisadora refletisse sobre a sua pesquisa;

2. é necessário um cuidado permanente com os procedimentos metodológicos antes, durante e depois da coleta de dados, pela própria diversidade, tanto de 
técnicas, quanto dos materiais necessários em cada uma delas. O pesquisador deve assegurar-se que tem conhecimento sobre elas;

3. a análise e interpretação do acompanhamento in $10 c o$, com as técnicas utilizadas: observação, caderno de campo, gravação e filmagem, incorreu em grande subjetividade, deixando pouco à vontade, em alguns casos, pesquisadora e/ou egresso;

4. houve um certo desgaste na comunicação entre pesquisadora e egressos que pode ter sido ocasionado pelo longa duração da pesquisa ( $2 \frac{1}{2} 2$ anos), após 0 término do curso; e pela insistência da pesquisadora no contato com os sujeitos, para a realização da entrevista semi-estruturada, do acompanhamento in loco, da leitura e devolução dos materiais; e ainda, do laboratório conceitual;

5. com relação ao acompanhamento in loco, a proposta que se coloca é a realização de uma entrevista em profundidade com os egressos sobre a sua prática como educador ambiental, após realizar algum estudo do meio, buscando-se minimizar a subjetividade;

6. outros estudos poderiam advir dos documentos colecionados durante e após o curso piloto, devido ao grande volume de materiais e riqueza de olhares, que exemplificam certamente, um pouco da diversidade humana.

Enfim, está contido neste trabalho um resultado concreto após mais de 22 anos de inquietações. Felizmente, algumas dessas inquietações, foram se tornando pistas, ao encontrarem interlocução. As pistas se tornando caminhos, ao encontrarem-se respostas, principalmente na academia. Esse percurso ensinou também a não desistir, a depositar confiança naquilo que se percebe e se apreende a partir do contato verdadeiro com o entorno, principalmente o mais conservado. Há a necessidade de se imprimir uma qualidade no encontro consigo, com o outro, com os entes e as coisas.

Essa busca revela também a importância de se valorizar o simples, o que nos cerca; e a possibilidade de aprender através de um olhar contemplativo que o simples, é também complexo.

Há um trecho de uma música popular, "Catingueira", que retrata a sobrevivência de uma árvore do sertão nordestino, pela capacidade que ela tem de lançar profundamente suas raízes em busca de água. Além disso, há profunda sintonia com 
algumas questões apontadas, tais como: a realidade, a sobrevivência, a resistência, o enraizamento, o diverso e o poder de transformação do ser humano:

Catingueira "Catingueria, catingueira Diz o segredo que existe Que somente a catingueira Enfeita a paisagem triste Catingueira, se és feliz, Não zombes nunca desse teu contraste Segura tua raiz E pede a Deus que ela nunca gaste. Tão resseca a umburana A terra quente e rachada O marmeleiro se enrama mas não agüenta a queimada Sentindo como quem ama A terra quente pede invernada Quanto mais seca a ribeira A catingueira fica enfolharada (...)" Onildo Almeida e José Maria Assis (Unger, 2001, p.116). 
ANEXOS 
Anexo A

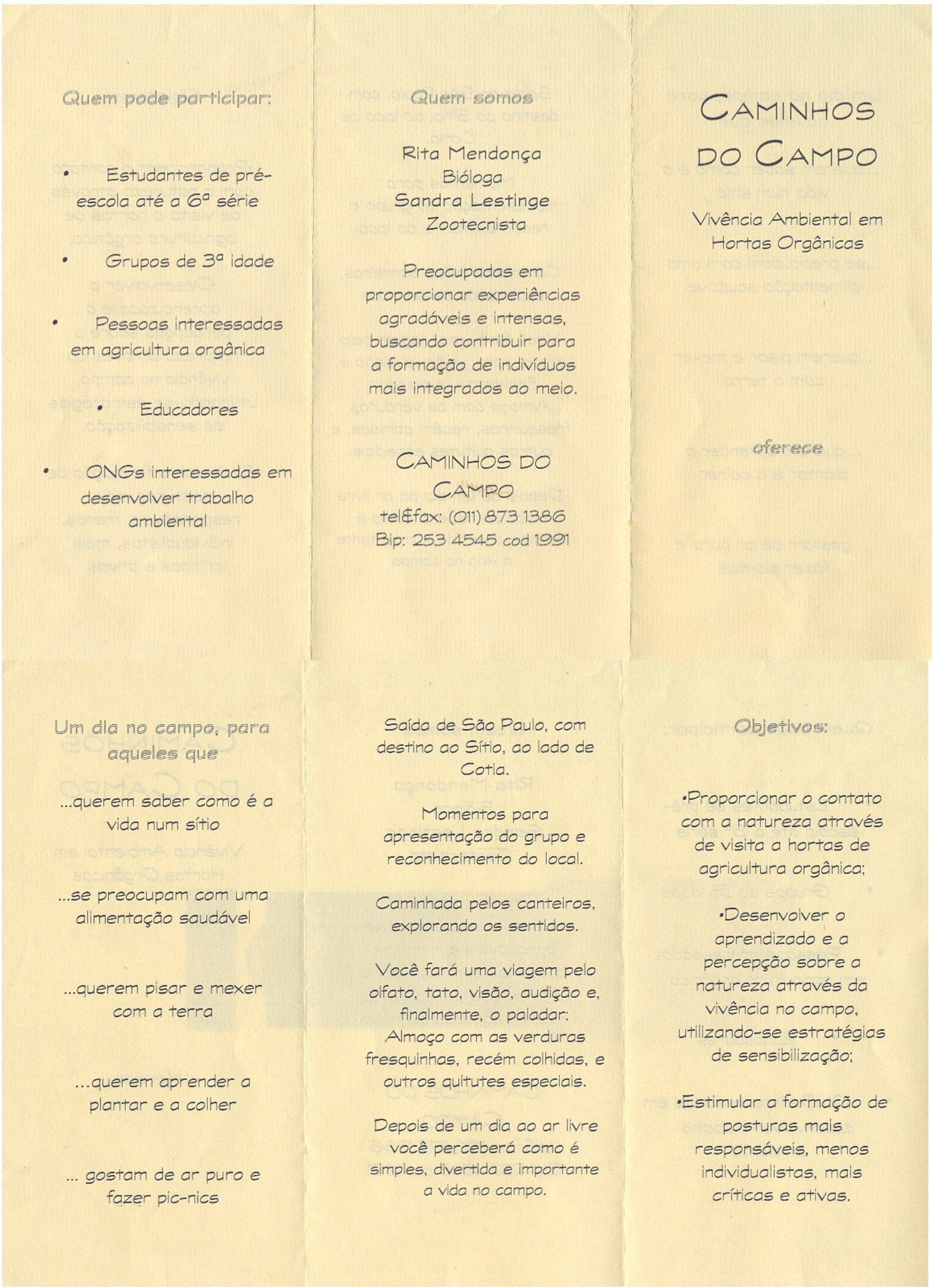




\section{Anexo B}
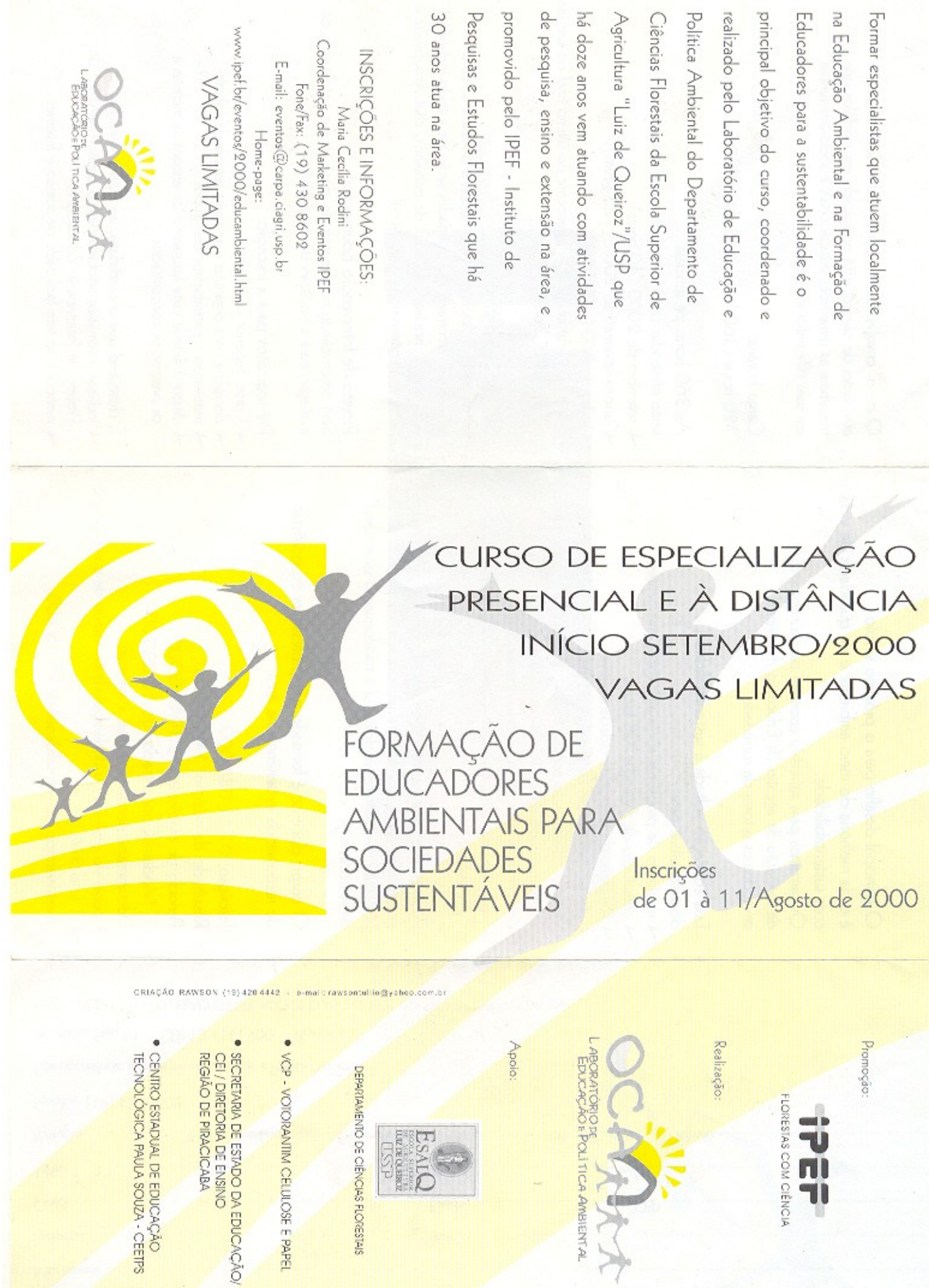


\section{Anexo C}

\section{I) Ponto zero}

Gostaríamos de colher algumas informações, e para isso, pedimos que responda, da forma mais completa possível, as questões abaixo, na seqüência em que se apresentam.

Aproveite este momento de reflexão!

1) Conte um pouco como chegou ao curso: como ficou sabendo, o que o(a) estimulou a se inscrever e se matricular, quais foram as suas dificuldades.

2) O que espera do curso? Quais são as suas expectativas?

3) Qual é a sua trajetória profissional? Em que ponto ela se aproxima e se distancia do meio ambiente?

4) Em que ponto desta trajetória se encontra o curso?

5) Você já realizou algum estudo do meio? Quais?

6) Qual é a sua compreensão sobre estudo do meio?

7) Você acha possível que a partir de um estudo de meio possa haver aprendizagens? Quais? Como? Exemplifique.

8) Quais aprendizados você teve que considerar como relevantes a partir das suas experiências com os espaços naturais ou quais você considera importantes? 


\section{Anexo D}

\section{SUGESTÃO DE ATUAÇÃO NA MONITORIA DO II CICLO DE CURSOS}

Aos alunos e alunas do Curso de Especialização,

A atuação como monitor ou monitora de um dos cursos desse II Ciclo de Cursos para a formação de educadores para sociedades sustentáveis está alicerçada nos parâmetros que vimos construindo o Curso de Especialização, quer seja, num processo de incansável aprendizado, onde todas as questões ou acontecimentos são motivos para promover reflexões sobre nosso projeto de vida e de trabalho. Nesse sentido, a monitoria, assim como, a sua participação nos demais eventos devem estar respaldados num aprender a fazer, na dialogicidade, na criticidade, no trabalho coletivo, na realização de tarefas em grupo, na promoção e valorização das interações sociais entre tantas outras coisas.

Para que isso aconteça de uma forma em que consigamos otimizar os esforços para esse empreendimento sugerimos algumas etapas específicas para sua atuação na monitoria, com o objetivo de facilitar a sistematização desse evento e a sua socialização para o grupo.

No caso dos cursos em que a monitoria será desenvolvida por dois ou mais alunos, sugerimos que seja feito um acordo prévio entre estes alunos para o contato inicial com o docente e também organizar a comunicação entre vocês.

O contato com o docente do curso que você vai monitorar deve ser de sua iniciativa, para tanto, estamos fornecendo e.mail e $\mathrm{n}^{\circ}$ do tel. dos docentes, na lista anexa.

\section{Etapa preparatória:}

- O envolvimento

a) Iniciar contato com o professor ou professora do curso;

b) Estabelecer formas de diálogos para seu envolvimento;

c) Estabelecer os acordos para sua participação como monitor(a);

d) Planejar juntamente com o professor do curso, os momentos da aula que seriam importantes de serem gravados em fita cassete;

\section{Etapa da realização:}

- O acontecimento (a realização do curso):

a) Traçar o perfil dos alunos participantes ;

b) Mapear os aspectos gerais do desenvolvimento do curso;

c) Registrar os temas trabalhados(conteúdos e bibliografia);

d) Observar as interações e os diálogos ocorridos no decorrer do curso;

e) Indicar as estratégias (metodologia e dinâmicas) utilizadas e a sua relevância;

f) Situar a participação da monitoria;

g) Avaliar o processo na perspectiva do professor, dos alunos e da monitoria.

\section{Etapa do relatório:}

- A reflexão

a) Registrar e sistematizar as informações observadas e experienciadas nas etapas anteriores;

b) Disponibilizar na Conferência Eventos esse relatório até 20/02/2001.

Estamos certos de que a vivência na monitoria e sua socialização para os demais colegas do curso contribuirá para fomentar o projeto de intervenção educacional, bem como, a sua formação como educador. Para tanto, a Sandra coloca-se a sua disposição no RITS (conf. eventos) para possíveis esclarecimentos para a realização desse trabalho.

Abraços,

A coordenação 


\begin{abstract}
Anexo E
Parâmetros de Referência para uma Avaliação Constante do Educador Ambiental (turma I - 10. Encontro) julho 2001.

"A Educação Ambiental é um processo educativo que busca despertar no ser humano um novo olhar para a realidade, através da transdisciplinaridade, contribuindo na construção de valores que potencializem o equilíbrio entre as relações com o Eu, com o Outro e com o Meio Ambiente".

"O Educador Ambiental é um indivíduo que sente profundas inquietações com o "Estado das Coisas" das questões sócio ambientais, e, imbuído de um compromisso político, busca resgatar valores humano para uma prática baseada na participação, contribuição e reflexão, em nome da construção de uma perspectiva sustentável".
\end{abstract}

O Educador Ambiental:

1. É um indivíduo compromissado com as questões sócio-ambientais;

2. Trabalha em prol da construção de um novo olhar da realidade e de uma nova postura, ética e responsável, frente às questões sócio-ambientais ;

3. Tem habilidades e competências para propiciar integração, participação, emancipação e potencializar ações transdisciplinares;

4. Faz uso dos recursos e ferramentas pedagógicas para desencadear processos de ensino aprendizagem;

5. É aquele que tem um olhar perspicaz sobre a contemporaneidade e suas realidades;

6. Respeita a diversidade;

7. Sabe enfrentar e dialogar com as incertezas;

8. É solidário e humilde;

9. Tem capacidade de conceber e executar projetos;

10. Usa e abusa de todos os sentidos e sentimentos para as leituras e compreensão das várias realidades;

11. Sabe captar a memória, os anseios e as necessidades do grupo com que irá trabalhar;

12. Respeita os tempos das soluções e decisões;

13. Respeita e valoriza a cultura das comunidades/grupos;

14. Conhece o limiar da sua proposta de ação;

15. Sabe procurar parceiros;

16. Sabe facilitar processos sem conduzi-los;

17. Utiliza os conflitos como ferramentas de transformação;

18. Identifica o papel dos atores sociais dentro das crises sócio-ambientais;

19. Fomenta processos de emancipação de grupos e indivíduos;

20. Percebe a Educação Ambiental como um ato político;

21. Percebe o aspecto social do meio ambiente;

22. Percebe a crise ambiental enquanto uma crise ética e cultural (da razão);

23. Compreende que o processo de construção do conhecimento leva à emancipação coletiva ou individual;

24. Sabe discernir, contextualizar e priorizar as estratégias de ação; 
25. Intervém no mundo de forma pró-ativa;

26. Sabe observar a prática do educador/educando;

27. Trabalha valores como a confiança, a cooperação e o respeito;

28. Busca, constantemente, novos conhecimentos;

29. Busca interlocutores para estabelecer diálogos em torno da Educação Ambiental;

30. Pesquisa, estimula e participa da criação de comunidades de aprendizagem;

31. Se enxerga como educador e educando;

32. Fomenta e participa dos processos de construção das políticas públicas;

33. Percebe os vários níveis de realidade;

34. Sabe trabalhas com/a afetividade;

35. Compreende a interdependência universal;

36. Não abandona as suas bandeiras só porque elas foram apropriadas pelo sistema. Pelo contrário, luta por mantê-las de acordo com os seus ideais;

37. Sabe ouvir e crescer com as críticas;

38. Sabe avaliar constantemente;

39. Procura se utilizar das diferentes linguagens nos processos de ensino aprendizagem;

40. Participa e fomenta a criação de processos democrático-circulares; 


\section{Anexo F}

\section{Avaliação da comunicação à distância no período de 10/09 a 20/10}

(Desconsideramos o período de 21/10 a 26/10 devido aos problemas técnicos decorrentes da queda de um raio na ESALQ)

1)Você pode afimar que no período de 10/09 a 20/10 acessou o CiberFórum:

a) entre 1 e 10 vezes

b) entre 11 e 20 vezes

c) entre 21 e 30 vezes

d) acima de 31 vezes

e) nenhuma vez

2) Descreva rapidamente que atividades você desenvolveu quando acessou o CiberFórum:

3) Como você considera a sua facilidade de comunicação no meio eletrônico?

a) Praticamente nula, não acessei

b) Ainda é "tímida"

c) Melhor nos momentos assíncronos

d) Melhor nos momentos síncronos

e) Independente dos momentos, é sempre boa

Por que? (Problemas com a gestão do tempo, ou com a máquina, ferramenta....)

Quanto ao Ciberfórum você pode afirmar que:

4) O acesso, de maneira geral, foi fácil? Sim Não Por que?

5) A compreensão do funcionamento e utilização dos recursos (conferência, chat, tópicos, pager) foi satisfatória? Sim Não Por que?

Quanto as conferências, você considera que:

6) Foram úteis para o seu aproveitamento (teórico) e relacionamento no curso? Sim Não

Por que?

7) Os alunos e alunas utilizaram adequadamente? Sim Não

Por que?

8) A coordenação do curso utilizou adequadamente? Sim Não Por que?

9) Houve facilidade para realizar as atividades propostas (em relação ao tempo, compreensão...)? Sim Não Por que?

10) Quanto aos dois chats organizados, que comentários você faria quanto a:

- sua participação,

- do grupo,

- da coordenação, e os

- assuntos discutidos.

Obrigada, Sandra 
Anexo G
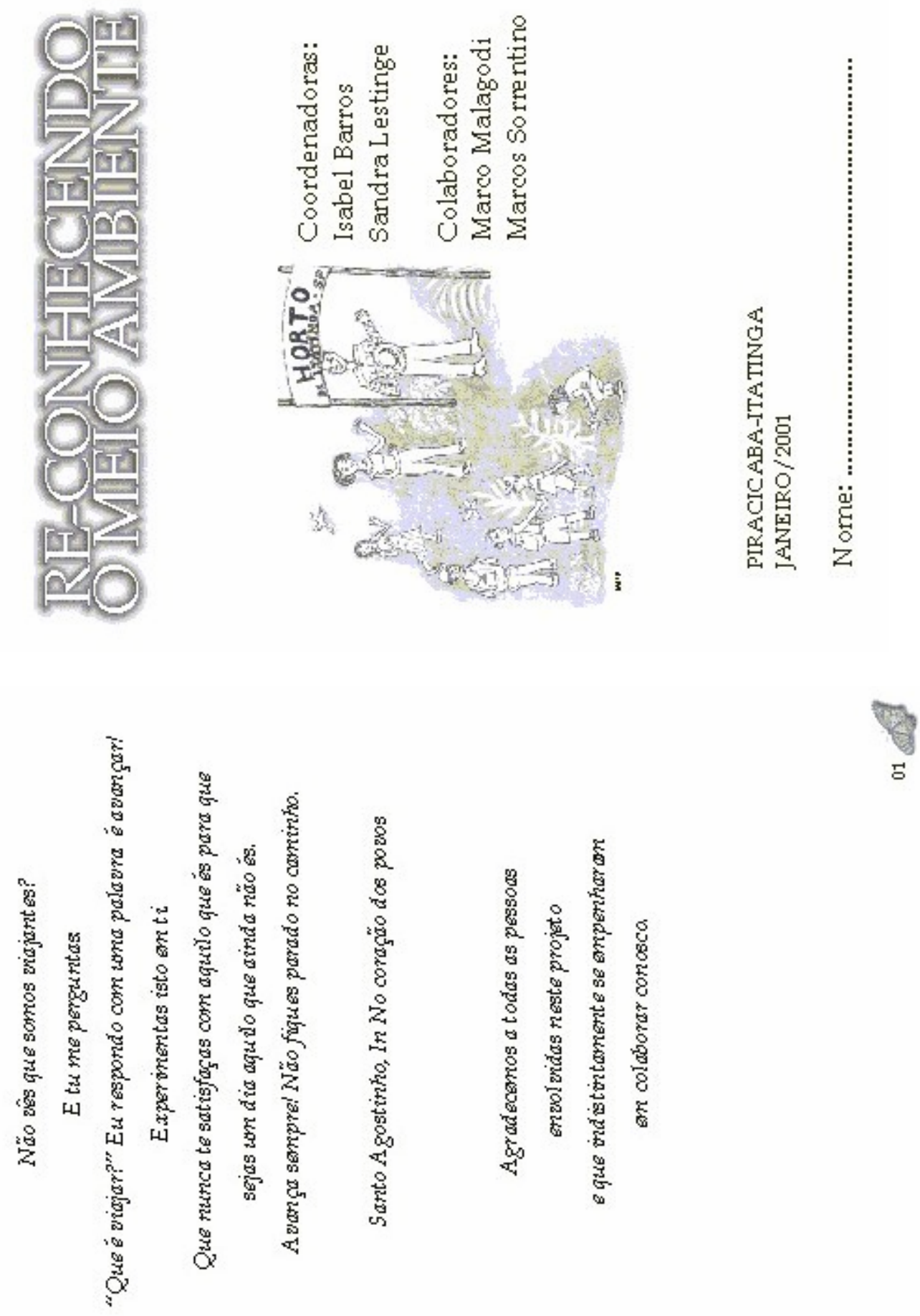

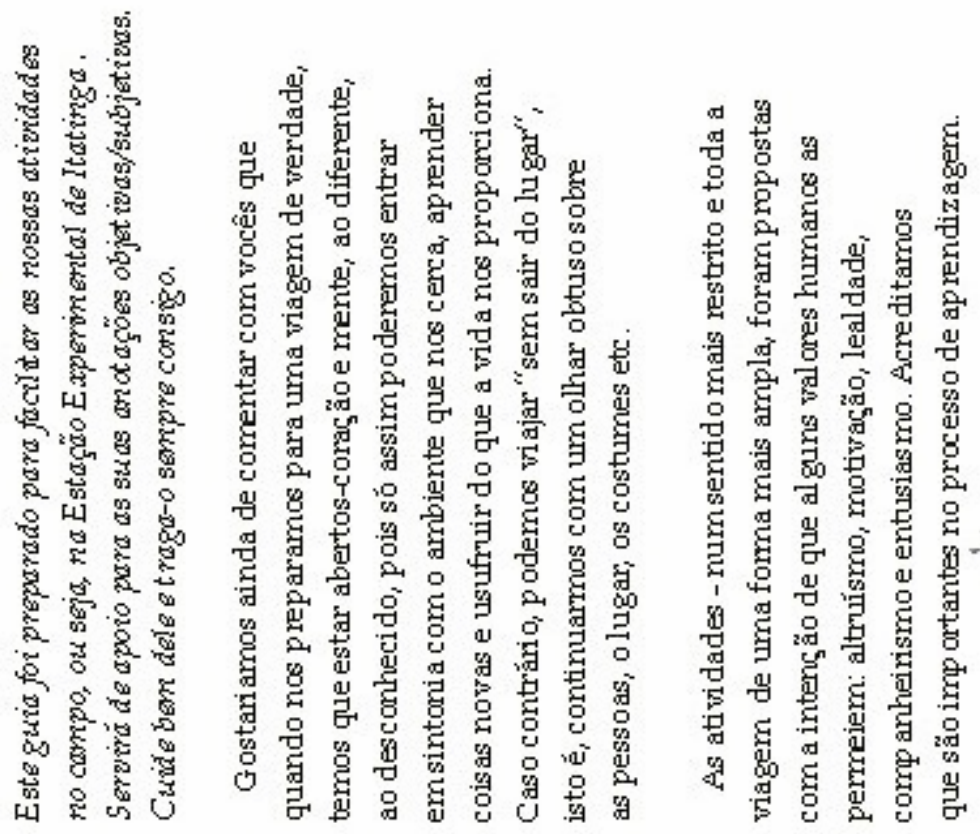

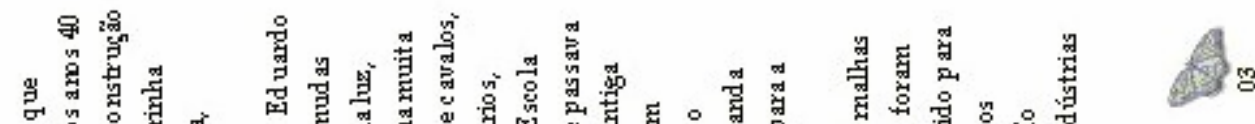

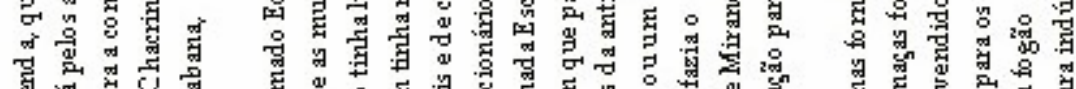

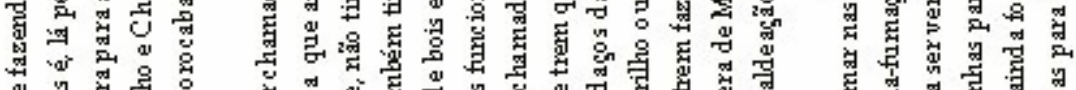

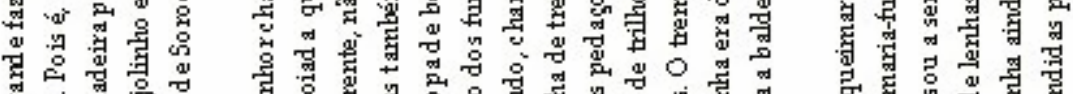

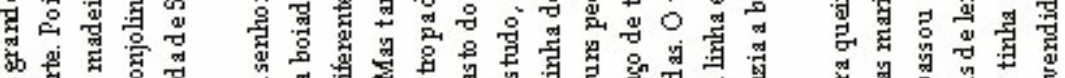

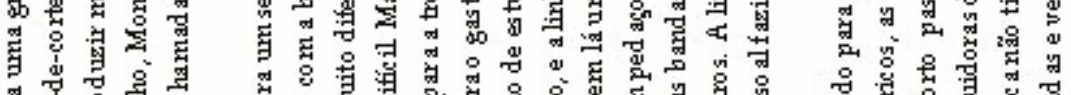

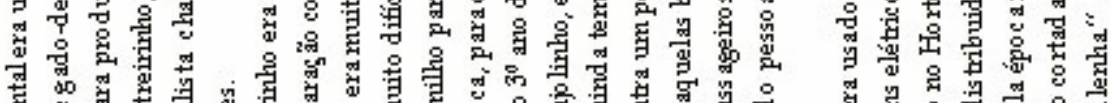

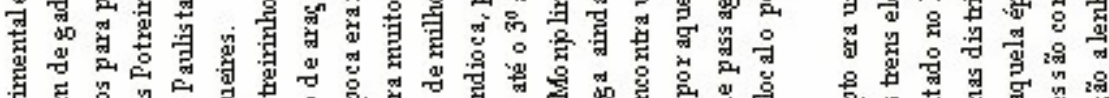

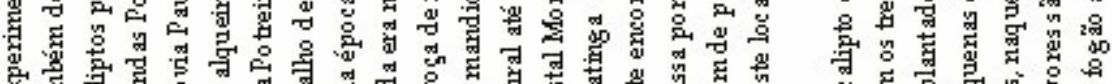

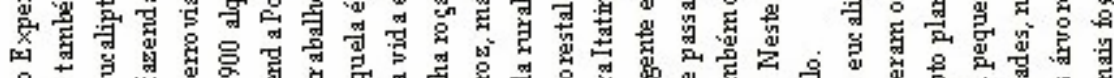

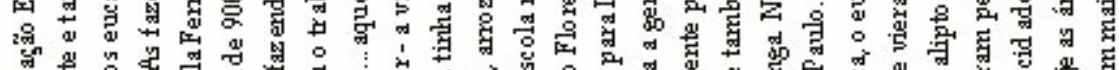

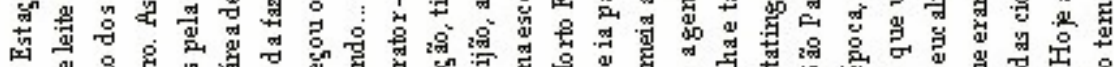

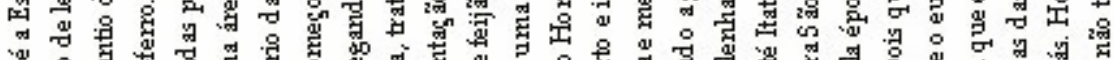

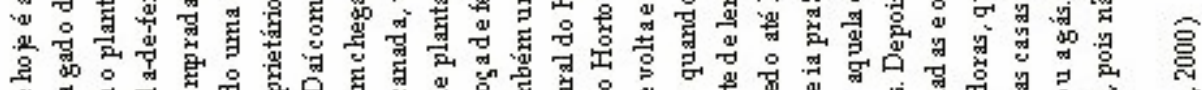

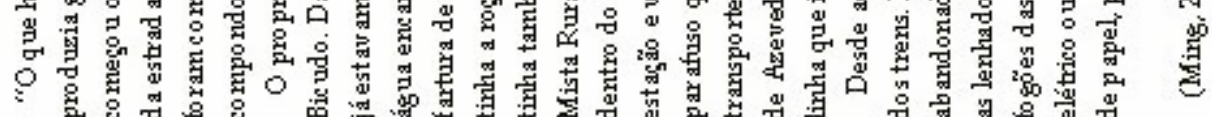



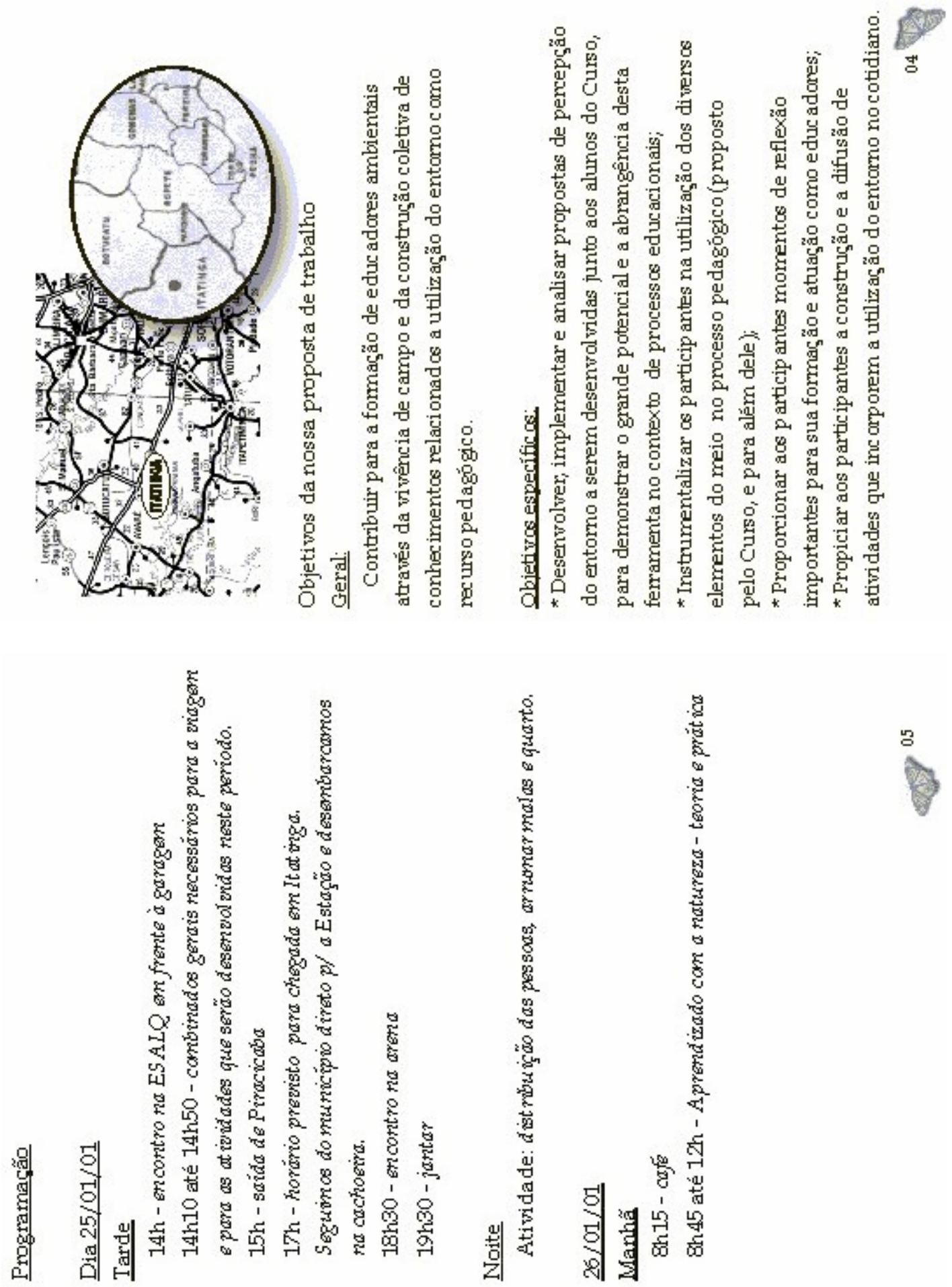

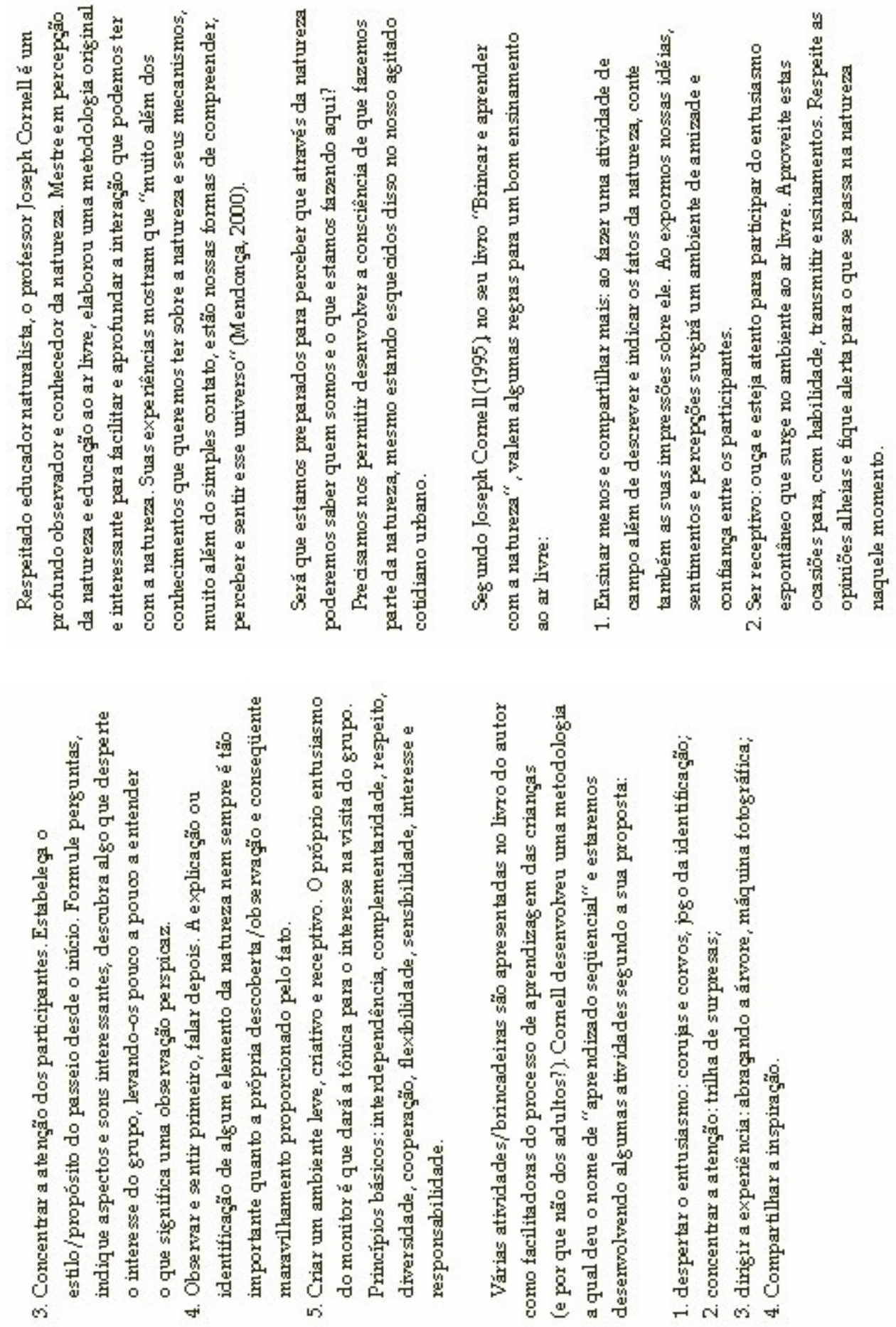

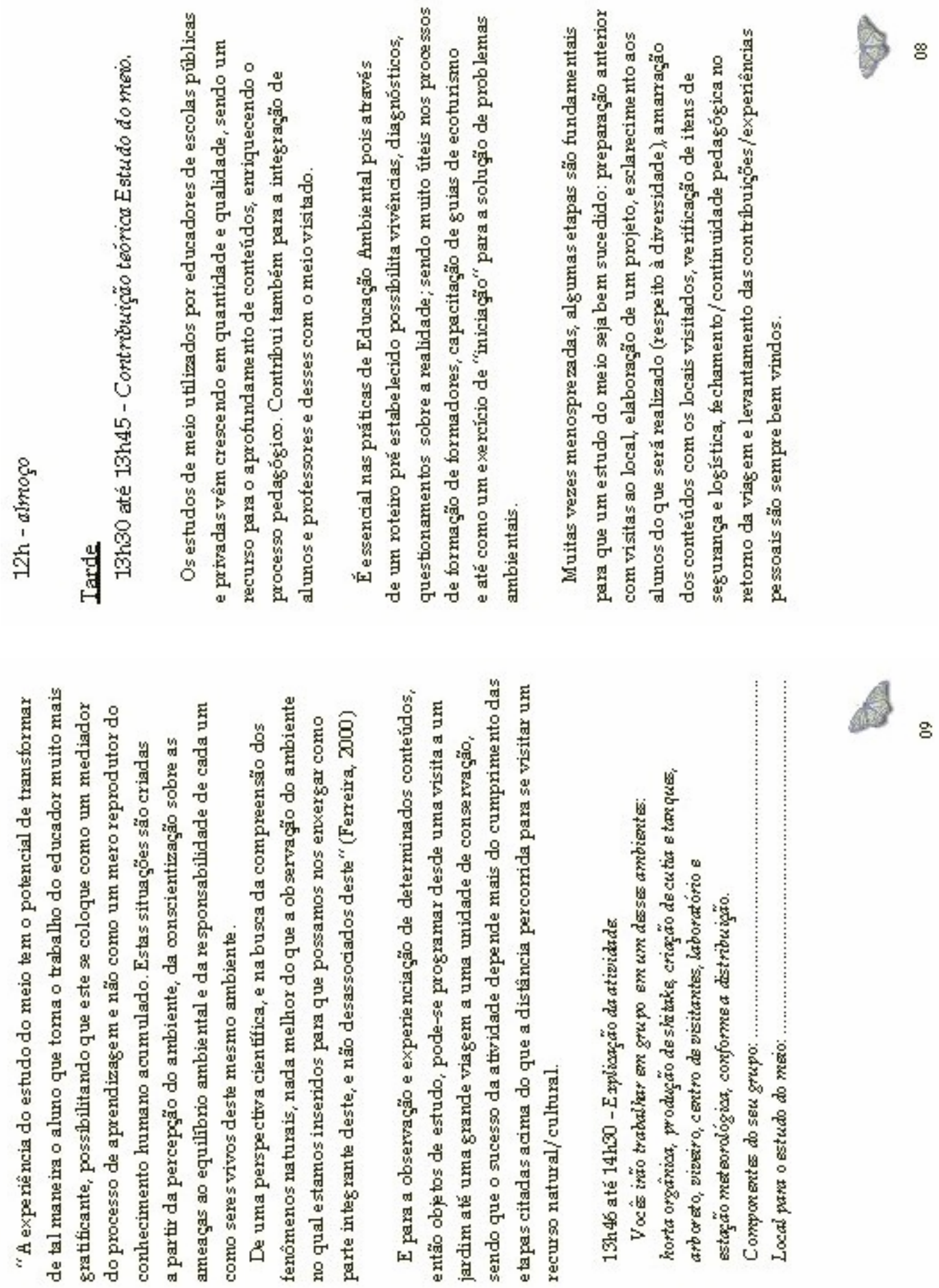

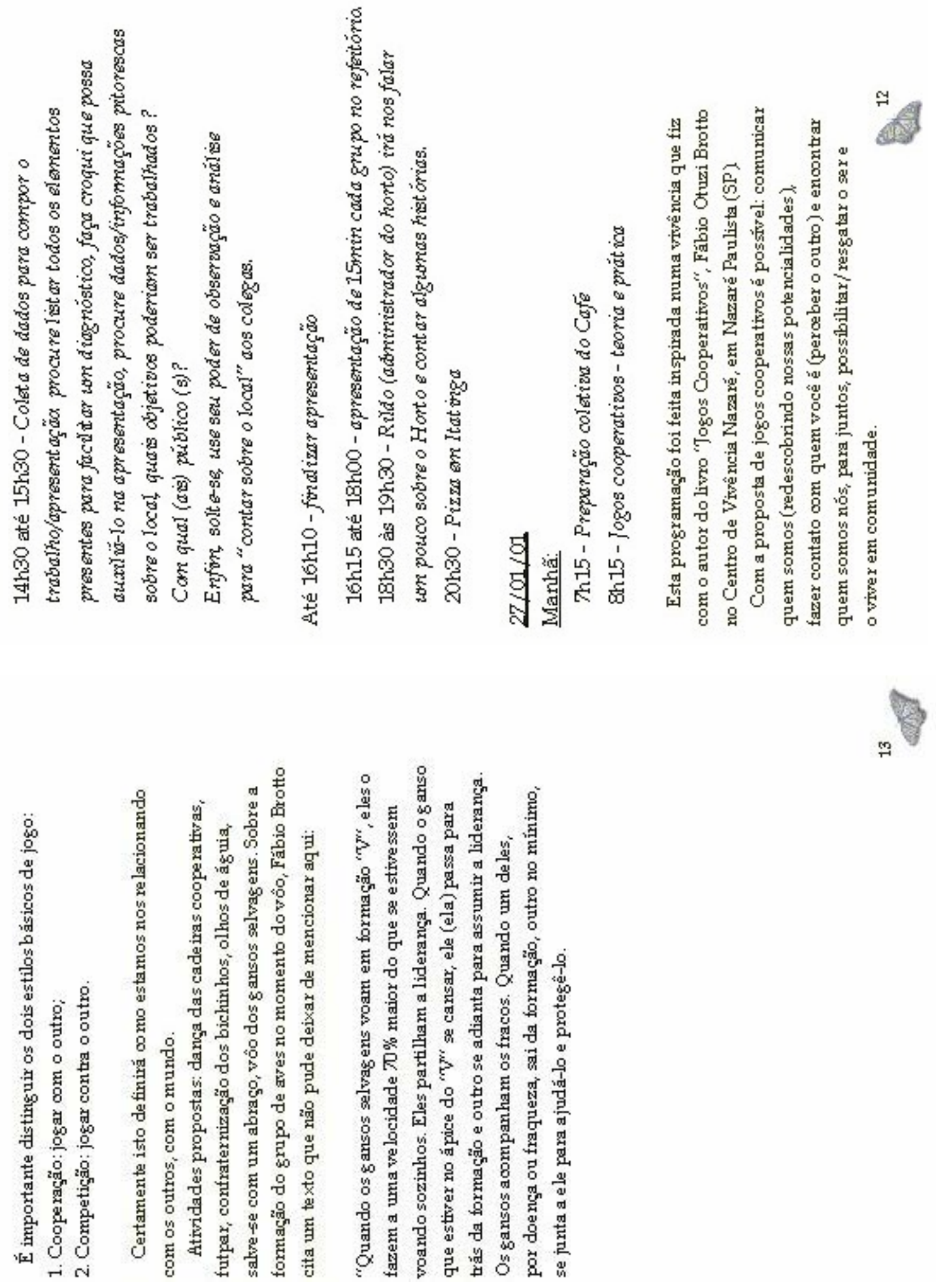

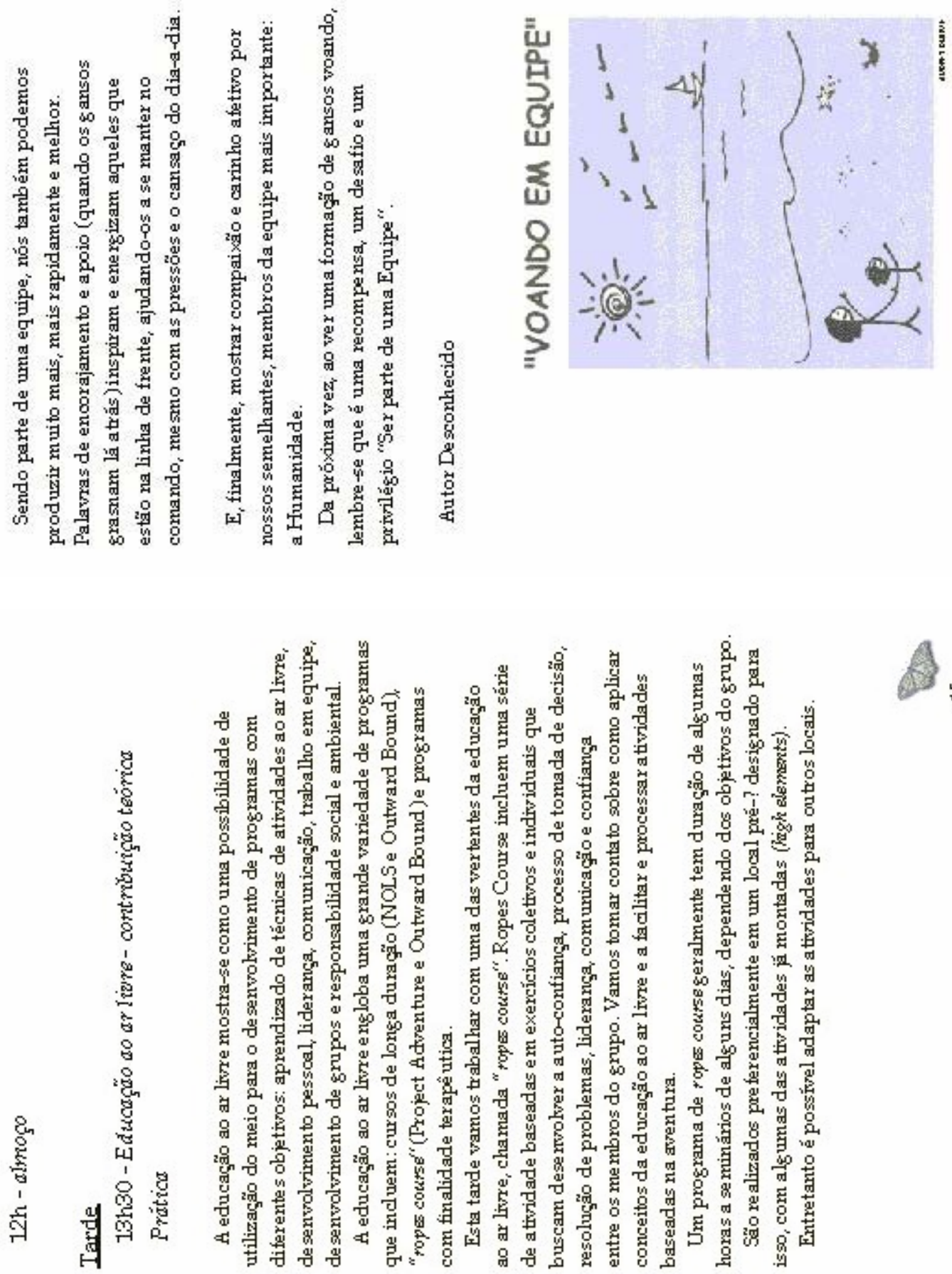

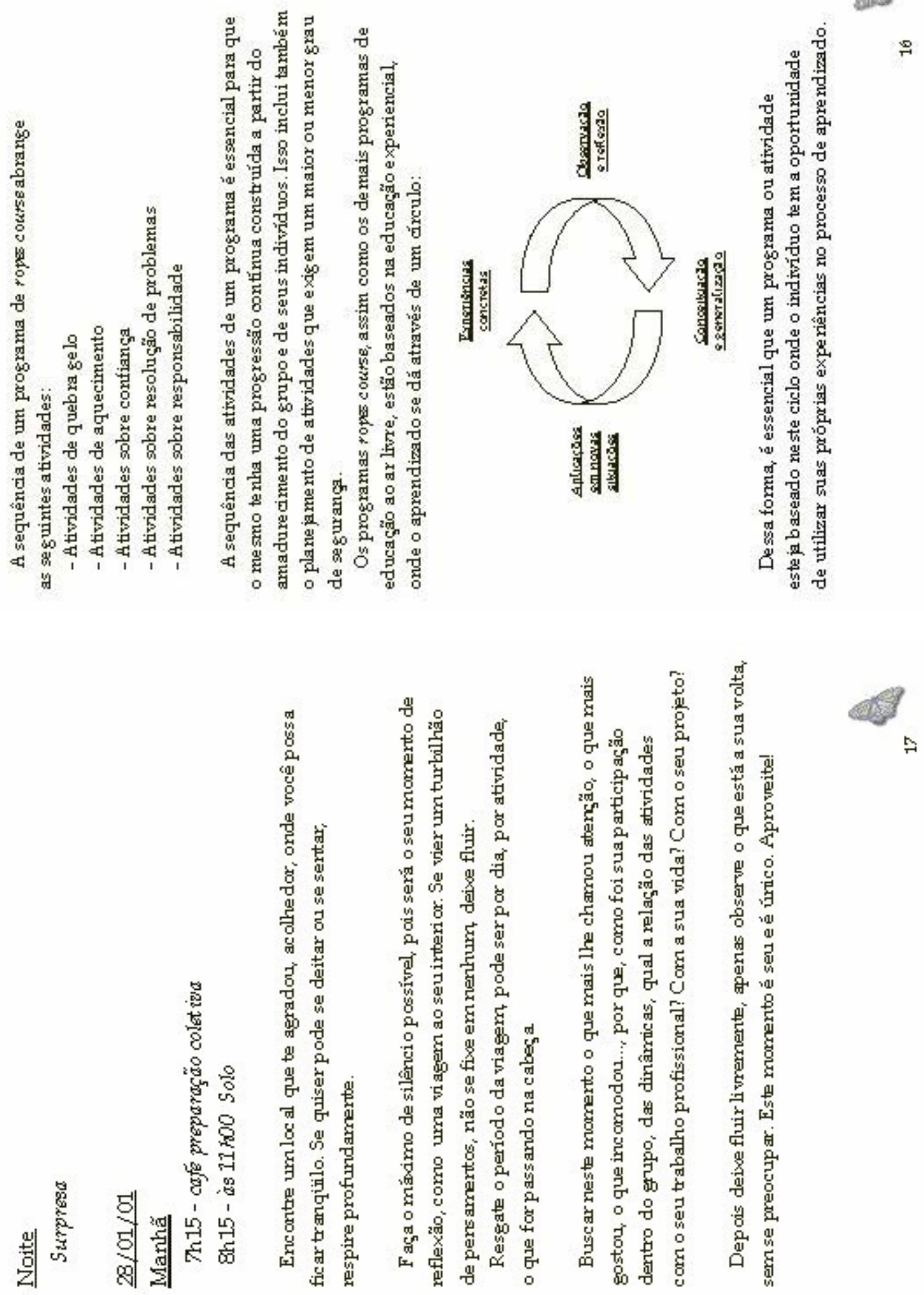

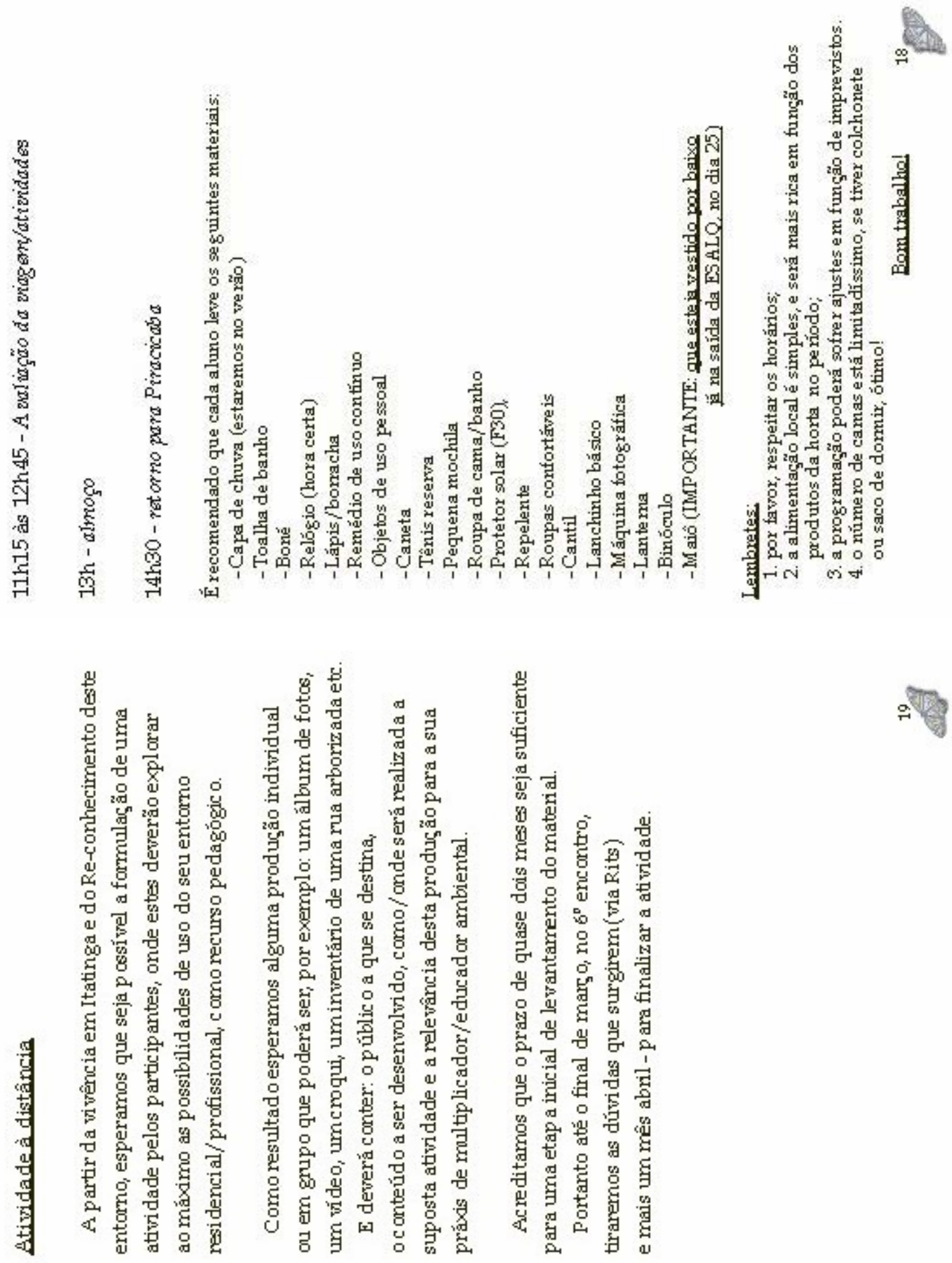


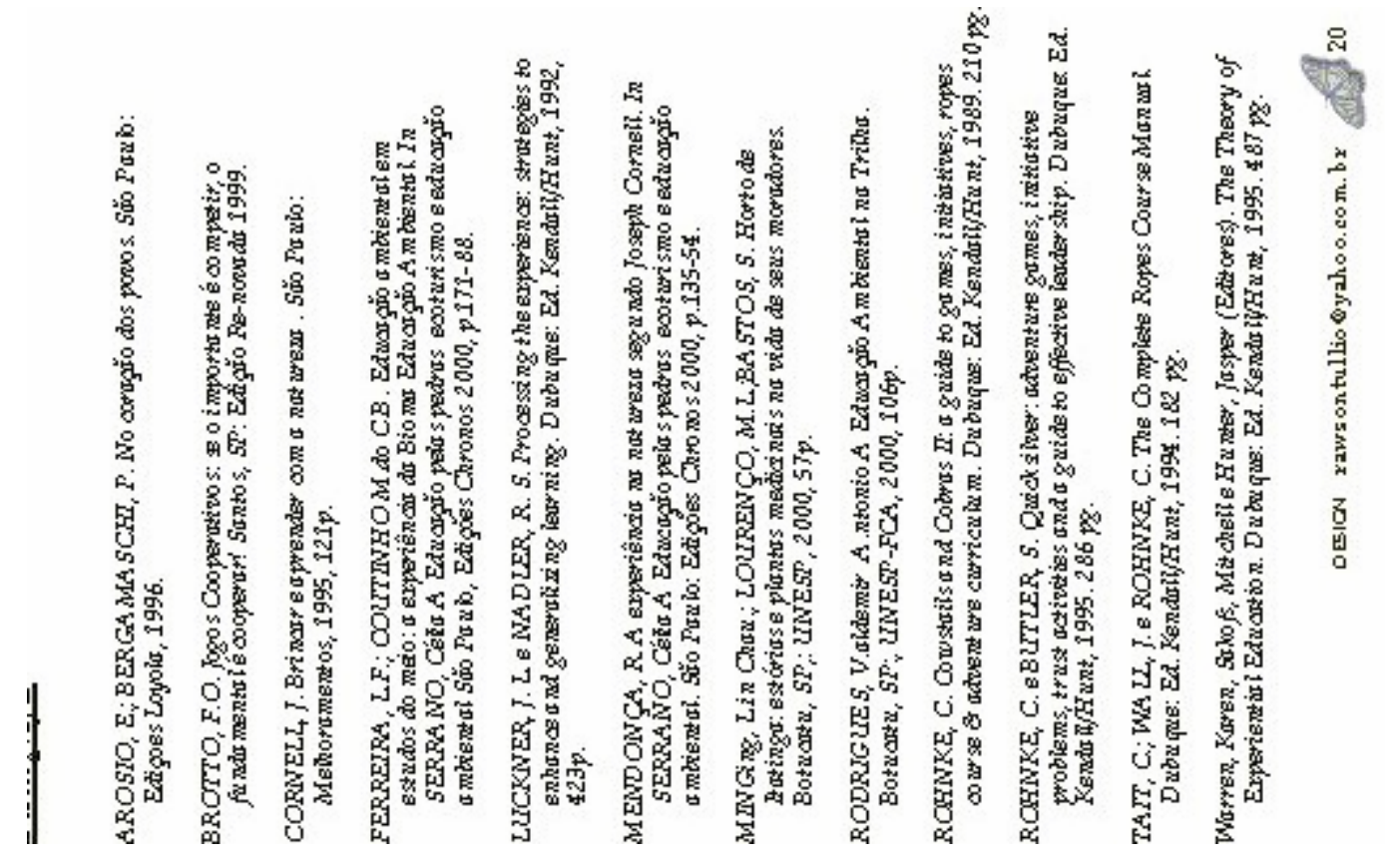




\begin{abstract}
ANEXO H
Itatinga, 28 de janeiro de 2001

Roteiro para avaliação da disciplina "Re-conhecendo o meio ambiente"

Por favor, para cada item abaixo, opte por "bom, ruim ou razoável", acrescentando/ descrevendo o por que da sua escolha e o que (e como) neste item poderá ser melhorado, contribuindo assim com o seu ponto de vista para o nosso trabalho. Caso sinta necessidade, pode acrescentar algum outro item ou comentário, além desses:
\end{abstract}

Preparação (etapa anterior à viagem): bom ruim razoável Porque:

Melhoria:

Atividades do dia 25:

Viagem

bom ruim razoável

Porque:

Melhoria:

Local escolhido bom ruim razoável

Porque:

Melhoria:

Cachoeira bom ruim razoável

Porque:

Melhoria:

Roda na fogueira bom ruim razoável

Porque:

Melhoria:

Noite

bom ruim razoável

Porque:

Melhoria:

Atividades do dia 26:

Aprendizado com a natureza bom ruim razoável

Porque:

Melhoria:

Estudo do meio

bom ruim razoável

Porque:

Melhoria:

Rildo/palestra

bom ruim razoável

Porque:

Melhoria:

Noitelavaliação

Porque:

bom ruim razoável

Melhoria: 
Pizza

Porque:

Melhoria:

Atividades do dia 27:

Preparação do café

Porque:

Melhoria:

Jogos cooperativos

Porque:

Melhoria:

Educação ao ar livre

Porque:

Melhoria:

Noite/surpresa/sanfona

Porque:

Melhoria:

Atividades do dia 28:

Café da manhã

Porque:

Melhoria:

Solo

Porque:

Melhoria:

Avaliação

Porque:

Melhoria: bom ruim razoável

bom ruim razoável

bom ruim razoável

bom ruim razoável

bom ruim razoável

bom ruim razoável

bom ruim razoável

bom ruim razoável

Gostaríamos ainda de saber, com relação a todos os encontros presenciais do curso de especialização, se houve alguma atividade em especial que contribuiu para a sua percepção e aprendizagem sobre o meio ambiente? Qual foi?

Obrigado(a). 


\begin{abstract}
ANEXO I
Questionário I

Olá! Gostaria que respondesse as seguintes questões, na ordem em que elas se apresentam. O tempo médio estimado que irá gastar é de 30 minutos.
\end{abstract}

1. Você tem participado de alguma atividade (aulas, cursos, profissional dia-a-dia etc) como Educador Ambiental?

2. Pretende continuar a participar neste ou no próximo ano? Ou vir a participar?

3. Explique melhor qual ou quais são estas atividades.

4. Qual/quais tema/temas tem trabalhado?

5. Descreva qual é o público (quem, quantos.... ).

6. Duração da atividade?

7. Tem utilizado Estudo do Meio ?

8. Por quê?

9. Onde foi, como foi?

10. Quais conceitos importantes dentro do ambientalismo, têm sido desenvolvidos/usados com seu público?

11. Como os EM poderão/puderam ajudá-lo/a a trabalhar/desenvolver estes conceitos?

12. O que significa para você:

- Estudo do Meio

- Interpretação da paisagem

- Percepção ambiental

- Estímulo dos sentidos

- Meio ambiente

- Pertencimento

- Inserção do sujeito no meio ambiente

- Participação

- Entorno

(E outras que o aluno citar nas questões acima)

Em que medida o curso de especialização, e as atividades nele desenvolvidas, foram úteis para estas compressões?

13. O que vc acha da utilização do EM para a compreensão desses conceitos? 14. E para o ensino-aprendizagem?

Há outros comentários que gostaria de fazer?

Você está disposto (a) a continuar a contribuir com esta pesquisa? 


\section{Anexo J}

Piracicaba, 24 de setembro de 2001

Assunto: Carta de intenção

Prezados Colegas,

Desenvolvi junto ao Curso de especialização "Formação de Educadores Ambientais para Sociedades Sustentáveis" uma primeira etapa da pesquisa de mestrado que teve como tema central o Estudo do Meio.

Continuando com esse estudo, agora numa segunda etapa em nível de doutorado, encaminho esta carta no sentido de iniciar um diálogo com cada um, a fim de sabermos como o Estudo do Meio está fazendo parte das atividades desenvolvidas por vocês.

Gostaria de agendar uma conversa que poderá ser por e-mail, presencial ou telefone.

Garanto o sigilo das informações fornecidas por vocês e que terão a identidade resguardada. Os dados obtidos serão utilizados enquanto categorias analíticas, para efeito de pesquisa.

Os dados obtidos na primeira etapa estão sendo sistematizados, e assim que possível, estarão sendo apresentados para vocês.

Aguardo uma resposta afirmativa, o mais breve possível, a fim de poder iniciar mais uma etapa de coleta de dados.

Agradeço a atenção,

Sandra Lestinge

ambiental@ig.com.br

Fone: (19) 434-3607 


\section{Anexo K}

Olá queridos e saudosos colegas...

Faço fé de que tenham passado esses dias de festas com alegria e grandes comemorações/renovações!

Bem, como era de se esperar, no ano novo que se inicia, temos alguns trabalhos a concluir e outros a recomeçar.

Após minha qualificação, tive algumas sugestões da banca e gostaria de contar com vocês para terminar um trabalho com oito dos egressos: Fernando, Claudia, Costa, Eliane, Fabíola, Noeli, Pathie e Sandra.

Este email é para nos "sintonizarmos": saber se os endereços/telefones estão funcionando, etc. Assim que eu tiver esta etapa pronta (metodologicamente) entro em contato de novo com vocês (por tel e/ou email) para contar como será realizada.

Gostaria que respondessem esse email atualizando, se for o caso, o telefone e/ou endereço e me dizendo se final de janeiro e fevereiro estarão em casa ou "próximos" a Piracicaba.

Um forte abraço,

Bom 2004!

Agradeço a atenção,

Sandra Lestinge

08/01/2004 


\section{Anexo L}

Roteiro para leitura das transcrições dos egressos do curso de especialização.

Etapa final

Olá!

Você está recebendo um "lote" que contém 4 materiais que foram coletados ao longo deste projeto de pesquisa (de 2000 a 2003), e do qual você é parte essencial. Nos anexos você encontrará:

* o "ponto zero" (primeiro questionário do primeiro encontro presencial)

* "Itatinga 1" (rodada final, perguntamos qual as contribuições pessoais/profissionais da disciplina em Itatinga);

* "entrevista semi-estruturada" (fizemos no local...) e o

* "acompanhamento in loco" (local).

E alguns comentários/observações minhas no meio...

Finalizando os trabalhos de campo, solicitamos que:

* leia atentamente cada transcrição, na seqüência em que se apresentam;

* tente recordar-se de como você estava no momento em cada coleta foi realizada;

* faça as correções que julgar necessárias: incorreções de transcrição e de interpretação da pesquisadora e/ou mudanças de opinião considerando seu modo de pensar/agir de hoje;

* considere que alguns trechos considerados irrelevantes para essa pesquisa foram desconsiderados

* Considere EM como estudo do meio; EA como educação ambiental;MA como meio ambiente e não repare nas abreviações (vc, qq, pq) ou erros de digitação.

* Importante: por favor, ao final das leituras faça - em uma página - uma síntese de tudo isso. Se tivesse que fazer um resumo de tudo isso, como ele ficaria? Nós iremos utilizar esse material no reencontro.

Se tiver alguma dúvida, por favor, me diga.

Muito obrigada por tudo,

Um abraço,

Sandra Lestinge 


\section{Anexo M}

\section{$5^{\circ}$ encontro (03/05/2001) - Coversando sobre o Estudo do Mejo}

\section{Rural - LOCal: ESALQ}

\section{Objetivo do encontro}

Resgatar e socializar as informações obtidas na atividade de estudo do meio, discutindo suas potencialidades como recurso didático para uma compreensão ambiental reflexiva.

\section{Descrição das atividades}

- Dinâmica de relaxamento para favorecer a concentração das participantes.

- Registro e socialização das informações obtidas na atividade de estudo do meio.

- Sistematização dos dados levantados sobre as regiões abrangidas pela escola.

- trabalho em grupo (dividindo as participantes segundo as escolas que trabalham) para resgatar os dados recolhidos individualmente na tarefa solicitada no 30 encontro.

- construção, sobre uma foto aérea, de uma representação da realidade da região abrangida pela escola.

- apresentação dos trabalhos do grupos.

- Debate: Estudo do Meio Rural, com a mestranda Sandra Lestinge (ESALQ/USP) (anexo-transcriçãoIII).

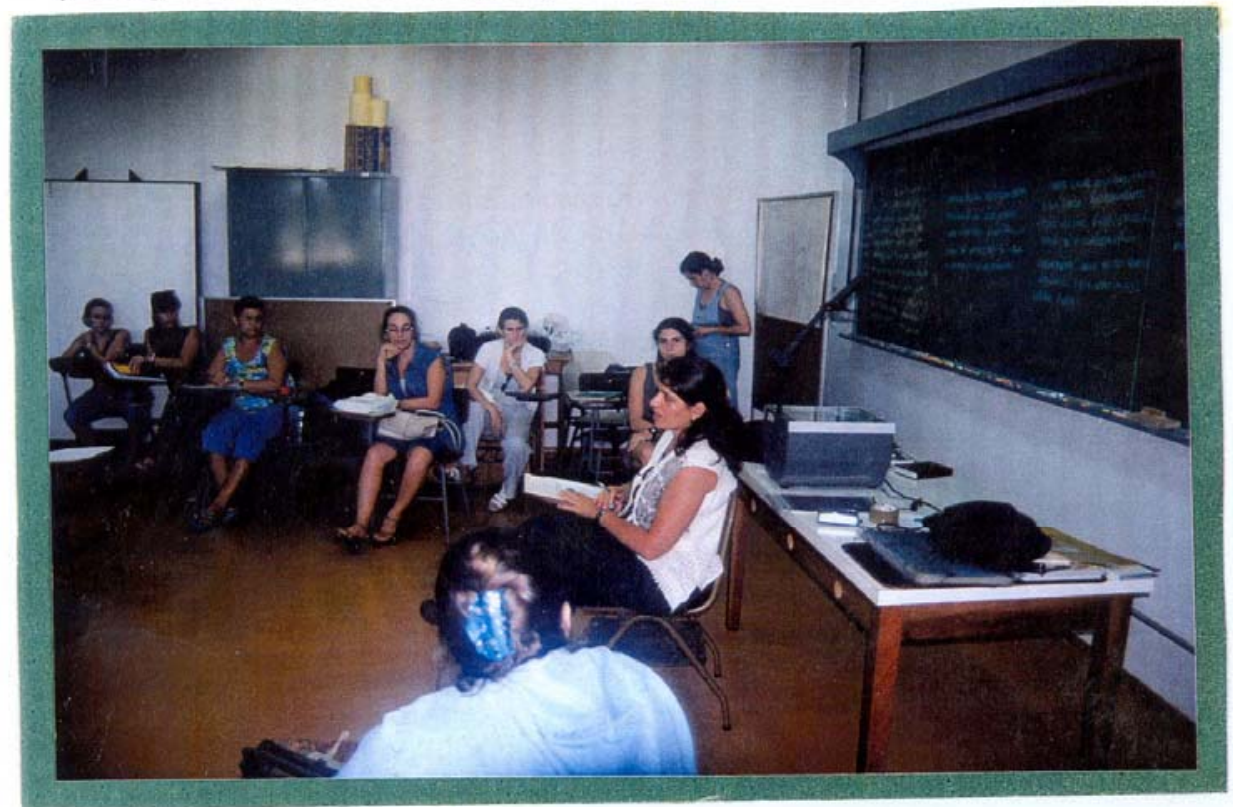

Acima, a convidada Sandra Lestinge coordena a socializaçăo das informações, percepções e reflexões da atividade do estudo do meio (encontro anterior).

A foto da página seguinte mostra as professoras preparando (em grupo) a transparência com a foto aérea que foi, em seguida, apresentada ao grupăo através de um retroprojetor. 


\section{REFERÊNCIAS BIBLIOGRÁFICAS}

ALLAL, L; CARDINET, J.; PERRENOUD, P. À avaliação formativa no ensino diferenciado. Coimbra: Livraria Almedina, 1991. 212p.

ANDRÉ, M.E.D.A Tendências atuais da pesquisa na escola. Cadernos Cedes, v.18, n.43, p.46-57, dez.1997.

BACHELAR, G. A poética do devaneio. São Paulo: Martins Fontes, 1988. 205p.

BACHELAR, G. A água e os sonhos: ensaio sobre a imaginação da matéria. São Paulo: Martins Fontes, 1989. 202p.

BAPTISTA, I. Educação e Memória. http://www.apagina.pt/arquivo/Artigo.asp?ID=617 (10 maio 2004).

BARBIER, R. Pesquisa-ação na instituição educativa. Rio de Janeiro: Jorge Zahar Editor, 1985. 280p.

BARBOSA, J. (Org.) Reflexões em torno da abordagem multirreferencial. São Carlos: Editora da UFSCar, 1998a. 126p.

BARBOSA, J. (Coord.). Multirreferencialidade nas ciências e na educação. São Carlos: Editora da UFSCar, 1998b. 126p.

BARREIRA, M.C.R.N. Avaliação participativa de programas sociais. São Paulo: Veras Editora-CPIHTS, 2002. 134p. 
BAUER, M.W.; GASKELL, G. Pesquisa qualitativa com texto, imagem e som: um manual prático. Petrópolis: Editora Vozes, 2003. 516p.

BECKER, H.S. Métodos de pesquisa em ciências sociais. 4.ed. São Paulo: Hucitec, 1999.178p.

BELLONI, M.L. Educação a distância. Campinas/SP: Autores Associados, 2001. 115p.

BERMAN, M. Tudo que é sólido desmancha no ar. São Paulo: Companhia das Letras, 1987. P. $10-35$

BOFF, L. Tempo de transcendência: o ser humano como um projeto infinito. Rio de Janeiro : Sextante, 2000. 93p.

BONDÍA, J. L. Notas sobre a experiência e o saber de experiência. Campinas: Leituras SME, n. 4, jul. 2001. 10p

BORDA, O.F. Aspectos teóricos da pesquisa participante: considerações sobre o significado e o papel da ciência na participação popular. In: BRANDÃO, C.R. Pesquisa participante. 8.ed. São Paulo: Brasiliense, 1999. p.42-62.

BRADLEY, M.Z. As brumas de Avalon. Rio de Janeiro: Imago, 1989. 4v.

BRANCO, S.M. Expedição ecológica ao fundo do quintal. São Paulo: CETESB, 1984. 62p.

BRANDÃO, C.R. O ambiente, o sentimento e o pensamento: dez rascunhos de idéias para pensar as relações entre eles e o trabalho do educador ambiental. In: FÓRUM DE EDUCAÇÃO AMBIENTAL, 4.,1997, Rio de Janeiro, 1997.17-38p.

BRANDÃO, C.R. Pesquisa participante. 8.ed. São Paulo: Brasiliense, 1999a. 212p. 
BRANDÃO, C.R. Re-pensando a pesquisa participante. 8.ed. São Paulo: Brasiliense, 1999b. 212p.

BROTTO, F. Jogos cooperativos: se o importante é competir o fundamental é cooperar! Santos: Edição Re-novada. 1999, 176p.

CALVINO, I. O modelo dos modelos In CALVINO, I. As férias de palomar. São Paulo: Companhia das Letras, 1990. 122p. p. $97-100$

CAPRA, F. O ponto de mutação. São Paulo: Cultrix, 1982. 444p.

CAPRA, F. A teia da vida - uma nova compreensão científica dos sistemas vivos. São Paulo: Cultrix, 1996. 256p.

CARVALHO, I. Los sentidos de lo "ambiental": la contribuición de la hermenéutica a la pedagogía de la complejidad. In: LEFF, E. (Org.) La complejidad ambiental. México: Siglo Veintiuno Ed., 2000. 85-105p.

CARVALHO, I. Qual educação ambiental? Elementos para um debate sobre educação ambiental popular e extensão rural. In Anais do I simpósio sul brasileiro de educação ambiental Erechim: EdicaFAPES, 2002.

CELESTE, M. F. Fragmentos de educação ambiental e cidadania. In: SORRENTINO, M., TRAJBER, R. e BRAGA, T., FÓRUM DE EDUCAÇÃO AMBIENTAL. São Paulo, SP, 1995, CADERNOS São Paulo: Gaia, 1995.

CORNELL, J. A alegria de aprender com a natureza. São Paulo: Melhoramentos. 1995, 186p.

CORNELL, J. Brincar e aprender com a natureza. São Paulo: Melhoramentos, 1997. $121 p$. 
CRITELLI, D.M. Todos nós...ninguém: um enfoque fenomenológico do social. São Paulo: Editora Moraes. 1981. 72p.

CULTURA E DESENVOLVIMENTO RURAL. Promover a cultura local: a experiência de lochaber. http://europa.eu.int/comm/archives/leader2/rural-pt/biblio/culture/ art07 (15 maio 2004)

DALLARI, D. Direito de participação. In: SORRENTINO, M. (Org.) Ambientalismo e participação na contemporaneidade. São Paulo: Ed. EDUC, 2001, p.85-114.

DARWIN, C. Origem das espécies. Belo Horizonte: Ed. Itatiaia; São Paulo: Ed.USP, 1985. 366p.

DEBESSE-ARVISET M. L. El entorno en la escuela: una revolución pedagógica: Didática de la geografia. 3. ed. México: Ediciones Roca, 1985. 184p.

DELORS, J. Educação: um tesouro a descobrir. 4ed. São Paulo: Cortez; Brasília, DF: MEC: UNESCO, 2000. 288p.

DEMO P. Avaliação qualitativa. 7.ed. Campinas, SP: Autores Associados, 2002. 109p.

EDUCAÇÃO http://www.mec.gov.br/sef/Ftp/LEI979599.doc (13 jun.2003)

ENCICLOPÉDIA DE FILOSOFIA. Nietzschegeocities.yahoo.com.br/mcrost07/nietzsche.htm -14k. (10 abr 2004).

EZPELETA, J.; ROCKWELL, E. Pesquisa participante. São Paulo: Cortez, 1986. 93p.

FERRARA, L. D'A. Olhar periférico. São Paulo: Edusp, 1999. 277p. 
FERREIRA, L.F.; COUTINHO, M. C. do B. Educação ambiental em estudos de meio: a experiência da bioma educação ambiental. A Educação pelas pedras: ecoturismo e educação ambiental. São Paulo: Chronos, 2000. 171-188p.

FERRY, L. A nova ordem ecológica: a árvore, o animal e o homem. São Paulo: Ensaio, 1994. p. 7-29, 167-193.

FÓRUM INTERNACIONAL DE ONG. Tratado de Educação Ambiental para Sociedades Sustentáveis Responsabilidade Global. Rio de Janeiro, 1992. http://www.geocities.com/cream_br/tratado.htm (13 mar 2003).

FOUCAULT, M. A verdade e as formas jurídicas. Rio de Janeiro: Nau editora, 1999. $158 \mathrm{p}$.

FREIRE,P. Extensão ou comunicação? Rio de Janeiro : Paz e Terra, 1977. 93p.

FREIRE,P. Pedagogia da esperança.. Rio de Janeiro : Paz e Terra, 1992. 245p.

FREIRE,P. Pedagogia da autonomia.. São Paulo: Paz e Terra, 2000. 165p.

FREITAS, L.; MORIN, E.; NICOLESCU, B. Carta da transdisciplinaridade. Portugal, 1994. http://www.humanas.unisinos.br/curriculo/professores/candido/textos/carta.doc (10 maio 2004).

GARAUDY, R. Apelo aos vivos. Rio de Janeiro: Nova Fronteira, 1981. p.11-73.

GIANNETTI, E. Felicidade. São Paulo: Companhia das letras, 2002. 226p.

GOETHE, J. W. Viagem à Itália. São Paulo: Companhia das Letras, 1999. 440p.

GONÇALVES, C.W.P. Meio ambiente, ciência e poder: diálogo de diferentes matrizes de racionalidade. In: SORRENTINO, M. Ambientalismo e participação na contemporaneidade. São Paulo: Ed. EDUC, 2001, p.135-161. 
GOODLAND, R.J.A.; IRWIN, H.S. A selva amazônica: do inferno verde ao deserto vermelho. São Paulo: ed. Itatiaia- Universidade de São Paulo, 1975. 156 p.

GORMLEY, K. J. Diálogo entre pesquisadores "acadêmicos" e "comunitários": As possibilidades e desafios da pesquisa participante http://www.paulofreire.org/convergence.pdf (10 jul. 2003).

GUATTARI, F. As três ecologias. Campinas: Papirus. 2000. 56p.

GUITIÉRREZ, F. Educação como práxis política. São Paulo: Summus editorial, 1988. $125 p$.

GUITIÉRREZ, F. Ecopedagogia e cidadania planetária. São Paulo: Cortez Editora, 1999. 128p.

HEIDEGGER, M. Sobre o problema do ser. O caminho do campo. São Paulo: Livraria duas cidades, 1969. 72p.

HEIDEGGER, M. Todos nós...ninguém: um enfoque fenomenológico do social. São Paulo: Editora Moraes. 1981. 72p.

HOEHNE.F.C. Programa instructivo e educativo. Resenha Histórica, p.67-82, abr 1937.

KÜGELGEN, v. H. A educação waldorf - aspectos da prática pedagógica. São Paulo: Editora Antroposófica, 1984. 83p.

LAVILLE, C.; DIONNE, J. A construção do saber - manual de metodologia da pesquisa em ciências humanas. Porto Alegre: Artmed; Minas Gerais: Editora UFMG, 1999. 340p.

LEE, T. Psicologia e meio ambiente. Rio de Janeiro: Zahar Editores, 1977. 159p. 
Lei de Diretrizes e Bases - LDB http://www.pr.gov.br/cee/ceeldb.html (05 maio 2003).

LEFF, E. Epistemologia ambiental. São Paulo: Cortez Editora. 2001. 240p.

LESTINGE, S.; ROSSI, F. Educação ao ar livre como auxílio à prática pedagógica (material apostilado).

LOBO, V. Guia do escoteiro. 2.ed. Rio de Janeiro: Imprensa, 1932. 496p.

LÜDKE,M.E.; ANDRÉ, M.E.D.A. Pesquisa em educação: abordagens qualitativas. São Paulo: Editora Pedagógica e Universitária, 2001. 99p.

MACHADO, N.J. Sobre a idéia de projeto in MACHADO, N.J. Ensaios Transversais: cidadania e educação. São Paulo: Editora Escritoras, 1997. p 63-68.

MAILHIOT, G.B. Dinâmica e gênese dos grupos. São Paulo: Livraria duas Cidades, 1991.188p.

MALTA, C.; CONDE, M. G.C.; DIALETACHI, S. Elaboração de projetos em meio ambiente. São Paulo: Gaia. Coleção Gaia - Ecoar, 1995. p.235-239.

MCCORMICK, J. Rumo ao paraíso: a história do movimento ambientalista. Rio de Janeiro: Relume-Dumará, 1992. p 7- 41.

MENDONÇA, R. A experiência na natureza segundo Joseph Cornell. In: SERRANO, C. (org) A Educação pelas pedras: ecoturismo e educação ambiental.São Paulo: Chronos, 2000. p.135-154.

MENDONÇA, R.; NEIMAN, Z. À sombra das árvores - transdisciplinaridade e educação ambiental em atividades extraclasse. São Paulo: Chronos, 2003. 123p.

MERLEAU-PONTY, M. Fenomenologia da percepção. São Paulo: Ed. Martins Fontes, 1999. 662p. 
MERLEAU-PONTY, M. O visível e o invisível. São Paulo:Editora perspectiva.2000. $271 p$.

MINAYO, M.C.S. Pesquisa social: teoria, método e criatividade. Petrópolis: Vozes, 1998. 80p.

MORIN, E.; KERN, A. B. Terra-pátria. Porto Alegre: Sulina, 1995. 189p.

MORIN, E. Os sete saberes necessários à educação do futuro. São Paulo: Editora Cortez, UNESCO, 2000, 115p.

MORIN, E. Educar na era planetária. São Paulo: Editora Cortez, UNESCO, 2003. $111 p$.

NEVES, A.; CUNHA FILHO, P. Projeto virtus: educação e interdisciplinaridade no ciberespaço. Recife: Editora Universitária da UFPE; São Paulo: Ed. Da Universidade Anhembi Morumi, 2000. 158.

NIDELCOFF, M.T. A escola e a compreensão da realidade. São Paulo: Ed. Brasiliense, 1979. 102p.

OKAMURA, C. Arouche 2004: uma incursão no território urbano da cidade de São Paulo através de seus personagens. São Paulo: USP. (Tese de doutorado). 2004. 300p.

ORLANDI, E.P. Discurso e leitura. São Paulo:Editora Cortez, Editora UNICAMP. 2000, $118 p$.

ORLANDI, E.P. Análise de discurso. Campinas: Pontes, 2002.100p.

OTT, M.B. Ensino por meio de solução de problemas. In: CANDAU, V.M. (org.). A didática em questão. Petrópolis: Vozes, 1989. 128p. 
Parâmetros curriculares nacionais: meio ambiente e saúde. Brasília: MEC/SEF,1997

PEGORARO, J. Atividades educativas fora da sala de aula em escolas da região de Campinas. Material apostilado, /2000?/.

PETRAGLIA, I.C. Complexidade e auto-ética. ECCOS Revista Científica Centro Universitário Nove de Julho, v.2, n.1, p.9-17, jun. 2000.

PITTENGER, O. E.; GOODING, C. T. Teorias da aprendizagem na prática educacional - uma integração de teoria psicológica e filosofia educacional. São Paulo: EPU - EDUSP, 1977. 208p.

PONTUSCHKA, N. N. A formação pedagógica do professor de geografia e as práticas interdisciplinares. São Paulo, 1994. 343p. Tese (Doutorado) - Faculdade de Educação, Universidade de São Paulo.

PONTUSCHKA, N. N. "O olhar da educação sobre o ambiente" Debates sócioambientais, CEDEC - Centro de Estudos de Cultura Contemporânea, v.3, n. 10, Jul/Out, 1998, p. 18-20.

RAIMO, F. de O. Aventura, aprendizagem e desenvolvimento pessoal. In: SERRANO, C. (org). A Educação pelas pedras: ecoturismo e educação ambiental.São Paulo: Chronos, 2000. 190p.

REVISTA NOVA ESCOLA. São Paulo: Editora Abril, v.16, v.17, 2001-2002.

RIO, V.Del; OLIVEIRA, L. Percepção ambiental: a experiência brasileira. São Paulo: Studio Nobel, 1999. 265p.

ROUSSEAU, J-J. Emílio ou da educação. Rio de Janeiro: Bertrand Brasil, 1995. 592p.

SACHS, I. Ecodesenvolvimento : crescer sem destruir. São Paulo: Vértice, 1986. $208 p$. 
SACHS, I. Estratégias de transição para o século XXI. São Paulo: Nobel, 1993. 104p.

SANTOS, B.S Pela mão de Alice - o social e o político na pós modernidade. São Paulo: Cortez, 2000. 350p.

SANTOS, B.S A crítica da razão indolente - contra o desperdício da experiência. São Paulo: Editora Cortez., 2001. 415p.

SANTOS, B.S. Um discurso sobre as ciências. 13.ed. Porto: Edições Afrontamento, 2002. 59p.

SATO, M. Debatendo os desafios da educação ambiental.(2001). http://www.sf.dfis.furg.br/mea/remea/congress/artigos/mesa04.pdf (14 jan. 2004).

SAWAIA, B. B. Participação social e subjetividade. In: SORRENTINO, M. (org.) Ambientalismo e participação na contemporaneidade. São Paulo: Ed. EDUC, 2001, p.115-134.

SCIADINI, P. San Juan de la Cruz: o poeta de Deus. São Paulo: Palas Atenía, 1989.p.152

SCHAMA, S. Paisagem e memória. São Paulo: Companhia das letras, 1996. 645p.

SCHUMACHER, E.F. O negócio é ser pequeno. Rio de Janeiro : Zahar Editores, 1983. $261 p$.

SERRES, M. O contrato natural. Lisboa: Instituto Piaget, 1994. 196p.

SORRENTINO, M. Educação Ambiental e Universidade: um estudo de caso. São Paulo, 1995. 272p. Tese (Doutorado) - Faculdade de Educação, Universidade de São Paulo. 
SORRENTINO, M. Educação ambiental e sociedade: um estudo de caso. In: PADUA, S.M.; TABANEZ, M.F. (org.) Educação ambiental: caminhos trilhados no Brasil. Brasília: Ed.Pax, 1997a. p. 43-54.

SORRENTINO, M. Vinte anos de Tblisi, cinco da RIO 92: A Educação Ambiental no Brasil. Debates Socio Ambientais - CEDEC. v.2, n.7, 1997b.

SORRENTINO, M. Avaliação de processos participativos. Ambientalismo e participação na contemporaneidade. São Paulo: Ed.EDUC, 2001. p.215-223.

TAMAIO. I. O professor na construção do conceito de natureza: uma experiência de educação ambiental. São Paulo: Annablumme: WWF, 2002. 157p.

TASSARA, E.T.O. Utopia e Anti-Utopia: o Ressuscitar da História. In: SOUZA, L.; FREITAS, M.F.D.; RODRIGUES, M.M.P.(org.). Psicologia: reflexões (im) pertinentes. São Paulo, 1998, v.1, p 13-24.

THIOLLENT, M. Metodologia da pesquisa-ação. São Paulo: Cortez Editora, 1985. $108 p$.

THOMAS, K. O homem e o mundo natural. São Paulo: Companhia das letras.1988. $456 p$.

TUAN, Y. Topofilia. São Paulo: Difel, 1980. 288p.

TUAN, Y. Espaço e lugar. São Paulo: Difel, 1983. 250p.

UNGER, N. M. Da foz à nascente o recado do rio. Campinas, SP: Editora da UNICAMP, 2001. 202p.

VIEIRA,S.L. A democratização da universidade e a socialização do conhecimento. A universidade em questão. São Paulo: Ed. Cortez, 1989.102p. 
WEIL, S. O enraizamento. Bauru; SP: Edusc, 2001. 274p.

YIN, R.K. Case study research:design and methods trad. de Pinto, http://www.eac.fea.usp.br/metodologia/estudo_caso.asp (04 jun. 2003).

ZAGO, J.A. Drogadição: um jeito triste de viver. http://www.adroga.casadia.org/tratamento/DROGADICAO_UM_JEITO_TRISTE_DE_VIVER .htm (10 maio 2004). 
APÊNDICES 
APÊNDICE1

\title{
FORMAÇÃO DE EDUCADORES AMBIENTAIS PARA SOCIEDADES SUSTENTÁVEIS
}

\author{
PLANO DO CURSO PILOTO
}

Organização e Coordenação

Laboratório de Educação e Política Ambiental - LEPA

Promoção

Instituto de Pesquisa e Estudos Florestais - IPEF

\begin{abstract}
Realização
Departamento de Ciências Florestais

ESALQ/USP

Apoio

Prefeitura da Cidade de Piracicaba

Diretoria Regional de Ensino de Piracicaba

Centro Educacional e Tecnológico Paula Souza - CEETPS
\end{abstract}

Maio/2000 


\section{INTRODUÇÃO e JUSTIFICATIVA}

A formação de recursos humanos na área ambiental tem-se constituído um desafio na atualidade para as diversas instituições educacionais. Muitos cursos têm sido criados com o objetivo de qualificar profissionais que atendam as especificidades dessa área. Entretanto, a demanda desses profissionais com uma qualificação mínima para contemplar as especificidades emergentes, em especial quando se trata de intervenção nos espaços sócio-ambientais, está muito aquém das necessidades geradas.

Essa qualificação parece estar fundamentalmente comprometida pelos processos pedagógicos dominantes nas práticas educacionais encontradas nos vários níveis de ensino. Práticas essas que, segundo inúmeros estudos realizados sobre as mais diferentes áreas e níveis do conhecimento das últimas décadas, se apresentam respaldadas numa concepção de construção de conhecimento que se caracteriza por ser asséptica, distanciada da experiência, dos interesses e das capacidades dos alunos desenvolvidas nas e das suas relações sociais.

No que se refere a temática ambiental, esta tem se construído da participação efetiva de profissionais, especialistas e pesquisadores dos mais variados campos do conhecimento evidenciando, portanto, sua natureza multi e interdisciplinar.

O envolvimento desses profissionais com a área ambiental tem proporcionado reflexões importantes que revelam a sua complexidade intrínseca e suas repercussões nos mais variados campos de atuação que envolvem a vida moderna.

A situação sócio-ambiental brasileira atual é resultado da história da degradação ambiental. Ao "comemorarmos" 500 anos de descoberta do país, devemos na verdade refletir sobre o significado desse período, que numa análise mais minuciosa revela muito mais a dominação e a exploração da nossa cultura, do nosso povo e de nossa natureza "natural", do que o encontro do velho mundo com o novo mundo. O que temos é um país jovem com todos os vícios e defeitos do velho mundo, com o agravante de que grande parte de nossa população não usufrui dos avanços sociais conquistados, nesse período, por grande parte da população dos países do primeiro mundo.

Desse modo, a Educação Ambiental tem sido considerada como um espaço ou uma área que, ao levar em conta essas críticas aos modos de utilização do conhecimento, em especial o científico, para exploração do ambiente e das sociedades e as suas conseqüências sobre a vida humana de um modo em geral, deve ser reconhecida como um dos instrumentos importantes para promover mudanças nos modos dominantes do pensamento moderno. Nesse sentido, deve incorporar as críticas dirigidas ao pensamento científico moderno, tais como: a) postular a posse de um conhecimento verdadeiro, real e objetivo com validade universal; b) postular uma concepção mecanicista, formalista e analítica da natureza; c) postular a especialização, a fragmentação do conhecimento para sua transmissão pelo ensino; d) postular a supremacia da razão e do intelecto sobre todos os demais aspectos da experiência e das capacidades humanas; e e) postular a hegemonia do método experimental e dedutivo(Japiassú, 1975).

O posicionamento crítico frente a essas características do pensamento da modernidade, tem-se constituído num dos fundamentos adotados para a Educação Ambiental. 
A Educação Ambiental, através de sua especificidade, ou seja, de sua preocupação com a situação geral (mundial) e particular (regional, local), atende e retoma as finalidades amplas da educação. Devemos relembrar que integram essa especificidade o atendimento de fatores que interferem nos problemas ambientais, sob aspectos econômicos, sociais, políticos e ecológicos; a aquisição de conhecimento, de valores, de atitude, de compromisso e de habilidade necessários para a proteção e melhoria do meio ambiente; a criação de novos padrões de conduta orientados para a conservação, recuperação e melhoria da qualidade do meio ambiente e da qualidade da vida. (Castro e Spazziani, 1998,p.195/6)

Essa concepção de Educação Ambiental é resultado da consciência ecológica que foi se construindo a partir da multiplicidade de fontes de informações, vivências e reflexões que constitui a modernidade, A consciência ecológica se impõe tanto mais quando há a participação ativa da população na resolução dos problemas locais. O movimento intitulado "ambientalismo" estrutura-se, nas décadas de 60 e 70, através da conscientização de certos grupos da sociedade sobre a degradação dos ambientes naturais e da utilização predatória dos recursos ainda existentes. Vários grupos organizam-se no sentido de promoverem a divulgação dos abusos que se vem praticando ao meio natural e conseqüentemente à vida do planeta em todas as suas manifestações, afetando especialmente as condições da vida humana (Sorrentino, 1995).

Esse movimento dos tempos modernos, da industrialização, da economia globalizada, da tecnologia de comunicação, ao fazer uso dos avanços científicos e tecnológicos tem favorecido a degradação dos ambientes naturais e humanos ao mesmo tempo que promove conhecimentos que resultam em possibilidades culturais até então não vivenciados.

As novas tecnologias de comunicação são produzidas na e pela modernidade, como nos lembra Pierre Lèvy (1995), fazem parte do cotidiano da contemporaneidade e das representações e do imaginário do indivíduo moderno e pretendem, assim como as formas pioneiras de comunicação (a imprensa escrita e a falada), ser uma das principais ferramentas de difundir informações e educação para a população.

Naquilo que se refere a formação de profissionais para atuarem na área ambiental, o acesso a essas novas tecnologias de comunicação permite apostar em outras formas de conhecimento e formação.

A educação à distância tem sido uma modalidade de ensino que tem atuado de forma suplementar na formação ou aperfeiçoamento de pessoas em algumas áreas, em especial em cursos técnico-profissionalizantes. No entanto, nas duas últimas décadas, com o avanço dos computadores o uso das tecnologias de comunicação para a educação tem sido evidenciada. O surgimento de novos serviços educativos variados e inovadores se combina com os serviços já existentes promovendo verdadeira revolução nas formas de educação à distância.

"A instrução via meios de comunicação está se tornando menos um enteada dos sistemas educacionais e cada vez mais sua vitrina. A televisão da Universidade aberta Britânica, tratada com ceticismo quando Ihe foi dado o Alvará Real em 1969, agora envolve, anualmente, uma média de 60mil estudantes e concedeu quase 100 mil títulos universitários"(White e Thomas, 1995, p.47). 
No Brasil essa revolução dos meios de comunicação, via informática, também já atingiu o cotidiano das pessoas. O uso de cartões eletrônicos no sistema bancário, os computadores domésticos têm crescido em nosso país a uma velocidade estonteante, a comunicação via correio eletrônico se configura nos programas de tv com uma participação significativa, a internet faz parte do dia a dia de centenas de milhares de jovens. Sem contar que os jovens de hoje foram formados tendo a televisão como um dos principais veículos de entretenimento e informação e são os maiores consumidores de fitas de vídeo e videogames.

Paralelamente tem havido uma larga discussão sobre o papel da escola enquanto formadora de cidadãos e recursos humanos para o mercado de trabalho. Essa discussão apontada em inúmeros estudos e teses indica que as formas de atuação ou a pedagogia dominante nos modos de ensinar tem sido uma das grandes responsáveis pela evasão escolar em todos os níveis do ensino formal. A forma tradicional das aulas pressupõe o professor como o centro do sistema, que ao formular seu ensino prioriza no programa curricular um saber instituído em detrimento do estudante com suas vivências e experiências.

Essas críticas direcionadas ao ensino formal, bem como aquelas que denunciam as formas de utilização dos recursos ambientais e humanos exigem uma perspectiva diferenciada de formação de recursos humanos para a área da Educação Ambiental.

Nesse sentido, o Laboratório de Educação e Política Ambiental (LEPA) do Departamento de Ciências Florestais/ESALQ/USP, pretende desenvolver um programa de formação de especialistas comprometido com a construção de uma "práxis" de Educação Ambiental dentro da realidade brasileira, desenvolvendo, no plano do curso, outras possibilidades pedagógicas, tais como: priorizar o projeto de intervenção educacional do aluno (eixo transversal do curso); disponibilizar tecnologias de comunicação de formas variadas; promover um cardápio de disciplinas ou módulos que atendam a heterogeneidade de problemáticas da demanda e que esteja de acordo com as necessidades coletivas.

Fundamentado na perspectiva do "Tratado de Educação Ambiental para Sociedades Sustentáveis e Responsabilidade Global" (1992) e nos documentos internacionais que delineiam as grandes orientações para a Educação Ambiental (Estocolmo, 1972; Tbilisi, 1977; Rio, 1992; Guadalajara, 1993), e tendo como pano de fundo uma análise crítica sobre a crise sócio-ambiental atual e as diversas respostas que vêm sendo dadas na contemporaneidade pelas ciências, pela política, pelas instituições educacionais, pelos movimentos sociais e religiosos, entre outros se propõe a organizar e desenvolver esse programa de formação de educadores ambientais.

\section{ORGANIZACẼO DO CURSO}

PÚBLICO ALVO: Professores e outros profissionais da educação e/ou meio ambiente interessados em se qualificar para a realização de projetos de Educação Ambiental voltados para a transformação sustentável da sociedade.

OBJETIVOS: 1. Contribuir para a formação de especialistas, capacitando-os para atuarem como educadores ambientais; 
2. Propiciar aos participantes um aprofundamento teórico-prático em questões pertinentes ao exercício das atividades de educadores ambientais;

3. Propiciar uma formação comprometida com a transformação e o desenvolvimento profissional dos sujeitos participantes com reflexo na sua prática social;

4. Estimular e apoiar o planejamento, a realização e a avaliação de projetos de intervenção educacional perspassado pela perspectiva de sustentabilidade em suas diversas dimensões;

5. Possibilitar aos participantes a aquisição de repertórios que lhes propiciem atuar na formação de educadores ambientais.

O PROGRAMA: Consta de um conjunto de disciplinas e atividades, organizadas em módulos, que serão trabalhadas de forma presencial e a distância consubstanciadas em práticas pedagógicas que pressupõem o aprender fazendo, o princípio da criticidade e da historicidade, assim como, a valorização do trabalho coletivo que requer um ambiente e uma organização do espaço e dos instrumentos diferente da que se tem conhecimento nas formas tradicionais de ensino. O ambiente escolar deve propiciar a colaboração, que pressupõe a realização de tarefas em que os sujeitos/alunos são instigados a trabalhar em conjunto para produzir algo que não conseguiriam individualmente.

Nesse sentido, o desenvolvimento intelectual dos alunos é concebido como resultado de atividades culturalmente organizadas, enfatizando-se a natureza interativa das relações sociais, que promovem mudanças comportamentais tanto em termos de transferência de responsabilidade como de controle; os participantes mais experientes (professores, tutores, alunos) podem estruturar interações onde os menos experientes participam de atividades em que não eram capazes se deixados sozinhos (sem orientação).

\section{MÓDULOS DO CURSO: DISCIPLINASIATIVIDADES} intervenção:

O curso está organizado em três módulos: estruturante, informativo e de

- módulo estruturante consta de um conjunto de atividades que têm por objetivo estruturar o grupo enquanto uma comunidade de aprendizagem o projeto de intervenção nas suas várias etapas: concepção, elaboração, fundamentação teórica e metodológica, formatação, apresentação e avaliação.

- módulo informativo consta de um conjunto de disciplinas que serão desenvolvidas para fundamentar teórica e metodologicamente os projetos de intervenção educacional. São elas:

. Metodologia da pesquisa e da intervenção educacional;

- Técnicas de Elaboração de Projetos;

. Desenvolvimento humano e processos de conhecimento e de aprendizado;

. A formação do educador-pesquisador;

. Práticas pedagógicas participativas de ensino;

. Pressupostos da Educação Ambiental: interdisciplinaridade, partici-

pação, conscientização, dialogicidade, dentre outros.

. Estudo do meio reconhecendo o próprio meio; 
. Educação comunitária e geração de trabalho e renda c/ sustentabilidade;

. Contemporaneidade e Educação Ambiental;

. Ambientalismo e Sustentabilidade;

- módulo de intervenção está organizado de modo a propiciar ao aluno a realização/execução do projeto nas suas diferentes etapas (diagnóstico, pesquisa de campo, intervenção propriamente dita e avaliação).

\section{O PROJETO DE INTERVENÇÃO EDUCACIONAL}

Deverá ser um ponto de convergência de todo o processo pedagógico desenvolvido no curso, para tanto, espera-se como resultado, ao final do curso, um projeto de caráter prático, útil para a comunidade na qual está inserido o profissional/aluno e que possa ser incorporado a curto ou médio prazo pela instituição:

a) Será utilizado para avaliação do aluno, enquanto produto (final) do curso, e, ainda, deverá ser avaliado como processo de desenvolvimento/crescimento do profissional/estudante durante o curso e enquanto educador ambiental, preocupado e consciente da sua importância enquanto formador/multiplicador;

b) Deve ter uma abordagem que considere os aspectos técnicos/políticos/culturais da questão estudada. É um espaço de geração de idéias, criação, aproximação do estudante com o meio, com o curso, com os profissionais envolvidos (tutores, colegas etc), proporcionando o envolvimento e a participação entre os diferentes setores acadêmicos e sociais;

c) O Projeto de Intervenção Educacional faz parte da exigência do Curso para a obtenção do certificado;

O aluno, através de seu Orientador, deverá remeter a Equipe Coordenadora, o texto final do Projeto para a aprovação dentro dos prazos estabelecidos

\section{A METODOLOGIA DO CURSO}

No decorrer das atividades e disciplinas desenvolvidas durante o curso, alguns pressupostos metodológicos deverão estar presentes nas práticas pedagógicas dos diferentes professores e profissionais que atuam nesse programa, entre os quais destaca-se:

a) partir da prática dos profissionais/alunos para inserir as teorias que cercam as áreas estudadas, ou seja a teoria fazer ponte com a prática: a práxis;

b) priorizar o trabalho coletivo do grupo de alunos entre si, com os docentes e com a coordenação do curso para que aprendizagem se realize num ambiente de construção coletiva do conhecimento, através: do diálogo constante sobre as prática exercidas e as idéias que se tem sobre as mesmas; do ambiente de confiança e respeito entre o grupo para que as idéias e os conflitos manifestemse de forma construtiva e se possa avançar no conhecimento; da promoção da autonomia dos profissionais e da capacidade de análise crítica; da valorização de sua inserção profissional como sujeito competente e transformador; da compreensão dos conteúdos, métodos e técnicas que o instrumentalize para a intervenção educacional nos espaços de atuação.

c) tratar o tema meio-ambiente no marco amplo da educação, da realidade local e da sociedade mais geral; 
d) consubstanciar a prática pedagógica do curso comprometida com a transformação da prática do profissional-aluno e da sociedade;

e) conceber o sujeito em formação como portador de um saber que quer aprofundar, a partir de sua inserção profissional e de sua realidade institucional/local;

f) utilizar nos cursos estratégias participativas, "dialogizantes" onde o trabalho coletivo, nas aulas e nos projetos de intervenção, seja a principal fonte de construção do conhecimento;

g) desenvolver princípios de autonomia, criatividade e solidariedade;

h) utilizar diferentes linguagens de comunicação (oral, escrita, música, dramatização, simulação, histórias) e de tecnologias de comunicação (vídeo, tv, internet).

A incorporação dos meios de comunicação no curso deve estar ancorada em critérios e estratégias de ensino que garantam a qualidade do processo educativo e a relevância pessoal e social dos resultados. Em acordo com os pressupostos estabelecidos para o curso como um todo, cada módulo ou disciplina estará sendo adequado pelo professor em constante diálogo com os alunos sobre os modos de condução dos métodos e dos ambientes interativos necessários no decorrer das aulas.

\section{O CORPO DOCENTE}

Será constituído por professores portadores de títulos de Mestre e/ou Doutor, devidamente autorizados pela Coordenação do curso, podendo ser docente da USP, de outras instituições universitárias do País ou do Exterior, bem como por técnicos ou professores autônomos com relevante atuação na área.

a) O professor do curso estará presente durante todo o processo de concepção do programa, no planejamento das aulas, materiais e recursos didáticos, que deverão estar em coerência com o desenho do curso como um todo, assim como, deverá promover a articulação do programa de sua disciplina com o projeto de intervenção do aluno;

b) $\mathrm{Na}$ parte do curso que for designada para ser realizada sob a mediação de recursos didáticos (textos, vídeos, pesquisas, intervenções, entre outras) caberá ao professor e à coordenação do curso estabelecer ações tutoriais através dos meios de comunicação (correio, telefone, E.mail, ou outra);

c) São atribuições dos membros do corpo docente:

c.1. ministrar aulas teóricas e práticas de acordo com as orientações estabelecidas nesse plano do curso, supervisionar outras atividades programadas, complementares às aulas, assim como avaliar e atribuir o nível de aproveitamento dos alunos;

c.2. acompanhar os trabalhos dos alunos realizados presencialmente e à distância;

c.3. orientar os trabalhos de monografias quando escolhido para essa finalidade;

c.4. acompanhar o projeto de intervenção do aluno do qual foi orientador;

c.5. participar de comissões julgadoras;

c.6. propor a criação e a extinção de disciplinas/módulos, mediante a aprovação da coordenação do curso.

d) São atribuições do professor-orientador:

d.1. orientar o aluno em todas as questões referentes ao trabalho monográfico de intervenção educacional; 
d.2. acompanhar o trabalho de intervenção educacional, devendo rever e aprovar a redação final do texto monográfico, assim como participar do Exame da Monografia dos seus orientados.

\section{Membros do corpo docente}

. Prof. Dr. Marcos Sorrentino (Coordenador) - Esalq/USP

. Prof. Dr. Moacir Gadotti - PUC/SP

. Profa. Dra. Eda T. O .Tassara - Psicologia Social/USP

. Profa. Dra. Lúcia da Costa Ferreira - Nepam/UNICAMP

. Profa. Dra. Maria de Lourdes Spazziani - Esalq/USP

. Profa. Especialista Sandra Lestinge - Esalq/USP

. Profa. Dra. Margareth Brandini Park - Unifran

. Prof. Dr. Ronaldo de Souza Castro - FE/UFRJ

E outros profissionais de reconhecida atuação na área.

\section{O CORPO DISCENTE}

Deverá ser constituído por alunos, cujas perspectivas profissionais estejam relacionadas com o desenho do curso e, como exigência individual dos alunos, solicitase: dedicação, capacidade de controlar o tempo, gosto pela pesquisa, motivação profissional, seriedade, compromisso, disciplina e busca de autonomia:

a) O estudante deverá ter no decorrer do curso, uma boa disciplina e estímulo para que o seu momento de estudo individual seja produtivo, daí a importância de que seja autônomo e esteja motivado;

b) O horário livre para o estudo dará mais flexibilidade para o estudante, que poderá utilizá-lo em pesquisa virtual (via Internet) ou presencial, na biblioteca; leitura do material didático disponibilizado pelo curso; realização de atividades propostas; trabalhos em grupo (desenvolvidos também de forma presencial ou virtual) ; ou outro recurso de que disponha;

c) O aluno deverá sempre ser estimulado a buscar suas próprias fontes de informação, conforme o que tiver a disposição no local;

d) A inscrição no curso será feita através de requerimento, em formulário próprio, fornecido pela Coordenação do Curso, juntamente com o comprovante de conclusão do curso superior e outros documentos necessários;

e) Após o exame da documentação, a Coordenação do Curso, selecionará os alunos que deverão requerer sua matrícula, apresentando os documentos necessários.

\section{CARGA HORÁRIA E DURAÇÃO DO CURSO}

A totalização dos estudos necessários à formação dos profissionais em nível de especialização, será expressa em uma carga horária de 720 horas, integralizadas da seguinte maneira: 360 horas/aula em aulas e atividades presenciais e 360 horas/aula em aulas e atividades realizadas à distância, incluindo as 185 horas/aula para a realização do projeto de intervenção. 
a) A duração do curso está previsto para um ano de integralização das horas de aulas presenciais, a distância e a realização do projeto de intervenção;

b) É necessário a freqüência às aulas, não podendo o aluno faltar mais do que $15 \%$ da carga horária (presencial) de cada disciplina ou atividade;

c) No período letivo, o aluno terá avaliações no decorrer das disciplinas/atividades dos módulos;

d) O aluno deverá ter aproveitamento em todas as disciplinas/atividades, relacionando constantemente ao seu projeto de intervenção;

e) O aluno que não obtiver a freqüência mínima às aulas e/ou não cumprir as atividades necessárias para o desenvolvimento do seu projeto de intervenção dentro dos prazos estabelecidos será desligado do Curso.

\section{BIBLIOGRAFIA}

BRASIL. Secretaria de Educação Fundamental. Parâmetros curriculares nacionais: Introdução. Brasília:MEC/SEF, 1997a.

- Parâmetros Curriculares nacionais: apresentação dos temas transversais, ética. Brasília: MEC/SEF, 1997b.

. Parâmetros curriculares nacionais: meio ambiente e saúde. Brasília: MEC/SEF,1997c.

BRASIL. Imprensa Nacional. Lei no. 9795 de 27/4/1999. Diário Oficial, 28/04/1999b.

. Programa Nacional de Educação Ambiental - PRONEA. Diário Oficial, 22/14/1994.

BRASIL. MEC/Secretaria de Ensino Fundamental. Referenciais para a formação de professores. Brasília.: SEF, 1999a.

LÉVY, P. As tecnologias da inteligência. São Paulo: Editora 34, 1995a.

NÓVOA, A.(coord.) . Os professores e a sua formação. Lisboa: Dom Quixote, 1992.

PRETTO, N. L. Uma escola sem/com futuro - educação e multimídia. São Paulo: Papirus, 1996.

SACHS,I. Espaços, tempos e estratégias do desenvolvimento. São Paulo: Vértice, 1986.

SCHÖN, D.A La formación de profesionales reflexivos: hacia un nuevo diseño de la enseñanza y el aprendizaje en las profesiones. Barcelona: Paidós, 1992.

SFEZ, L. Crítica da comunicação. São Paulo: Loyola, 1994.

STENHOUSE, L. La investigación como base de la enseñanza. Seleção de textos de J. Rudduck e D. Hopkins. Madrid: Morata, 1993.

SORRENTINO, M. Educação Ambiental e Universidade: um estudo de caso. São Paulo: USP, 1995 (Tese de doutoramento).

SPAZZIANI,M.L., CASTRO,R.S., SANTOS,E.P. Universidade, educação ambiental e parâmetros curriculares nacionais. IN: Loureiro,C.F.B.,Layrargues, Castro,R.S. Sociedade e meio ambiente: a educação ambiental em debate (no prelo).

UNESCO. Educação Ambiental: as grandes orientações da Conferência de Tbilisi, 1997.

UNIVERSIDAD DE GUADALAJARA. Congresso Iberoamericano de educación ambiental. Guadalajara, Colecion: Sociedade y ambiente, 1993. 
WHITE,R.A e THOMAS,P. Ensino a distância: experiência e inovações. In: Comunicação e Educação, 3. São Paulo, 1995, p.47-56. 


\section{APÊNDICE 2}

Foram 22 avaliações respondidas, no último dia e período em Itatinga.

Com relação a preparação para a disciplina (etapa anterior à viagem), 18 alunos consideraram que foi boa, sendo os motivos apontados:

- Bom desempenho dos coordenadores

- Bom planejamento

- Folheto com itens básicos ajudou

- Orientação sobre o que iria acontecer, trouxe segurança

- Explicação detalhada

- Experiência em lidar com pessoas "bem urbanas"

- $\quad$ Saiu como planejado

- Comunicação pelo RITS foi suficiente

- Acalmou o grupo, fazendo-o parar para pensar o pq de estar ali

As contribuições deles para melhoria deste item:

- Entregar o histórico do horto para ser lido antes

- Mostrar fotos do local

- Antes de iniciar um trabalho, apontar qual a expectativa ao final dele

Nenhum achou ruim, e os que consideram razoável (3 alunos) foi pelos motivos:

- $\quad$ problemas com as datas - calendário

- $\quad$ solução parcial para os acompanhantes

e as contribuições deles para melhoria deste item:

- $\quad$ viagem na época de planejamento escolar

- $\quad$ não permitir muitas discussões sobre as datas

- $\quad$ ser mais claro sobre os acompanhantes

Com relação a viagem, de uma forma geral, 17 alunos consideraram boa, sendo os principais motivos:

- Reencontro com a turma

- Entrosamento com as pessoas q tinha pouco contato,

- Socialização das expectativas

- Boa organização

- Ônibus em bom estado, motorista responsável, agradável

- Momento "livre", de "recreio" que precisávamos

- $\quad$ pessoal com espírito aberto

- Foi rápida, no horário combinado

- Pessoal cooperativo

- Tranqüilidade

As contribuição para este momento:

- Ter combinado a saída mais cedo 
- Ter um momento dirigido p/ ampliar conhecimentos, aproveitando-se o trajeto do ônibus

- $\quad$ Fazer dinâmicas (piadas ou karaokê) durante a viagem

Apenas dois alunos a consideram razoável por passarem mal em viagem de ônibus.

Quanto ao local escolhido(Estação Experimental de Itatinga)

17 alunos consideraram bom, e os motivos:

- gostaram do local

- proximidade (em relação a Piracicaba) e com estrutura para realizar as atividades

- $\quad$ perfeito para realizar os estudos do meio

- não conheço outro que fosse melhor

- bonito, tranqüilo e acolhedor

- conhecimento da importância da área p/ Educação

- $\quad$ surpresas, sons que acalmam, isolamento

- lugar rico de informações e estímulos para vivência

- $\quad$ pessoal do horto receptivo

- $\quad$ de fácil acesso mas difícil dispersão da atenção (?)

- $\quad$ muitos espaços para serem observados, analisados, sentidos

- $\quad$ atendeu as expectativas, diversidade

- natureza com conforto de casa, todo o grupo se sentiu bem

- os elementos naturais e antrópicos contemplaram as expectativas

- $\quad$ conheci um lugar para trabalhar com o público-alvo

- despertou interesse para vir aqui realizar algum estudo

As contribuições dos alunos no que se refere ao local:

- fazer patrimônio em Brotas

- um dia a mais para evitar correria

- $\quad$ procurar locais onde todas as pessoas se sintam bem p/ a boa realização da proposta

- $\quad$ melhorar alojamento IV

Um aluno considerou ruim por estar muito antropizado, sem privacidade (para o grupo) e como sugestão deixou a idéia de ir para um Parque Estadual, mesmo que se pagasse diárias para garantir maior concentração para os trabalhos.

Quatro alunos consideram razoável pelos seguintes motivos:

- $\quad$ tipo de ambiente (estação experimental)

- mata de eucaliptos

- muito lindo mas falta mata nativa e passarinho

- esperava um local menos antrópico, mesmo assim vocês conseguiram tranformá-lo num "paraíso".

As contribuições advindas desses alunos foram de:

- fazer a disciplina em Unidade de Conservação, com vegetação nativa, seria melhor $\mathrm{p} /$ discutir aspectos da EA

- (a estação) é ótima também, sabendo aceitar o local 
Dezoito alunos consideraram o banho de Cachoeira bom, sendo os motivos:

- $\quad$ só fui no segundo dia, estava ansiosa, adoro água

- descarrego!

- Deu uma energizada, tirou o "pó da garganta", animando para seguir a trilha

- O significado do banho de cachoeira

- acalmou as expectativas de laser q poderiam desconcentrar o grupo

- quebrar o gelo sobre o lugar desconhecido

- $\quad$ estava precisando descarregar e só percebi chegando lá

- $\quad$ ela é forte como um transe

- melhor lugar do mundo

- fundamental como "chegada" para relaxar a galera

- relaxamento, descontração

- gelada, gostosa, ótima localização

- nos faz crianças

- massagem natural

- deliciosa

Sua contribuição:

- todo dia ter um tempinho prá curtir este lugar

- $\quad$ sempre deve haver lazer

- $\quad$ poderia ter sido na hora mais quente do dia

- $\quad$ antes do almoço, o calor estimula

quatro alunos consideraram a atividade razoável pelo seguintes motivos:

- imaginava que a queda d'água fosse maior

- horário

- $\quad$ equena, tinha expectativa que tivesse espaço $\mathrm{p} /$ nadar. O entusiasmo do grupo e é sempre maravilhoso poder tomar banho de cachoeira, compensou...

Sua contribuição:

- $\quad$ ir mais cedo para aproveitar mais

Roda na fogueira

Dezesseis alunos consideraram a atividade boa, pelos seguintes motivos:

- lado místico, harmonioso

- o ritmo contagiou a moçada, nos sentimos mais primitivos e esquecemos um pouco nossas complexidades

- momento de recepção acolhedora

- $\quad$ novidade para mim

- $\quad$ percebi como as pessoas se harmonizam

- descontração

- reflexão

- $\quad$ entre as árvores, paz e tranqüilidade

- $\quad$ interação, expectativa e vivência nova com os diversos instrumentos 
- quebrar o gelo entre a galera, me ajudou a relaxar, sem me preocupar se estava pagando "mico"

- $\quad$ significado do fogo

- $\quad$ surpreendente tempo de compartilhar

- foi um belo exemplo de necessidade de harmonia num grupo

- $\quad$ experiência com instrumentos q não conhecia e que a Sandra me ensinou a compartilhar

As contribuição dos alunos advindas dessa atividade são as seguintes:

- $\quad$ poderia explorar mais e compartilhar aspectos culturais

- convidar quem sabe tocar p/ puxar o som

- ter um tempo maior para ela

- é bom quando alguém toma a iniciativa de conduzir o grupo para harmonização (Noeli)

Um aluno considerou ruim pois achou a atividade sem sentido.

Três alunos consideraram razoável pelos seguintes motivos:

- poderia ser a noite

- faltou algo

- gerou ansiedade e um certo constrangimento, foi como enfrentar um pequeno desafio

ótimo 1

motivo

- $\quad$ antes de chegar pensei em como seria propício, e depois a encontrei (fogueira) contribuição:

- $\quad$ poderia ser melhor explorada com dinâmica de integração

Atividades do dia 26:

$\mathrm{Na}$ atividade de "Aprendizado com a natureza" 20 alunos a consideraram boa, pelos motivos:

- $\quad$ consegui achar todos os objetos da trilha, foi um desafio, me deixou muito feliz

- $\quad$ poderei usar as técnicas com as minhas turmas

- os jogos contribuíram para união, quebrar o gelo, aperfeiçoar a observação

- todas as atividades foram deliciosas, aguçaram o olhar, a audição e a própria expressão

- criativo, envolvente, bem elaborado

- $\quad$ percebi o quanto preciso conhecer e sentir

- treinar os olhos para enxergar a natureza de diferentes formas e melhor entendê-la

- eu já amo o Cornell, experienciar "na pele" foi muito legal, apuramos nossa percepção

- $\quad$ novas sensações, percepções, descobertas exteriores e interiores

- $\quad$ aprendizado com os sentidos 
- $\quad$ cheiro de mato, ar puro, silêncio

Contribuições:

- cuidado com as frases em corujas e corvos

- $\quad$ sortear duplas aleatórias

um aluno considerou excelente pelo motivo de que foi um excelente exercício

Na atividade de "Estudo do meio" treze alunos a consideraram boa, pois:

- $\quad$ era o que estava esperando

- $\quad$ onde tivemos momentos de campo-roça prático

- mais informações sobre as atividades do horto

- metodologia, estruturação, vivência prática

- trabalhamos em grupo, montamos uma apresentação

- $\quad$ para conhecermos por nós mesmos o local onde estamos

- ampliou meus conhecimentos e percepção

- enriquecedor, significativo, interessante

- descobri o que é um estudo do meio, a Sandra soube orientar na apresentação

- colocar na prática o que foi trabalhado na manhã

- $\quad$ pude aprender mais sobre horta, irei utilizar no meu trabalho

- $\quad$ as dicas no dia seguinte supriram minhas necessidades

As contribuições foram:

- $\quad$ apresentação no local de estudo

oito alunos consideraram razoável pelos seguintes motivos:

- a apresentação poderia ter sido feita "in loco"

- $\quad$ não entendi direito o q foi pedido

- $\quad$ falta de clareza na apresentação da proposta e falta de apoio do grupo

- faltou tempo, houve muita ansiedade

- coordenação me pareceu ausente e insegura

As contribuições que fizeram são as seguintes:

- $\quad$ perguntar, não sair com dúvidas

- maior esclarecimento do tema

- ouvir alguns elementos dos grupos para ver se entenderam o objetivo da proposta

- amarrar conceitos importantes ao final das etapas

- maior discussão antecedente, disponibilizar os guias e as experiências relatadas

- $\quad$ mais tempo

Rildo/palestra

Apenas 9 alunos a consideraram boa, pelos seguintes motivos:

- $\quad$ a contextualização do horto no aspecto histórico, social e acadêmico

- conhecimento geral do local, foi um complemento 
- $\quad$ importante conhecer a história, as facilidade e dificuldades vividas num espaço que parece tão harmônico

- o momento poderia ter sido repensado em virtude dos conflitos do grupo

- $\quad$ conhecer melhor os potenciais e os problemas do horto

Um aluno achou ruim 1, pela inibição do palestrante e doze alunos, razoável, pelos motivos:

- $\quad$ pelo tempo que ele tem no parque poderia ter mais atividades e novas propostas

- $\quad$ tímido e falava um pouco confuso, dificuldade de expressão

- a turma estava cansada

- $\quad$ está meio fora do que nós sonhamos

- clima tenso

- $\quad$ informações que eles precisam resolver (isso 14.000)

- devia ter uma paradinha $\mathrm{p} /$ repor energias

- desgaste pessoal

contribuição:

- controlar melhor o tempo, inserir intervalo, intervir na discussão p/ esclarecer quando necessário

- maior trabalho de marketing do horto

- $\quad$ realizar (palestra) após atividade agitada fisicamente

a noite fizemos avaliação do dia e treze alunos consideraram que foi boa, pelos seguintes motivos:

- $\quad$ processo participativo

- $\quad$ o pessoal coloca para fora angústias e expectativas em relação ao curso, isso é bom

- $\quad$ entendi vários pontos sobre o dia todo

- $\quad$ agradável com o grupo

- dentro do esperado

- o "quebra-pau" foi fundamental p/ colocar as idéias no lugar

- $\quad$ aprendemos a ouvir e dar importância à opinião dos outros, respeitar limites

- para colocar nossas ansiedades sobre o estudo do meio e do curso como um todo

- $\quad$ o grupo mostrou insatisfação e a coordenação correspondeu e satisfez a nossa necessidade

as contribuições:

- $\quad$ poderia ser alternada entre discussões em grupos e porta-voz, para q todos contribuam, evitando ouvir sempre os mesmos colegas dominantes

- adotar regras de respeito a opinião alheia

- combinar um horário mais cedo

4 alunos consideraram razoável, pelos seguintes motivos:

- já estavam cansados, o rendimento caiu

- houve dispersão do grupo

- $\quad$ Faltou energia elétrica o que motivou atrasos e stress 
contribuições:

- programar atividades relaxantes

mais ou menos 1

motivo:

- $\quad$ poderia ter sido melhor se não fosse o stresse

contribuição:

- revisão do acordo feito sobre horário de saída

Atividades do dia 27:

Nos Jogos cooperativos 18 alunos consideraram bom, pelos seguintes motivos:

- $\quad$ adorei, é importante não perder o espírito das brincadeiras, e isso pode nos trazer alegrias, emoções e até inversão de papéis

- a possibilidade de através dos jogos distinguir cooperação e competição

- $\quad$ promove a interação

- aprendi a confiar mais nos amigos

- tenho dificuldade em disputar e participei. Isso está sendo inserido na minha vida a algum tempo

- $\quad$ aumenta o espírito de união

- foram úteis $\mathrm{p} /$ o projeto e me fizeram refletir

- contribuiu p/ nova visão e aprendizagem a respeito dos jogos, resgate do lúdico

- consolidou pactos de confiança no grupo

- "o importante é competir. Cooperar é fundamental" F.Brotto

- o grupo conseguiu refletir sobre a idéia de cooperação e as necessidades de uma açào cooperativa (segurança, planejamento, atenção)

- $\quad$ interação, companheirismo, respeito, divertido, reflexivo, adorei.

- Grande aprendizado

As contribuições:

- poderia ter mais jogos, faltou tempo

- ampliar esta atividade

três alunos consideraram razoável, pelos seguintes motivos:

- $\quad$ talvez por já ter feito um curso c/ o Fábio Brotto

- algumas atividades (futpar) podem oferecer riscos aos fisicamente mais frágeis um aluno considerou excelente, pois:

- $\quad$ prática educativa de reflexão/colaboração/entrosamento de forma prazerosa

na Educação ao ar livre, foram 21 bons, pelos motivos:

- $\quad$ aprendizado, partilha, emoções,

- $\quad$ se desse prá ter mais um dia desses

- a seqüência toda para levar a harmonia e confiança no grupo

- $\quad$ ajuda na aquisição de conhecimento, é mais significativo 
- a proposta é boa, mas a queda do Caixeta deveria ter sido mais discutida pelo grupo

- vivenciar as atividades foi ótimo

- $\quad$ conhecer e entender essa atividade nova por aqui

- contribuiu p/ nova visão e aprendizagem a respeito dos jogos, resgate do lúdico, promoveu integração

- contato com a natureza

- $\quad$ possibilidade de aplicação, amadurecimento e envolvimento do grupo

- maravilhoso, houve muita harmonia com o grupo

- fechamento com chave de ouro

- $\quad$ muitíssimo proveitosa apesar do calor e indisposição física

- $\quad$ foi o ponto alto para mim, as atividades foram muito interessantes

- o exercício de buscar solucionar problemas de forma coletiva para situações imediatas, afinou a confiança do grupo

- $\quad$ adorei todas as atividades, a confiança, escutar o colega, compartilhar emoções e até vencer barreiras

contribuições:

- faltou um pouco mais sobre questões pedagógicas

- $\quad$ faltou fazer amarração com o curso todo (?)

um excelente, pelos motivos: aprendizado descontraído

contribuições: cada grupo escolher uma brincadeira e apresentá-la posteriormente, elaborar um guia de campo coletivo e um manual de jogos cooperativos com a contribuição de cada aluno como tarefa de casa via RITS

atividade Solo, 14 consideraram bom, pelos motivos:

- consegui ficar sozinha, me observando, me sentindo, um desafio escrever a carta, estou ansiosa para lê-la daqui a 6 meses

- refleti sobre toda a viagem

- destaca-se a estratégia usada

- $\quad$ é tão simples e tão difícil de se fazer

- $\quad$ profícuo e gostoso

- $\quad$ tenho certeza que a proposta foi bem pensada pela coordenação, mas eu não cooperei me atrasando

- $\quad$ me encontrei, parei de fugir de alguém que precisava encontrar há 26 anos!

- Para podermos entender melhor nosso papel neste meio da EA

- Adorei a proposta da carta

- Oportunidade de reflexão, exercício do olhar, pacificação e harmonização interior

- Gosto de ficar sozinha de vez em quando, neste lugar fiquei só e não senti solidão

- $\quad$ Surpreendente exercício de reflexão

As contribuição foram que deveria haver mais tempo, o sininho (que avisava o término da atividade) tocou muito rápido 
Seis alunos consideraram razoável pelos motivos:

- $\quad$ cheguei atrasado, o baile não deveria ter ido até tarde da noite

- $\quad$ embora importante, não estava no clima de ficar sozinha

- $\quad$ após uma certa negociação e avaliação em relação ao atraso, pude no tempo que restou fazer uma reflexão pessoal muito interessante

- $\quad$ prejuízo pelo atraso

contribuição:

- $\quad$ considerar a surpresa (forró) e alterar o programa

mais ou menos 1

motivos:

- $\quad$ poderia ser melhor, não ter perdido tanto tempo para justificativas

ótimo 1

motivos:

- $\quad$ encontrei com alguém que não via a um tempão

quanto à Avaliação, 14 alunos consideraram boa, pelos motivos:

- discussões produtivas

- $\quad$ para relembrar tudo o que foi feito

- $\quad$ é preciso avaliar a parte e o todo para se perceber com mais clareza a ação

- exigência da análise

- $\quad$ momento de retroalimentação

- $\quad$ é bom mas não gosto de escrever

contribuições para esta atividade:

- $\quad$ tudo deve ser avaliado por mais chato que seja

- tentar encontrar questões pertinentes em todas as avaliações

- $\quad$ acho que vocês souberam avaliar e provocar nossas avaliações de forma muito legal e construtiva

- $\quad$ faz parte para podermos refletir e desenvolver um olhar e pensamento críticoreflexivo

razoável 3

motivos:

- cansativa e pouco espaço para escrever

- falta de estrutura (?)

- mais uma, só que documentada, avaliamos a todo momento, refletimos e ainda há alguns nós atados

- momento de aparar várias arestas grupo-coordenação e grupo-grupo

não resp. 4

ótima 1

motivos:

- a transferência de responsabilidade é uma estratégia positiva e não tecnocrática (?) 
Gostaríamos ainda de saber, com relação a todos os encontros presenciais do curso de especialização, se houve alguma atividade em especial que contribuiu para a sua percepção e aprendizagem sobre o meio ambiente? Qual foi?

- $\quad$ No encontro com o Marcos (escolher, identificar, conversar com uma árvore) 3

- $\quad$ Nenhuma em especial, elas se completam 7

- Montagem do totem 1

- Pequena trilha com Marcos 1

- O labirinto 3

- Houve uma evolução até chegar aqui, como uma pirâmide, as coisas acontecendo no tempo certo 1

- $\quad$ Não respondeu 2

- $\quad$ Aula sobre emancipação/participação e sobrevivência 2

- Nos trabalhos de intervenção 1

- A viagem foi fundamental 1

- Sempre saio dos encontros mais rico do que antes 1

- Todas mas também o horto e as experiências nele 1

- Solo 2

- $\quad$ Trilha de surpresas 1 